\title{
مقدهمة البحث
}

الحمد لله الكريه المنان، المتفضل على عبـاده بعظيه الآلاء، وجزيل

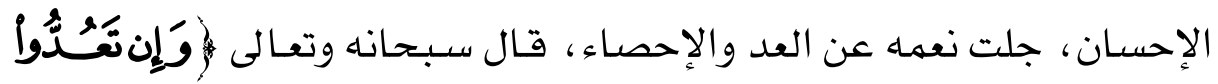

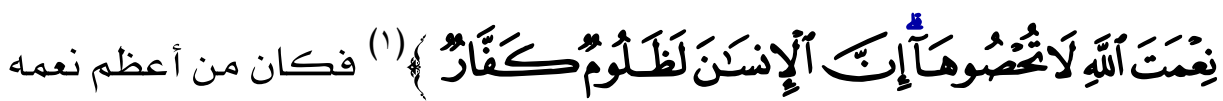

على عبـاده أن هـدى المـؤمنـين بـه إلى الإيهـان. والصـلاة والسـلام على سـيدنا

محمـد ، مـن ختمــت برسـالته الرسـالات ، وعلـى آلـه وصــحبه الـذين عـزروه

ونصسروهواتبعوا النور الذي أنزل عليـه، فكـانوا سـادة الدنيا وقادتهـا ، وأتحهـة

الهدى، ومصابيح الظلام.

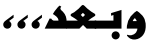

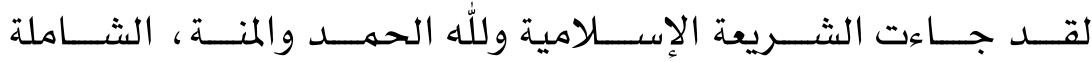

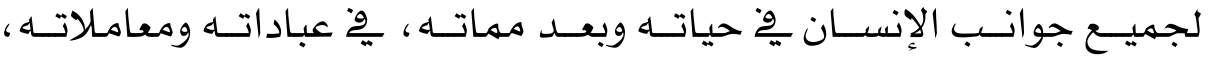

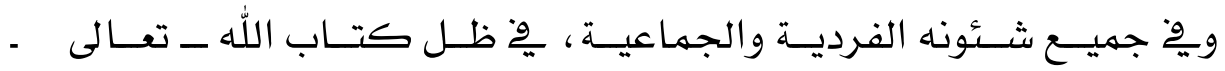

(1) سورة إبراهيم آية (ع ب).

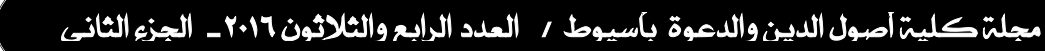




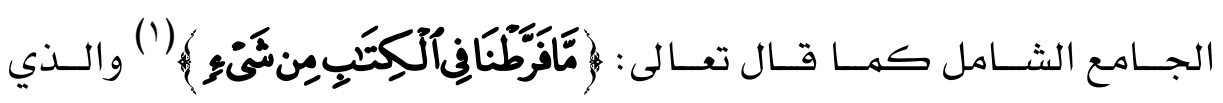

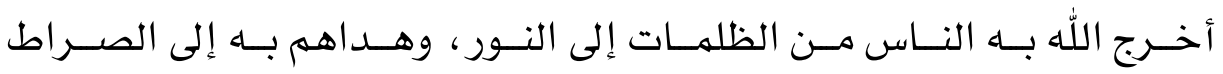

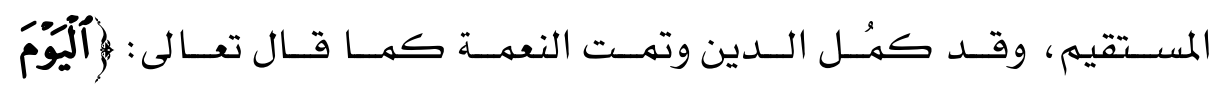

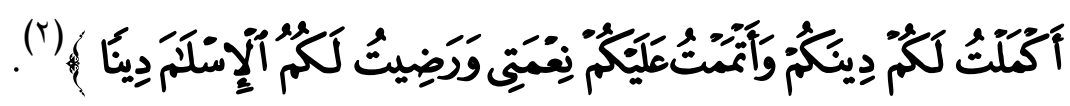

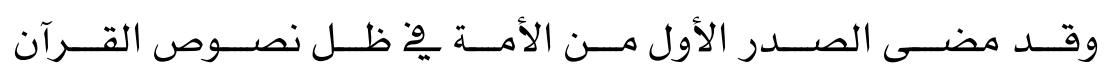

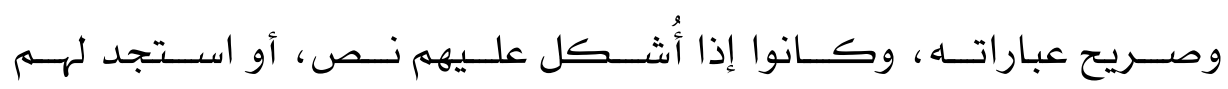

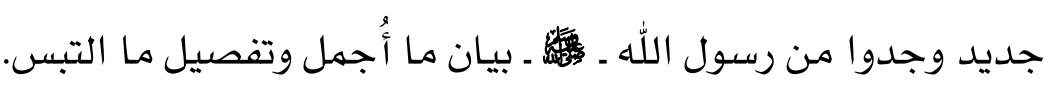

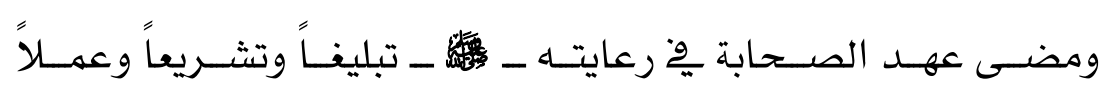
واتباعاً، حتى أتم الله عليهم النعهـة وختهم الرسـالة. وجــاء التـابعون علـى أثــر الســابقـين الأولـيـن واتبعـوهم بإحســان،

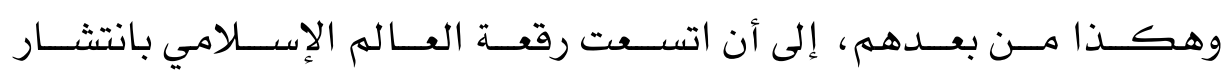
الإســـلام، فتجـــددت مـرافـق الحيــاة، وتعــددت صــورهـا ، فـرأى العلمــاء

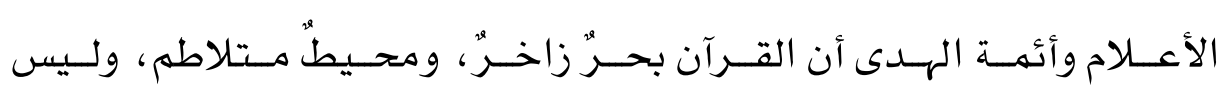
كـل ذي حاجـة يقــدر على تحصــيلها منـــهـ ، ولا كـل ذي علـم يحـيط بهـا

$$
\begin{aligned}
& \text { (1) سورة الأنعام آية ( (ب). } \\
& \text { (Y) سورة المائدة آية ( س ). }
\end{aligned}
$$




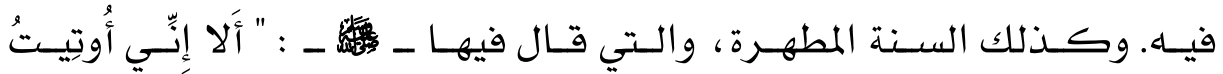

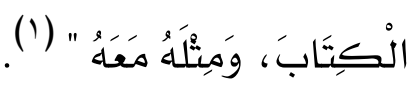

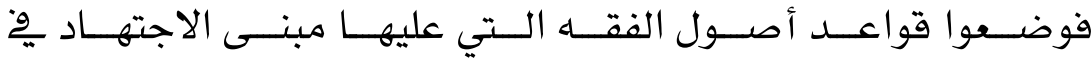

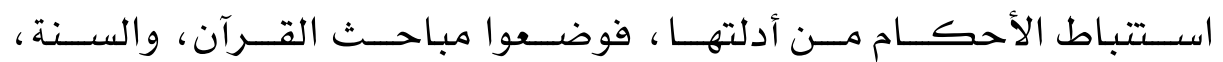

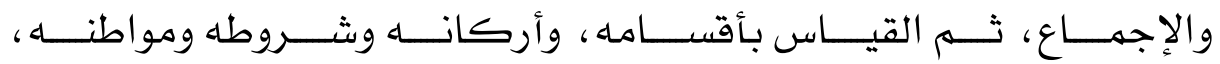

بأصوله وفروعه( (ك) ثم الأدلة المختلف وِّح حجيتها المقبول منها والمردود.

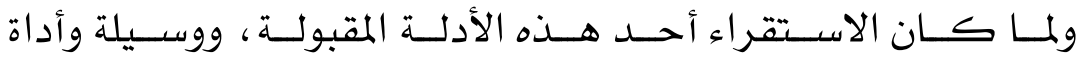

يسـتخدمها كـثير مـن العلهـاء لاسـيها الأصــوليين والفقهـاء والمنطقـيـين

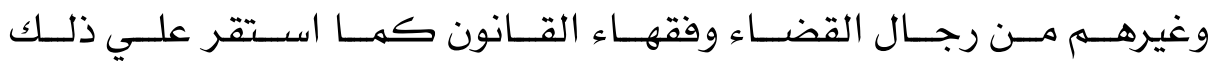

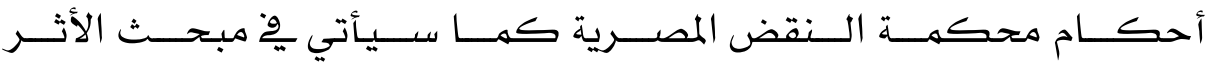

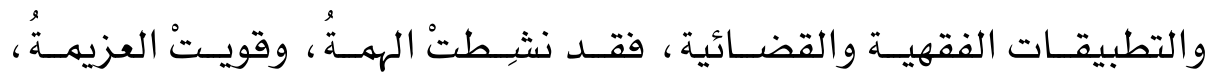

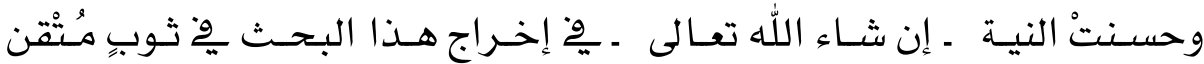

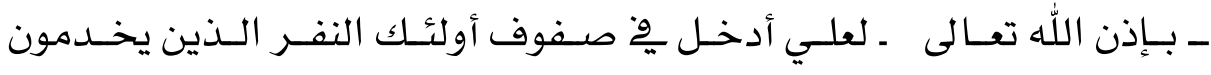

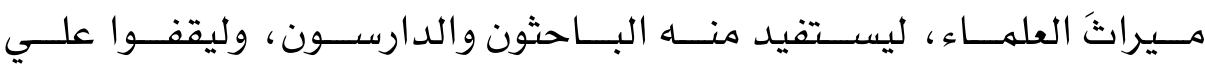

( ) أخرجه بهذا اللفظ: أبو داود في سننه، كتاب السنة، باب في لزوم السنة، حديث (ع ـ جـ) والإمام البغوي في شرح السنة، كتاب الإيمان، باب الاعتصام بالكتاب والسنة، حديث

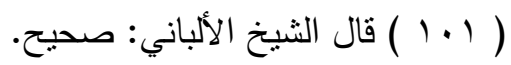

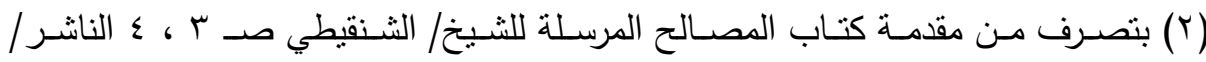

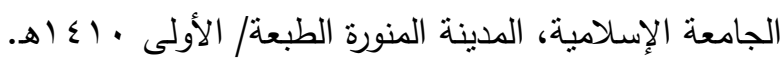




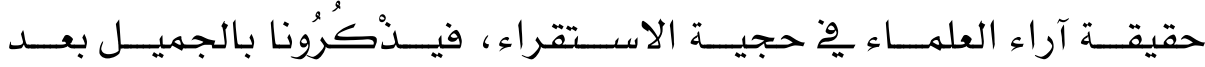

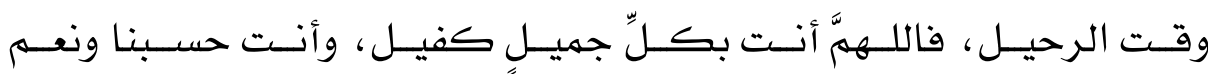

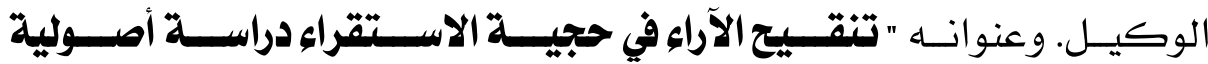
تطبيقية " توبة

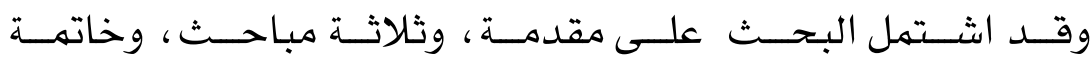
وبيان ذلك علي النحو التالي: أما المةدهة : فتشتتمل علي سبب اختيار الموضوع، وأهميته. وأما المباحث الثلاثة فهي: الهبــنْ الآهول : وِّ تعريف الاستقراء لغة واصطلاحاً. ويشتهل علي مطلبين:

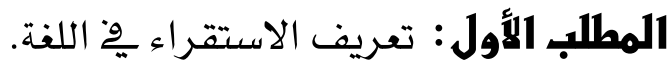
الهمالب 11:نانب : تعريف الاستقراء يخ الاصطلاح.

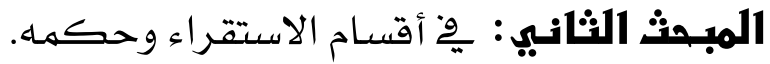
ويشتمل علي مطلبين:

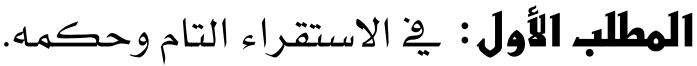

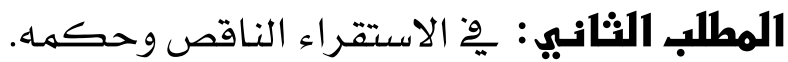

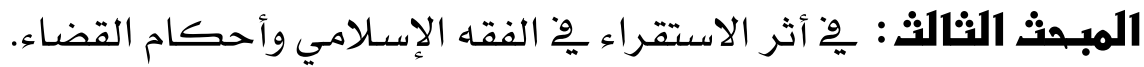




$$
\text { ويشتهل علي مطلبين: }
$$

الهطلب الأول : أثر الاستقراء يِّ الفقه الإسـلامي.

$$
\text { ويشتهل علي ثلاثة فروع: }
$$

الهُر عم الأول : أثر الاستقراء يِّ أقل الحيض وأكثره.

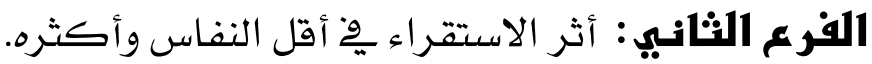

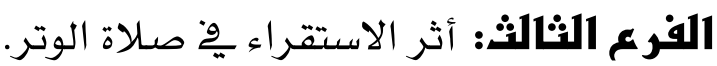

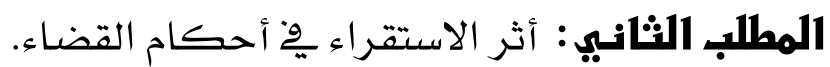
ويشتمل علي ثلاثة فروع:

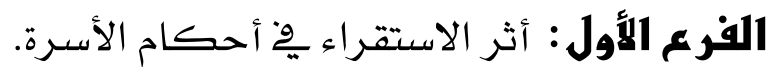

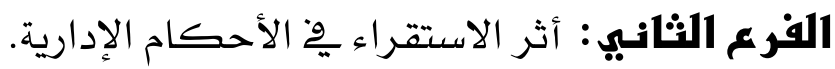

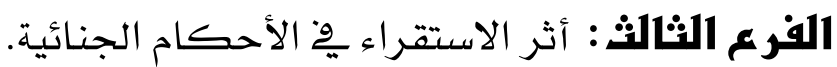

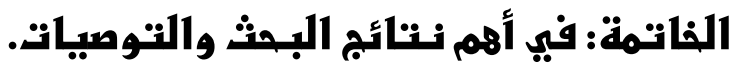

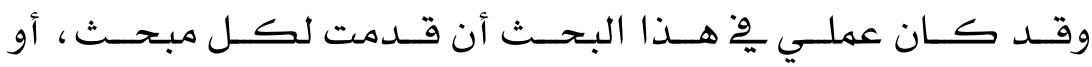
مطلـبِ، أو فـرعٍ مـن الفـروع يتعلـق بـه حتـى يتسـنى لـي تحريـر محـل النـزاع

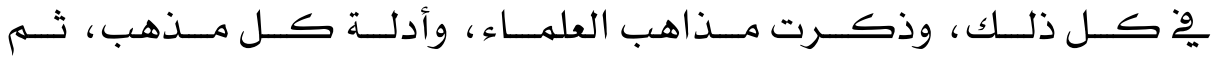




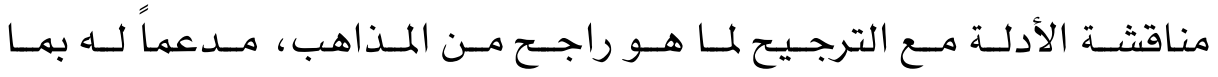
ذكــره العلهـاء مــن أسـبابِ لترجيحــه، مــع إســناد الأدلــة إلى أصــحابها ، وذكــر فـروعِ فقهيـة وأحكــامِ قضــائيةٍ لبيـان أثـر الاسـتقراء علـى سـبيل التمثيل لا على سبيل الحصر.

\section{اختيار الموضوع، وأهميتهـ}

\section{أولاً: 11بب افنتبار الموضو ع :}

إن سـبب اختيـارى لهـذا الموضــوع ورغبتـى الملحسـة للكتابـة فيـهـ هـو

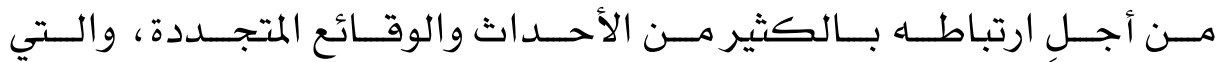

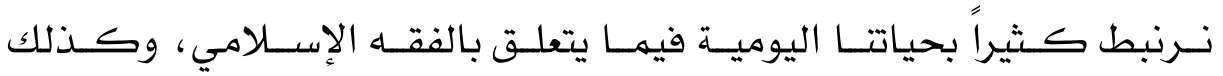

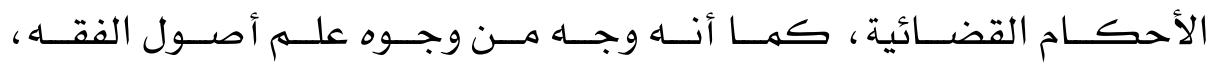
وجانـب مـن جوانبـهـ، وفيـهـ جـلاءً لكــير مـن المســائل المختلـف فيهـا ، وإن كـان سـبقنى الكـثير مـن البـاحثين إلا أنــني أردتُ أن يكــون لـيَّ معهـم نصـيبُ مـن الإضـافة، حـتي يـأتي مـن يكهـل بنيـان هـــه المسـألة الـتي أرى

\section{نَّ لها من الأهمية قدرٌ كبيرٌ. نانباً: أهمبينه :}

للاستقراء أهمية كبرى يُّ مناهـج البحوث العلمية بصـفة عامـة ، حيـث

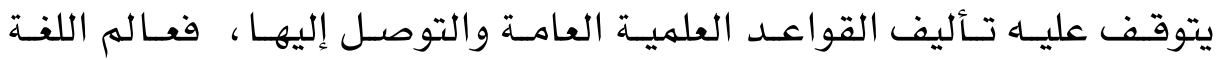


العربيـة لا يستطيع أن يُعطـي قواعـد عامـة يوْ اللفـة مـا له يسـتقرئ ويـدرس مختلف المفردات والجمل يِّ شتى استعمالات العرب اللفظية. وعـاله الفيزيـاء لا يسـتطيع أن يتوصـل إلـي قواعـد علـم الفيزيـاء حـول الظاهرة الطبيعية ما له يدرس مختلف جزئيات كل ظاهرة من تلك الظواهر التي يحاول إعطاء قواعد عامة لها. وهكذا يِّ كل علمه من العلوم الأخرى، فالاستقراء هو الذي يزودنا بالقواعد العامة التي نستعملها بِّ التطبيقات العلهية.

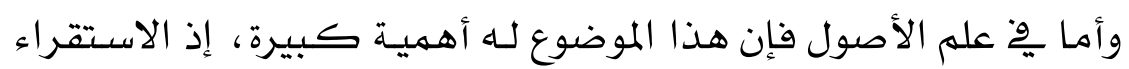

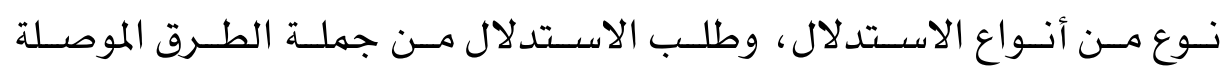

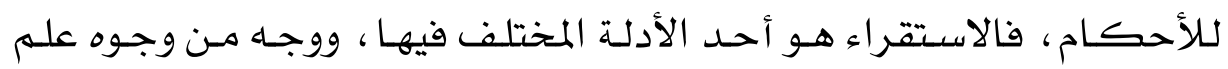

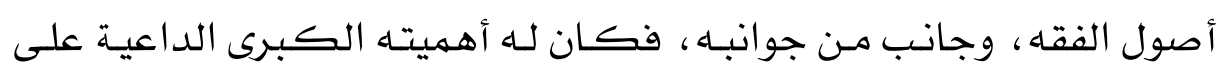

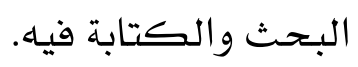

وأخيراً أتوجه إلى الله بالشكر وأسـأله العفو لما وقع مـن تقصير وخلل

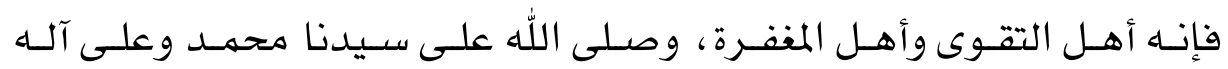
وصحباه وسلهم.

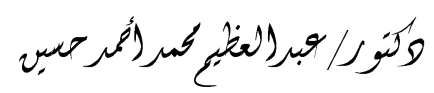

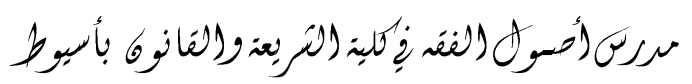




\section{المبحث الأول}

\section{تعريف الاستقراء لغة واصطلاحا}

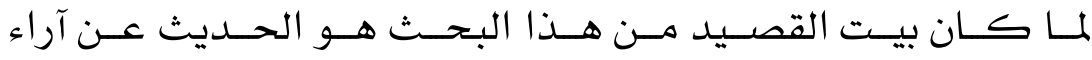

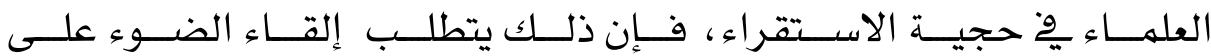

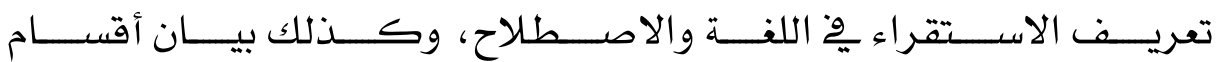

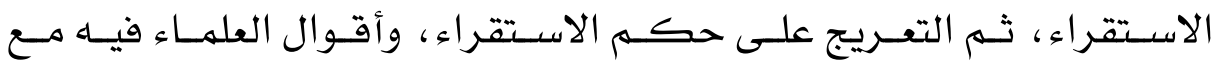

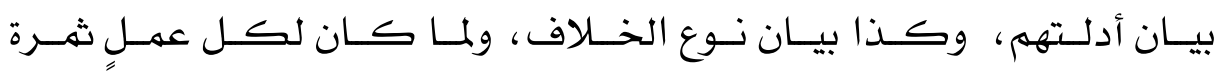

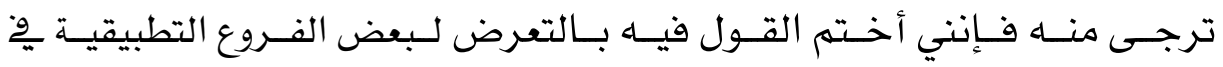
الفقهاه والقضاء لبيان ثمـرة الخـلاف بين العلماء. والحديث عن المبحث الأول: يكون من خلال مطلبين: 


\section{الاططلب الأول}

\section{تعريف الاستقرايء في اللغة}

الاســتقرائ لغــة: التتبـع، والتحــري، أي: تتبـع الجزئيــات للوصــول

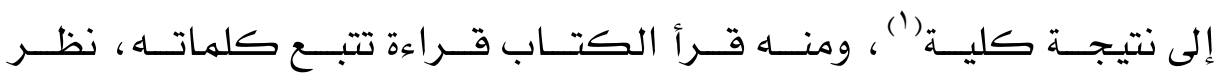

$$
\text { ونطق بها أو له ينطق (r) }
$$

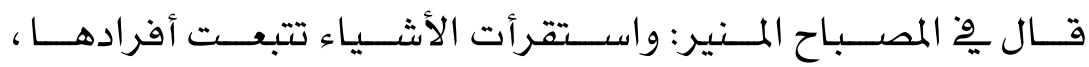

$$
\text { لمعرفة أحوالها وخواصها (َ). }
$$

وعلى ضـوء مـا ســق فـإن الاسـتقراء لغــة مـأخوذ مـن قـولهم: قـرأت

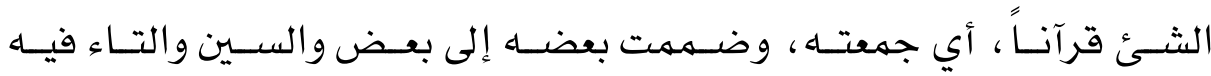

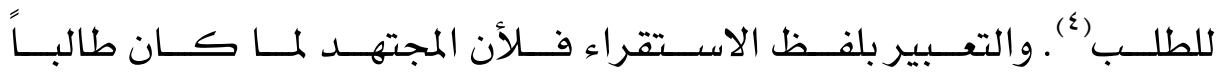

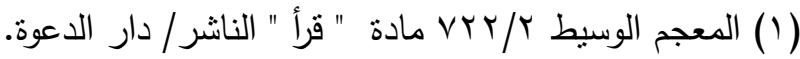

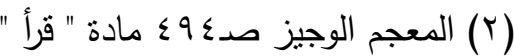

المصباح المنير في غريب الثرح الكبير للحموي r/ / . .

ينظر المراجع السابقة، ومختار الصحاح للرازي صـ 9 ؟ ب الناشر / المكتبة العصرية -

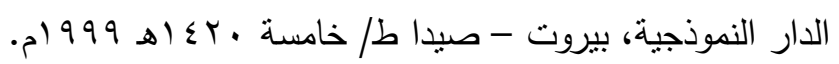




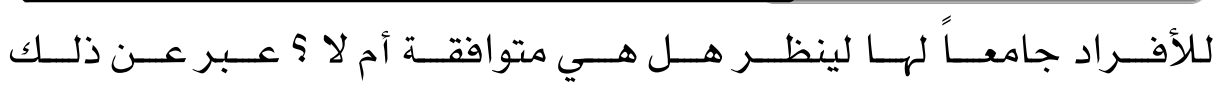
بالاستقراء،

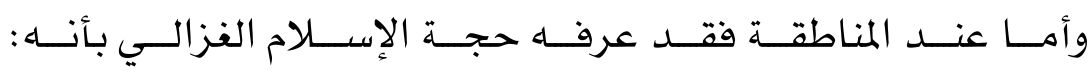

عبـارة عـن تصـفح أمسـور جزئيسة لـيحكم بحكههـا على أمـر يشـهل تلـك

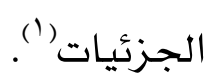

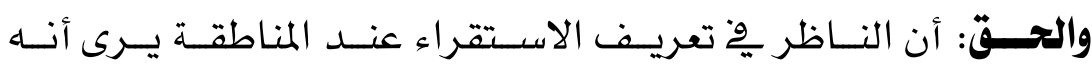

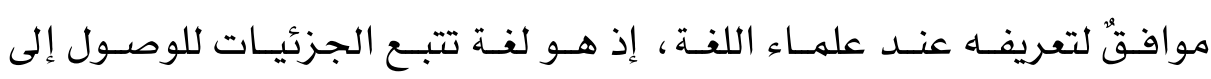

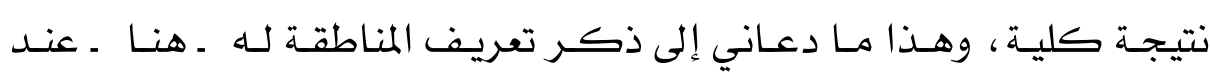
الحديث عن التعريف اللغوي.

(1) ينظر : محك النظر في المنطق للغزالي صـ وبr تحقيق/ أحمد فريد المزيدي الناشر/ دار الكتب العلمية، بيروت - لبنان، المختار من شرح السلم صـ ـ 7. 


\section{المطالب الثنانـي}

\section{تعربف 11استقراء في 1لاصطلام \\ عُرف الاستقرائ في الاصطلاح بعدة تعريفاتِ منها:}

1

فهـو : عبـارة عـن تصـفح أمـور جزئيـة لـيحكم بحكمهـا على أمـر يشـمل تلك الجزئيات (')

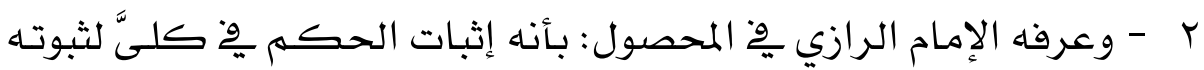

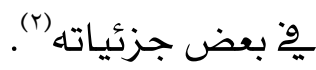

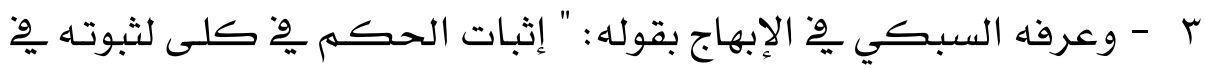

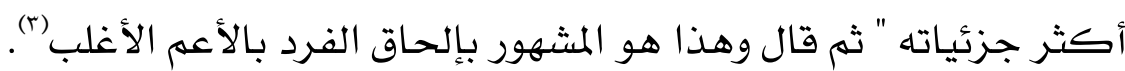
وهنـاك تعريفـات كثيرة للاسـتقراء لهم أتعـرض لها خشـية الإطالـة،

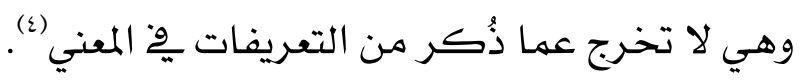

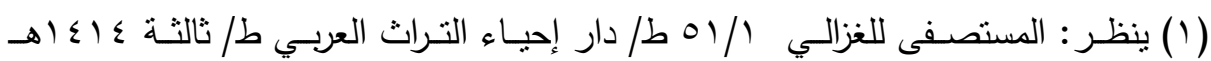
. 999

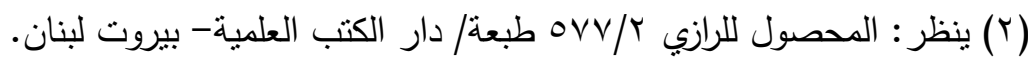

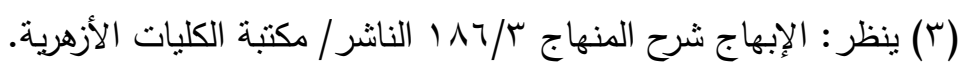

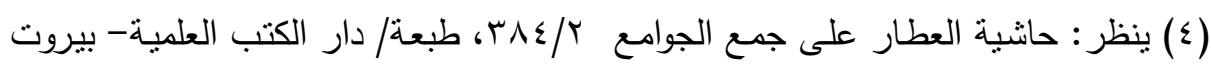

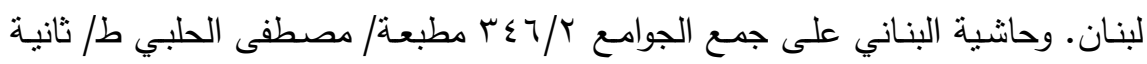

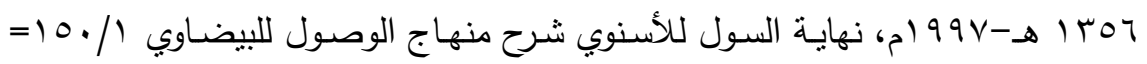


وهــذه التعريفـات هـي الـتي تُعـبر عـن الاســتراء ـوْ شــكله العـام

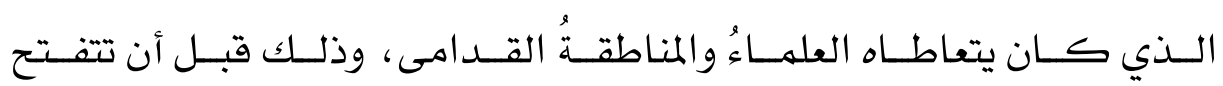

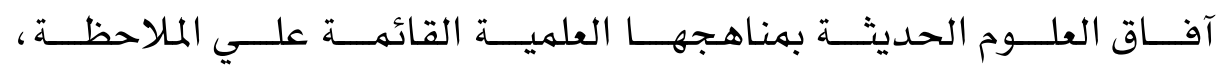

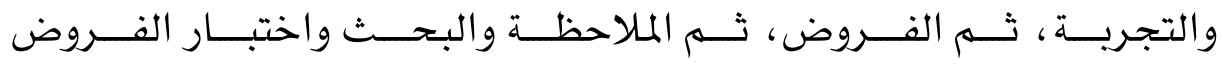
للوصــول إلـي القــوانـين العلميــة الماديــة ، ولــذلك عَـرَّف هــؤلاء الاســتقراء بتعريفـات أخـرى تعـبر عـن المرحلـة الجديــدة الـتي وصـلوا إليهـا بصـفته

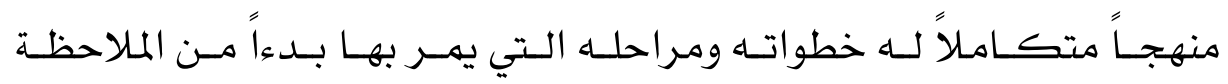

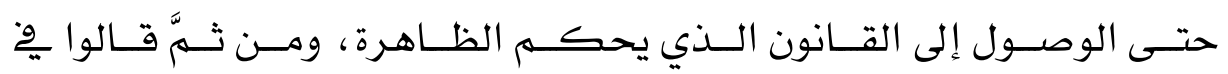

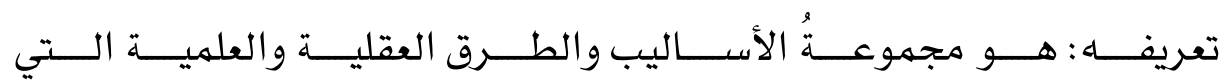

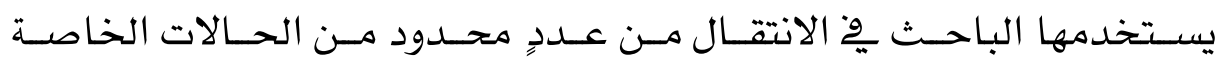

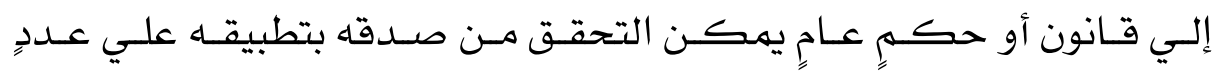
لا حصــر لــه مـن الحــالات الأخــرى الـتي تشـترك مــع الأول فِ خواصـها

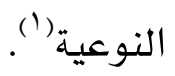

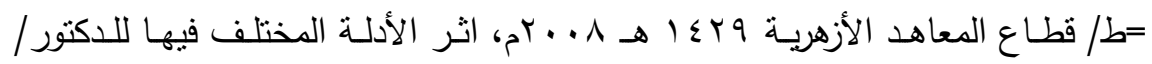
مصطفى ديب البُغَا صدمء 7 ط/ دار العلوم الإنسانية- دمشق حليوني. (1) ينظر : منتدى العقلانيين العرب ( www . arab- rationalists.net ) 


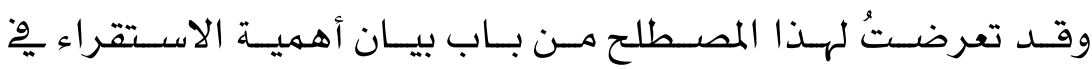

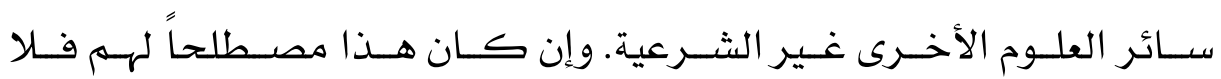
يعارض مصطلحات الفقهاء والأصوليين إذ لا مشاحة يُّ الاصطلاح،

وبعـد عـرض مـا ســق مـن تعريفــاتٍ للاسـتقراء يتـبـين أن تعريفــهـ

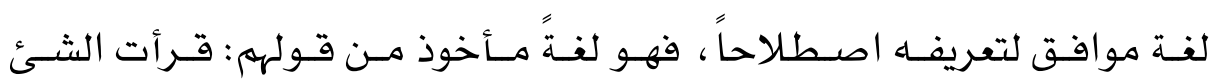

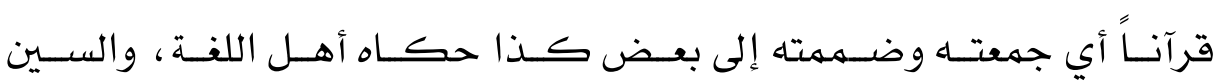

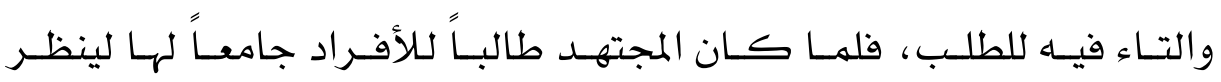

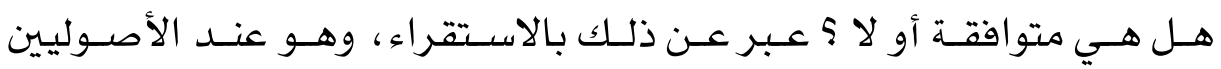

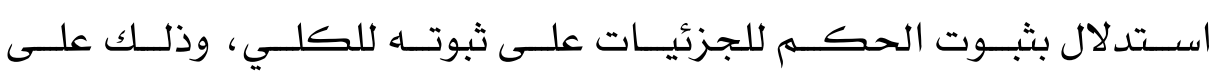

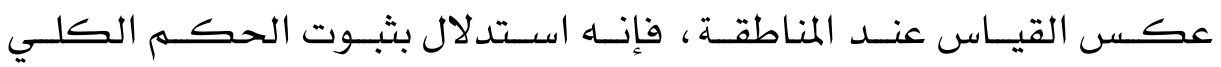

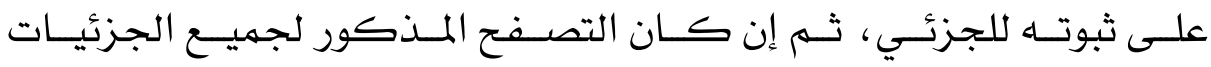

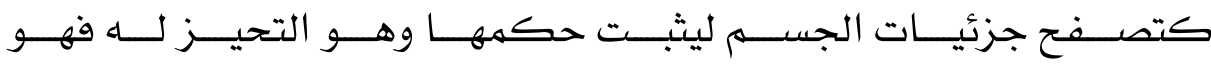

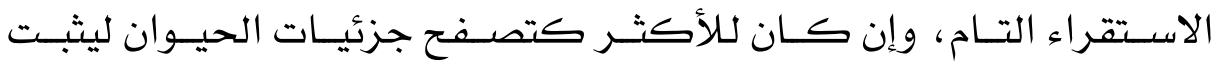

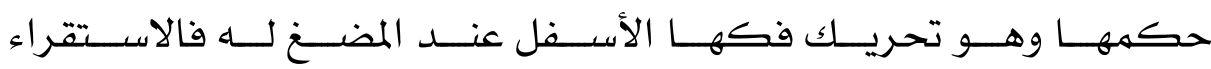

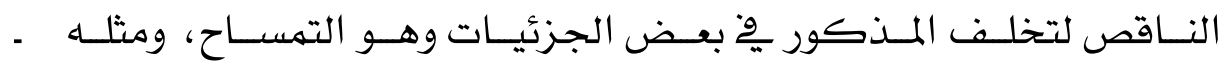

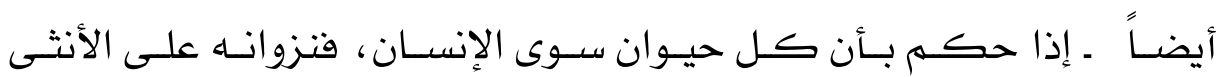




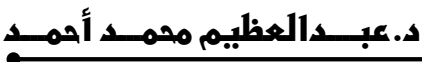

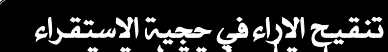

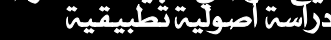

مـن وراء بـلال تقابـل الـوجهين لهم يـأمن أن يكــون سـفـاد القنفــد وهــو مـن

الحيوانات على المقابلة لكنـه له يشاهده (').

والحــقة: أن الاسـتقراء عنــد المنـاطقـة لا بـدَّ فيـهـ مـن حصــر الكلـي

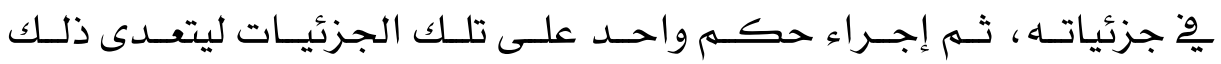
الحككـم إلى ذلــك الكلـي، فـإن كــان ذلـك الحصـر قطعيـاً بـأن يتحقـق

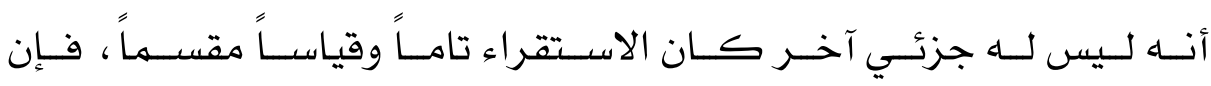

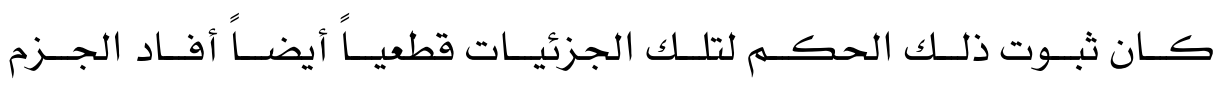

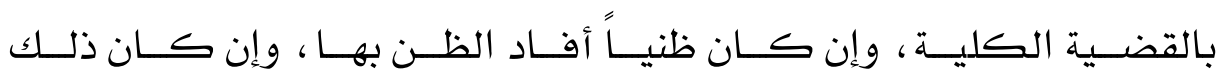

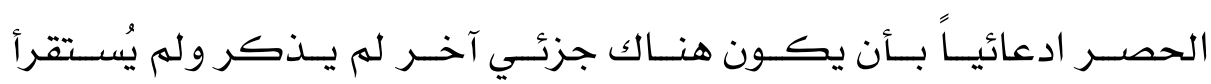
حالـه لكنـه اذَّعـى بحسـب الظـاهـر أن جزئياتـه مـا ذكــر فقط أفـاد ظنـاً

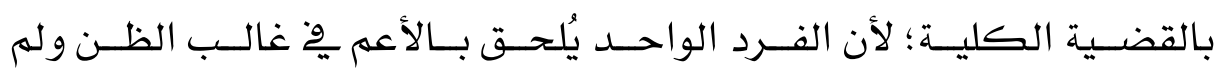

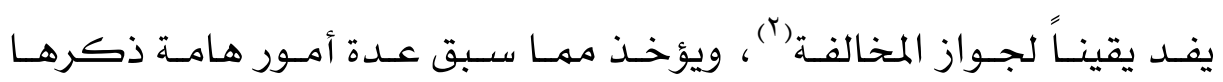
بعض الأصوليين وهى:

(1) ينظـر : تهافـت الفلاسـفة للغزالـي صــب تحقيـق: الدكتور سـليمان دنيـا الناشـر / دار المعارف، القاهرة - مصر ط/ سادسة، معيار العلم في فن المنطق للغزالي صـ به

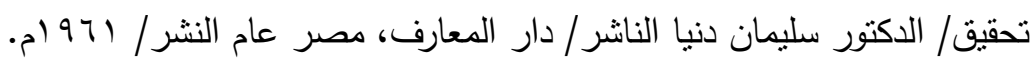
(r) ينظر : تقريرات الثربيني على حاشية العطار على جمع الجوامع rمo/r. 
أولاً: أن الاستقراء عند الأصوليين دائماً ناقص عند المناطقة)؛ لأن التام مرجعه إلى قياس مقسم كها يقال العدد إما زوج وإما فرد ، وكل زوج يعده الواحد وكل فرد يعده الواحد، فكل عدد يعده الواحد، وهذا القياس

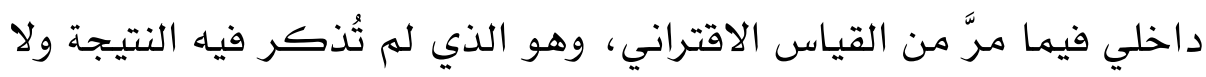

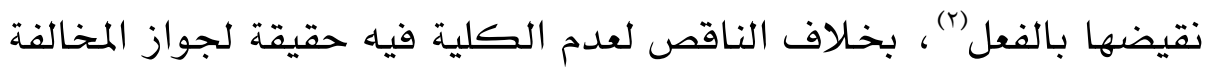

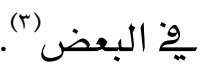

ثانباً: أن المقصـود بالـذات بالاسـتقراء عنـــ المناطقـة الحكـم على الكلي بخلافه عند الأصوليين فإنه الحكـم على الجزئي لتعلق غرضهم بأحكـام الجزئيات.

ثنالثناً: أن الأصـوليـين لا حاجـة بهـم إلى الاسـتقراء التـام عنـــ المناطقة؛ لأنـــ مبني على علم ثبوت الحكم مِّجميع الجزئيات، والأصوليون إنما يحتاجون

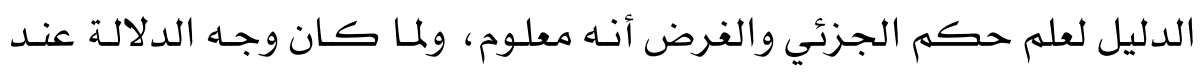

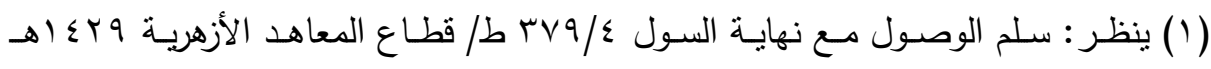

$$
\text { ק }
$$

(r) متل: كل جسم مؤلف وكل مؤلف حادث فيلزم منه أن كل جسم حادث، وكل نبيذ مسكر

$$
\text { وكل مسكر حرام فيلزم منه أن كل نبيذ حرام وهكذا. }
$$

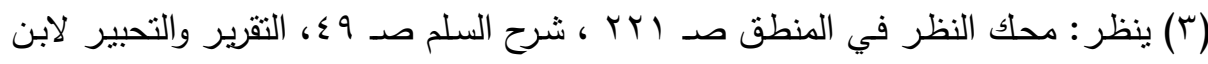

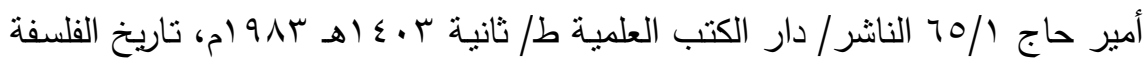

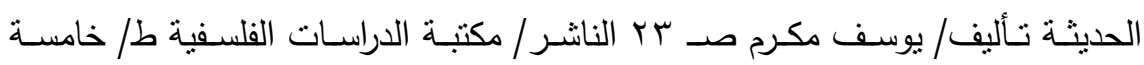


المناطقة لا بدَّ وأن يكون لزوماً عقلياً كـان الاسـتقراء سـواء أكسان للجميع

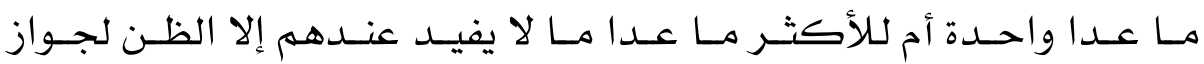
المخالفة ، بخلاف الأصوليين فإن وجه الدلالة عندهم أعمى من العقلي والعادي كما يوْ المتواتر حيث قالوا إنه يفيد القطع، فكـان الاستقراء التـام بهعنـاه

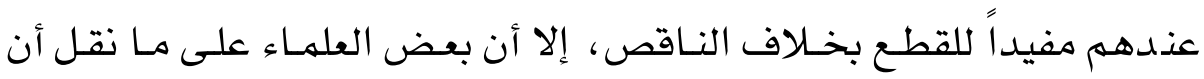
الناقص عند المناطقة هو ما جهل فيه حال جزئي واحد فقط حقيقة أو ادعـاء بخلافه عند الأصوليين فإنه يكفي قضـاء العادة بإلحاق ما بقي بها ثبت فيـه الحكم قطعاً أو ظناً (1).

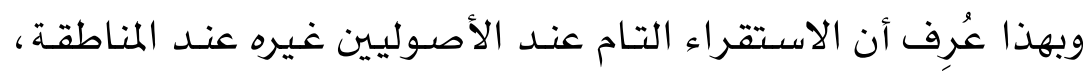
فيحمل هنا على أنها تصفح جزئيات الجسـم ما عدا صورة النزاع، فالاستقراء

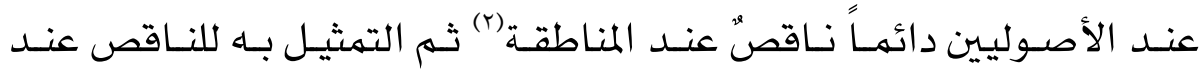
الأصوليين يحتاج إلى أن يكون بعض الحيوانات غير التمسـاح له يعله حالـه

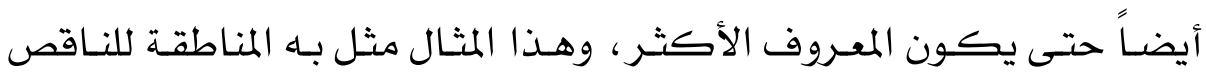

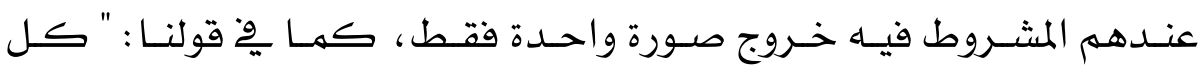

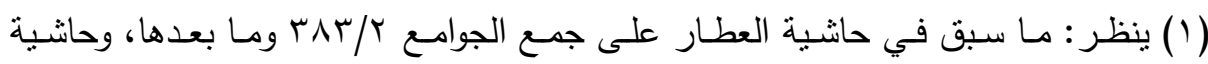

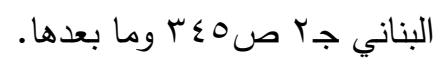

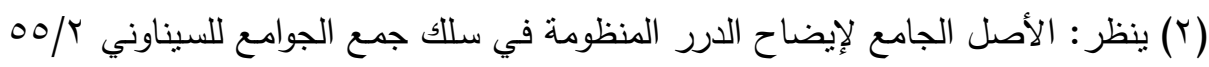

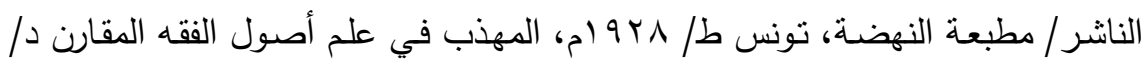

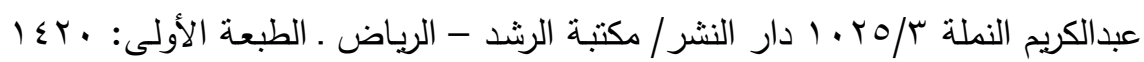
هـ 


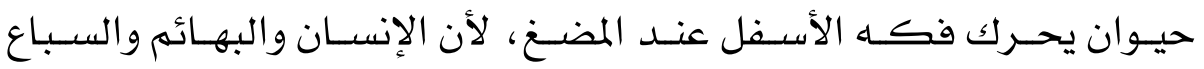

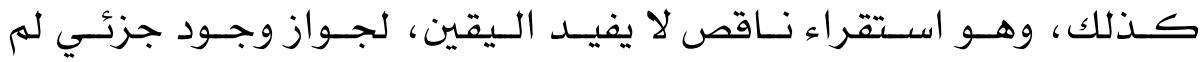

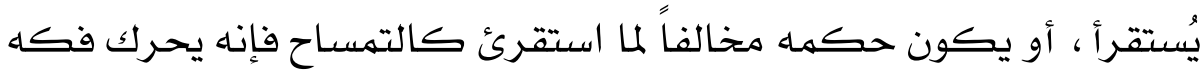
الأعلى عند المضـغن، وككالقنفــ فـإن سـفاده علي الأنثي يكـون علي المقابلة كالإنسان مخالفـاً بـذلك سـائر الحيوانـات، فيككون المـراد عنـد الأصسوليـين

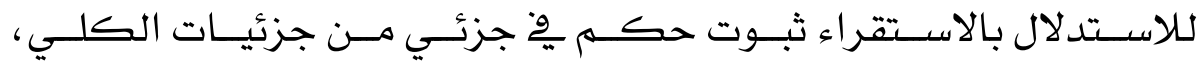
فالأصوليون يبحثون الاستقراء الناقص عند المناطقة. قـال الثـيخ حسـن العطسار : " .... ويعلهم أيضـاً أن المقصـود بالـذات بالاسـتقراء

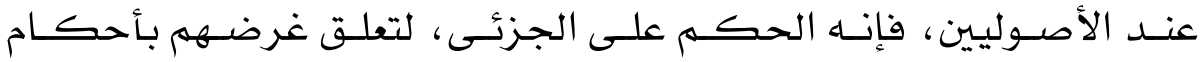
الجزئيـات، ومن هنـا يعله أنه لا حاجة بهم إلى الاسـتقراء التـام عنـد المناطقة؛ لأنـه مبنـى على علهم ثبـوت الحكـم في جميـع الجزئيـات، والأصـوليون إنهـا

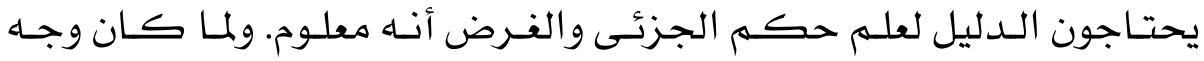

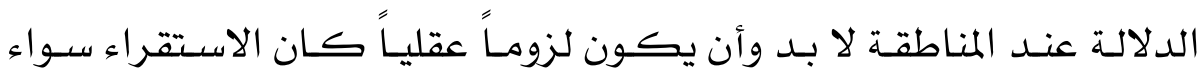
كان للجميع ما عدا واحدة أو للأكثر ما عـدا مـا لا يفيـد عنـدهم إلا الظن لجواز المخالفة.

بخلاف الأصـوليين فيان وجـاء الدلالـة عندهـم أعـم مـن العقلى والعـادى كما فى المتواتر حيث قالوا إنـه يفيـد القطـع فكـان الاسـتقراء التـام بهعنـاه عندهم مفيداً للقطع بخـلاف الناقص.

ثـم قـال الثــيخ العطـار: " فتحصــل أن التـام والنـاقص عنـــ المنـاطقـة

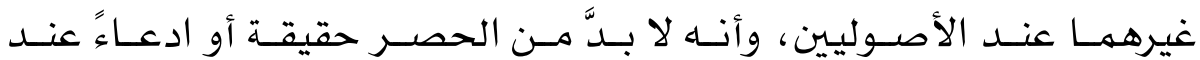




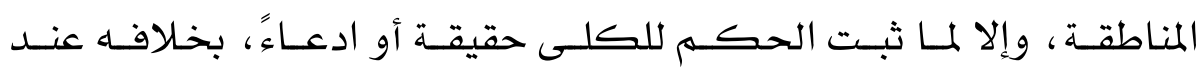
الأصوليين فإنـا يكفى قضـاء العـادة بإلحـاق مـا بقى بهـا ثبـت فيـه الحكـم قطعاً أو ظناً.

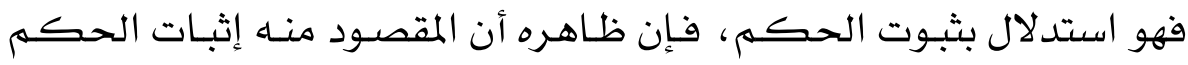
للكلى فى ذاتـه، فيحمهل على أن إثبـات الحكـم لـه لينتقـل منـهـ إلى إثباتـه

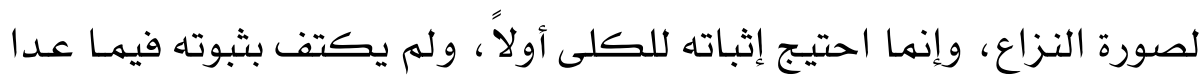

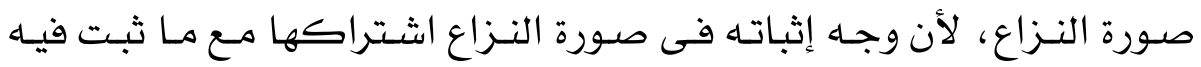
الحكم فى أمر كلى بناء على اتحاد حكم الجنس أو النوع الواحد. والحاصل أن هنا حكهـين، حكـم على الكلى، وسـببـاء ثبوتـه فى جميع

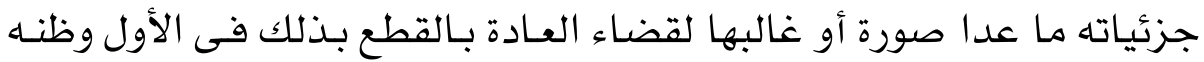

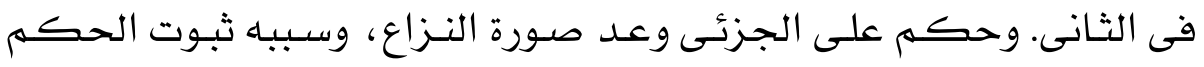
للكلى بطريقة المتقدم أ.هـ" (1). 


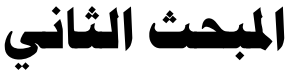

\section{أقسام الاستقـراء وحكمهه}

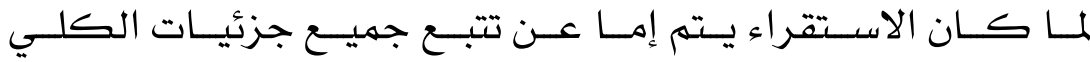

المطلـوب معرفـة حكهــه، ، كمـا لـو أرادت جامعـة الأزهــر أن تعـرف هـل

مـن بــين الطلبـة الدارســين بهـا طلابـاً أفريقيـين أو لاء فإنهـا تسـتقرئ كـل

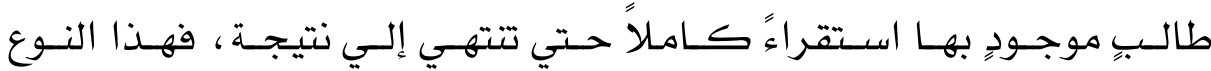
هـن الاســقـراء الكامـل الشــامل لجميـع جزئيـات الكلـي والانتهـاء إلـي نتيجـة منـه يسمى بـ"الاستقراء التام".

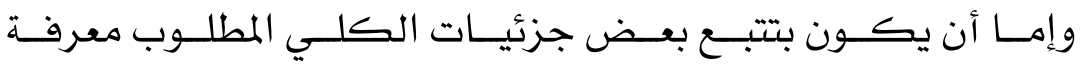

حكهــه، كهــا لـو أراد الفقيـه معرفـة نـوع الـدم الـذي تـراه الحـامـل، هــل

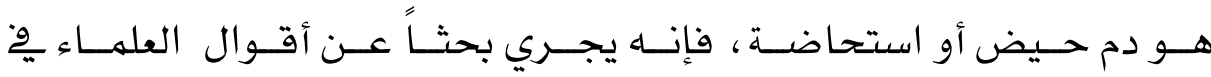
هـذه المســألة لمعرفـة رأيهـم مُّهـ ذلـك، أو أراد عـالم الكيميـاء معرفـة مـدى

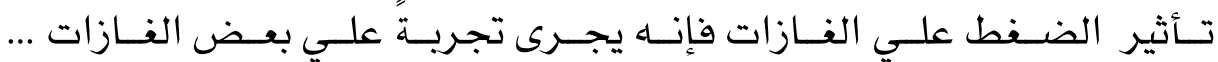
وهـكـذا ، وهــذا يســهى بـــالاستقراء النـاقص ·. وبيــان ذلـك علــي النـحــو

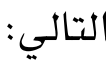
الامطلب الأول: في الاستقراء التام وحكمه. الاطلب الثُاني: في الاستقراء الناقص وحكمه. 


\section{الاططلب الأول}

\section{الاستقراي التام وحككمه}

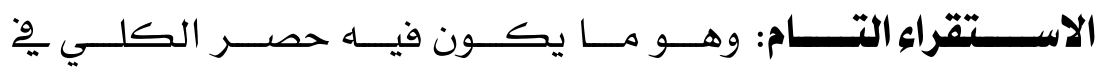

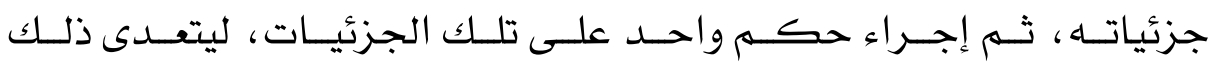
الحككـم إلى ذلــك الكلـي._أو هـــو تصــفـح جميــع الجزئيــات لـيحكم بحكهمها علـى كلـى يشــملها مثـل قولنـا : كـل إنســان نـاطق (') وكــذا

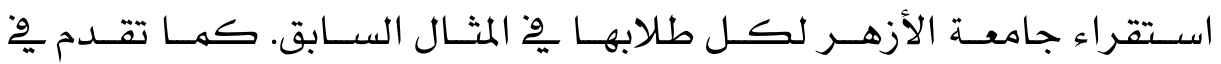

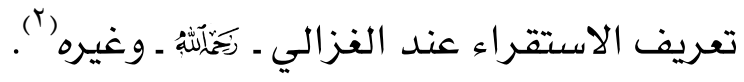

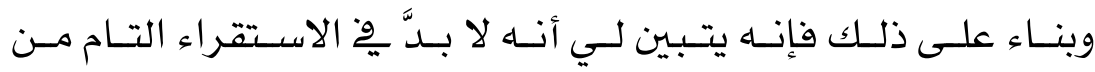

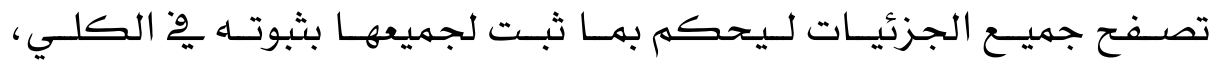
فهـو تتبـعْ لكـل الجزئيــات، أي نـاظهم لأشـتات صــورهـا إلا صــورة النــزاع للوصــول إلى حكــم تلـك الصــورة، فيـكــون المــراد بالاســتـراء التــام تتبــع

(1) ينظر : دراسات أصسولية في القرآن الكريم لأستاذي الدكتور / محمد إبراهيم الحفناوي صـ

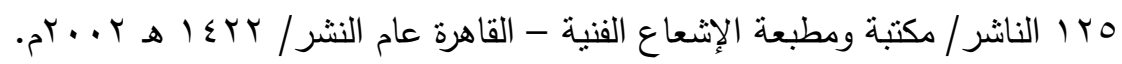
(Y) بنظر : المستصفى للغزالي / / / (Y) 
جميــع الجـزئيــات للوصـــول إلى حكـــم قاعــــة كليــة ، وذلـــك بثبــوت

الحكم يو جميع الجزئيات على ثبوته للقاعدة الكلية (').

\section{هكم 1لا1نتنقراء 11لتنام}

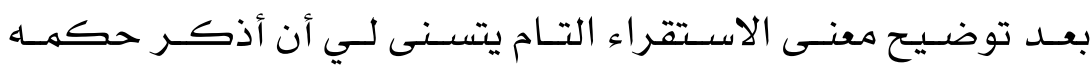

حتى تتم الفائدة المرجوة من البحث فأقول وبالله التوفيق:

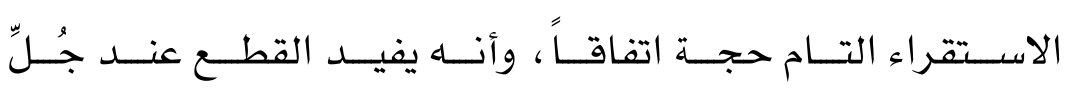

علماء الأصول وغيرهـم (r).

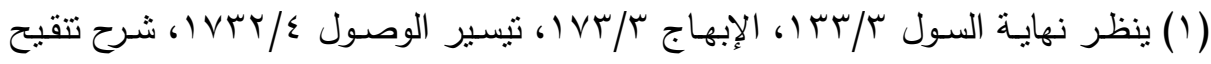
الفصول للقرافي صـ ^^ء؟ تحقيق/طه عبد الرؤوف سعد الناشر/شركة الطباعة الفنية

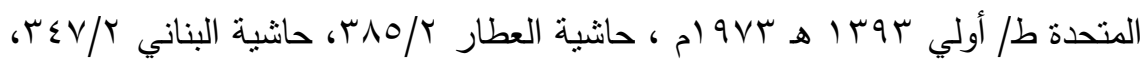
الموافقات للشاطبي / / • ا تحقيق/ أبو عبيدة مشهور بن حسن آل سلمان الناشر / دار

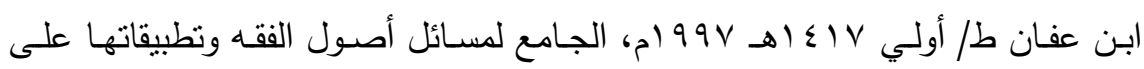

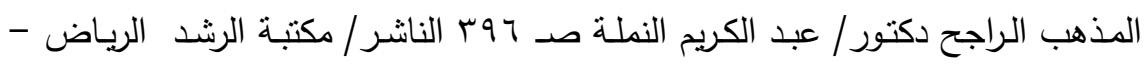

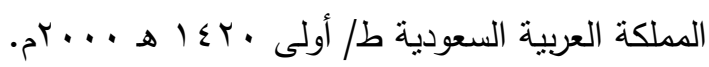

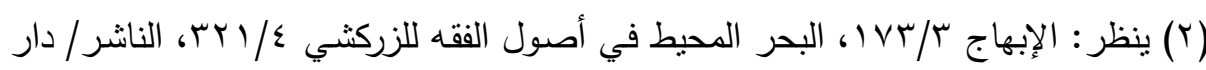

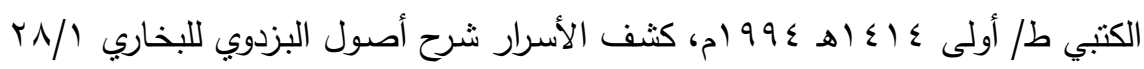

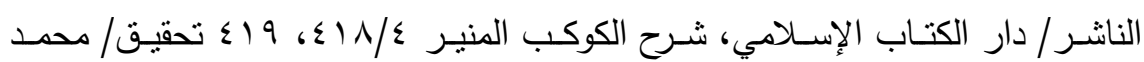

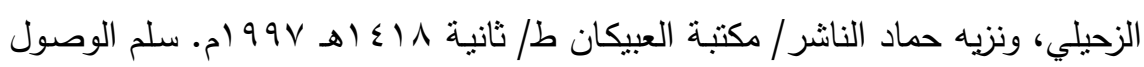
.rVV/s 


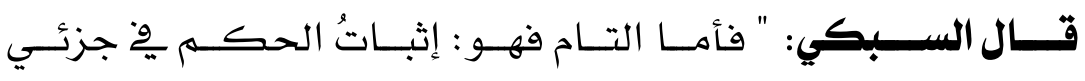

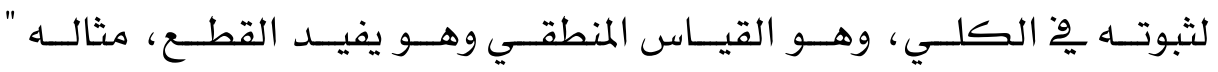
كـل جســم متحيـز " فإنـا اسـتقرينا جميــع جزئيـات الجســم فوجــنـاهـا

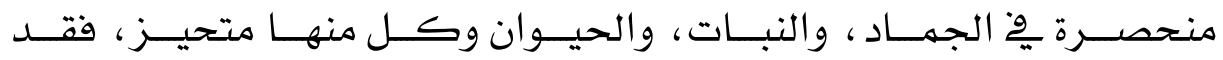

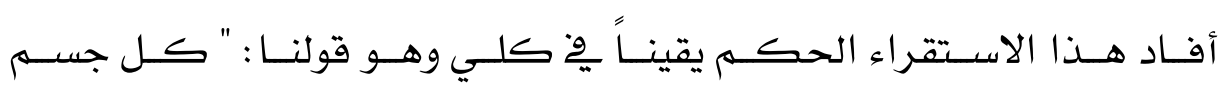

$$
\text { متحيز " بوجود التحيز بِ جميع جزئياته "(1). }
$$

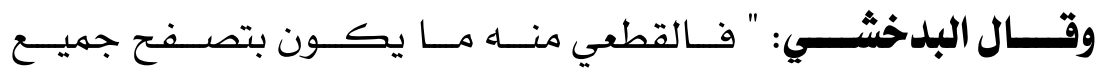

الجزئيـات ويسـهى قياسـاً مقسـهـاً "(r) وهـو أيضــاً مـا قالـه صـاحب تيسـير

$$
\text { التحرير وغيره }
$$

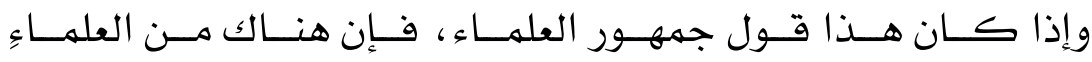

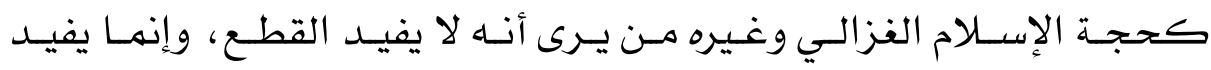

الظـن لاحتهــال عـدم احتوائهـ جميـع صـور النـزاع، ومخالفـة تلـك الصــورة

$$
\text { لغيرها علي بعد (ع). }
$$

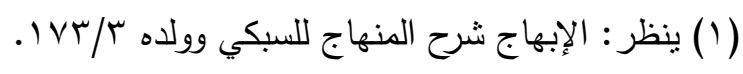

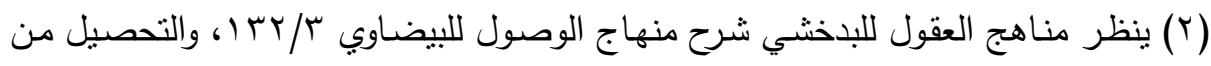

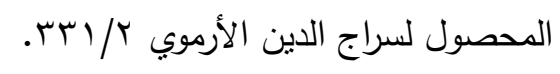

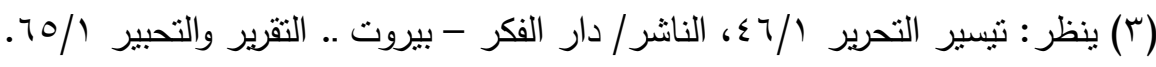

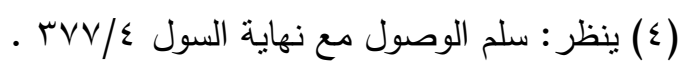




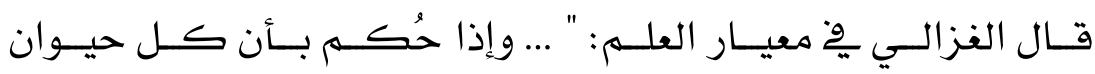

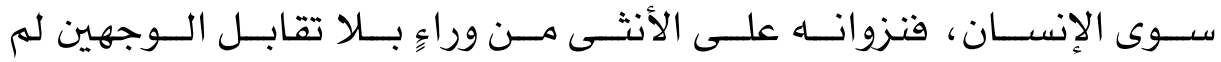

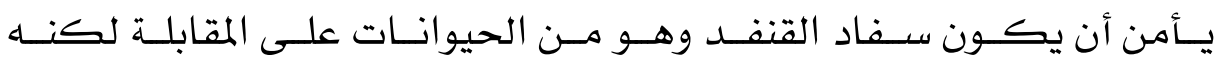
لم يشـاهده، فِإذن حصـل مـن هــذا أن الاسـتقراء التـام يفيـــ الظـن، فـإذن

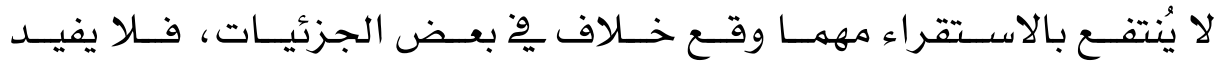
الاستقراء علماً كلياً بثبوت الحكم للمعنى الجامع للجزئيات "(1).

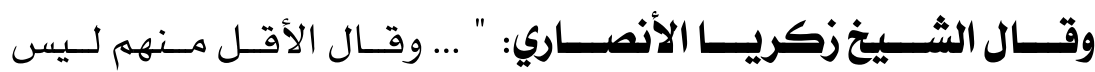
بقطعـي لاحتمـال مخالفـة تلــك الصــورة لفيرهـا(r) وهـو مـا ذكــره الثـيخ العطار وِّ حاشيته أيضاً (ب).

\section{بجاب عن ذلك من قبل الجمهور:}

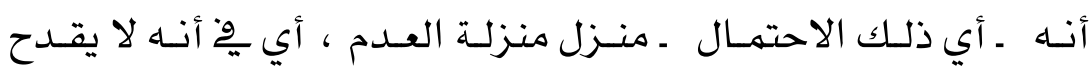

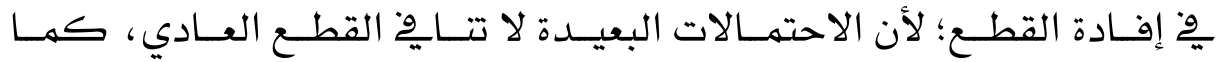

(1) ينظر : معيار العلم في فن المنطق صـ بآ ا.

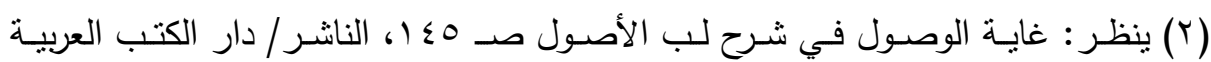

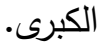

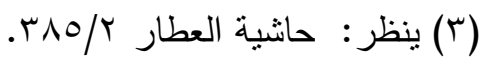




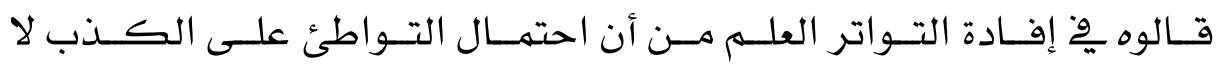

ينايٌٍ إفادته العلى الضروري (').

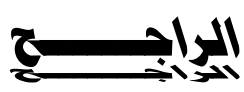

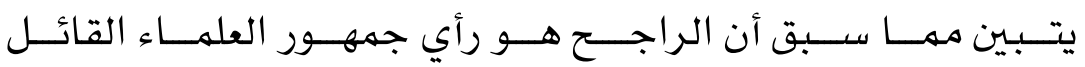

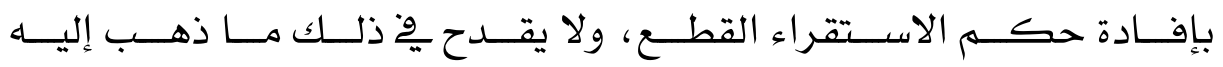
الغزالــي وغـيره مــن احتمـــال مخالفــة تلــك الصـــورة لغيرهـــا ، لأن هــــا

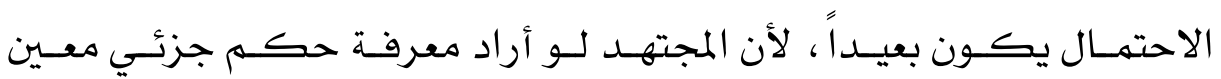
فاسـتقرأ جميـع الجزئيـات المثـابهة لـه فـإن حكــم هـــه الجزئيـات يثبـت

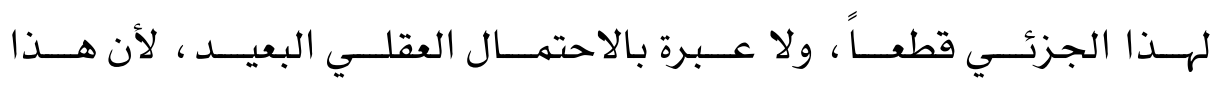

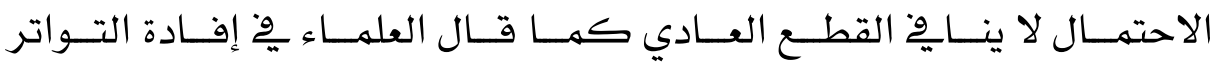

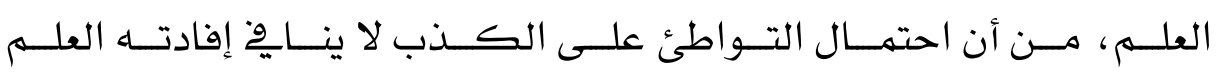

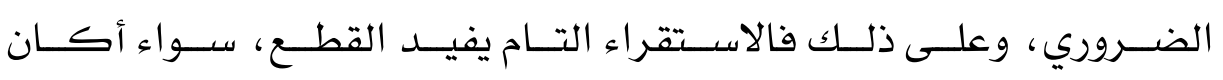
المطلوب باه إثبات حكم مسـألة معينة ، أم قاعدة عامة (؟).

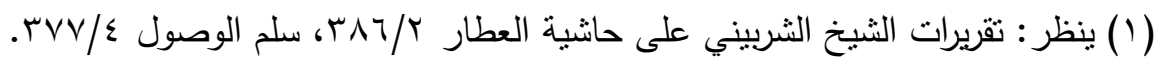

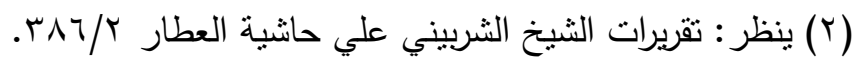




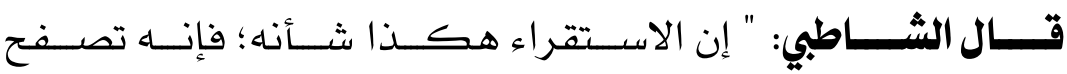

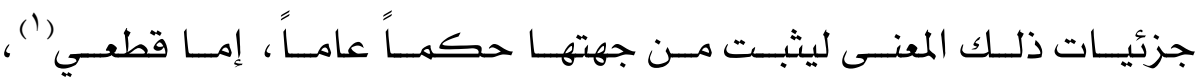

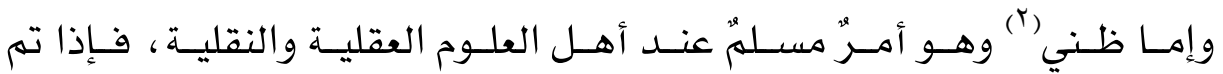

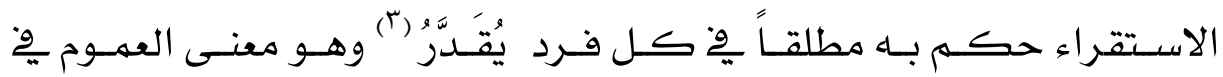
هذا الموضوع أ.هـ"(ع).

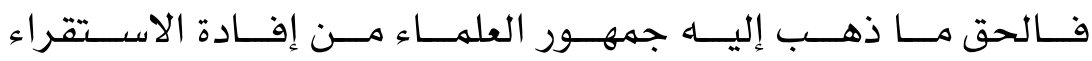

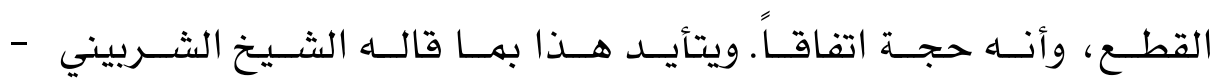

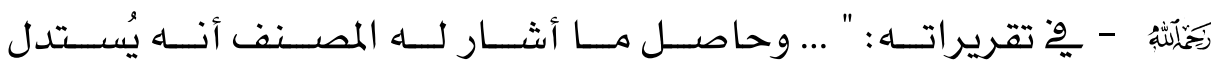
بإثبــات الحكـــم للجزئيــات الحـاصـل بتتيــع حالهـا علـى ثبــوت الحكــم

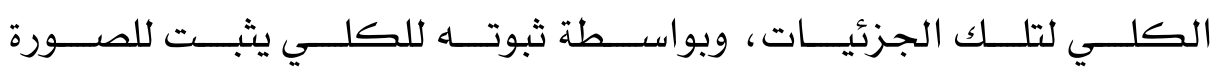

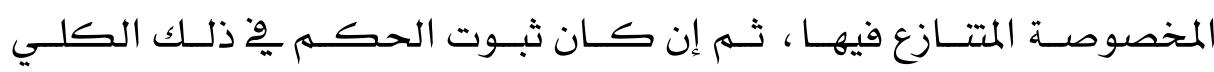
بواســـة إثباتــاه بـالتتبع لجميـع الجزئيـات مـا عـــا صــورة النـزاع كــان

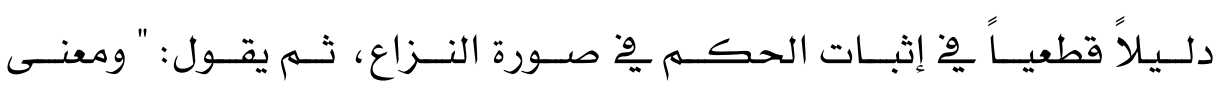

(1) وهو الاستقراء التام، أي القسم الأول من أقسامه. (r) وهو الاستقراء الناقص، أي القسم الثاني من أقسامه، وذلك إذا كان في غالب الجزئيات الأنهاء فقط. (r) أي: يفرض وإن لم يجئ فيه نص. كذا قاله المحقق في الهامش.

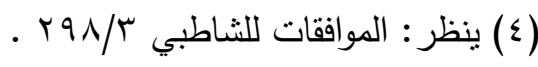




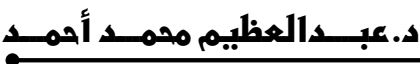

تنقيع الإراء في حجيميت الإستقراء سلان

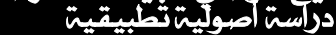

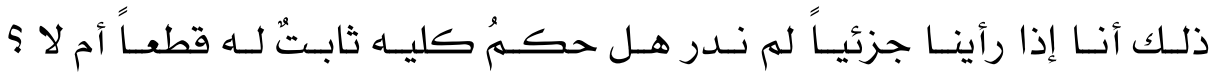

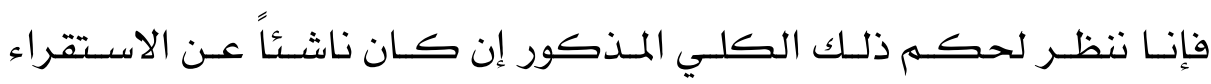

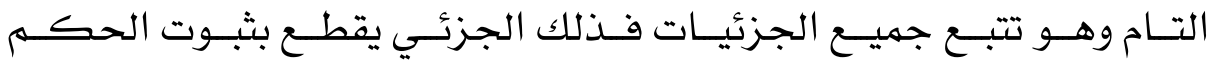

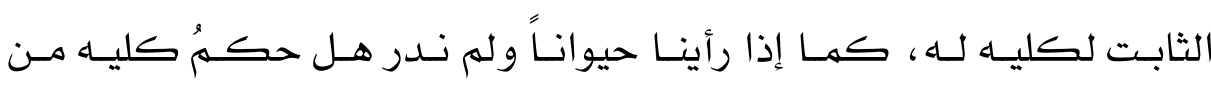

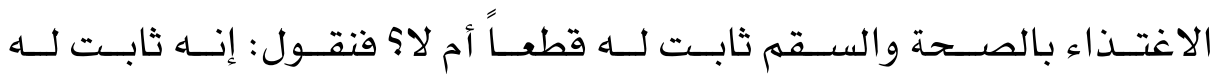

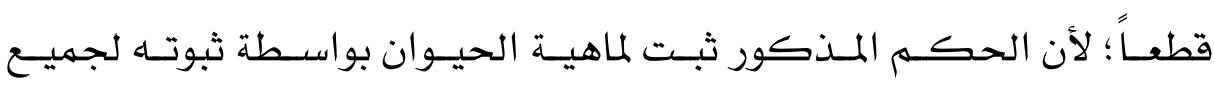
جزئياتها أ.هـ" (').

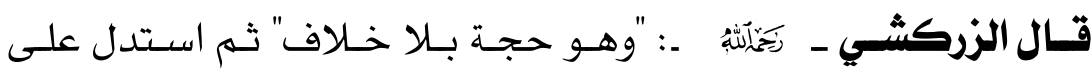

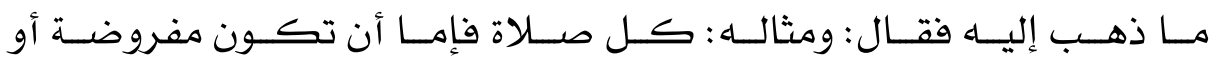

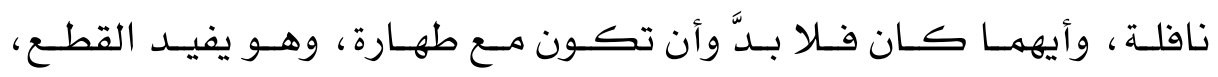

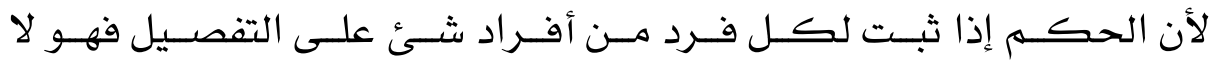
محالة ثابت لكل أفراده على الإجمال أ.هـ"(').

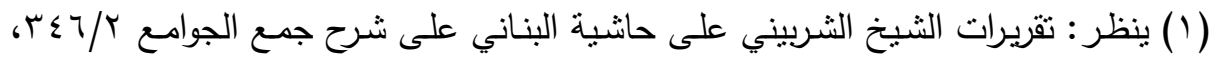

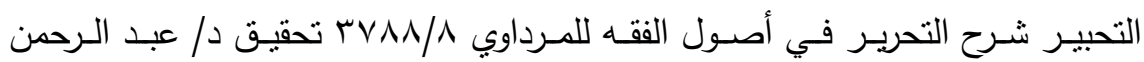
الجبرين، عوض القرني، أحمد السراح

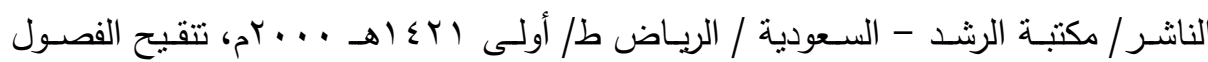

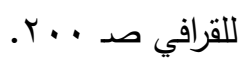

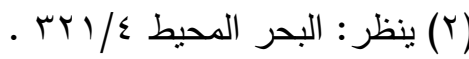




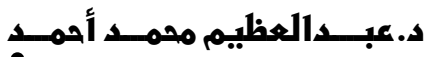

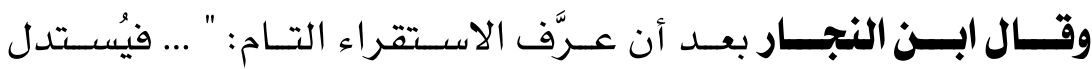

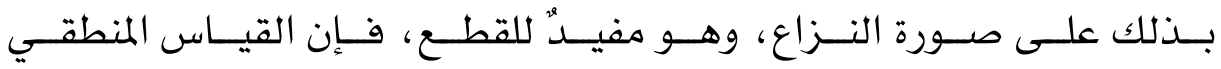
مفيدٌ للقطع عند الأكثر أ.هـ"(')

\section{الإطلب الثاني}

\section{الاستقراي الناقص وحكمه}

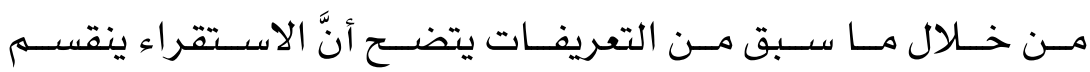

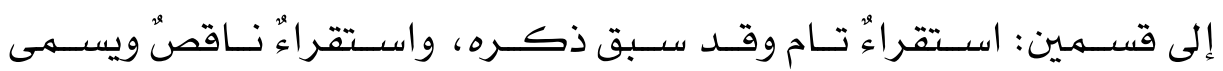

عند الفقهاء بإلحاق الفرد بالأعم الأغلب (r).

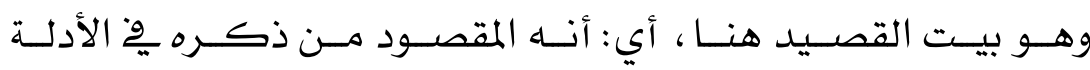

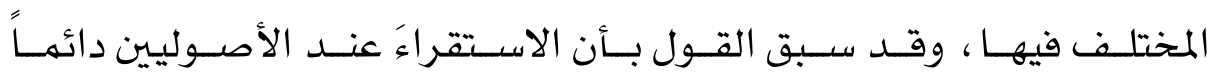

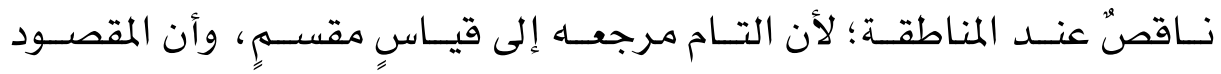

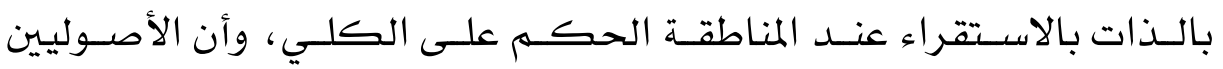

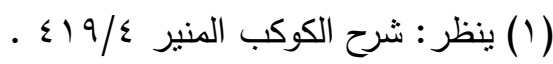

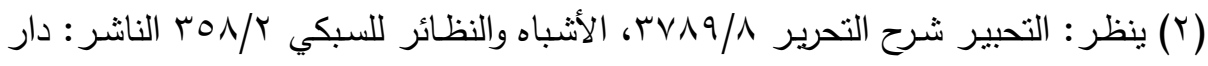

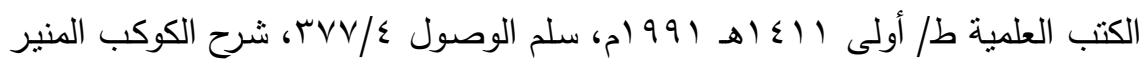

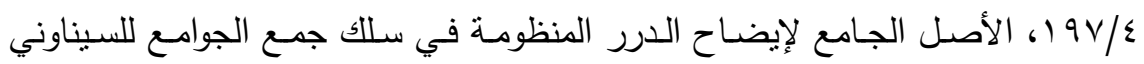

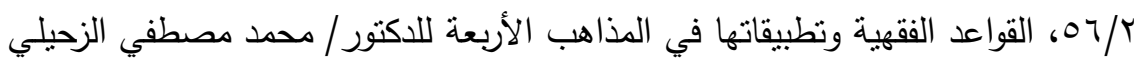

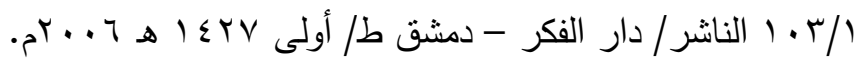




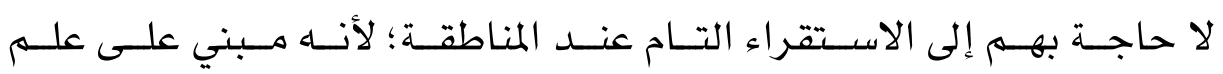

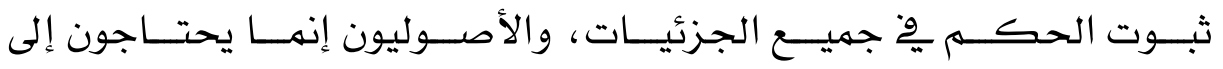

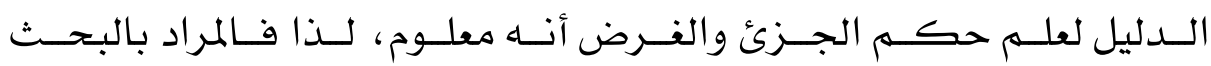

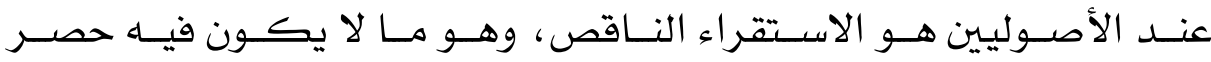

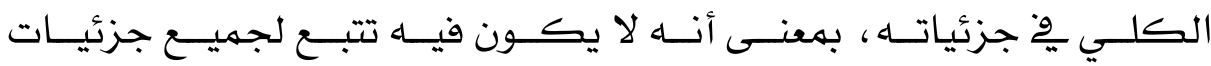

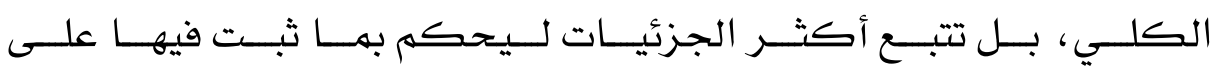

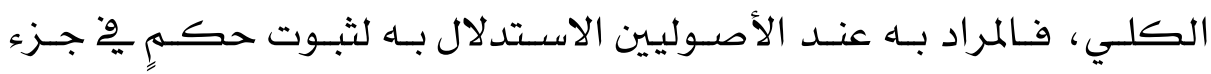
من جزئيات الكلي.

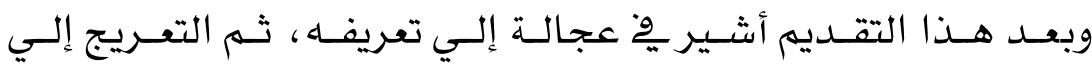

بيان حكمها فأقول مستمداً العون من الله تعالي:

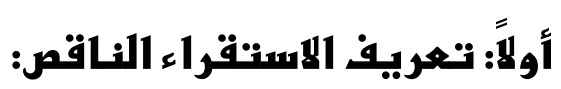

عُرِّف الاستقراءُ الناقصُ اصطلاحهاً بعدة تعريفاتٍ منها :

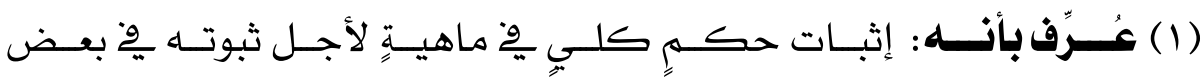

$$
\text { أفرادها'('). (1) }
$$

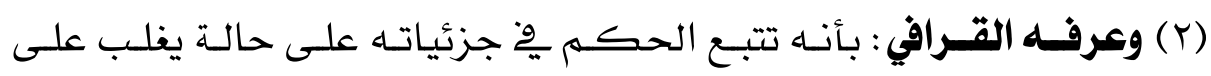

$$
\text { الظن أنه بِّ صورة النزاع على تلك الحالة). }
$$

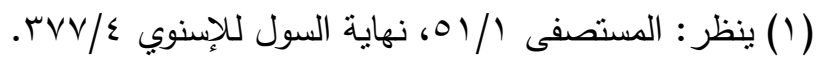

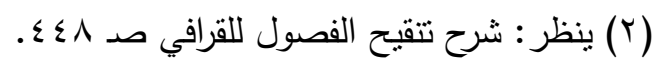




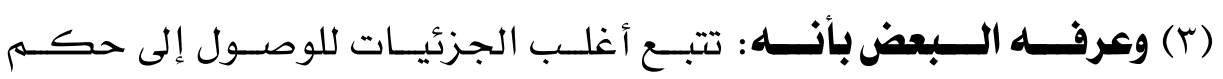

$$
\text { صورة مِّْ محل النزاع ('). }
$$

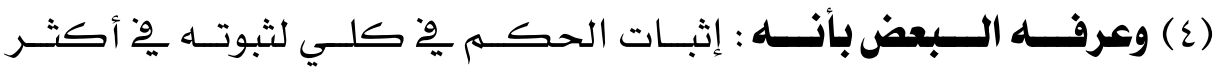

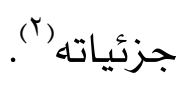

(0) وعرفـه الـبعض بأنهـه: تصـفح أمسور جزئيـة لـيحكم بحكههـا علـي

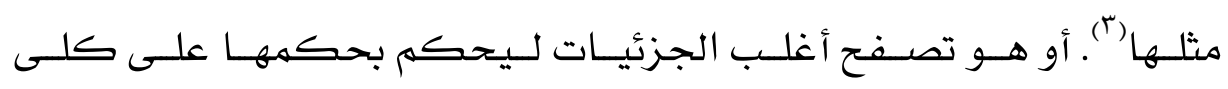
يشهملها (๕) . بعـد عـرض هـذه التعريفـات يتـبـين أنهـا متقاربـة ، إذ كلـها مجتهعـة على

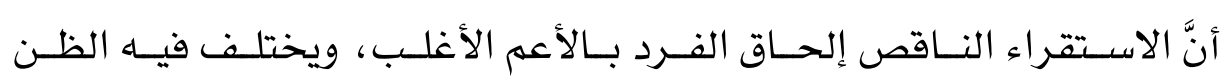

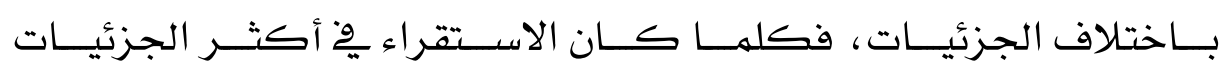
كان أقوى ظناً (0).

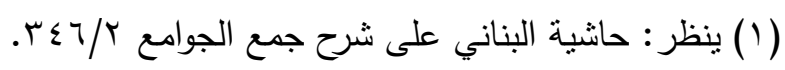

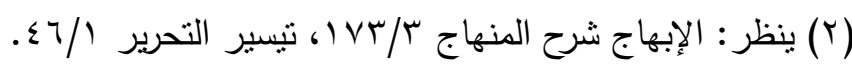

(r) ينظر : روضة الناظر وجنة المناظر في أصول الفقه على مذهب الإمام أحمد بن حنبل لابن قدامة /90/ الناشر/ مؤسسة الريّان للطباعة والنشر والتوزيع الطبعة: الطبعة الثانية

$$
\begin{aligned}
& \text {. } \\
& \text { (هنظر : دراسات أصولية في القرآن الكريم للثيخ/ الحفناوي صد هب ا. }
\end{aligned}
$$

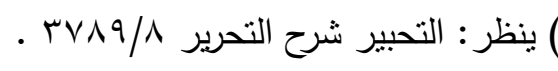




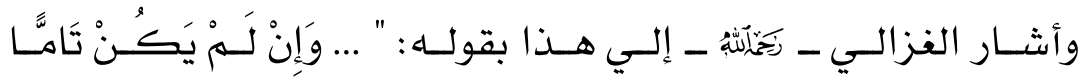

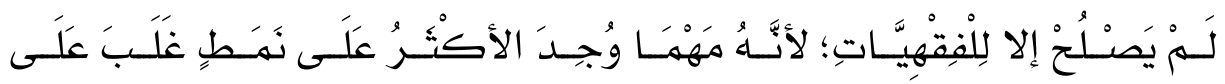

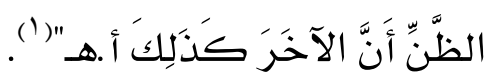

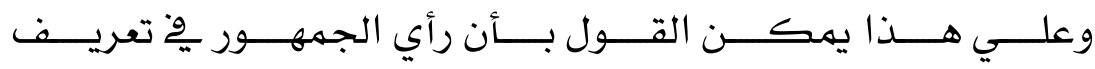

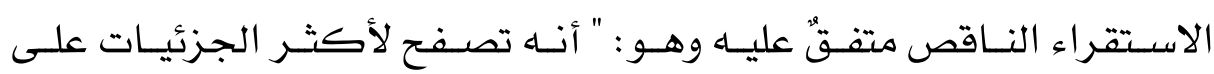
حالـة يغلـب الظـن أنـه وِّ صـورة النـزاع كــلك، ولا يثـترط وجـود جـامع بـين هــذه الجزئيـات " ويتأيسد هـذا بهـا سـبق ذكـره، وبهـا عرَّفَهَه بـه الإمـام

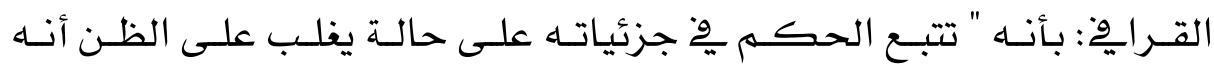

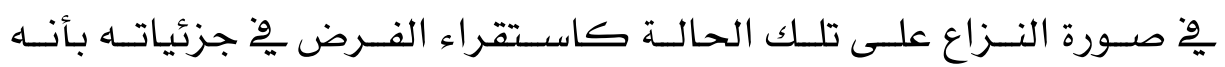

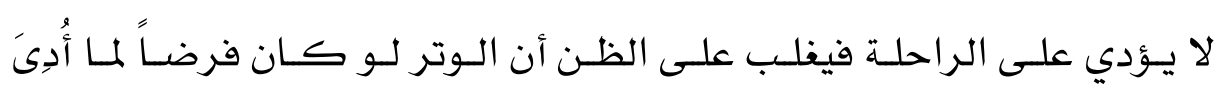

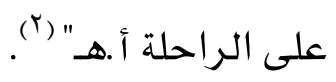

وعلـي ضـوري ذلــك فـإنَّ تلــك التعريفـات تثـير إلى أنـه كلهـا كــان

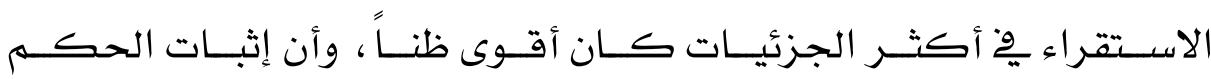
للكـــي المشـترك بــين جميــع الجزئيـات بشـرط أن لا تتـبـين العلـة المـؤثرة

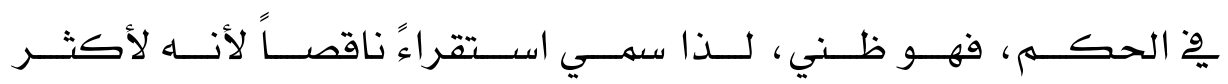
الجزئيـات، فـلا يكــون فيـاه تتبـع لجميـع الجزئيـات، فـإن كــان لجميـع

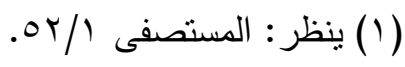

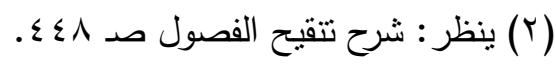


الجزئيــات فهــو المــراد عنــد المنـاطقــة ولـيس هــو المــراد عنــد الأصــوليـين

(1) كما تقدم

\section{نانباً: هكم 1111}

بعـد أن ذكـرت مــا قالــه العلهـاء مِّ الاســتقراء التـام، وأنــه يفيـد

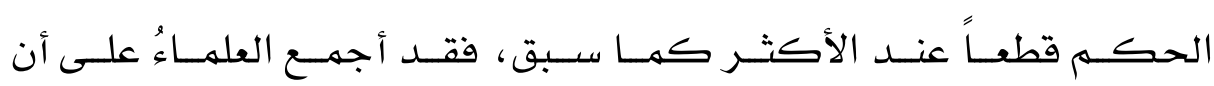

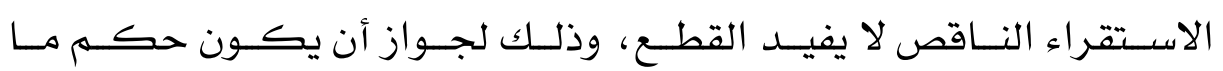

لهم يُستقرأ من جزئياتٍ على خلاف ما استقرىئ منها (؟).

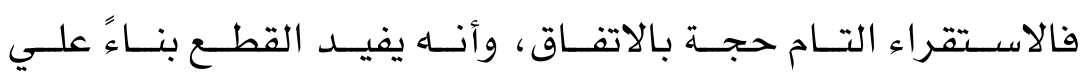

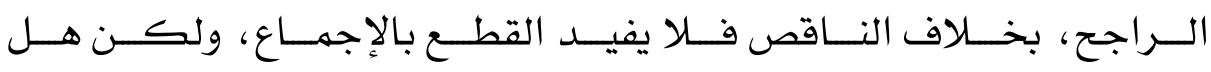

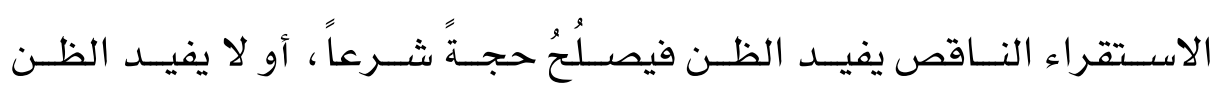
أيضناً فلا يصلُحُ حجةً شرعاًٌ

اختلف العلماء ِِّْ ذلك على قولين:

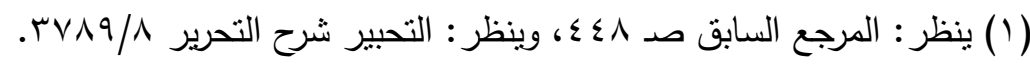

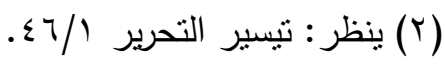


القول الأول: وهو لجههور العلماء من المالكية، والشافعية، والحنابلة، أنـه يفيد الظن وحجة يجب العمل به، وقد رجع إلي هذا القول أكثر الحنفيـة أيضاً (1)

القول الثنانـي: وهو لبعض العلماء وهو المختار للإمـام الـرازي يِّ المحصـول: أنه لا يفيد الظن علي الأظهر (r).

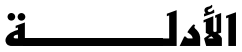

أولاً: استدل الجههور علي أنَّ الاستقراء الناقص يفيد الظن، وأنه حجة يجب

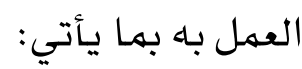

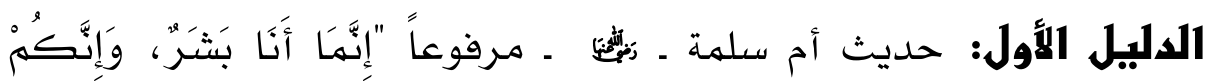

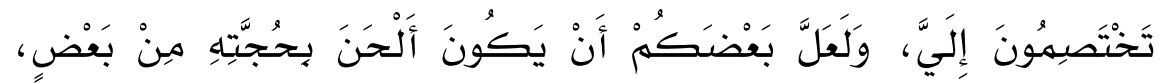

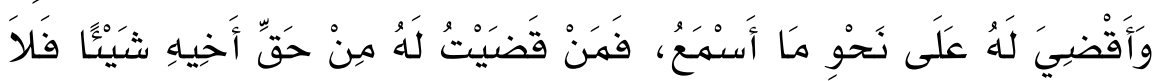

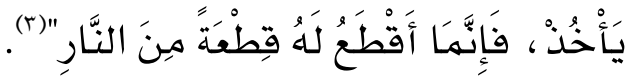

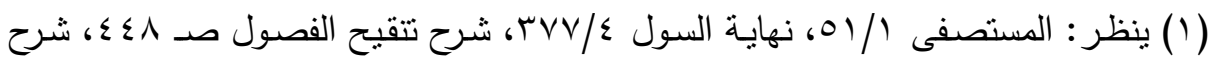

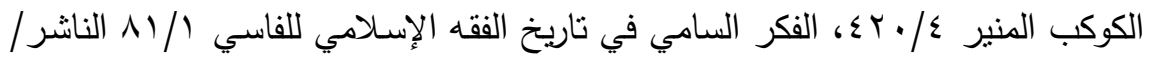

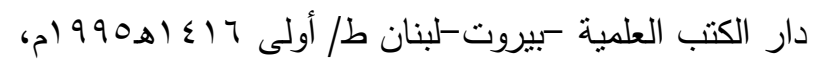

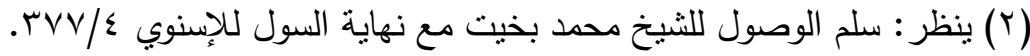

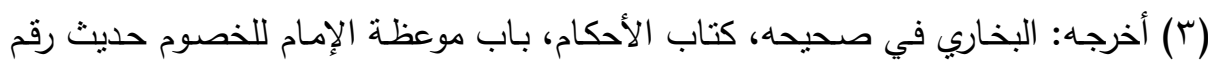

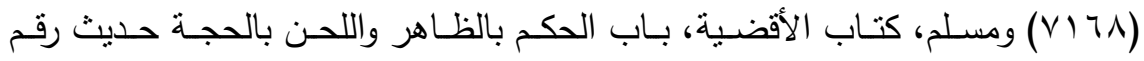




\section{وجه الدلة من الهدبث:}

إن هـذا الحـديث يـدل علـى وجـوب العهـل بـالظن، وحيـث وجـب

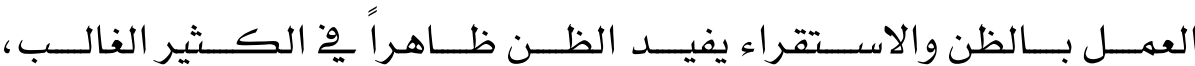

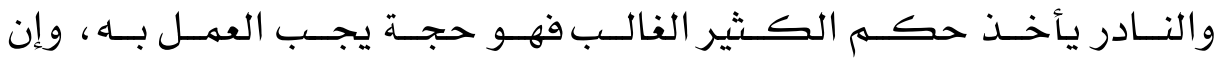

كـان الظـن يختلــف بـاختلاف الجزئيــات المســتقرأة إلا أنــه يجــب العهـل

تبعاً لذلك (')

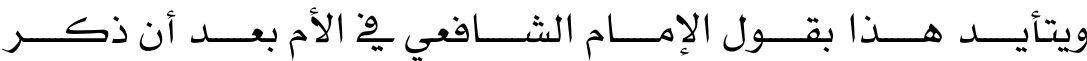

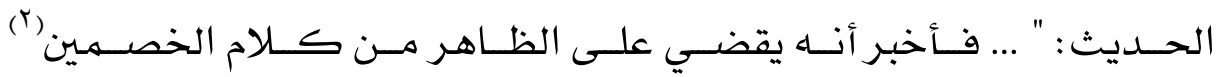

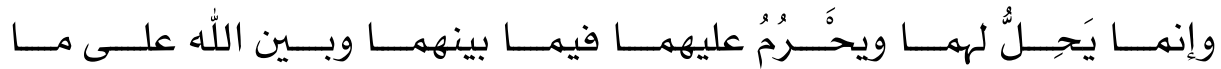

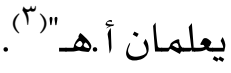

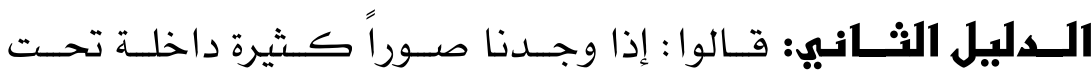

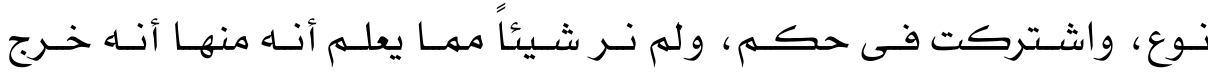

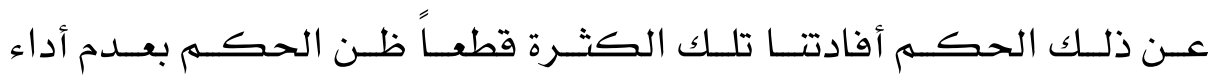

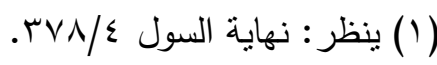

(Y) وهذا القضـاء لا يغير من حلِّ أو حرمـة الثـيء المقضـي بـه ديانـة، فقد يحكم القاضـي

بشهادة الشهود ظاهراً ولكن قد يكون ذلك باطلاً ديانة بين العبد المحكوم له وربه.

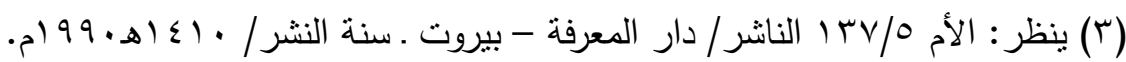


الفــرض راكبــاً، والــوتر يُفعـل راكبــاً، فلــيس واجبــاً () لاســتقراء

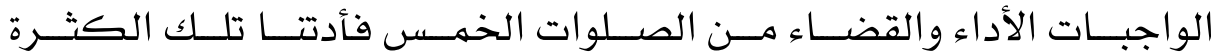
الحكــم بعــدم أداء الفـرض راكبــاً، وهـــو الصــلاة الواجبـة، و وإذا كــان ذلك مفيداً للظن كان العمل به واجباً (r).

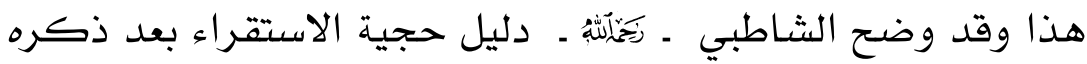
معنى الاستقراء من أن له حكم الصيفة ِِّ إثبات العموم فيقول: العموم إذا ثبت فلا يلزم من جهة صيغ العهوم فقط، بل له طريقان:

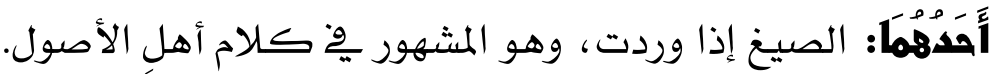

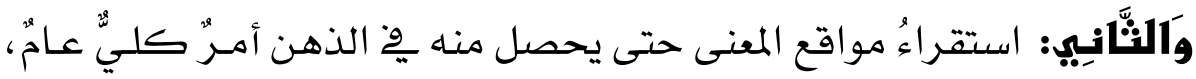
فيجري مجرى العموم المستقاد من الصيغ، والدليل على صحة هذا الثاني

وجوه.

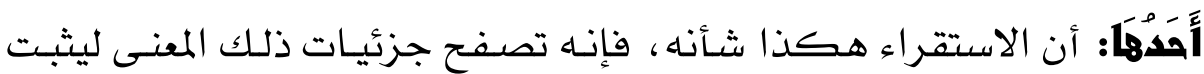

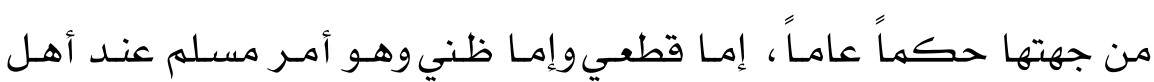

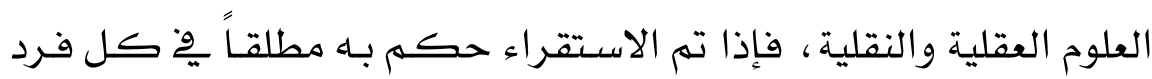
يقدر وهو معنى العموم المراد ِِّ هذا الموضع.

(1) سيأتي الحديث عن حكم صلاة الوتر في الأثر الفقهي بإذن اله تعالي.

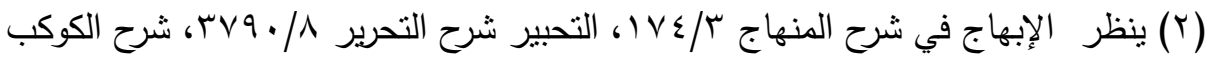

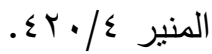


وَالفَّانِيه: أن التواتر المعنوي هذا معناه، فإن جـود حـاتم مثلاً إنما ثبـت على الإطـلاق مـن غير تقييـد ، وعلى العهـوم مـن غـير تخصـيص، بنقـل وقائع

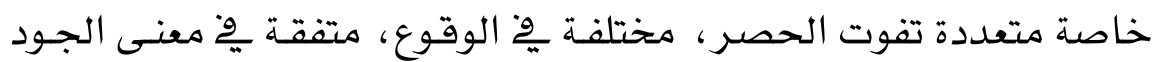

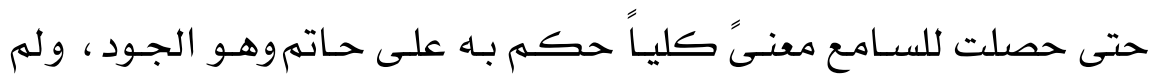

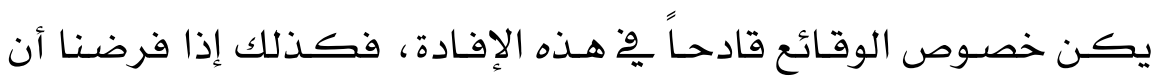

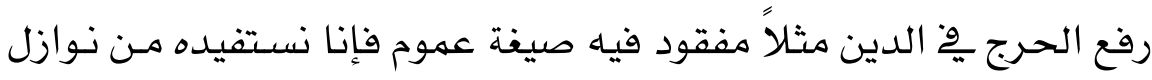

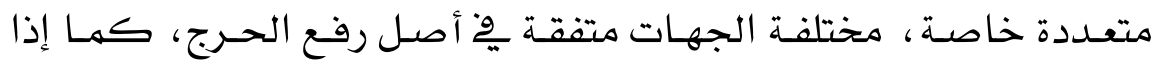

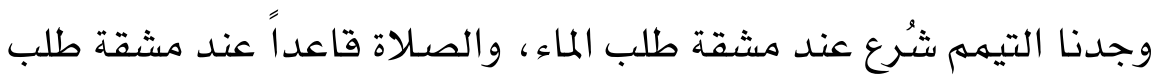

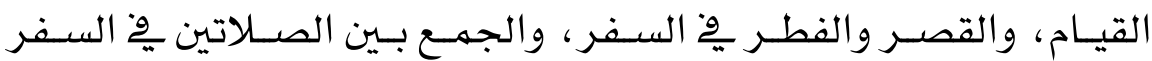

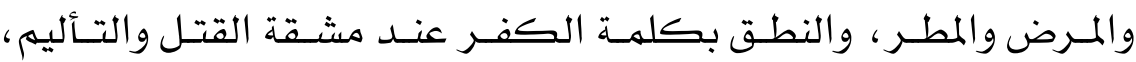

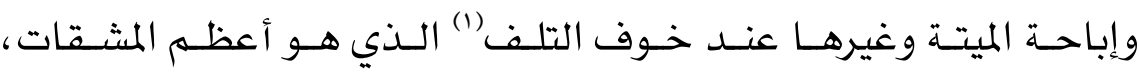
والصلاة إلى أي جهة كـان لعسـر استخراج القبلة، والمسـح على الجـبيرة والخفين لمشقة النزع ولرفع الضرر، والعفو وِّ الصيام عما يعسر الاحتراز

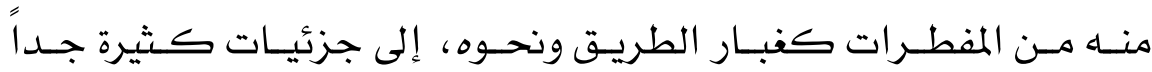
يحصل من مجموعها قصد الثارع لرفع الحرج، فإنا نحكم بهطلق رفع

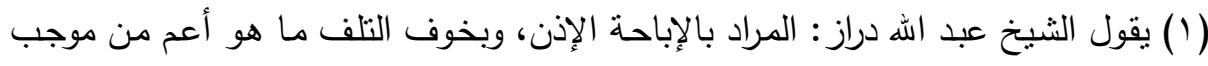

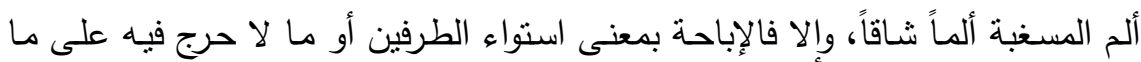

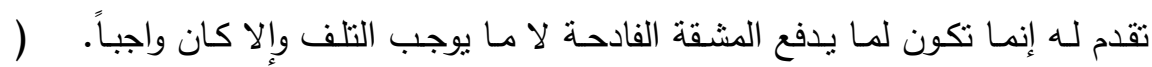

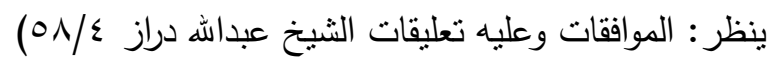




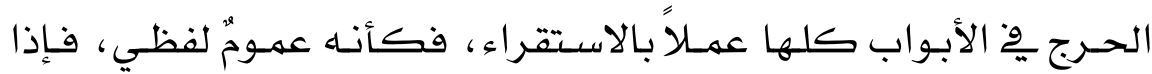
ثبت اعتبار التواتر المعنوي ثبت فِّ ضهنها ما نحن فيه (1).

والفنالْْ: إن قاعدة سـد الذرائع إنها عمل السلف الصـالح بها بنـاء على هـذا

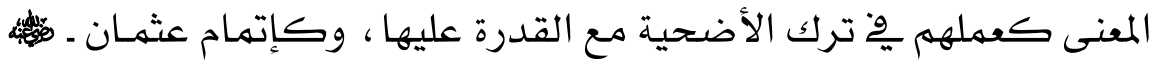

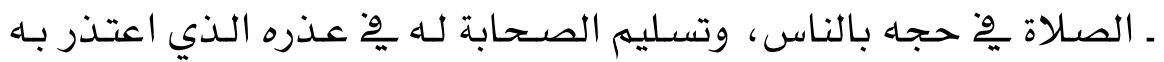
مـن ســدِّ الذَّريعـة إلى غـير ذلـك مـن أفرادهــا الـتي عملــوا بهـا ، مـع أن المنصوص فيها إنها هـي أهـور خاصـة لا تتلاقى مـع مـا حكهـوا بـه إلا حِ معنى سـد الذريعة وهو دليل على ما ذكر من غير إشكال(r).

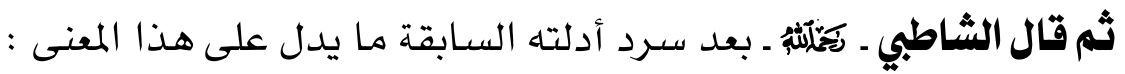
ولهذه المسـألة فوائد تتبنى عليها ، أصلية وفرعية، وذلك أنها إذا تقـررت عندـ

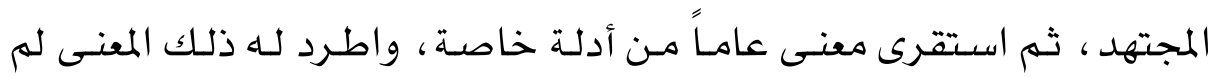
يفتقر بعد ذلك إلى دليل خاص على خصوص نازلة تَعِنه، بل يحكىم عليها وإن

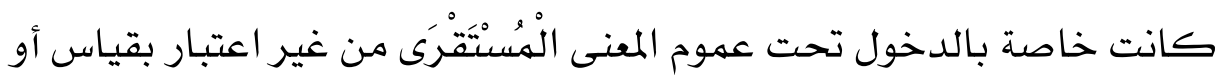

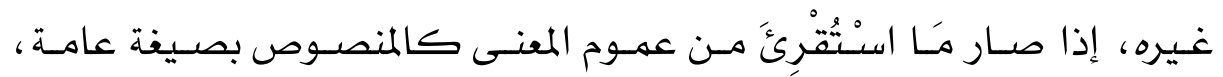
فكيف يحتاج مع ذلك إلى صيفة خاصة بمطلوبه (r).

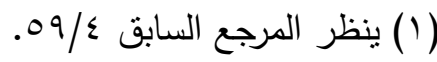

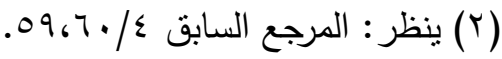

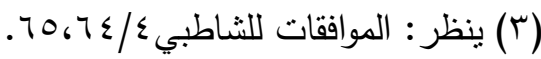


الـدليل الثنالـث: واسـتدلوا بالإجهـاع فقـالوا : إن الإجهـاع واقع على العهـل بالاستقراء الناقص على الجملة، فإنتا لما علمنـا اتصـاف أغلب مـن ِِّْ دار الحرب، أو وصفهم بالكفر غلب على ظنتـا أن جميع مـن نشـاهده منهم كذلك، حتى جـاز لنـا اسـترقاق الكل، ورهـي السهام إلى جميـع مـن ِِّ

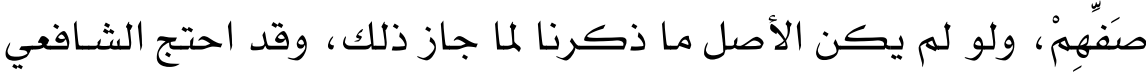

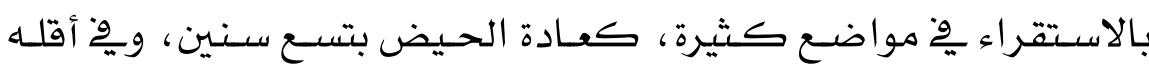

$$
\text { وأكثره، وجرى عليه الأصحاب (1). }
$$

الهليل الرابـر: اسـتدل القـائلون بحجيـة الاسـتقراء النـاقص أيضـاً بالقيـاس فقالوا : إن القياس التمثيلي مفيدٌ للظن باتفـاق القـائلين بالقياسووهـو أقل رتبة من هذا الاستقراء، فإفادة الاستقراء للظن من باب أولى؛ لأن القياس

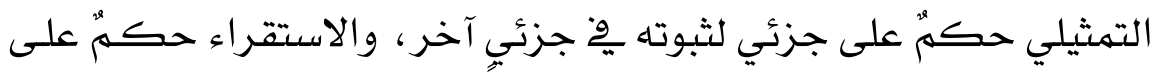

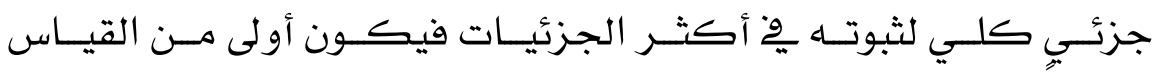
التمثيلي (r)

\section{ثانبياً: أدلة القائلين بـهدم حجية الاستنقراء الناقص:}

استدل القائلون بعدم حجيته بأدلة منها :

الدليل الأول: قـالوا بـأن الشـرع لم يـرد بكل حكـم جزئي تقصيلاً حتى يستدل بالجزئيات على الحكم الكلي، وإن قيل بوروده بالعموم فلم يبق بـ بـ

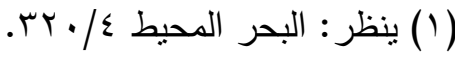

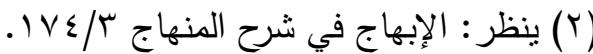


اسـتقراء بـل العهـوم هـو الـدليل، إلا إذا دل على وصـف جـامع للجزئيـات فحينئذ الحكم بهذا الوصف والاستقراء إنهـا هـو لتحققهـ هِّ الجزئيـات فآل إلى القياس (1).

الدليل الثنانبي: وهو ما استدل به الإمام الرازي ومن تبعـه على عـدم حجيـة

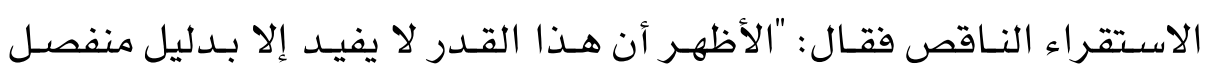
أ هــ" (r) أي: أنَّ الاستقراء الناقص لا يفيد الظن إلا بدليل منفصل.

\section{والنـاظر فى أدلة المانـهبن بـر الآتى:}

أولاً: أن الدليل الأول مبنى على أن الشرع له يرد بكل حكم جزئى تفصيلاً حتى يُستدل بالجزئيات على الحكم الكلى، وقالوا بعد أن اعترفوا بالعموم المعنوى الوارد من هذه الجزئيات واستتدوا إلى العموم فى الاستدلال،

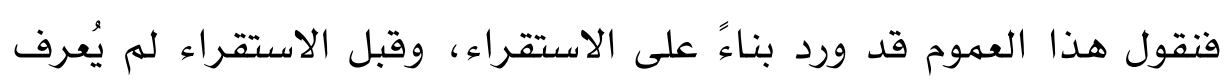
العموم؛ فإذا تم العموم بالاستقراء فلا طلب لدليل التخصيص، وهذا مقصود

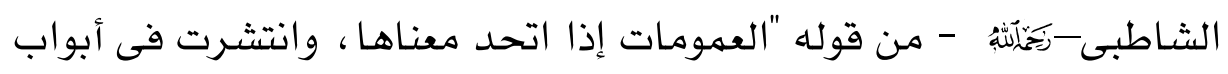
الشريعة، أو تكررت فى مواطن بحسب الحاجة من غير تخصيص فهى

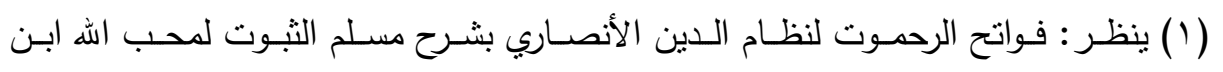

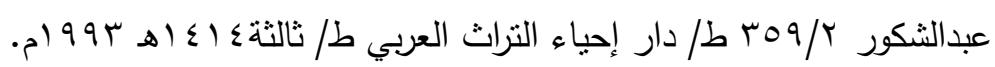

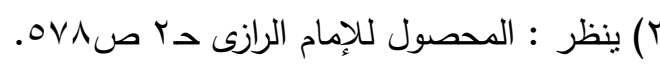


مُجْرَاةُ"(1) على عمومها على كل حال، وإن قلنا بجواز التخصيص بالمنفصل. والدليل على ذلك الاستقراء: فإن الشريعة قررت أن لا حرج علينا فى الدين فى مواضعَ كثيرة، وله تستثن منه موضعاً ولا حالاً، فعده علماء الملة أصلاً مطرداً وعموماً مرجوعاً إليه من غير استثناء ولا طلب مخصص، ولا احتشام من إلزام الحكم به، ولا توقف فى مقتضاه، وليس ذلك إلا لما فهموا بالتكرار والتأكيد من القصد إلى التعميم التام؛ ولأن ما حصل فيه التكرار والتأكيد والانتشار صار ظاهره باحتقاف القرائن به إلى منزلة النص القاطع الذى لا احتمال فيه، بخلاف ما له يكن كذلك فإنه معرضٍ لاحتمالاتٍ، فيجب التوقف بِّ القطع بهقتضاه(؟).

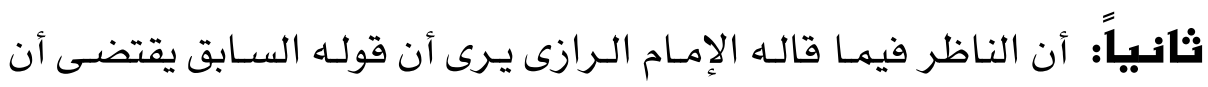

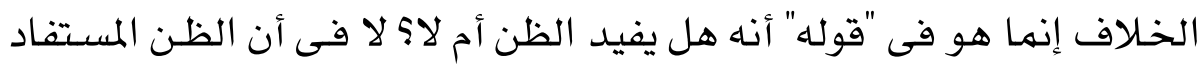

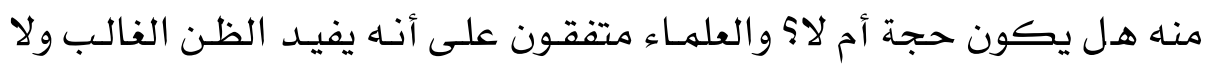

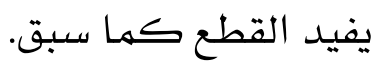
قال صاحب 1لإبـهام: " ... وهذا يُعرفك أن الخلاف الواقع يِّ أنه هل يفيـ

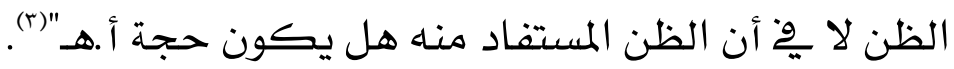
(1) يقول الثيخ عبداله دراز : أي: بدون نوقف ولا بحث عن وجود معارض.

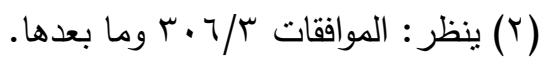

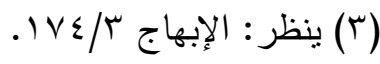


وقال صاهب البهر المهيط: "... واقتضى كـلامـه أن الخـلاف إنهـا هـو يو

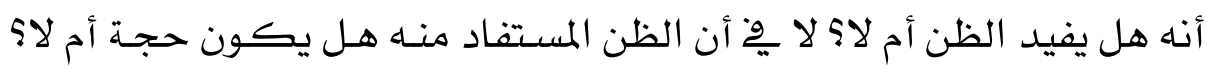
أ (1)" (1) (1)

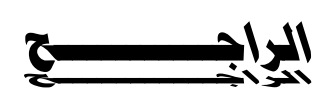

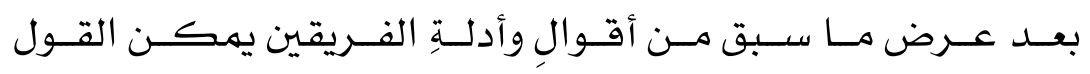

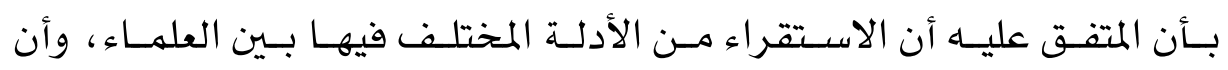

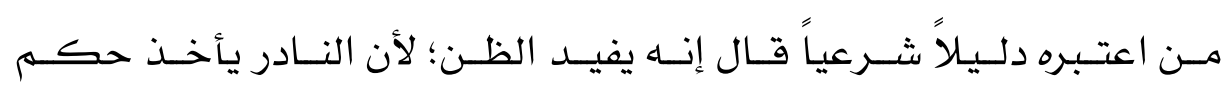
الكثير الغالب فهو حجة يجب العمل به.

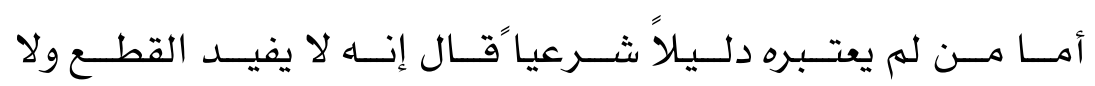

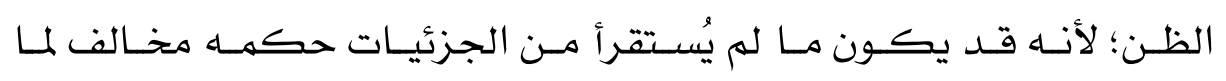

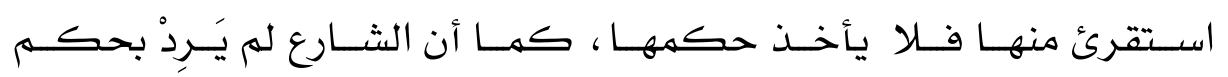
جميـع الجزئيـات حتـى يسـتدل بهـا علـى حكــم الكلـي، أو على جزئيــة أخرى إلا بطريق القياس.

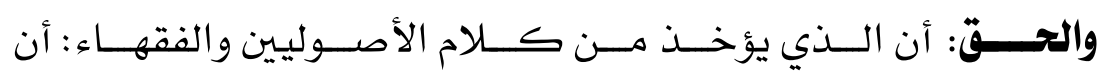

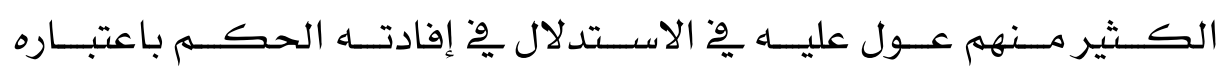
حجــة ، وهــو مـا سيتضــح مـن خــلال المبحــث الخـاص بـالأثر الفقهـي، وهـو (1) ينظر : البحر المحيط \&/YY. 


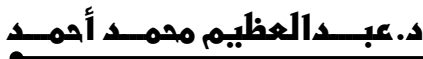

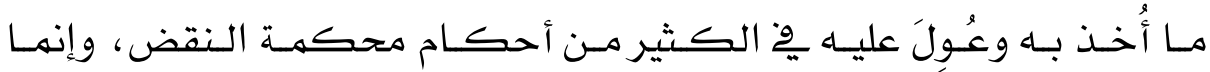
كمن الاختحلاف بينهم مِّم مدى الاعتماد عليه. فالحنفية يذكرون الاستقراء ِِّ معرض الاستدلال للأحكام الشرعية ، وهن ذلك ما ذكروه مِّ سجدات التلاوة، نافين وجود سجدة ثانية

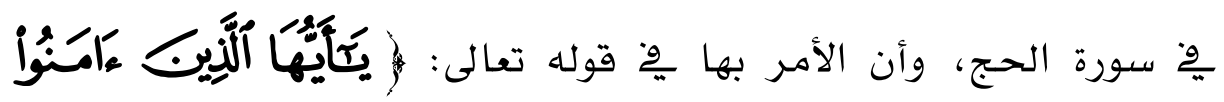

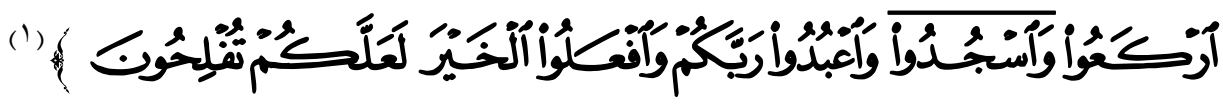
بأن المراد بها بالسـجود إنها هو للصسلاة(r).

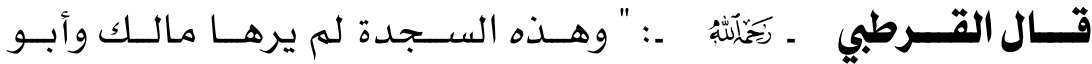

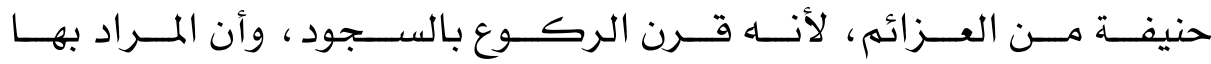
الصـلاة المفروضة ، وخص الركوع والسجود تشريفاً للصسلاة "("). وقة ال الشـوكاذي بعـد ذكــره لهـذه الآيـة أيضــاً: أي صـلوا الصـلاة الـتي شـرعها الله لكـهم، وخـص الصــلاة لكونهـا أشـرف العبـادات، ثـم

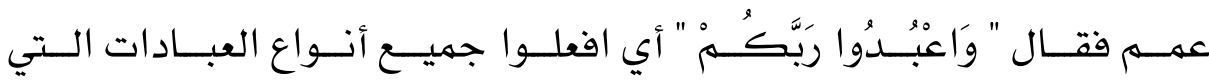

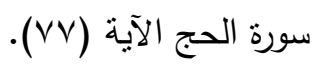

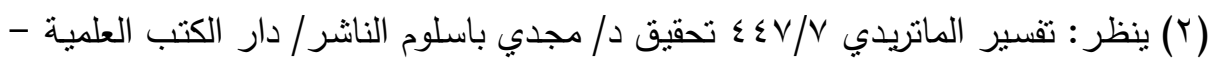

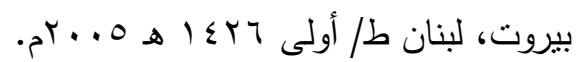

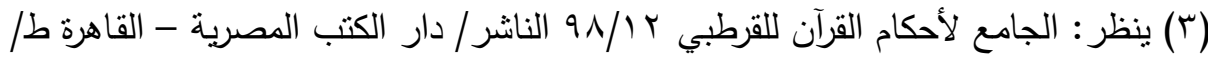

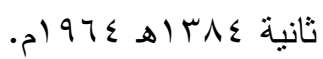




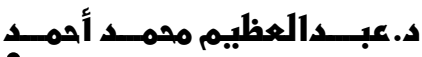

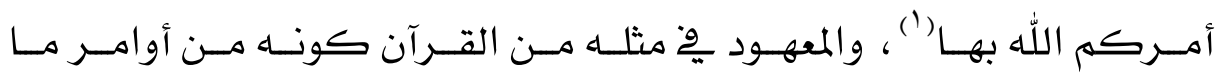

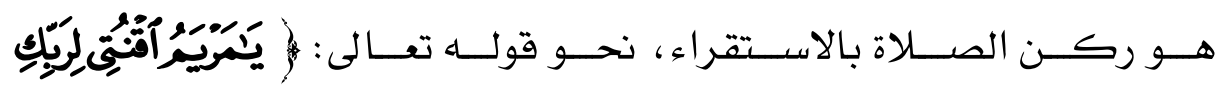

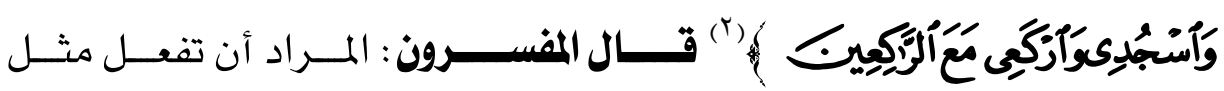
فعلهم وإن له تصل معهم، وقيل: المراد بها صلاة الجماعة"). والحنـابلـة أيضـاً يسـتدلون لأقةل الحـيض وأكثــره بســرد حــوادث عـن نسـاء هـكـذا كــان حيضـهن، وكـذلك وِّأكثـر الحهـل ويقولـون:

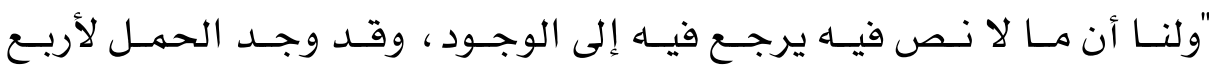

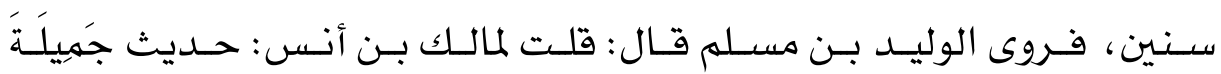
بنْتِ سَعْدِ ، عن عائشة : لا تزيد المرأة على السنتين ِِحْ الحمل.

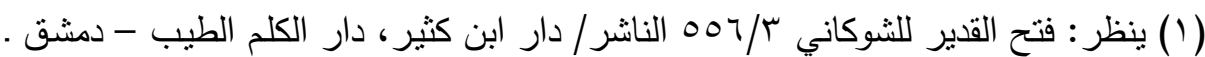

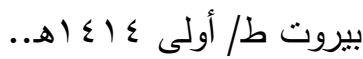

$$
\begin{aligned}
& \text { الآية (س؟) من سورة آل عمران . }
\end{aligned}
$$

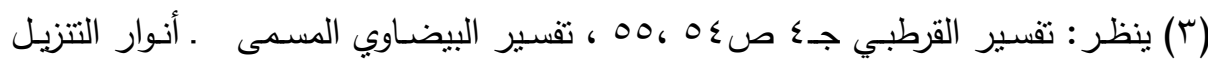

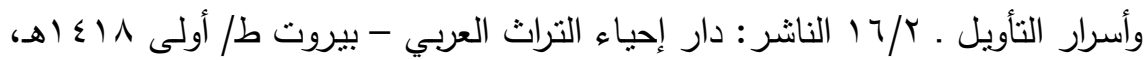

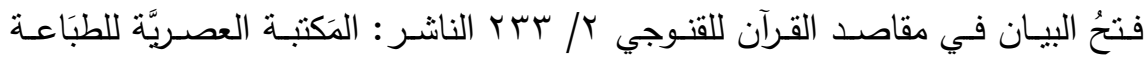

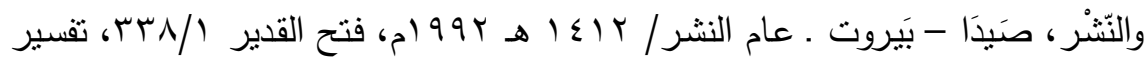

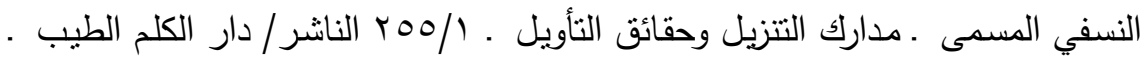

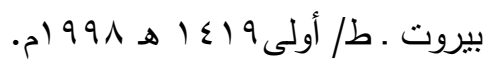




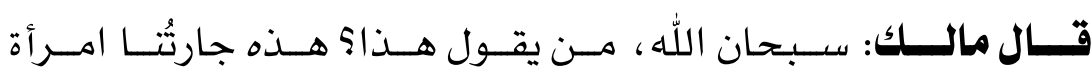
محمد بن عجلان تحمل أربع سنين قبل أن تلد أ.هـ" (')

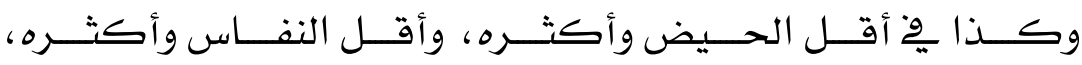

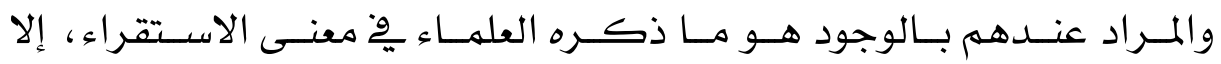

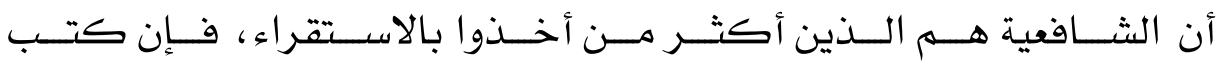
أصــولهم علـى الغالـب هـي الستي تكلهـت عـن هــذا الأصـل ومثلـت لـه، وبينت ما يفيده من حكم وفرعت عليه(؟).

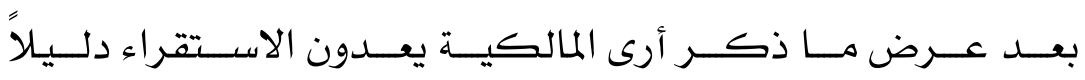

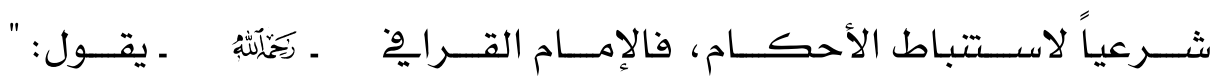

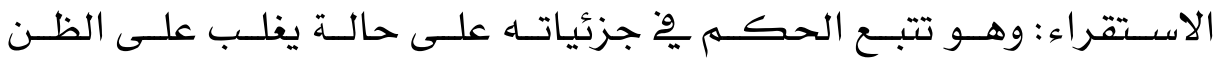

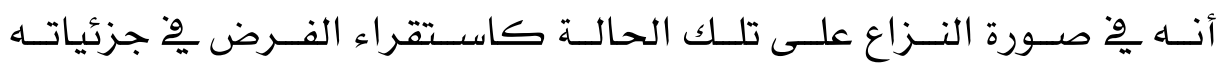

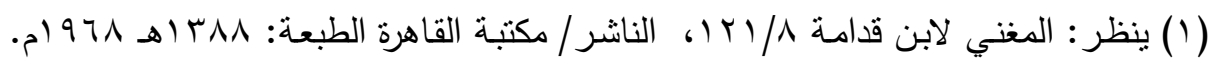

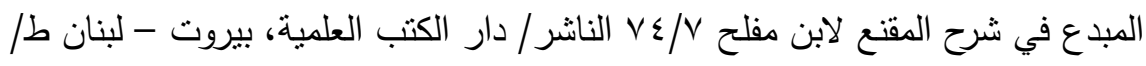

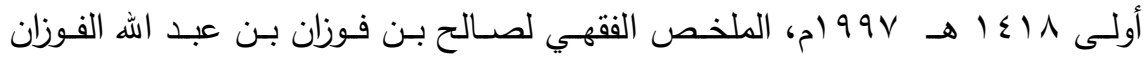

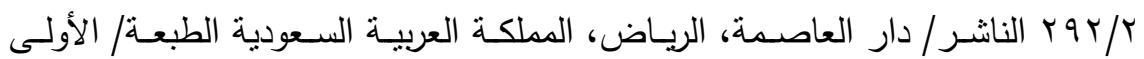
(ه) I $\leqslant$ Tr

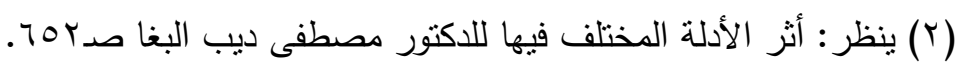




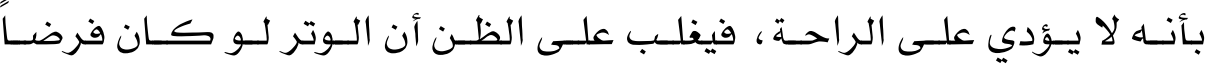
لما أدى على الراحلة ، وهذا الظن حجة عندنا وعند الفقهاء أ.هـ"('). ويقـول الشــاطبي بعــد ذكــره لإثبـات العهــوم وأنــهـ لا يثبــت مــن

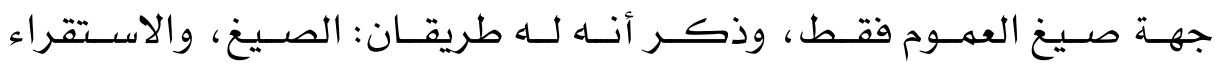
لمواقـع المعنــى، وأن مهـا اسـتقـرى مــن عمــوم المعنـى كالمنصــوص بصــيفة عامـة ، وأنـه لا يحتـاج إلى صـيغة خاصـة بهطلوبـه، ثـم يقـرر بعـد ذلـك أن

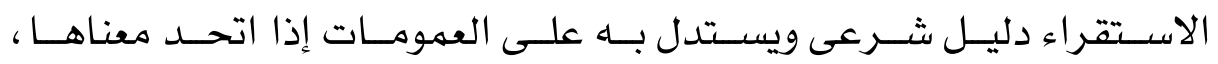

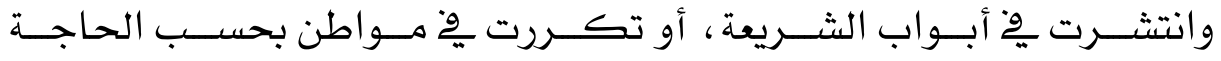
مـن غـير تخصـيص، فهـي مجــراة على عمومهها على كـل حــال، فيقــول: "والــدليل علـى ذلـك الاســقراء؛ فـإن الثــريعة قـررت أن لا حـرج علينـا مِ

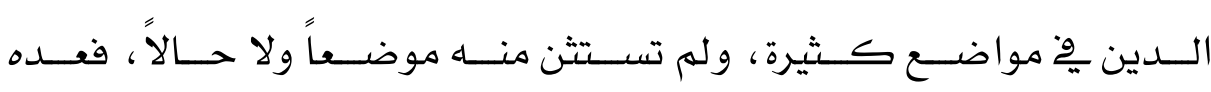

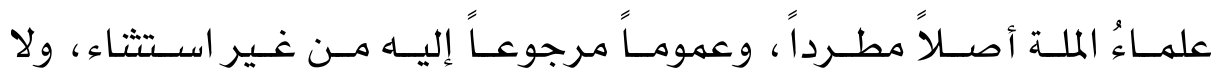

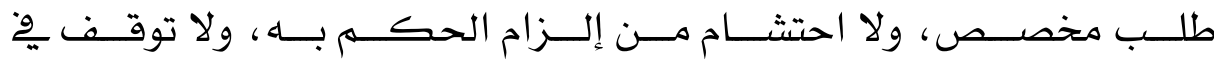
مقتضــاه، ولـيس ذلــك إلا لمـا فهمــوا بـالتكرار والتأكيـد مـن القصــد إلى

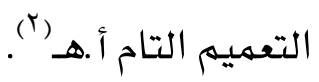

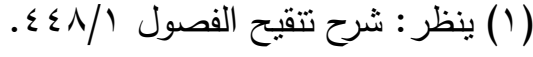

$$
\begin{aligned}
& \text { (ץ) ينظر : الموافقات س/ ؟ • r. }
\end{aligned}
$$




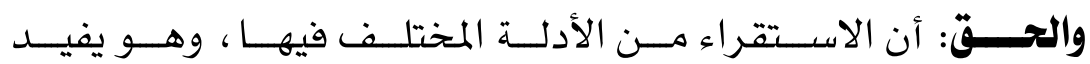

الظـن، والعهـل بـالظن لكثـرة وجـود الاشـتراك يخّ الحكــم يوجـب العهـل

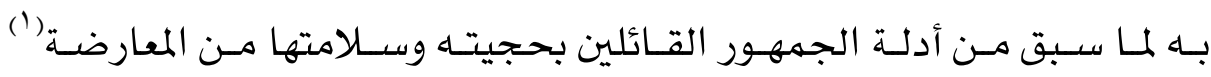
والله أعلم بالصواب.

(1) ينظر : ما سبق في المستصفى للإمام الغزالي //01، البحر المحيط ع// اسب وما بعدها،

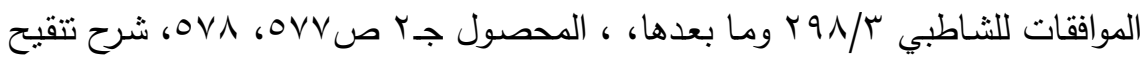

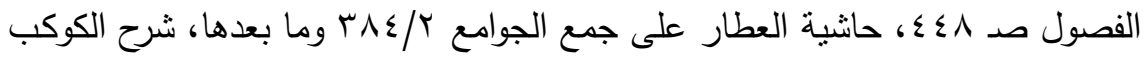

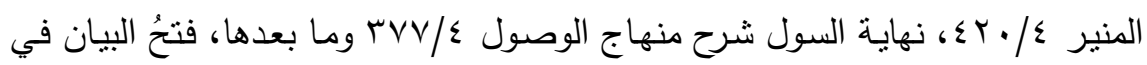

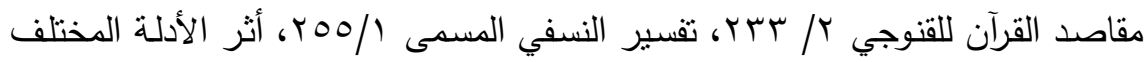

$$
\text { فيها صدم } 7 \text { وما بعدها. }
$$




\section{المبـثخ النالث}

\section{أثر الاستنقراء فيى الهقه الإسلامي وأحكام القضاء}

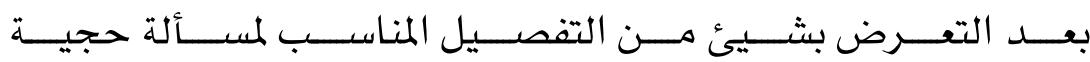

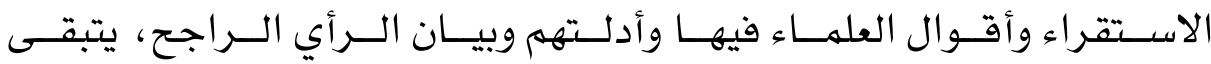

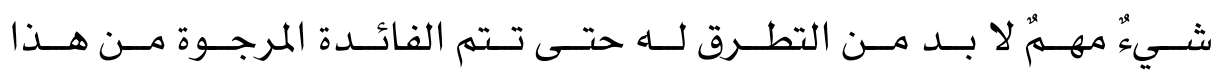

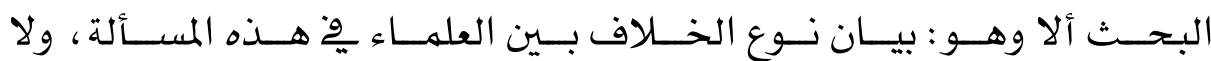

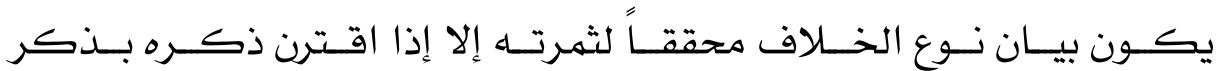
الفروع التطبيقية المخرجة عليه.

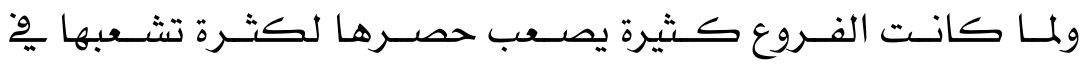

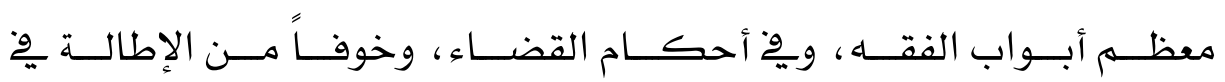

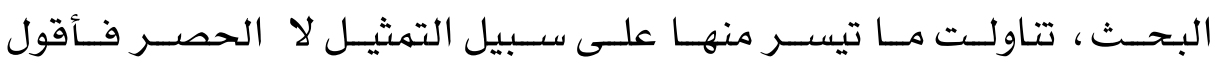

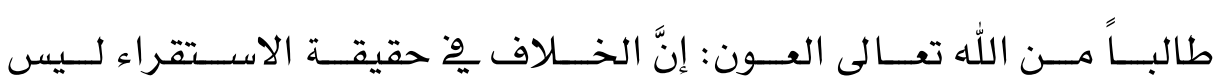

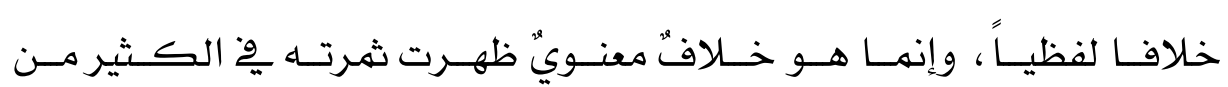

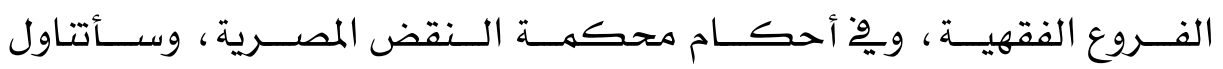
ذلك من خلال المطلبين الآتيين: الاطلب الأول: أثر الاستقراء في الفقه الإسلامي. الاطلب الثاني: أثز الاستقراء في أحكام القضاء. 


\title{
المطلب الأول
}

أنثر لاسبنققراء في الفقه 1الإسلاهي

\author{
الفر ع الأول
}

أقل الهيض وأكثره

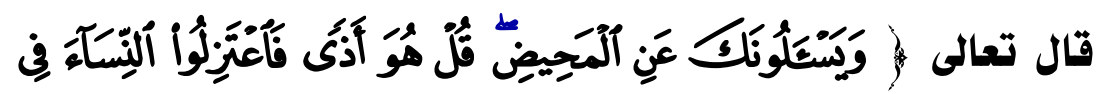

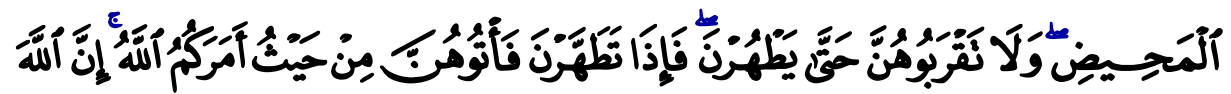

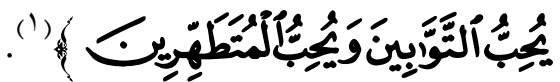

الهيض فيى اللغةة: الحيضُ والحيضاتُ جمع، واحده حيضة ، يقـال: حاضَتِ

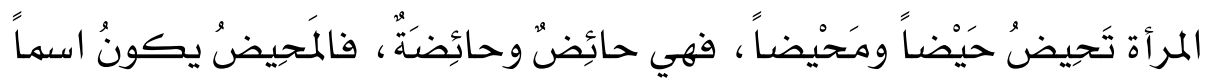

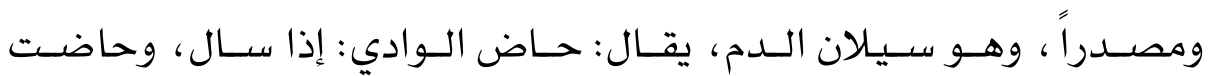

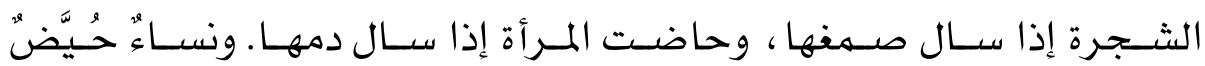

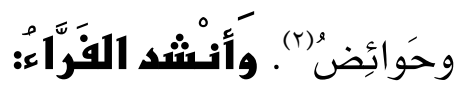

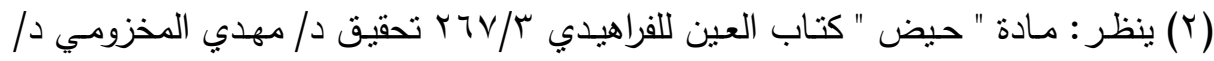

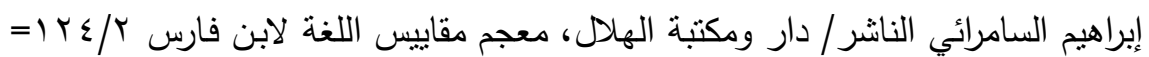




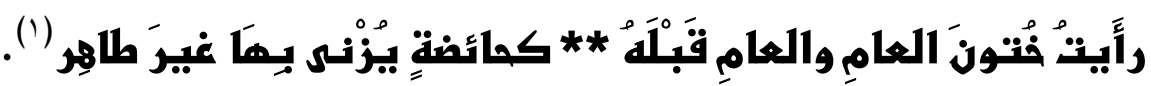
وفــي الاصــطلام: هـــو اســم لــدم يخــرج مــن الــرحم لا بعقــب

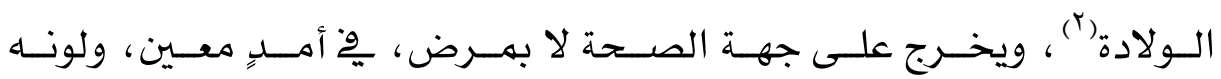

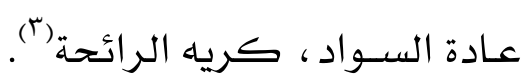

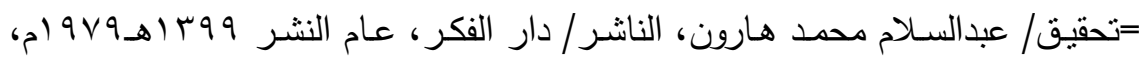

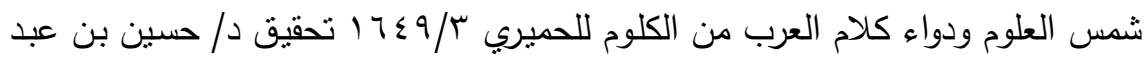

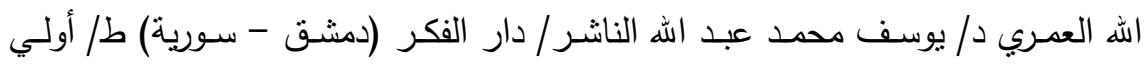

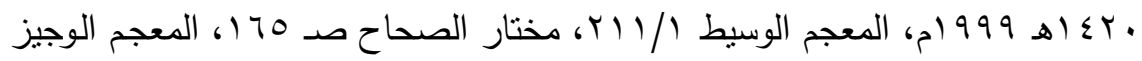

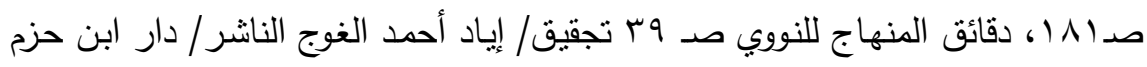

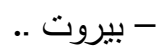

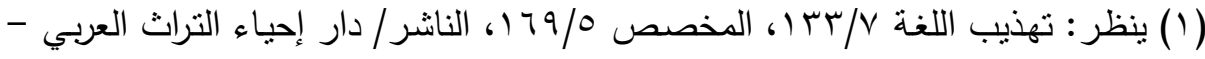

$$
\text { بيروت }
$$

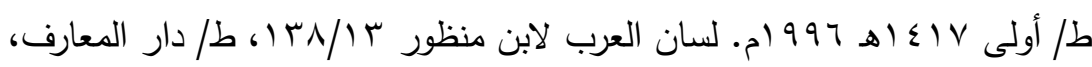

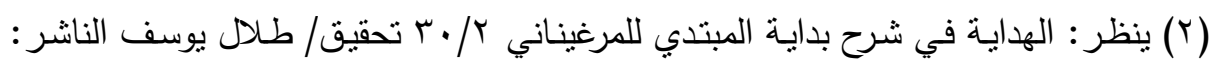

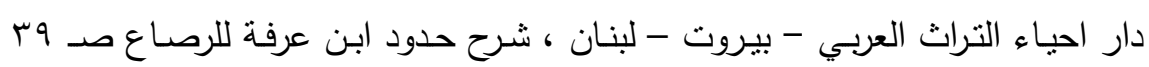

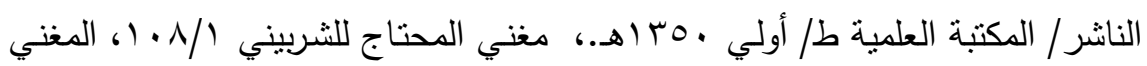

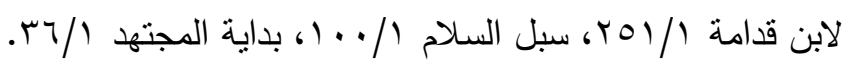

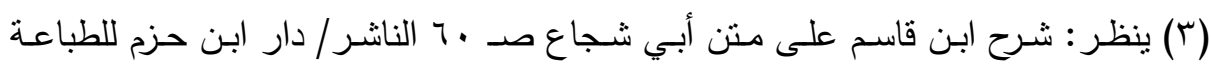

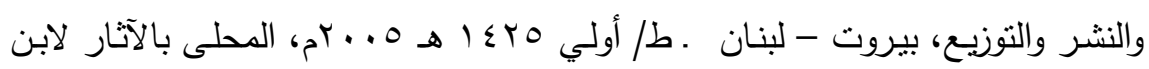

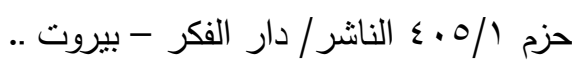




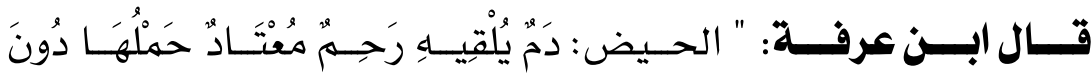

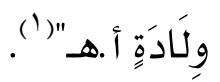

وقتـال الإمسام النـووي: " الحسيض جريـان دم المـرأة ِِّْ أوقـات معلومــة

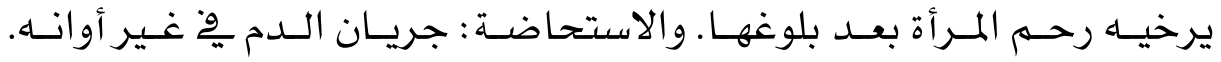
قـالوا :ودم الحسيض يخــرج مـن قعـر الـرحم، ودم الاستحاضــة يسـيل مسن

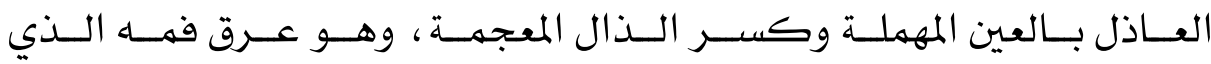

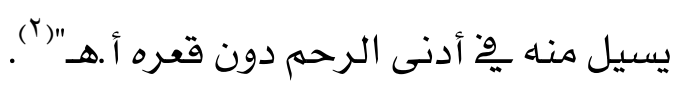

ومــا ذكـــره النــووي: يــراد بــه بيــان الفــرق بـــن دم الحــيض ودم

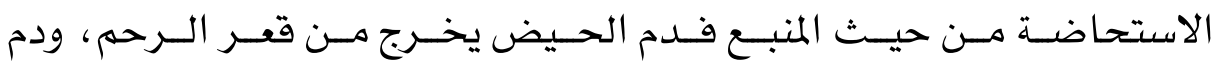

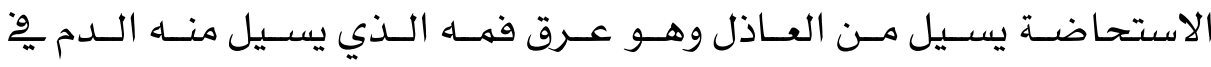

$$
\text { أدنى الرحم دون قعره. }
$$

إلا أن هنــاك فروقة أخـــرى : منهــــا : أن دم الحــيض أســـود

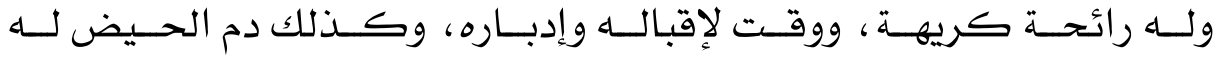

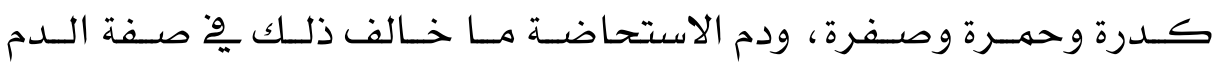

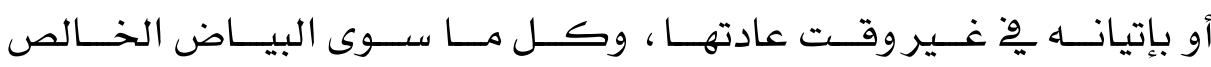

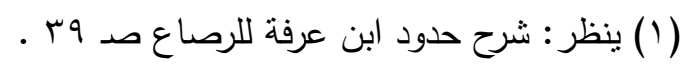

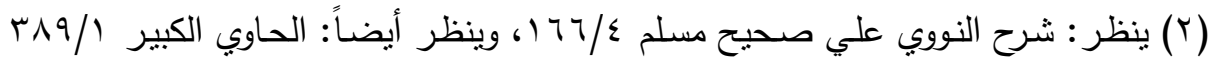

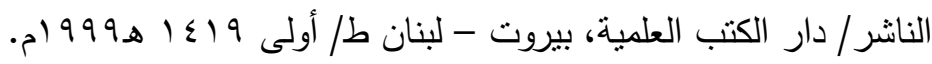




\section{د. عبــــالعظليم مهمسـ أحمهـ}

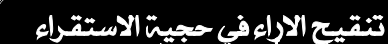

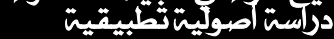

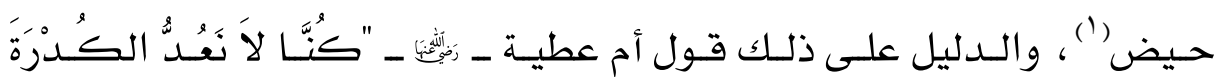

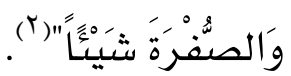

واتقـق العلهـاء علـى أن الـدماء الـتي تخــرج مـن الـرحم علـي ثلاثـة

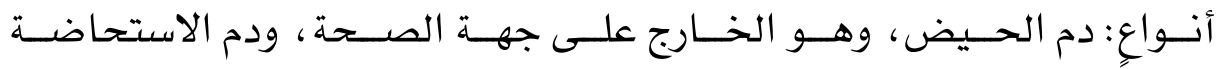

وهو الخارج على جهة المرض، ودم النفاس، وهو الخارج مع الولد (r).

قــال صــاحب الــتلقهن: " والـدمـاء الـتي ترخيهـا الـرحم ثلاثـة : دم

حيض، ودم نفاس، ودم علة وفسـاد وهو الاستحاضة أ.هـ"(£).

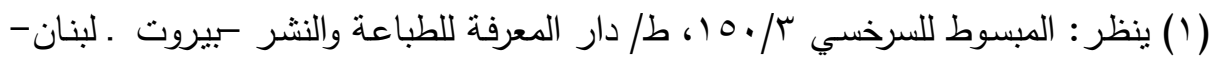

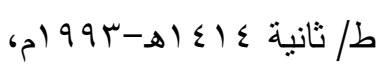

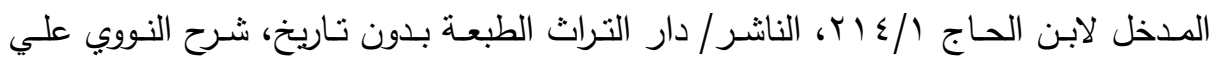

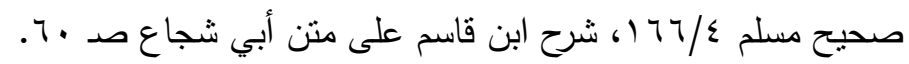

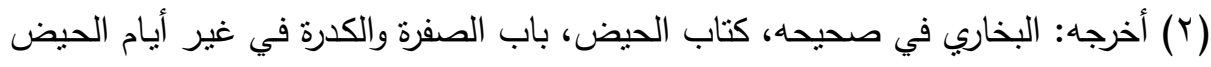

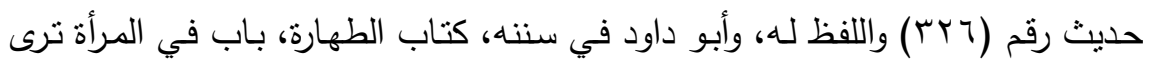

$$
\text { الكدرة والصفرة بعد الطهر حديث رقم (Y. (r). }
$$

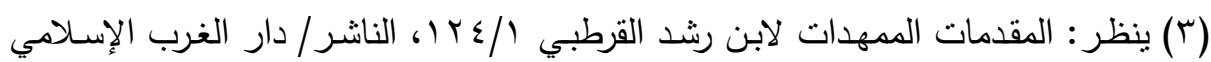

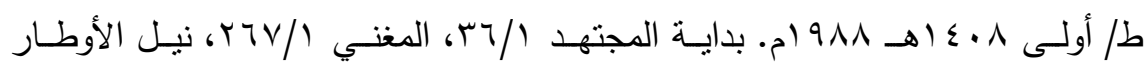
$. r V T / 1$

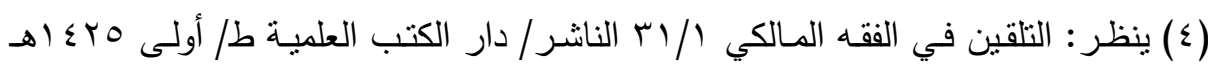

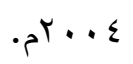




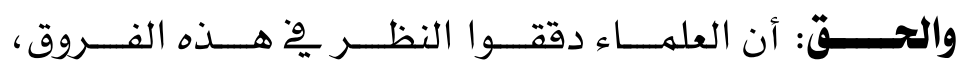

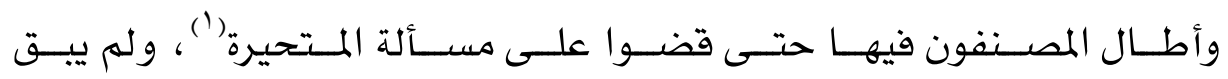
مستصعب أمام هذه الفروق، وهذا هو منهج التشريع الإسـلامي

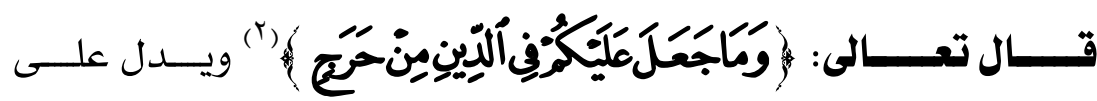

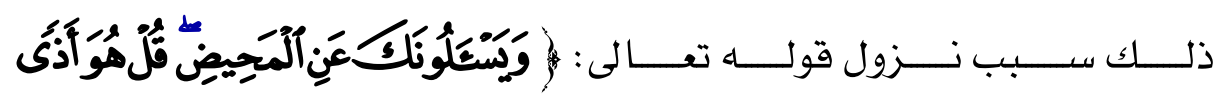

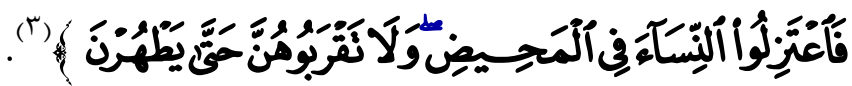

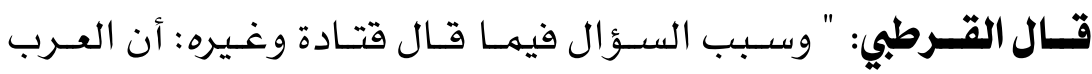

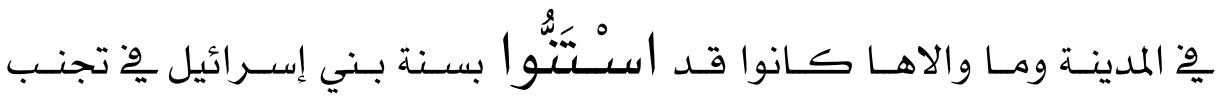

$$
\text { مؤاكلة الحائض ومساكنتها ، فنزلت هذه الآية أ.هـ" (ع). }
$$

وروى مسلمُ بِّ صحيحه عن أنسٍ أن اليهود كانوا إذا حاضت المرأة

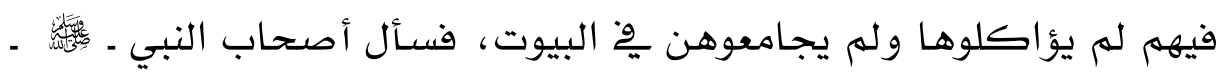

(1) المتحيرة: هي التي لا تميز الدم، ولا كانت لها أيام معلومة، أو كان فنسيتها ولا تعرف

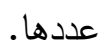

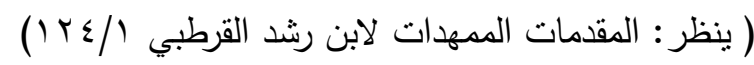

$$
\begin{aligned}
& \text { (Y) سورة الحج الآية (Y^). }
\end{aligned}
$$

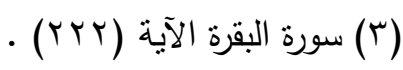

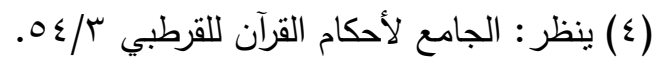




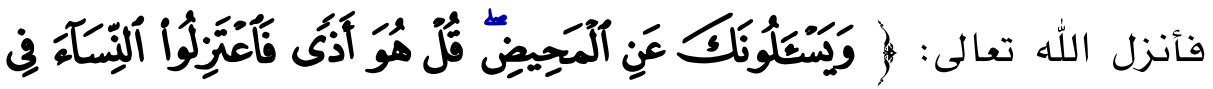

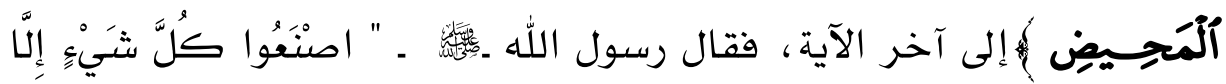
النّّكَاحَ" "(') فبلغ ذلك اليهود فقالوا: ما يريد هذا الرجل أن يدع من أمرنا شيئًا إلا خالفنا فيه (r).

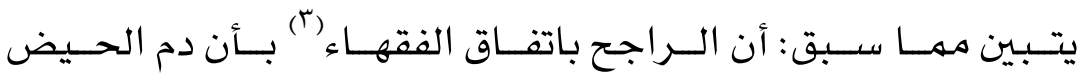

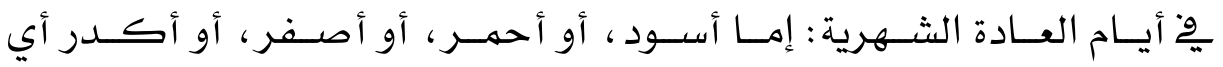

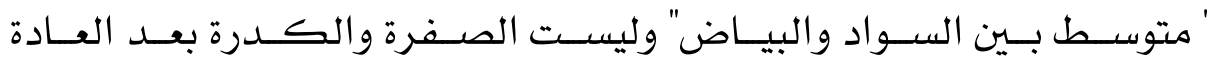
حيضـاً، ولا يعـرف انقطاعــه إلا برؤيـة بيـاض خــالص، بــأن تــدخل المـرأة

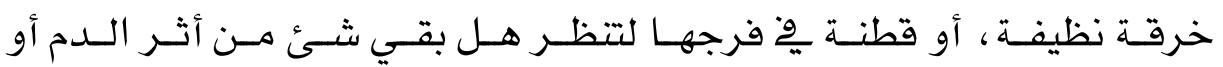

(1) أخرجه: مسلم في صحيحه، كتاب الحيض، باب اصنعوا كل شيء إلا النكاح حديث رقم

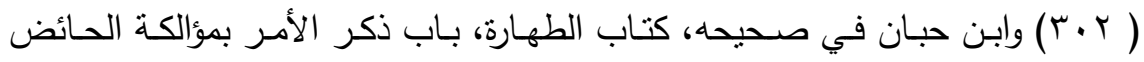

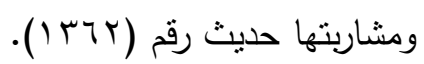

(Y) ينظر : شـرح سنن ابن ماجـه لمغلطاب، كتاب الطهارة، ^^ــــاب مـا جاء في مؤاكلة

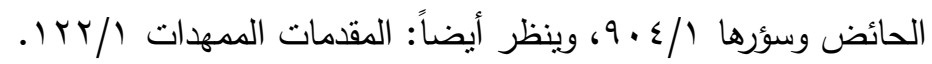

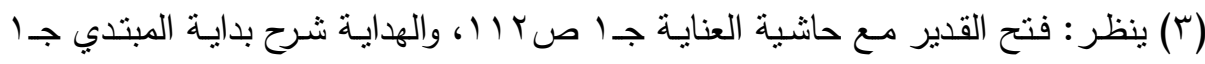

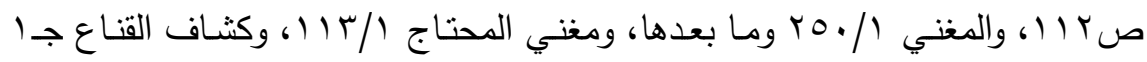

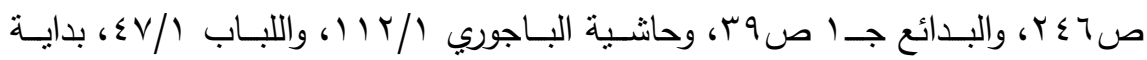
المجتهد إمب وما بعدها. 


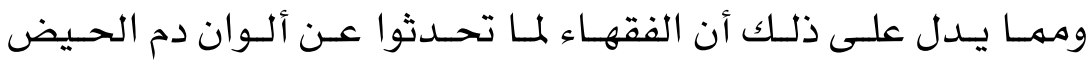

$$
\text { له يختلفوا يخغ ترتيبه كثيراً. }
$$

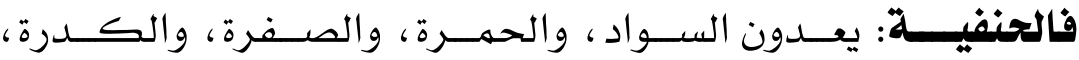

والخضــرة مــن ألــوان دم الحــيض. إلا أن الخضـــرة إذا كـانـــ المـــرأة مــن

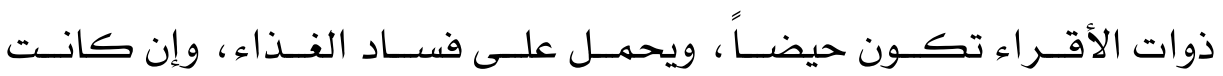

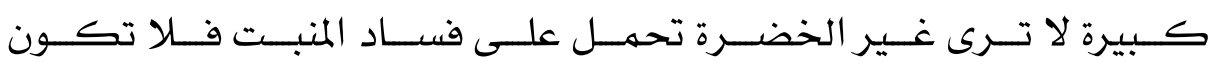

حيضاً (')

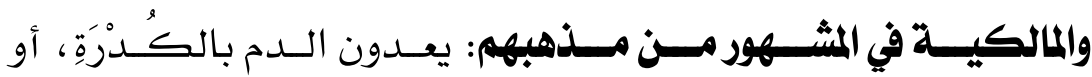

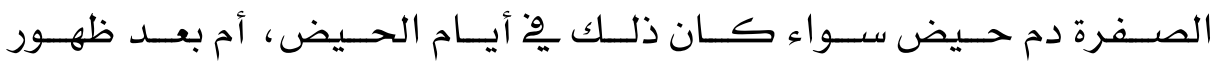

$$
\text { علامة الطهر (r) علمر }
$$

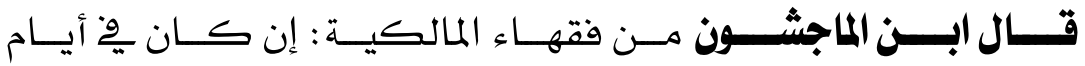

المحــيض فهـو دم حـيض وإلا فـلا ، وبـهـ قـال بعض المالكيـة أيصـاً ، ويـرى

البعض من المالكية : أنه ليس بدم حيض مطلقاً (r).

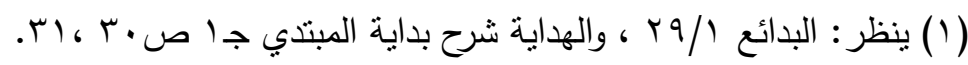

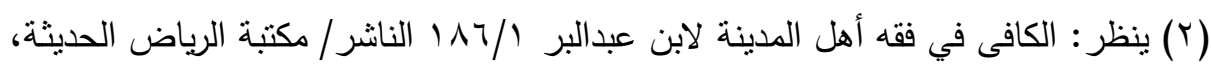

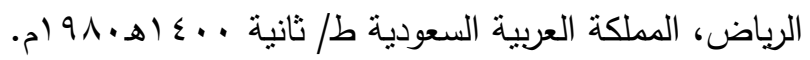

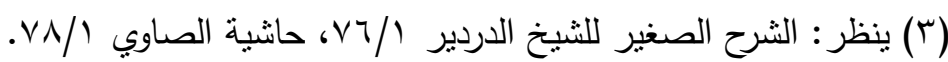


والشــــافعية: يعــدون ألــــوان دم الحـيض بحســب قوتهــا فقــالوا:

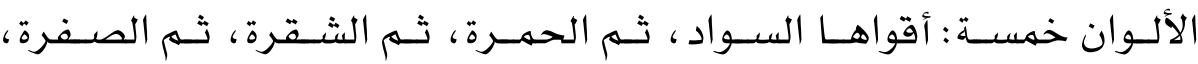

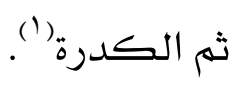

والحنابلــــة يــرون: أن المــرأة إذا رأت ِِّ أيــام عادتهــا صـفرة ، أو

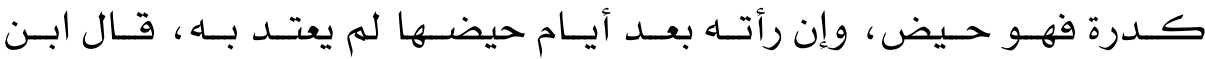

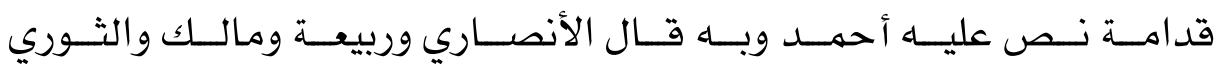

$$
\text { والأوزاعي وعبد الرحمن بن مهدي والثـافعي وإستحاق(ب). }
$$

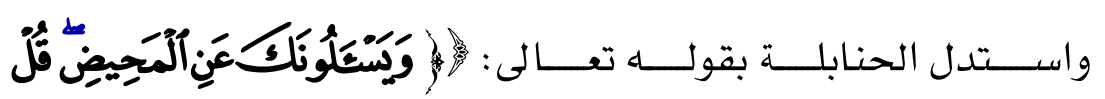

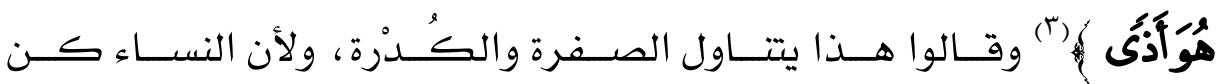

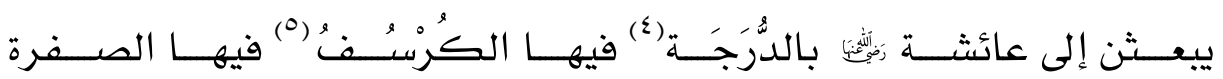

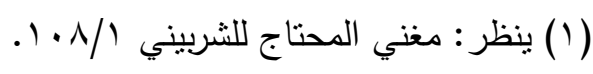

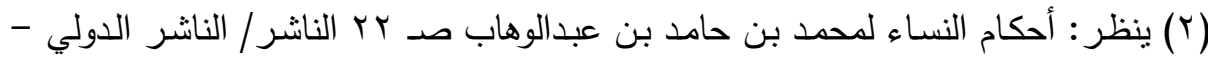

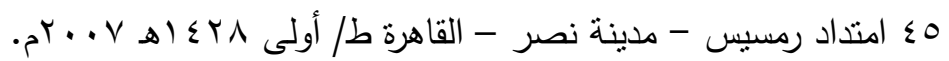

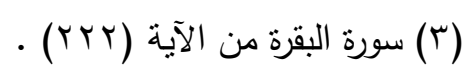

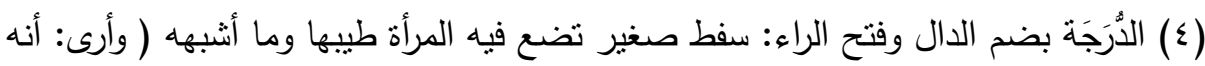
يشبه الصندوق الصغير في عهدٍ قريب، وقد يحل محله حقيبة اليد اليوم ). (0) الكُرسنف: بضم الكاف والسين: القطن. ( بنظر : تعليق مصطفى البغا على الحديث في صحيح البخاري، كتاب الحيض، باب إقبال

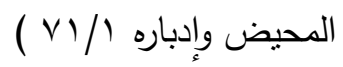




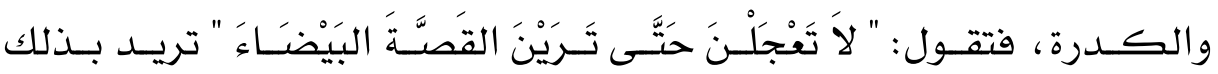

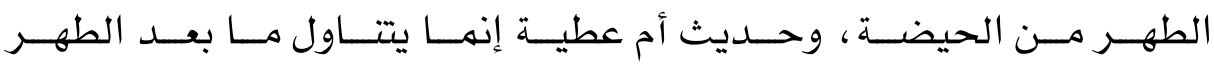
والاغتسال، وقال ابن قدامة " ونحن نقول به" ('.

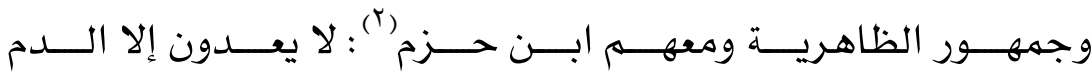

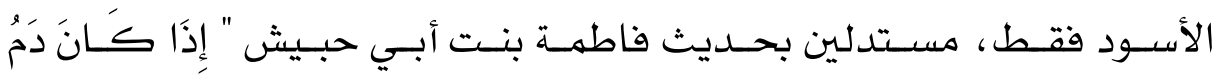

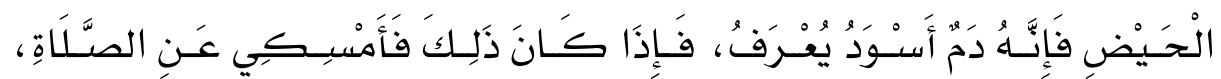

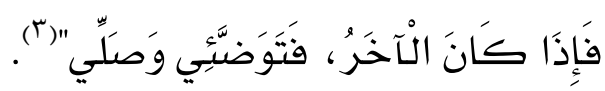

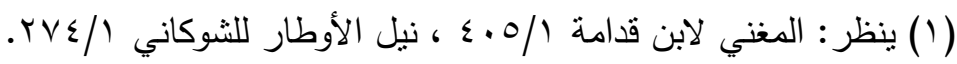

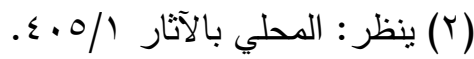

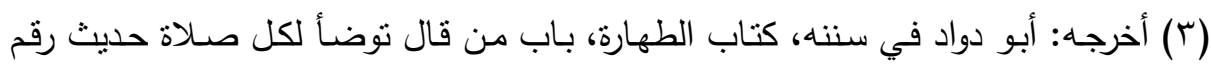

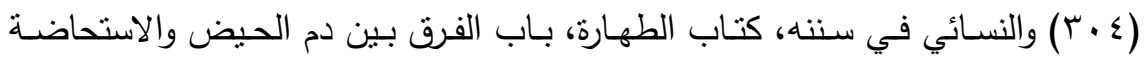

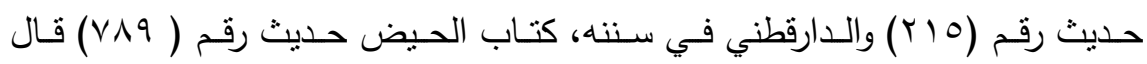
الألباني: حسن صحيح. وقال الذهبي في المستدرك: صحيحٌ علي شرط مسلم. 


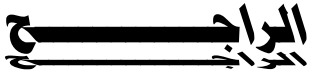

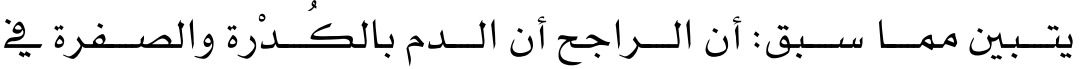

أيــام الحــيض يعــد دم حــيض، وبعــد أيــام الحــيض لا يعــد دم حسـيض،

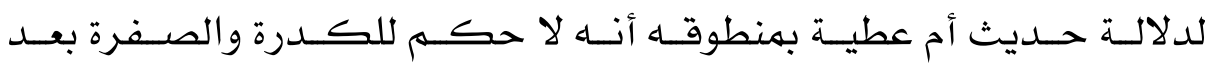

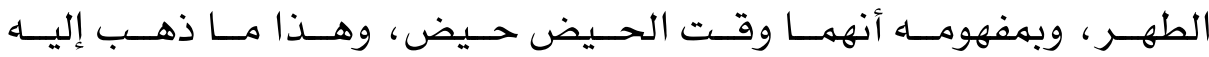
جمهــور العلهــاء، وإن كــان الإمــام أبــو يوســف، وروايــة عـن النـاصــر، والشافعي أنهما بعد أيام الدم حيض؛ لأنهما من أثاره لا قبله (').

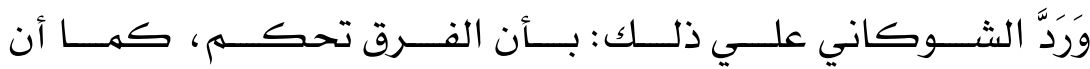

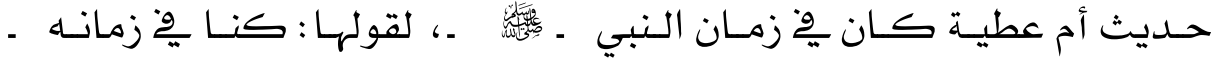

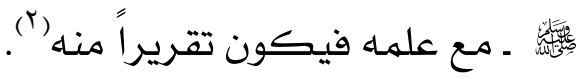

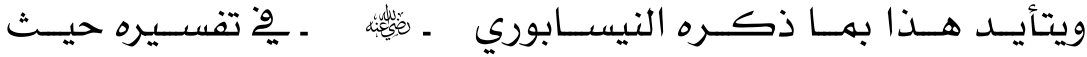

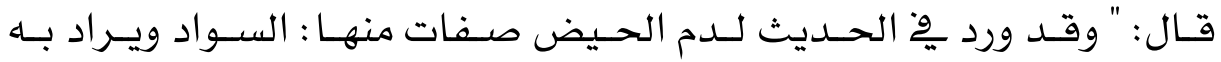
أنـــاه يعلــوه حمــرة متراكبــة فيضـــرب مــن ذلـــك إلى الســـواد ، ومنهــــا :

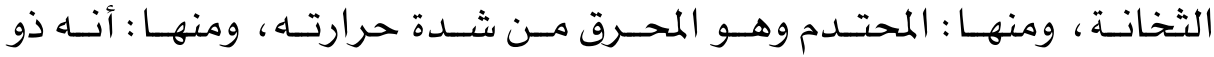
دفعـات أي يخـرج برفـق ولا يسـيل ســيـلا، ومنهـــا : أن لــه رائحسة كريهـة ،

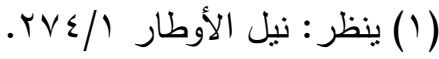

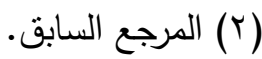




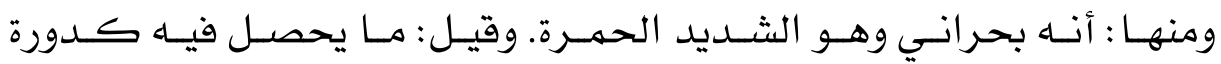

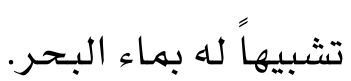

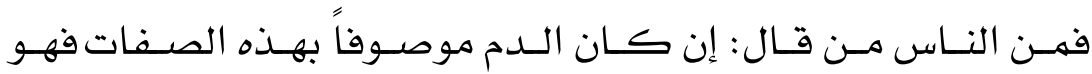

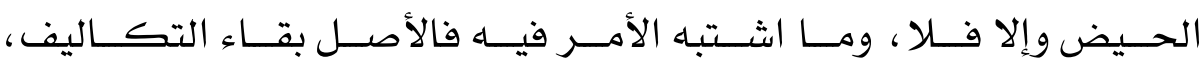
وزوالهـا إنهــا كــان بعـارض الحـيض، فـإذاذ كــان غـير معلـوم الوجـود

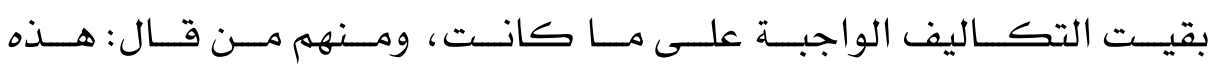

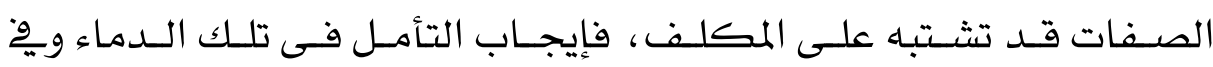

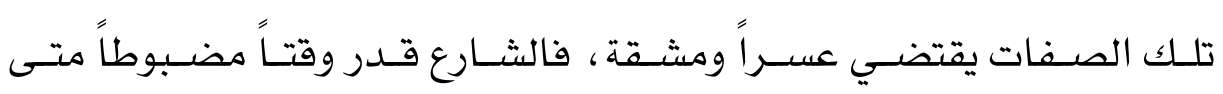

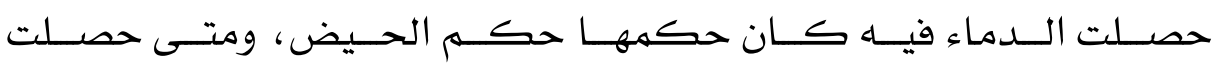

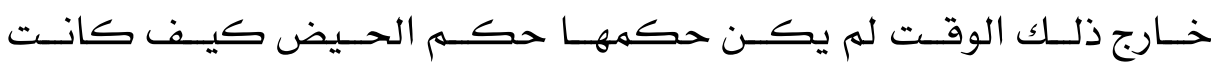
صفة تلك الدماء أ.هـ (').

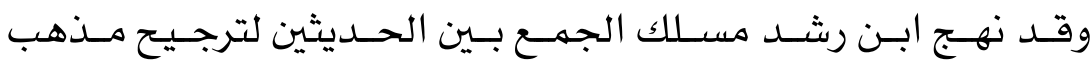

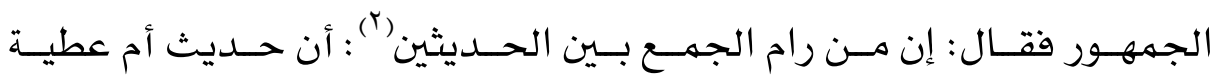

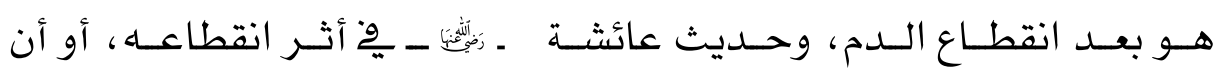

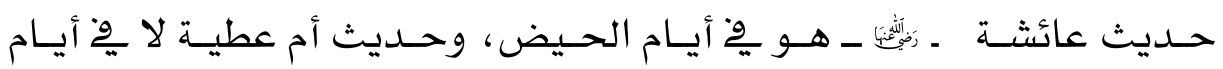

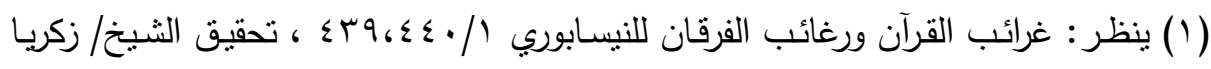

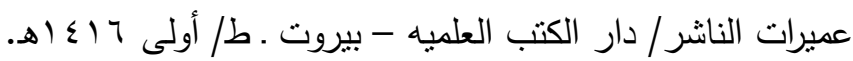

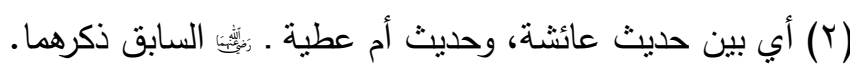




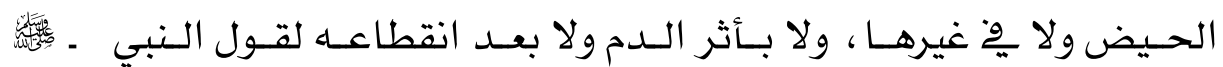
ــ لفاطهــة بـــت أبــي حبـيش، أنهــا كانــت تسـتحاض " إذا كــان دم الحيضــة فإنـاه دم أســود يعـرف. فـإذا كـان ذلـك فأمســكي عـن الصـلاة ،

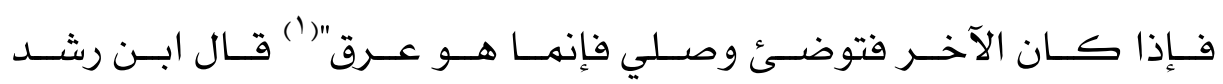

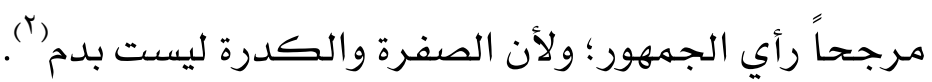

\section{آراء العلماء فيه أقلز الهيضض وأكثره}

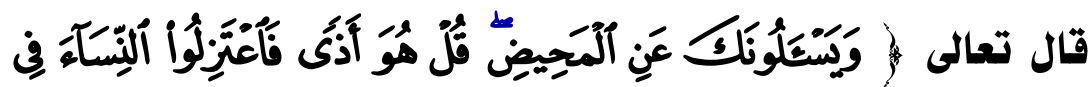

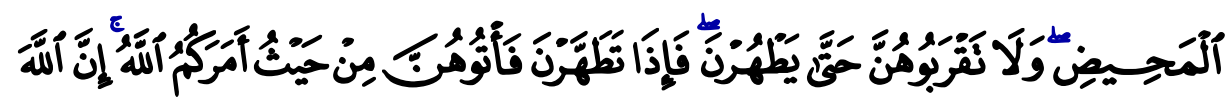

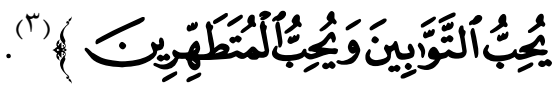

أولاً: اتفق العلماء على أن الدم لا يكون حيضاً إلا إذا كان بالألوان

$$
\text { السابق ذكرها. }
$$

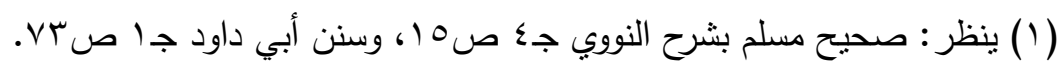

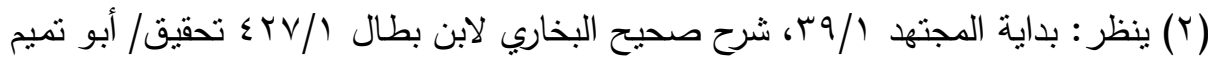

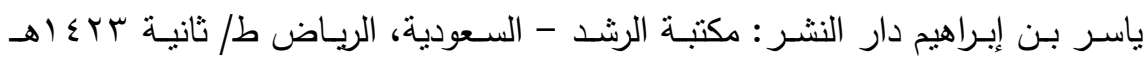

$$
\text { بr }
$$

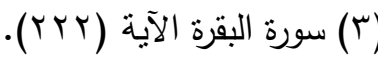

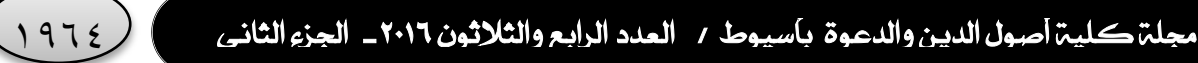


ثانيا: واتفقوا كذلك على أنه لا بدَّ أن يتقدمه أقل مدة الطهر وهي خمسة عشر يوماً عند الجمهور، وأن يبلغ أقل مدة الحيض، وهي مختلف فيها بين الفقهاء، وما نقص عن مدة الحيض أو زاد على أكثرها فهو استحاضة.

ثالثاً: اختلف العلماء ِِِّ أقل الحيض وأكثره إلى أربعةِ مذاهب هي: المذهب الأول: وإليه ذهب الحنفية ومن معهم حيث يرون أن اقلَّ الحيض ثلاثة أيام ولياليها، وما نقص عن ذلك فهو استحاضة، وقال أبو يوسف من الحنفية: إنه يومان والأكثر من اليوم الثالث إقامة للأكثر مقام

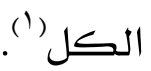

المذهب النانـي: وإليه ذهب المالكية ومن معههم حيث يرون أن أقلَّ أيام الحيض لا حد لها، بل قد تكون الدفعة الواحدة عند الإمام مالك حيضاً، وباه قال ابن حزم (r) ، بل إن اللمعة حيضٌ كها يرى ابن رشد القرطبي، إلا أنه لا يعتد بها بِّ الإقراء ِِّ الطلاق، فأقله عند المالكية دفقة، أو دفعة وِ لحظة فتعتبر حائضاً وتفتسل بانقطاعه، ويبطل صومها

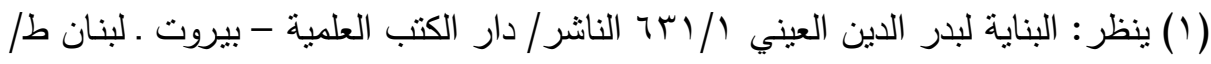

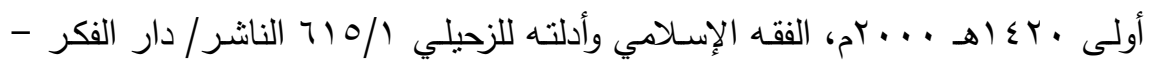

$$
\text { سوريَّة - دمشق . اله }
$$

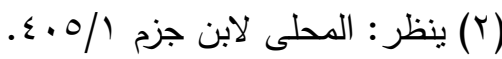


وتقضي ذلك اليوم، وأما بالنسبة للعدة ، والاستبراء فأقله يوم، أو بعض يوم

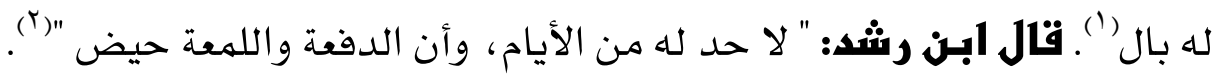

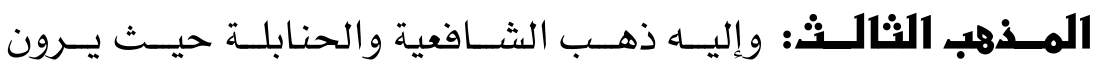
أن أقـلَّ الحــيض يــوم وليلــة ، أي : أربــعْ وعشــرون ســـاعة علــي الاتصـــال

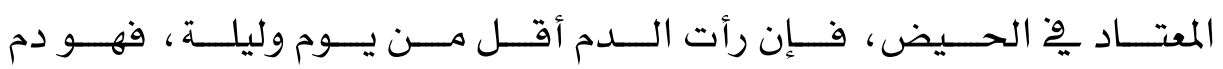
استحاضــة، لا دم حـيض ، وبـه قـال علـي بـن أبـي طالـب، وعطـاء بـن أبـي رباح، وإسحاق، وأبو عبيَيْدٍ، (r).

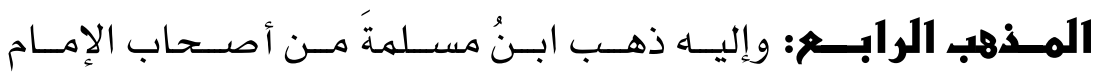

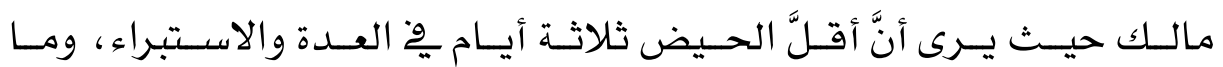

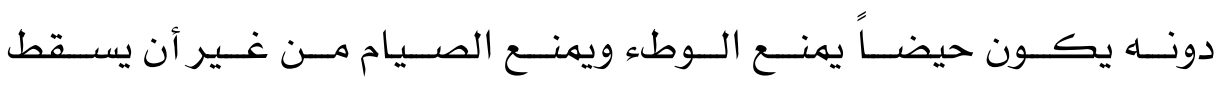
وجوبه ، ويهنع الصلاة ويسقط وجوبها (؛).

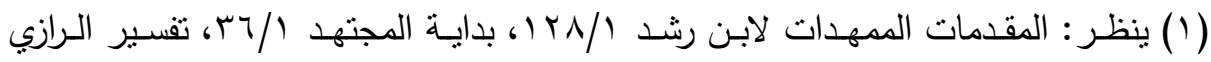

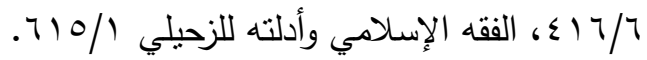

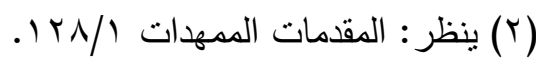

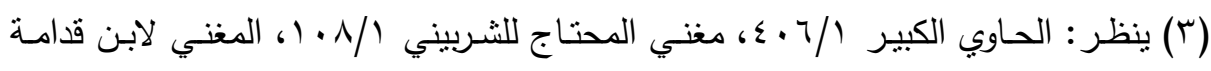

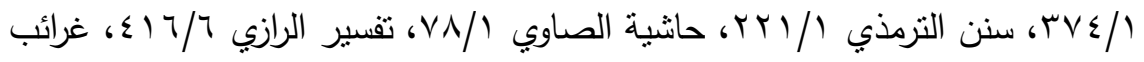
القرآن ورغائب الفرقان للنيسـابوري // • ع ـ ومـا بعدها، الفقه الإسـلاهي وأدلته للزحيلي $.717 / 1$

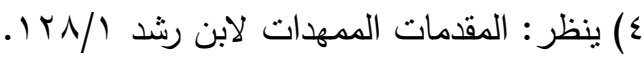




$$
\text { أولاً: أدلة المذهب الأول وهم الحنفية: }
$$

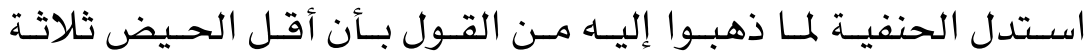

أيام ولياليها ، وما نقص عن ذلك فهو استحاضة بها يأتي:

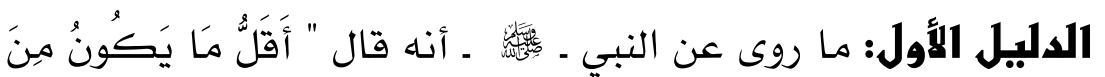

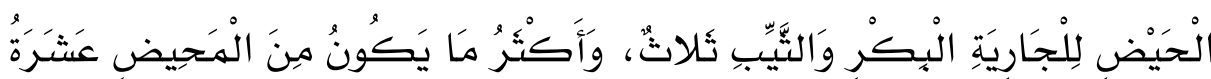

(أيَّامِ ") (1)

\section{وهه الدلالة من الهديثن:}

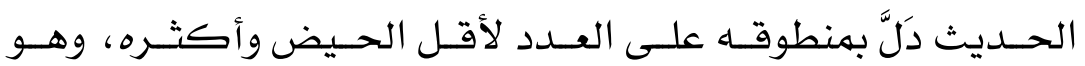

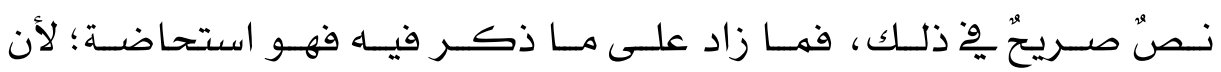

$$
\text { تقدير الشرع يهنع إلحاق غيره باه. }
$$

المناقشتــة : نوقش هذا الدليل: من وجهين:

( (1) أخرجه: الدار قطني من حديث أَبِي أُقَّامَةَ، كتاب الحيض حديث رقم ( 1 (1 ) وقال: عبد الملك هذا رجل مجهول، والعلاء هو ابن كثير وهو ضعيف الحديث، ومكحول لم

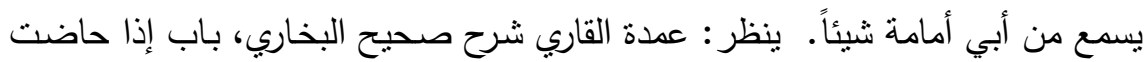

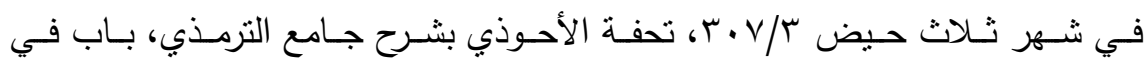

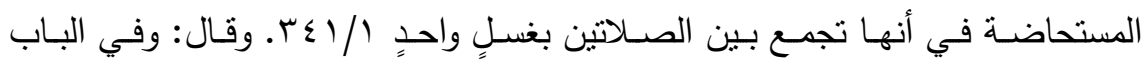

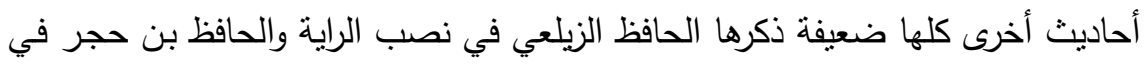

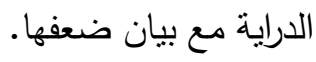




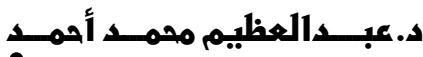

الوجه 1الأول: أن ذكر الحيض ورد بِّ الشرع مطلقاً من غير تحديد ،

ولا حدَّ لهه ِِّْ اللغة، فَرُجعَ فيه إلى العرف والعادة كالقبض والإحراز والتفرق، وقد وُجدَ حيضٌ أقل من ثلاثة وأكثر من عشرة، فقد روى عن عطاء: قال رأيت من النساء من تحيض يوماً وتحيض خمسة عشر يوماً ، وروىى عن شريك قال: عندنا امرأة تحيض كل شهر خهسة عشر يوماً حيضاً

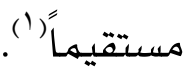

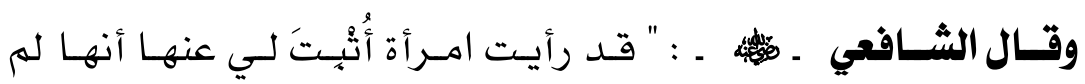

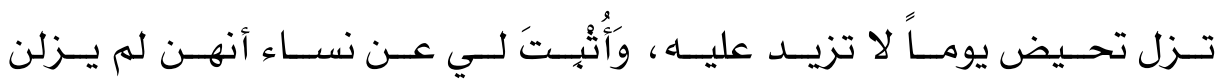

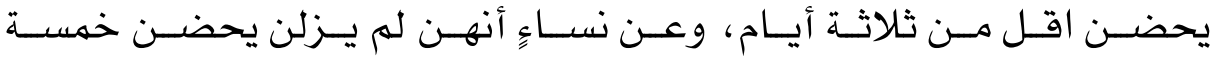

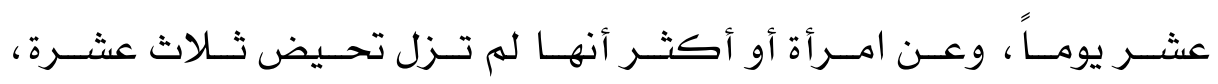
فكيف زعمت أنه لا يكون ما قد علمنا أنه يكون؟"(ك).

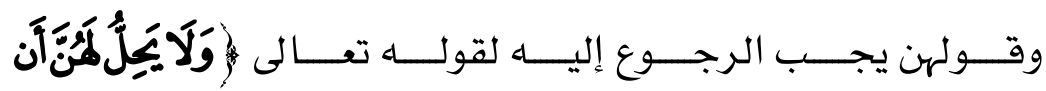

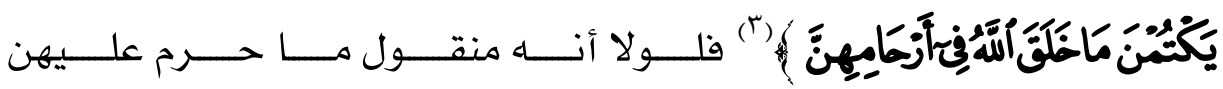

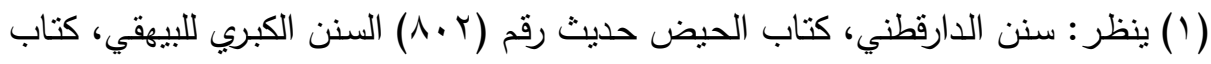

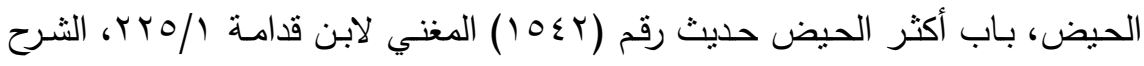

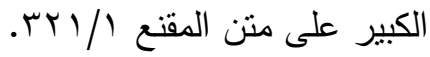

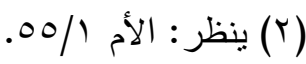

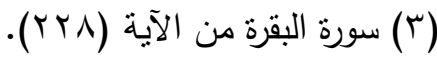




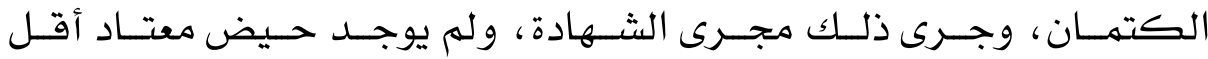
من ذلك يٌْ عصر من الأعصار فلا يكون حيضاً بحال.

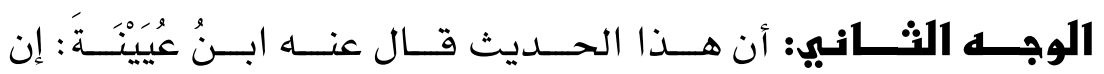

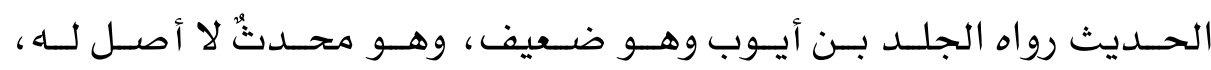

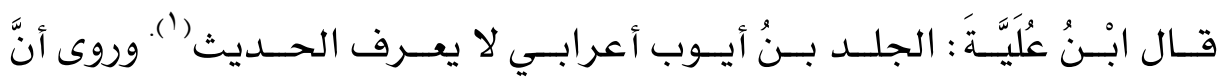

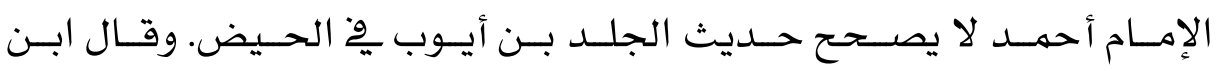

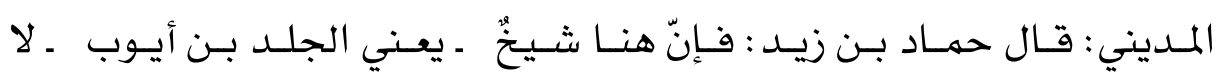

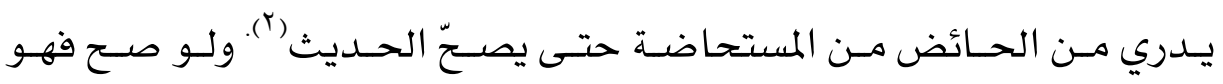

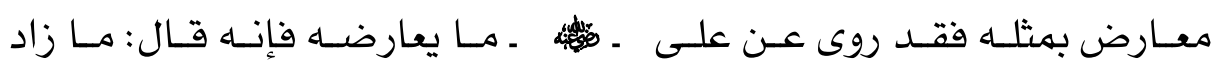
على خمسة عشر استحاضة وأقل الحيض يوم وليلة (َ).

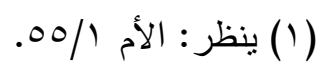

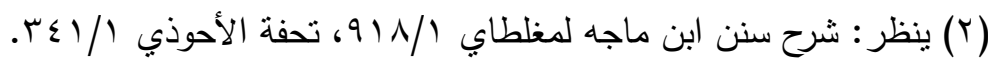

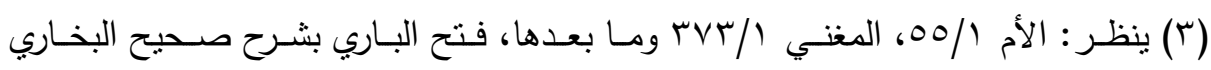

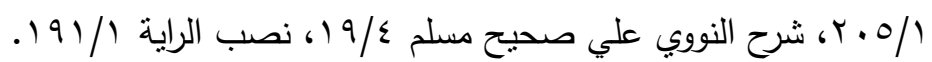




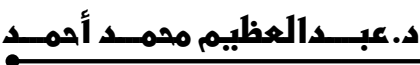

تنقيع الإراء في حيويت الأستقراء سلات

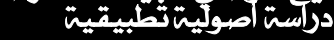

الــليل النــانـي: مـا روى عـن أنسِِ بـن مالـك، وعثمــان بـن أبـي

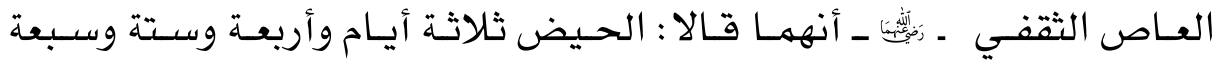
وثمانية وتسعة وعشرة، وما زاد فهو استحاضةً (').

\section{والاستتدلال بـهذا من وجهين:}

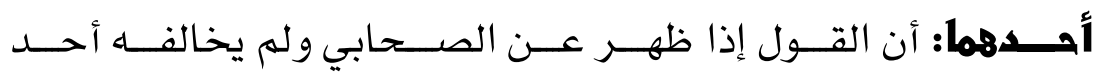

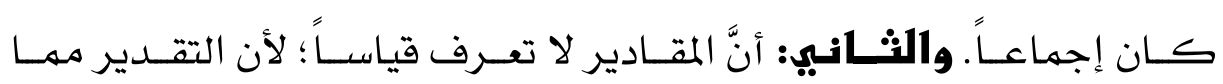
لا ســبيل إلى العقـل إليــه متــى روي عـن الصــحابي، فالظــاهر أنــه سمعــه (r) - من الرسول - (r)

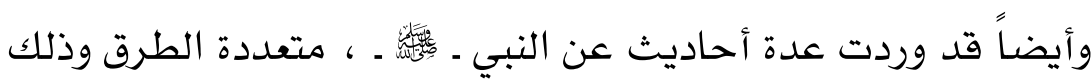
يرفع الضعيف إلى الحسن، وكها سبق أن المقدرات الشرعية لا تدرك بالرأي فالموقوف فيها حكمه الرفع، بل تسكن النفس بكثرة ما روى فيه عن الصحابة والتابعين (r) (2)

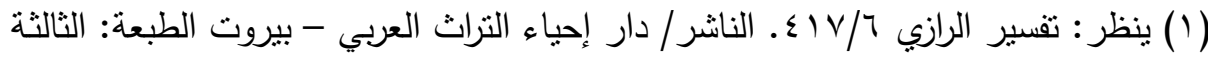

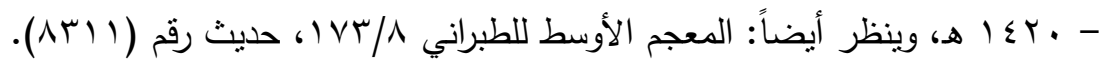
(Y) ينظر : تقسير الرازي (Y)

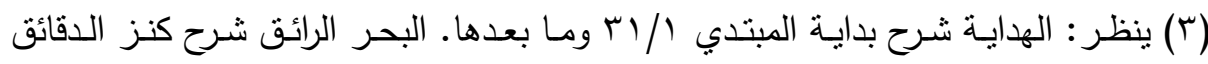

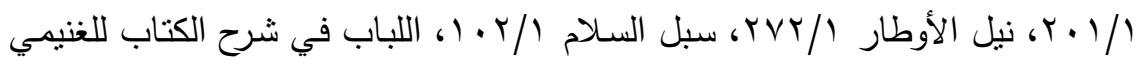

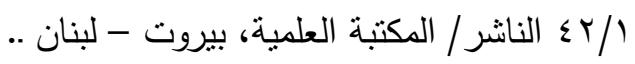


المناقشثـة: نوقش هذا الدليل من وجهين:

الوجه الأول: بأن هذا القول من الصحابي معارض بهثله عن علىَّ .

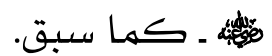

الوجه الفنانيه: أنه يهكن الجهع بين القولين بأن ما روى عن على ـ.

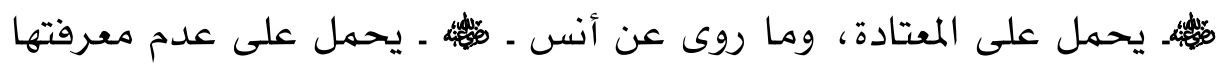

$$
\text { لعادتها وعدم إمكان التمييز بصفات الدم. }
$$

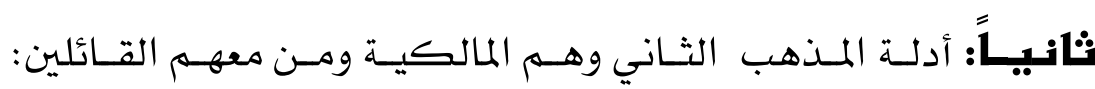

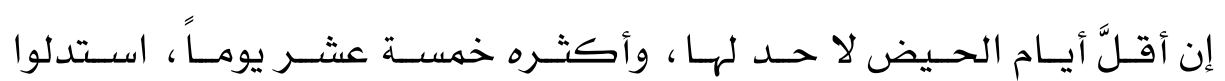

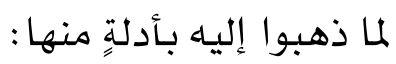

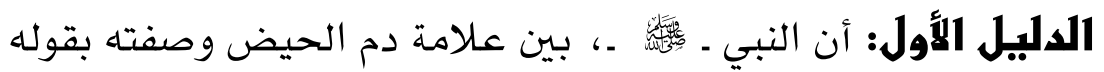

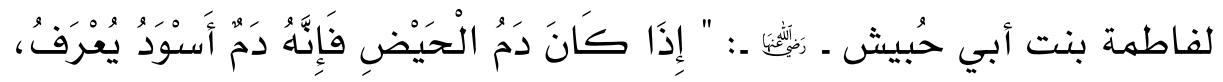

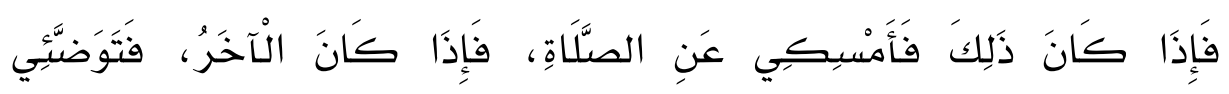

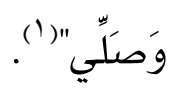

وجه الدلالة من المديث: أنه متى كان الدم موصوفاً بهذه الصفة

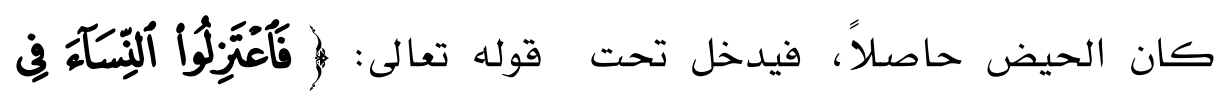




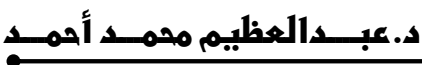

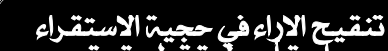

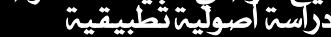

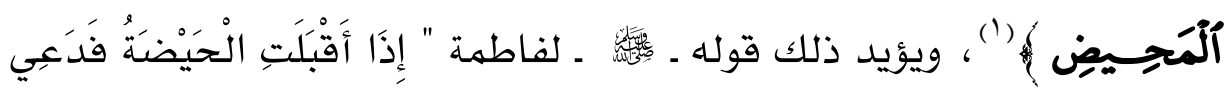

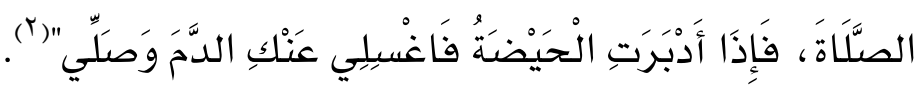

قََالَ سُفْيَانُ: وتفسيره إذا رأت الدم بعدما تغتسـل أن تغسل الدم

فقط "r).

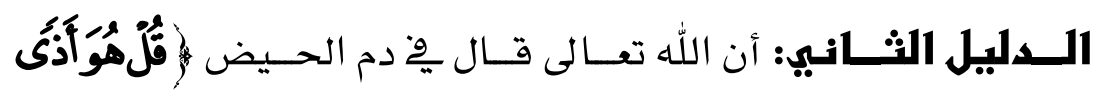

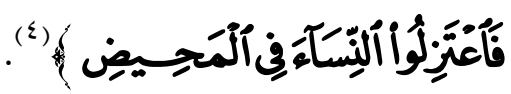

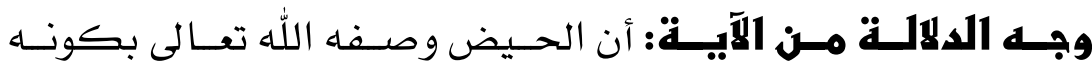

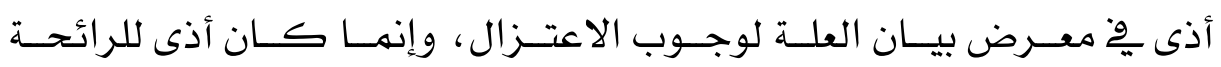

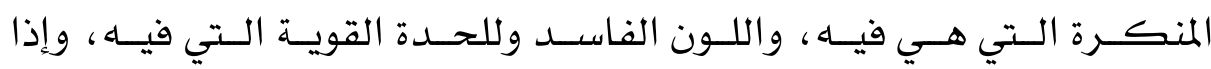

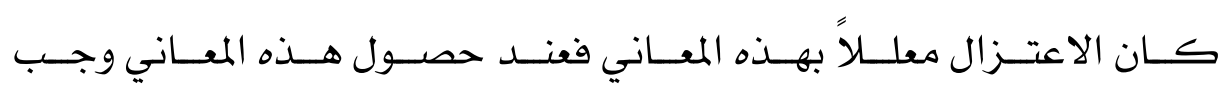

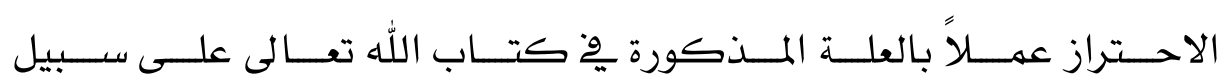

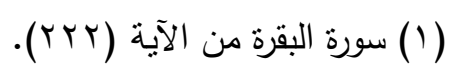

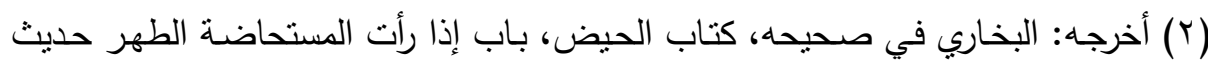

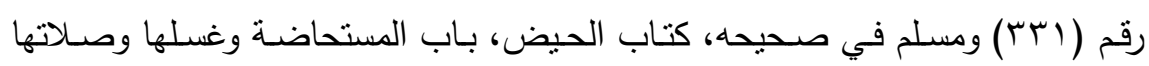

$$
\text { حديث رقم (rTrr). }
$$

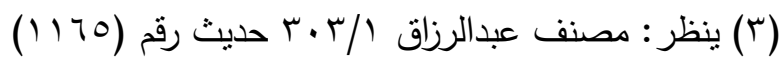

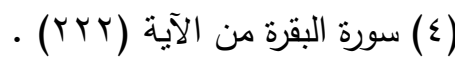




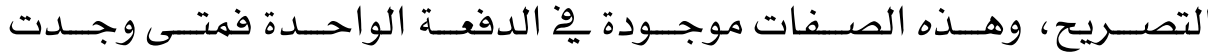

الصفات المذكورة فهو حيض (').

\section{المنـاقشــة:}

\section{نـوقشر مـا اسـتندل بـه أصـاب المـذهب الفنانـي: بأنـه لـو كـان}

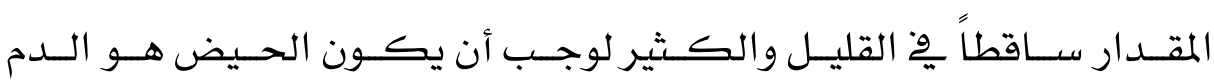

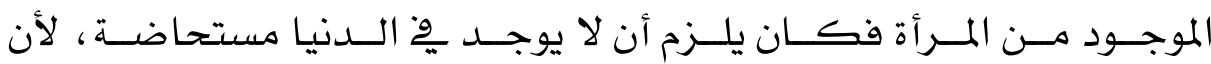

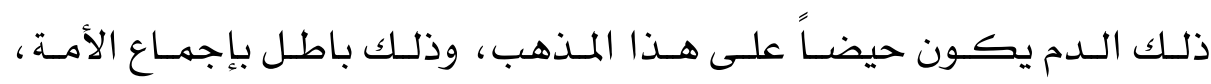

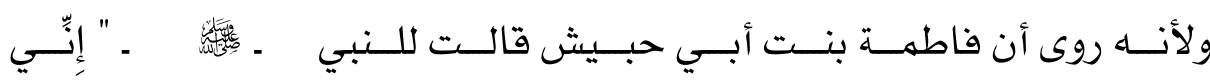

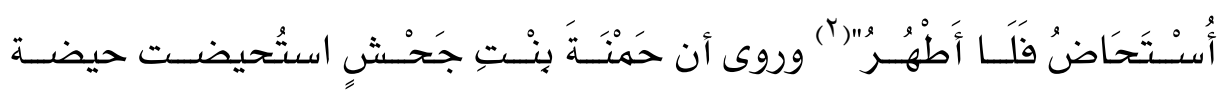

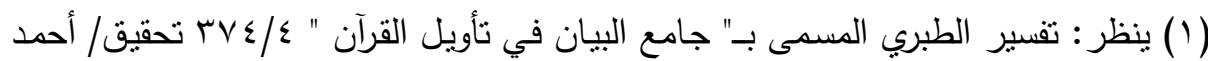

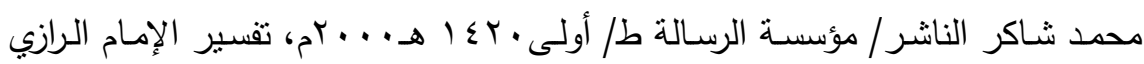

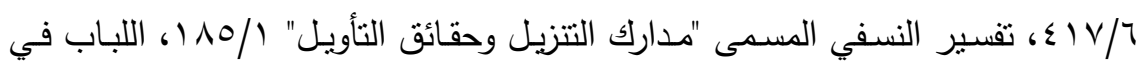

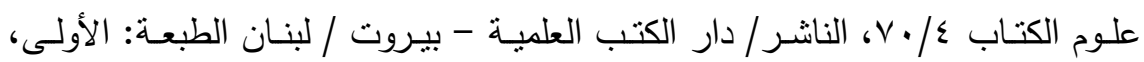

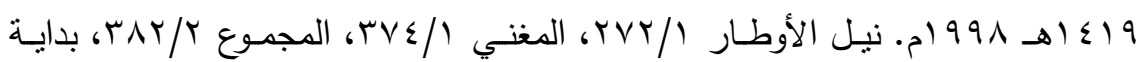

$$
\text { r) سبق تخريجه. }
$$




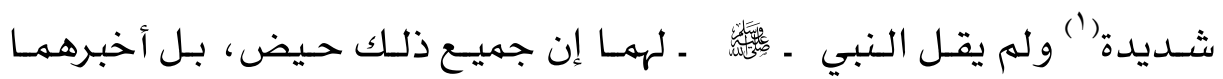
أن منـه ما هو حيض ومنهه ما هو استحاضة فبطل هذا القول(r).

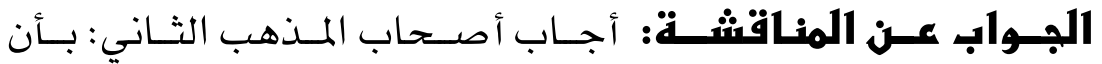

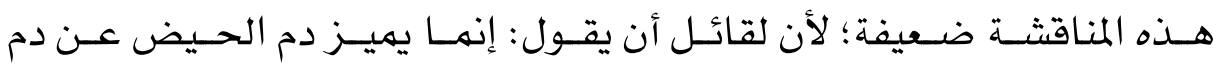

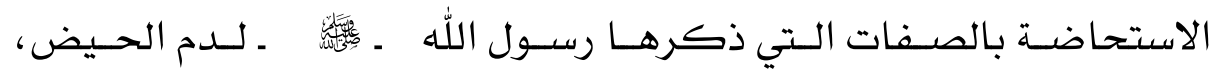
فـإذا علمنــا ثبوتهـا حكمنــا بـالحيض، وإذا علمنــا عـدمها حكمنــا بعـدم

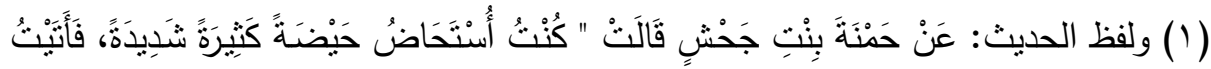

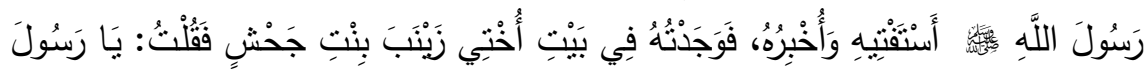

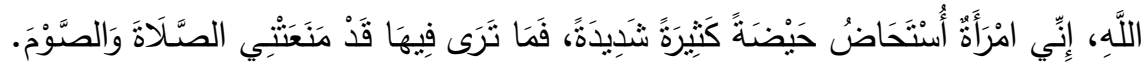

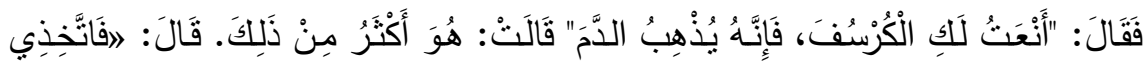

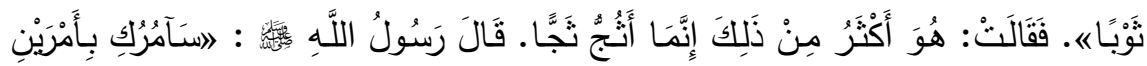

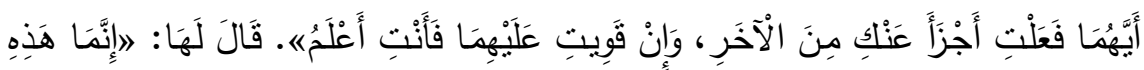

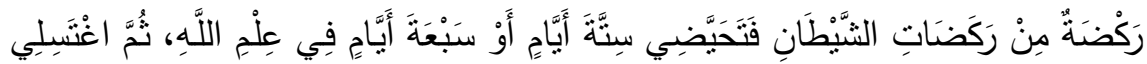

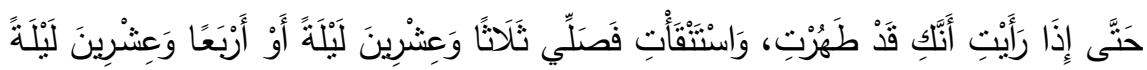

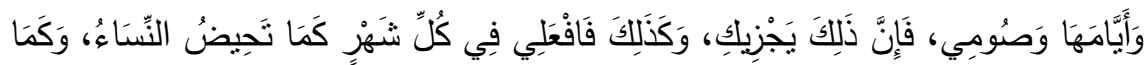

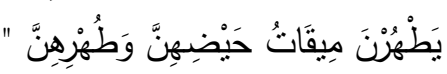

( أخرجه: أبو داود في سننه، كتاب الطهارة، باب من قال إذا أقبلت الحيضـة تدع الصـلاة

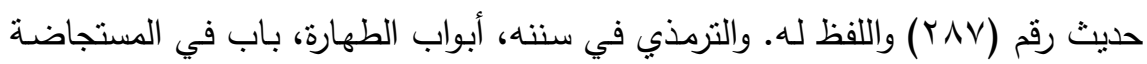

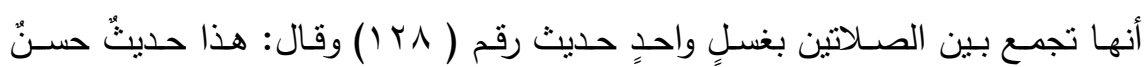
صحيحُ.

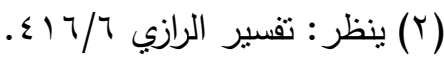




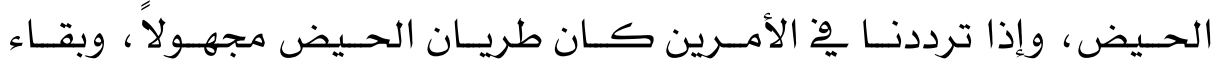

التكليـف الـذي هــو الأصـل معلـوم، والمشــكولك لا يعـارض المعلـوم، فـلا

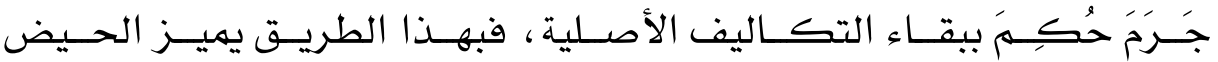
عن الاستحاضة وإن له يجعل للحيض زمان معين (').

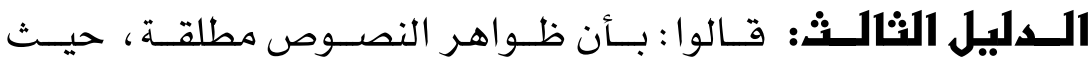

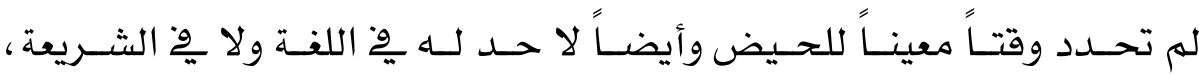

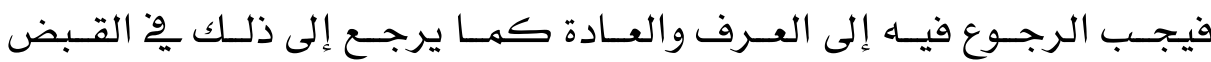
والإحراز والتفرق وأشبـاهها.

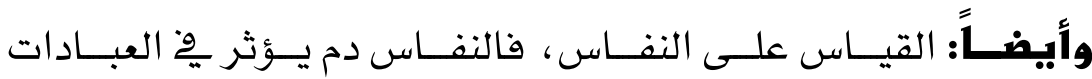

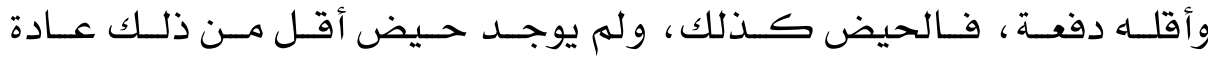
مستهـرة يخ عصر من الأعصار فلا يكون حيضاً بحال (r).

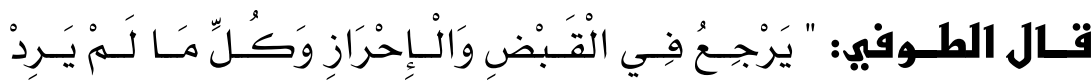

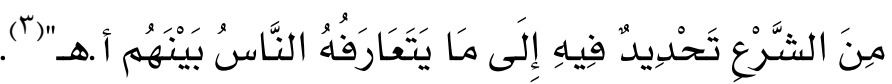

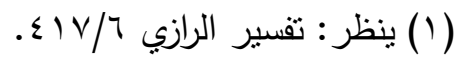
(Y) ينظر : تحفة الأحسوذي /Y/

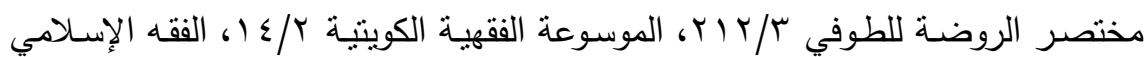
وأدلته للزحيلي الج/ الناشر/ دار الفكر - سورية - دمشق ..

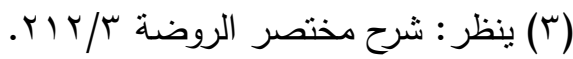


الـــليل الرابــــو: واســتدلوا أيضــاً بالاســتقراء فقــالوا : إن مــن

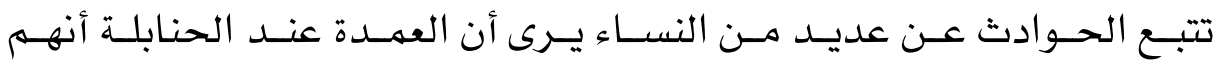

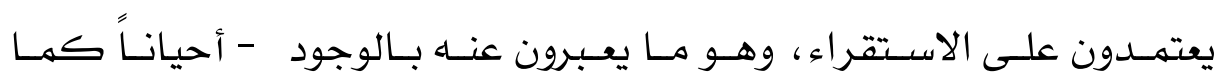
ذكــروا بِِ اسـتدلالهم لأكثَر الحهـل، ولعـل إطلاقهـم العـرف والعـادة هنا بهذا المعنى، وكذلك المالكية('). ويتأيـــد هـــا بهـــا ذكــره القــرطبي معزيــاً إلى الأوزاعـي: قـــال

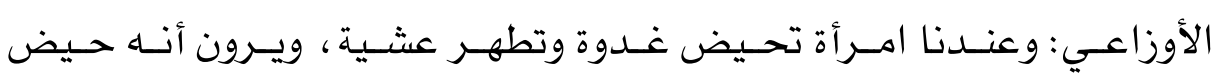
تدع لله الصلاة) (؟) ثالثاً: أدلة الإمام الشافعي ومن معها: القائلون بأن أقلَّ الحيض يومُ وليلة، وأكثره عشرة أيام، استدل بأدلة كثيرة منها:

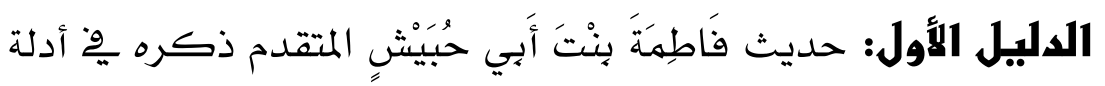
المالكية)

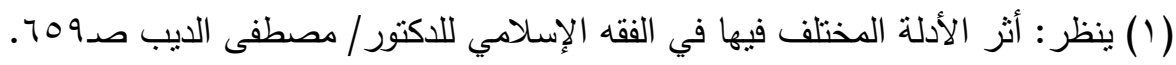

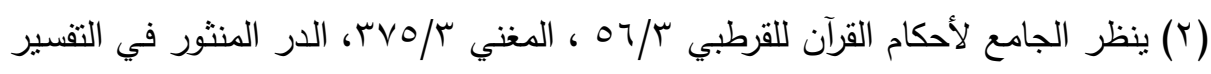

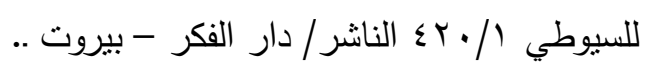

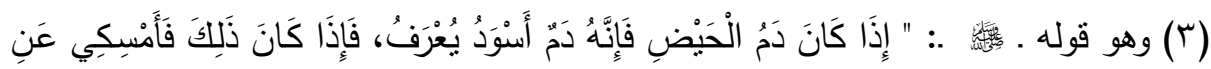

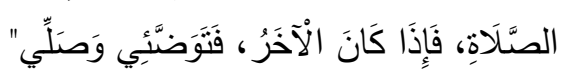




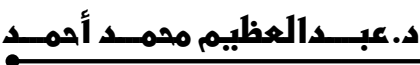

تنقيع الإراء في حيويت الإستقراء سلان

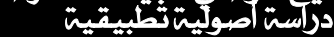

وجه الدلالة من الهديث: قالوا: إنَّ هذه الصفة موجودة بِّ اليوم

والليلة ، فإذا وجد ذلك الدم پِّ اليوم وليلته فقد حصل الحيض، فيدخل تحت

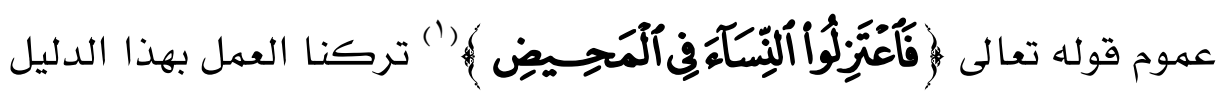
وِّ الأقل من يوم وليلة، وِوْ الأكثر من خمسة عشر يوماً بالاتفاق بيني وبين

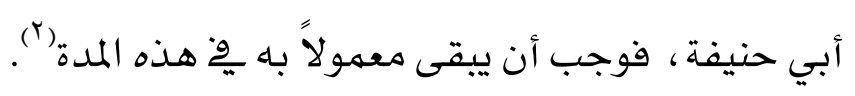

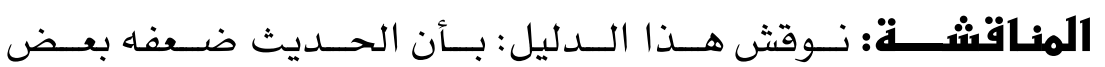

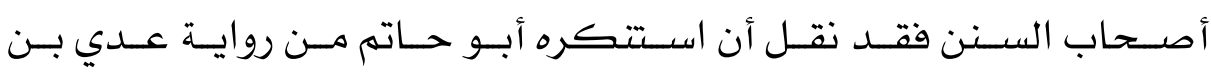
ثابـت عـن أبيـهـ عـن جـده وجــده لا يعـرف، وضـففه أيضـاً أبـو داود (r) وقـال

الدارقطني يُّْ العلل: أسنده عنبسة عن فاطهة ولم يتابع على ذلك(ع).

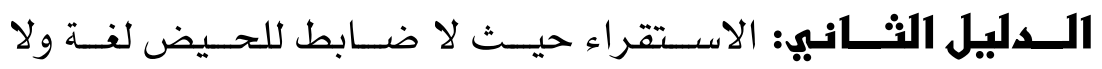

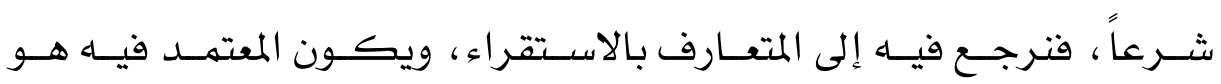

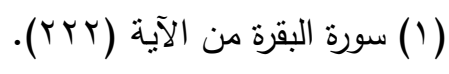

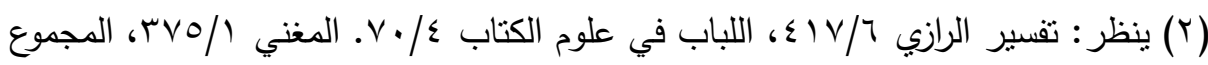

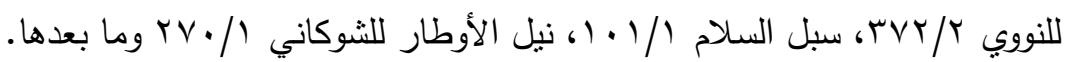

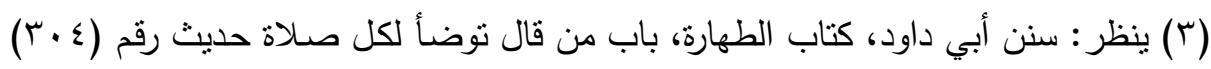

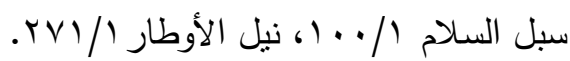

$$
\begin{aligned}
& \text { ينظر : العلل للدارقطني v/0.1. }
\end{aligned}
$$




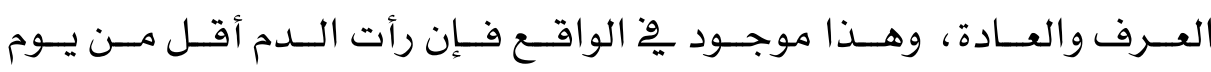

$$
\text { وليلة فهو دم استحاضة ، لا دم حيض. }
$$

قــال النــووي: ومــن الاســتقراء أن ذلــك موجــود ومشـــاهد ، ومــن

أظرفـه مـا نقلـه أبـو الطيـب يخّ تعليقـه قـال : أخـبرتني امـرأة عـن أختهـا أنهـا

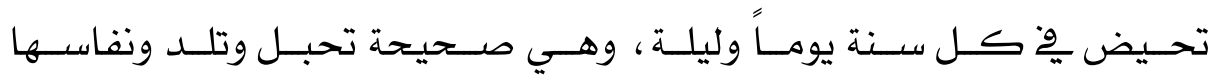

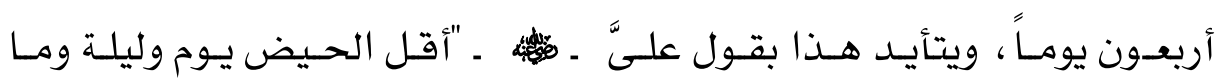
زاد على خمسـة عشر استحاضة" (').

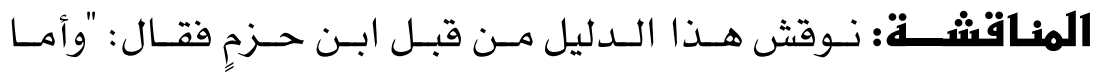

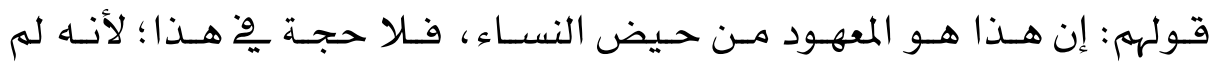

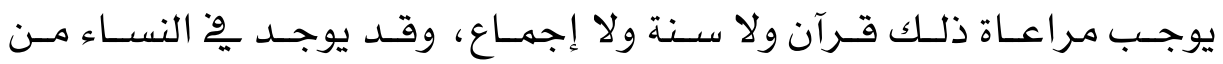

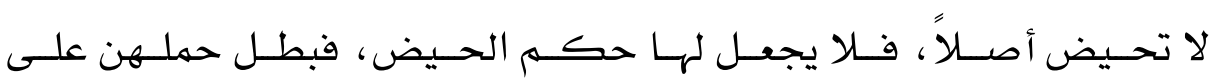
المعهود ، وقد يوجد من تحيض أقل وأكثر، فسقط هذا القول(؟).

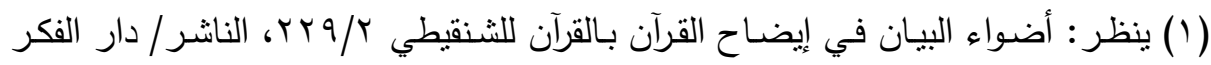

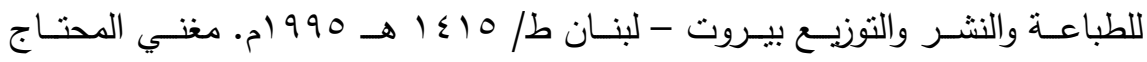

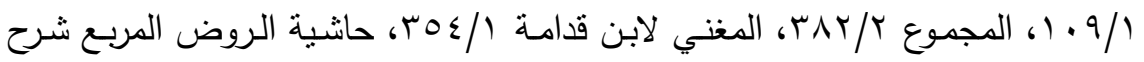

زاد المستقنع / / דVT هامش (Y).

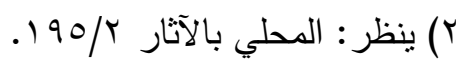




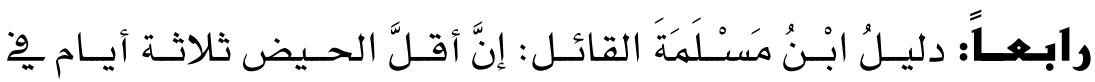

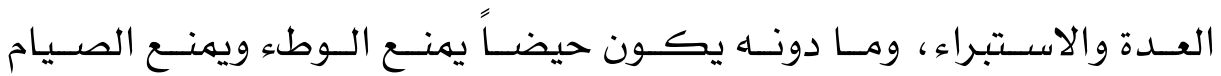
من غير أن يسقط وجوبهاه، ويمنع الصلاة ويسقط وجوبها.

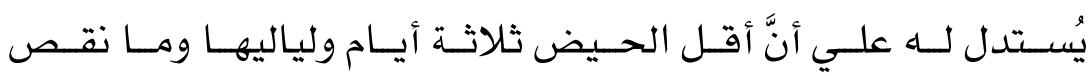

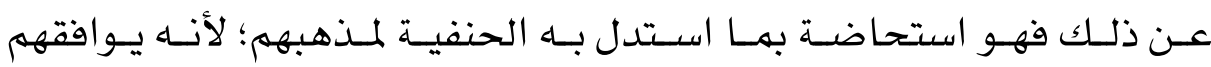

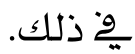
ويُسـتدل لـه بهـا دون ذلـك بهـا اسـتـدل بـه المالكيـة لمــهبهـم مـن

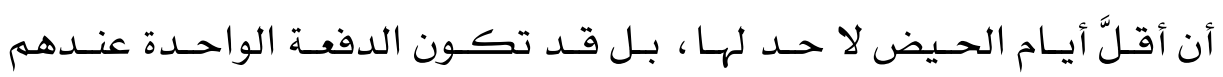

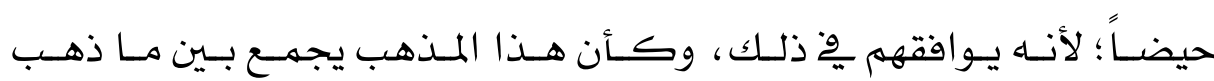

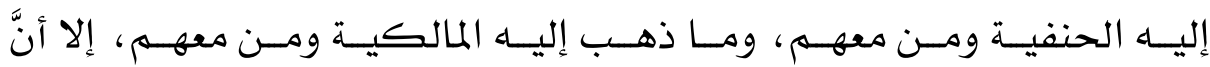

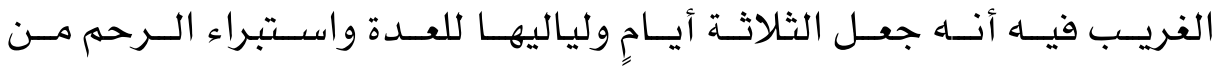
الحهـل، وجعـل مـا دون ذلــك مـن الحسيض مانعـاً مـن الصـيام غـير مسـقطٍ لوجوباه، ومانعاً للصعلاة ومسقطاً لوجوبها.

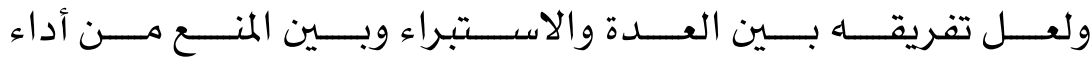

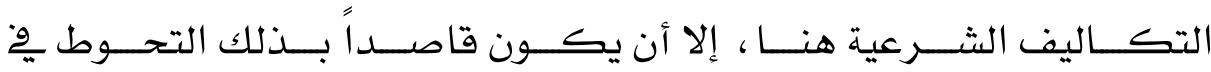
المقدرات الشرعية. 


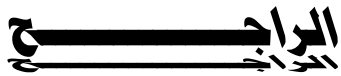

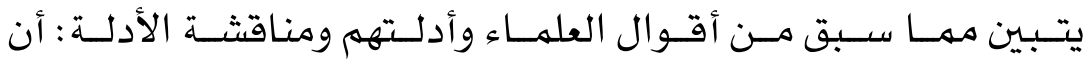

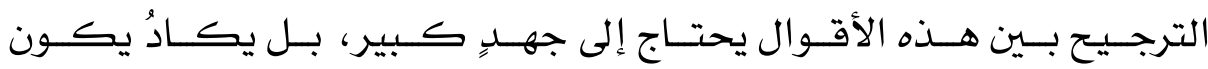

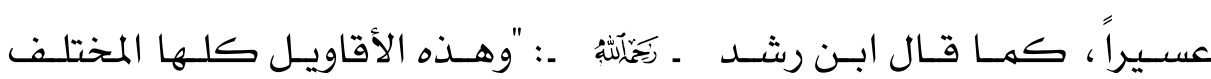

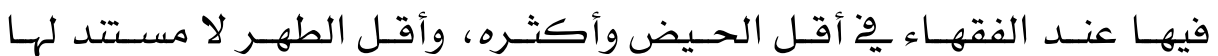

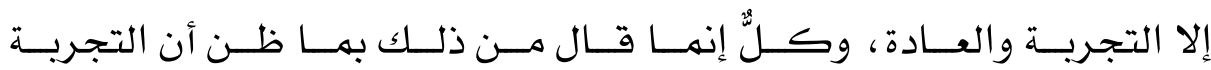

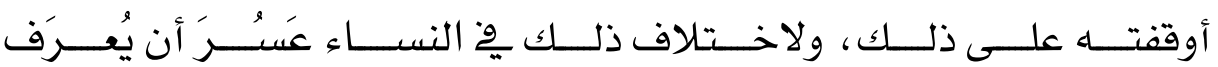

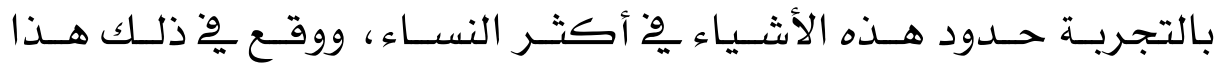
الخهلاف الذي ذذكرنا أ.هـ"('). ومــع ذلـك فـالحق : أن مـا قـال بـه المالكيـة مـن أن أقلـه لا حــد لـه هو الراجح لما يأتي: أوبًا: أن ما استدل بـا الحنفية من أحاديث فقد ضعفها الدارقطني وغيره من المحدثين. فضنلاُ عن أنَّ حديث فاطمة بنت أبي حُبيش المراد بـه الوقت لا الجهم، وأنها كانت مستحاضة فردها النبي - - إلى أيام (1) ينظر : بداية المجتهد // ب وما بعدها. 
عادتها ، و يلزم من هذا أن كل حيض لا ينقص عن ثلاثة، وقد وجد من لا تحيض ومن تحيض يوماً وليلة.

ثانباً: أن تمسك الشـافعية ومن معهم على أنَّ أقل الحيض يوم وليلة مردود" عليه كذلك بأن صفة التمييز إذا وجدت كانت دليلاً على وجود الحيض وحديث فاطهة بنت أبي حُبيش السابق ذكره فيه دلالة على أنه يعتبر التمييز بصفة الدم فإذا كان متصفاً بصفة السواد فهو حيض وإلا فهو استحاضة، وقد قال الشافعي بذلك، كها أن دم الحيض معروف لدى النساء فله رائحة كريهة تعرفها النساء، فيتحقق وجوده بها فوجب الانقياد لهذا، فإن رأته بهذه الصفة ولو ساعة أو دفعة فهو حيض، وهذا ما قال به

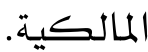

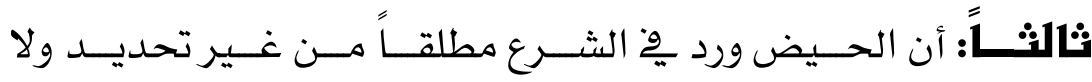

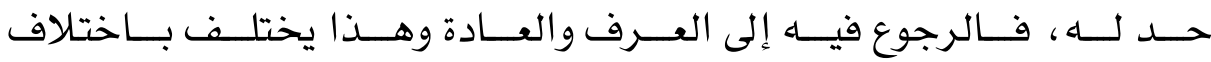
الحــرارة، والـبرودة، والتغذيسة، وصــحة كـل امــرأة وضــفها فــالرجوع

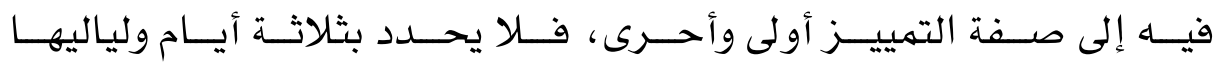
كهـا قـال الحنفيـة، ولا يتوقف علـى يـوم وليلـة كهــا قـال الشـافعية ، بـل

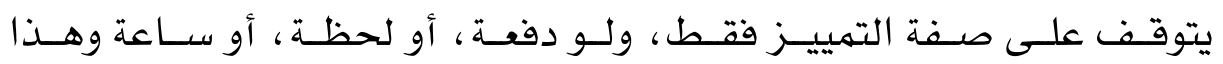

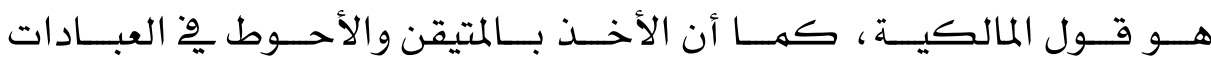
أفضل وخاصة أن الحيض يحرم به عشرة أشياء: 
المنــع مــن الصــلاة ، والصــوم، واجتـــاب دخــول المســــد ، ومـسس

المصــحف، والطــواف، وقـراءة القـرآن، وتصـيـر بــه المـرأة بالغــة، وحرمــة

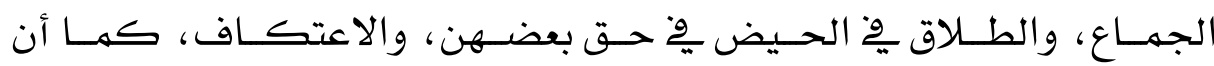
المـرأة الحــائض لا تقضـي الصــلاة وتقضــي الصــوم، وبـالطهر منـهـ يوجـب

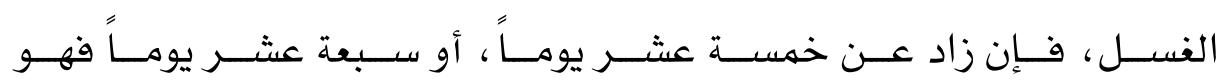
استحاضة.

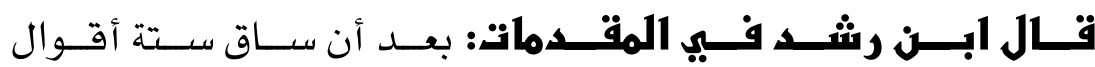

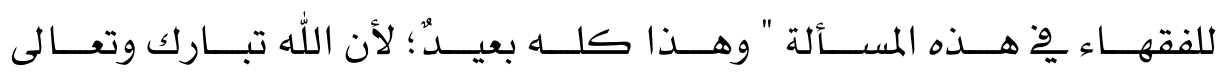
يقـول:

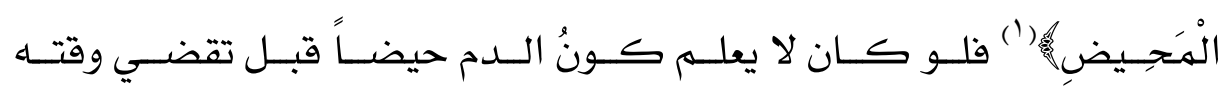
ثثلاثـة أيـام أو يـوم وليلـة لكــان الأهــر بـاعتزالهن مشـروطاً بهـا لا طريـق إلى العلى بحصوله إلا بعد تقضيـه، وذلك باطل أ.هـ"(r).

وعليــاه: فـإن مـا اســتقرت عليـهـ عـادة كـل امــرأة فهـو عادتهـا قلـة وكثترة فـلا حـد لأقلـهاه ولا لأكثتره، شـريطة أن لا يـتفير وصـفـه عمـا ثبـت التهييز بها، أو عن عادتها فتكون مستحاضة ثبت ذلك بالاستقراء (r).

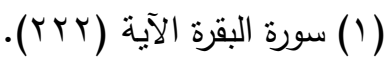

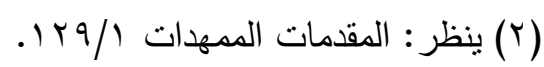
(r) يُنظر ما سبق من المراجع عند سوق أدلة المذاهب ومناقثتها. 


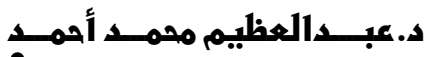

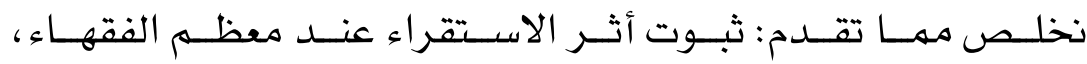

$$
\text { وإن كان وجد خلاف من البعض }
$$

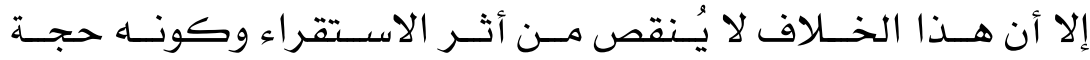

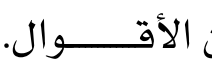

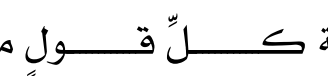

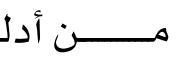

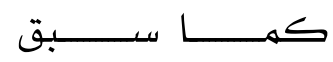

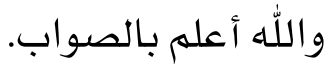

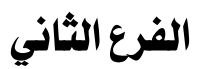

\section{أقل النفاس وأكثره}

الــدماءُ الـتي تخــرج مـن رحسم المـرأة ثثلاثـة أقسـامِ، دم حـيض:وهـو

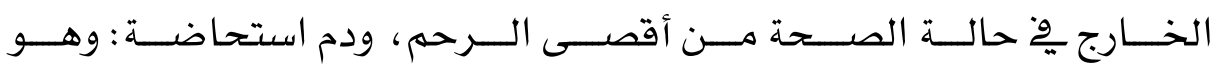

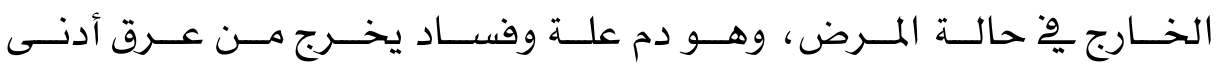

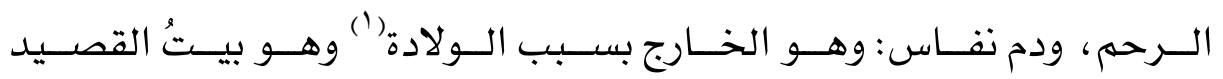

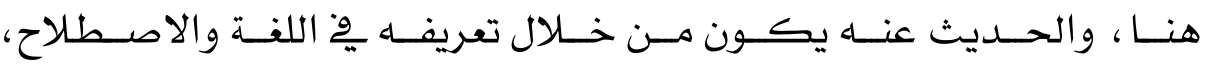




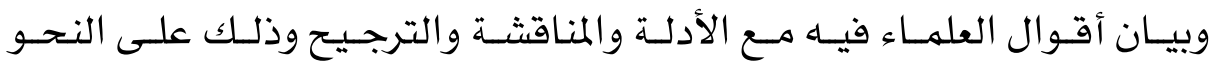

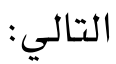

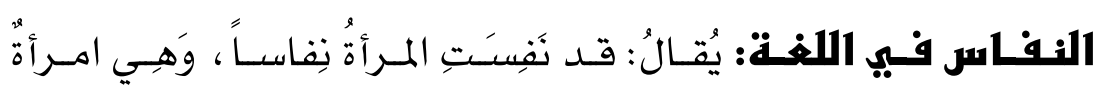

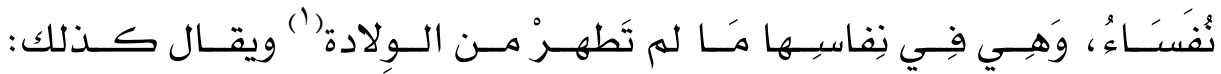

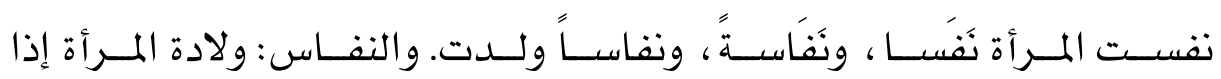
وضعت فهي تقساء، ونسوة نِقَاس (r).

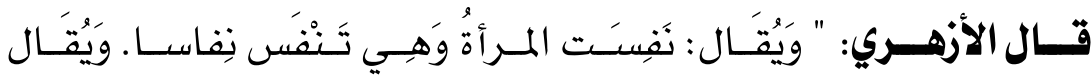

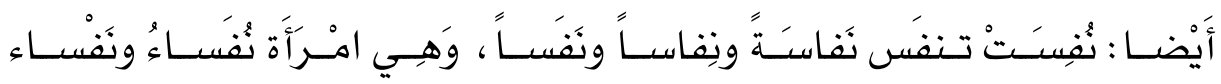

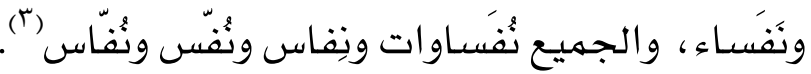

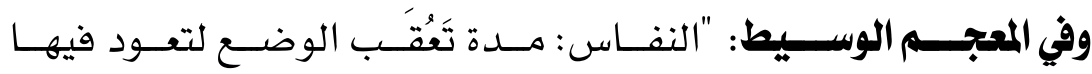

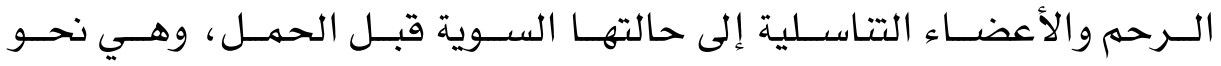

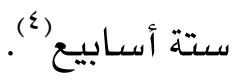

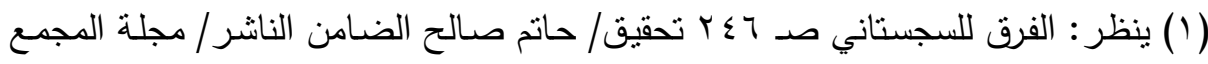

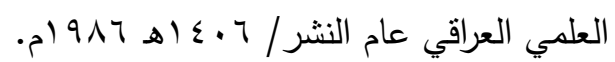

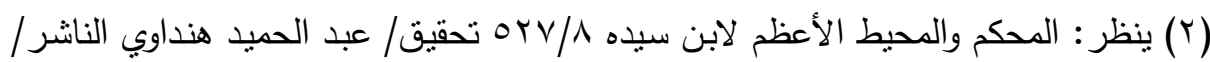

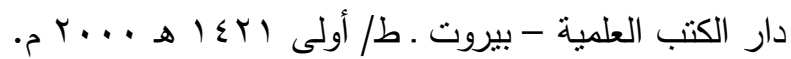

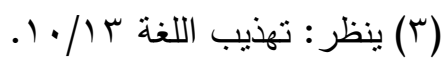

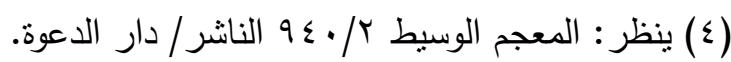


وفي الاصـــلاح: عُرِّفَ دمُ النفــاس بتعريفـات عـدةٍ تبعـاً لوجهــة

نظر كل معَرٍِّ:

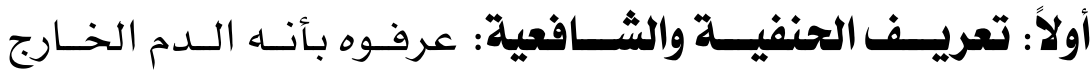

عقـب الـولادة، أمـا الخــارج مــع الولــــــــال الـولادة أو قبلـه، فهـو دم فسـاد واستحاضة.

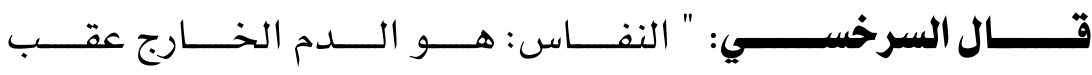

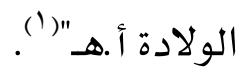

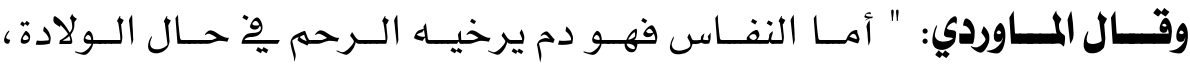

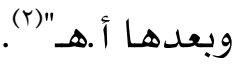

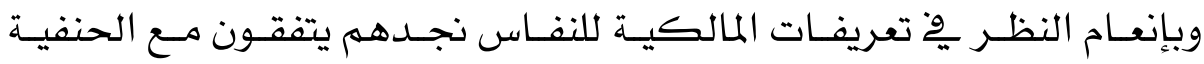
والثافعية؛ فهم يقولون بأن دم النفاس: هو ما خرج من قبّل المرأة عند ولادتها مـع الولادة، أو بعدها ولو بين توأمين. وعليه فالدم الخارج قبل الولادة عندهـم

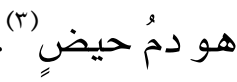

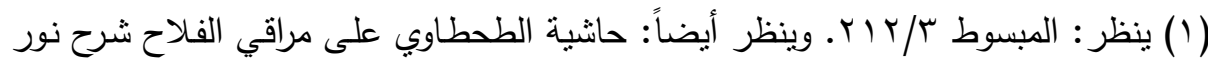

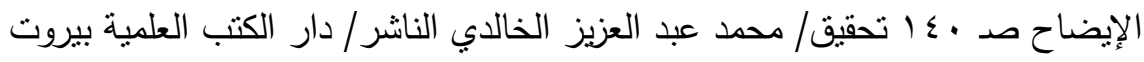

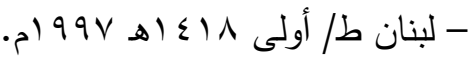

$$
\begin{aligned}
& \text { (Y) ينظر : الحاوي الكبير / / بrع. }
\end{aligned}
$$

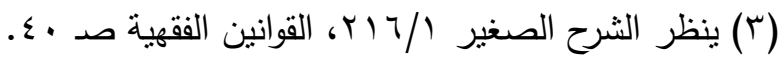


قال ابن رشــد القـرطبي: " وأمـا دم النفــاس: فهو الـدم الخـارج مـن الفــرج على العادة عند النفاس أ.هـ" (1).

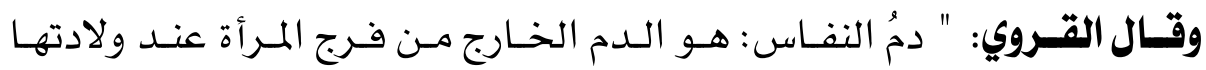
مصاحبا للولادة أو واقعا بعدها أ.هـ"(r).

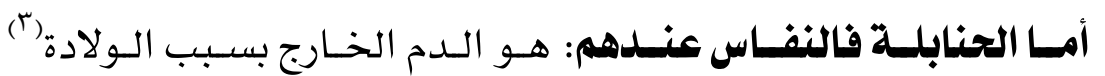

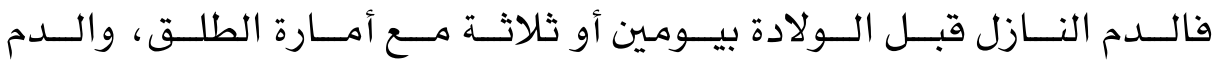
الخـارج مــع الـولادة هـو دم نفـاس عنــههم، كـالـدم الخـارج عقـب الـولادة،

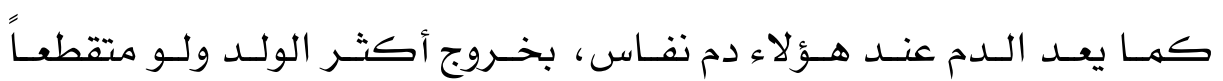

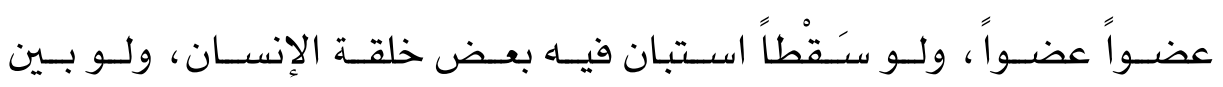

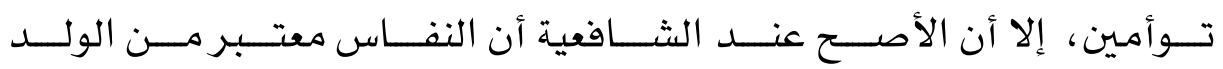

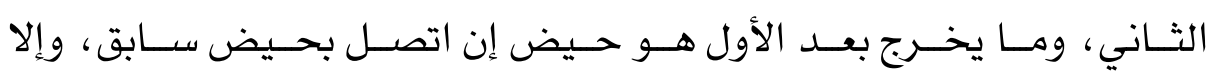
فهو استحاضة ، فإن رأت ما بعد إلقاء نطفة أو علقة فليس بنفاس (ع).

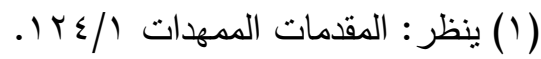
(Y) ينظر : الخلاصة الفقهية على مذهب السادة المالكية للقروي صـ ــ الناشتر : دار الكتب العلمية - بيروت ..

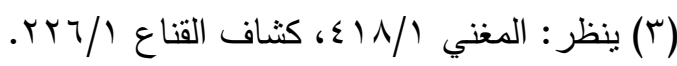

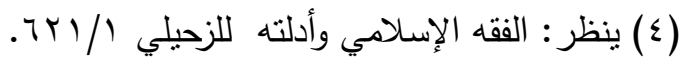


ومسن خـلال التعريفـات يتـبين لـي أن النفـاس: اسـم للـدم الخـارج مـن

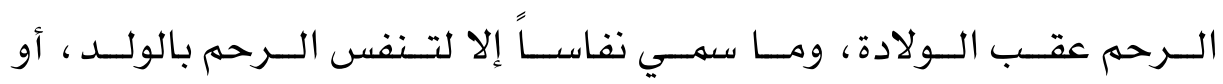

لخروج النَفْس وهو الولد أو الدم (').

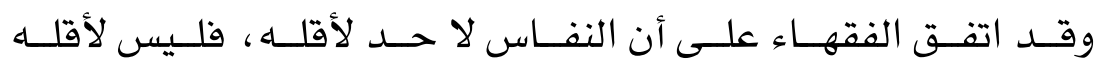

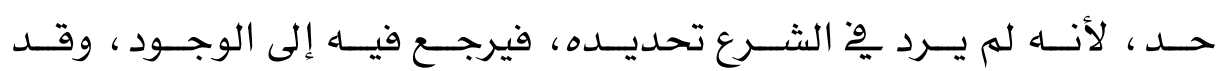

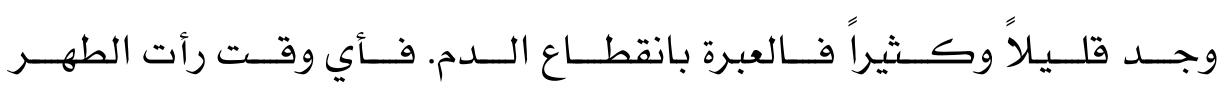

$$
\text { اغتسلت وهي طاهر (r) إن. }
$$

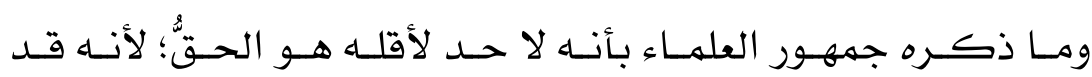

$$
\text { يكون هذا الدم مِّ لحظة أثناء الولادة، وقد تكون ولادة بـلا دم. }
$$

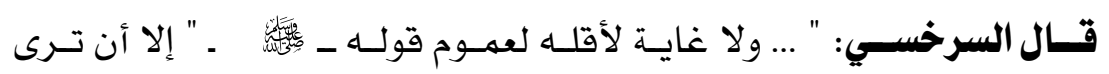

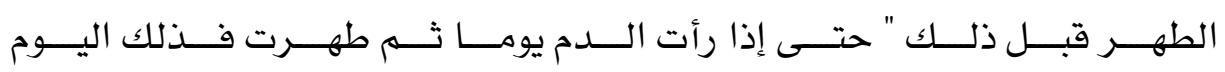

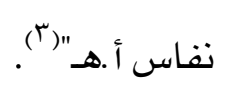

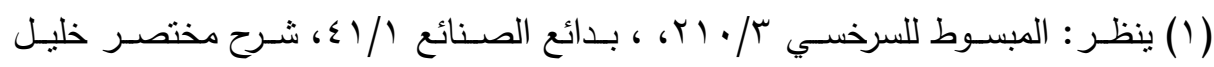

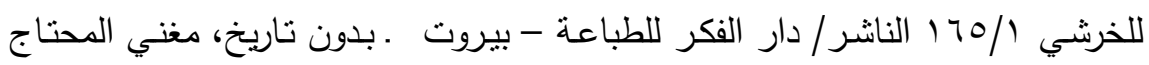

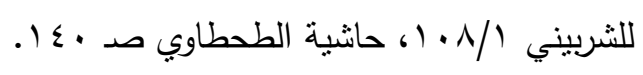

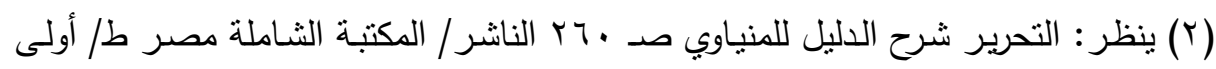

$$
\begin{aligned}
& \text { r }
\end{aligned}
$$

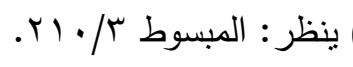




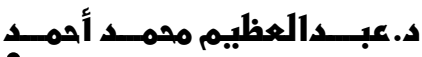

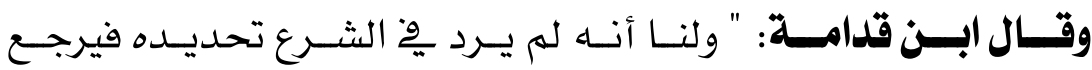

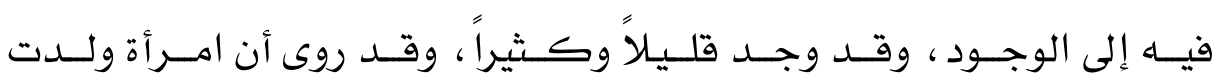

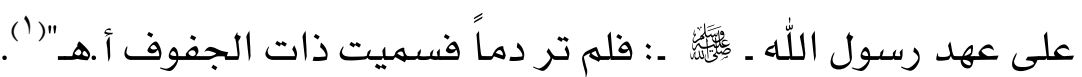
وأما أكثره فقد اختلف الفقهاءُ فيه إلى قولين:

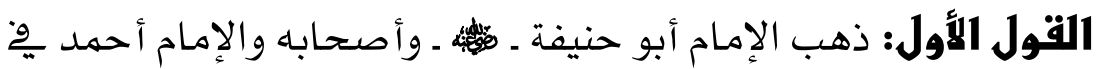
إحدى الروايتين عنها: إلى أنَّ أكثره أربعون يوماً، وما زاد عن ذلك فهو استحاضة، وهو قول عمر بن الخطاب، وابن عباس، وعثمان بن أبي العاص، وعائذ بن عمرو، وأنس، وأم سلمة - (r) القول النثانبي: أن أكثره ستون يوماً وهو قول الإمام مالك، وباه قال الإمام الشافعي، والإمام أحمد بِّ الرواية الثانية، وهو قول عطاء بن أبي

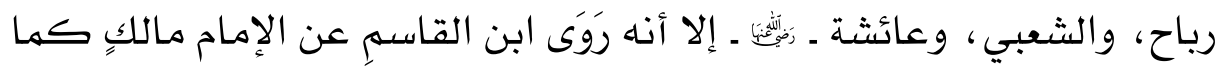
ذكر ابن رشد وغيره: أنه رجع عن قوله ستين وقال: يسأل عن ذلك النساء،

وأما أصحابه فتابتون على القول الأول (1).

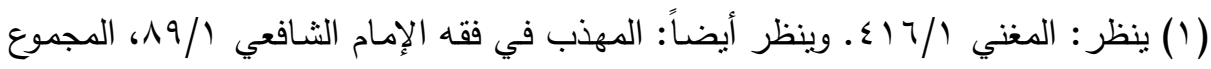

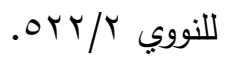

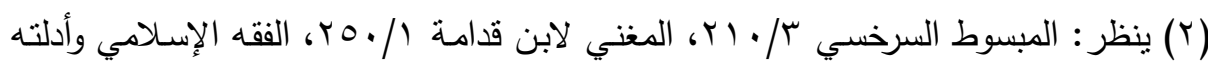

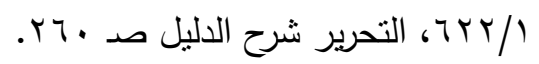

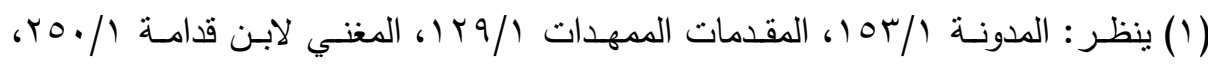

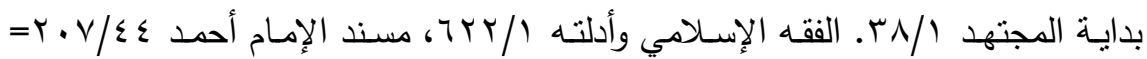


أولاً: أدلة أصهاب القول الأول: استدل أصحاب القول الأول القائلون

بأن أكثره أربعون يوماً بأدلة منها :

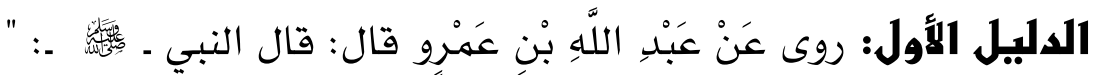

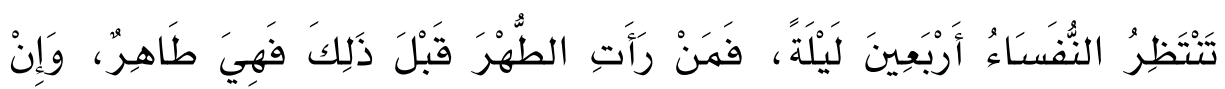

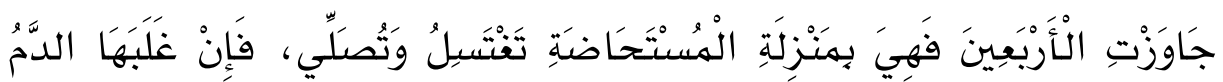

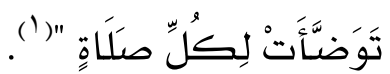
وجه الدلالة من المديث: إنَّ هذا الحديث وغيره مها ذكر ِِّ الباب والذي لم أذكره خشية الإطالة أدلة واضحة الدلالة على أن أكثر النفاس أريعون يوماً ، فهي متعاضدة صالحة لللاستدلال بها ، فالمصير إليها متعين. الدليل الثانيب: إجماع الصحابة: قال الترمذي بعد أن ذكر حديث

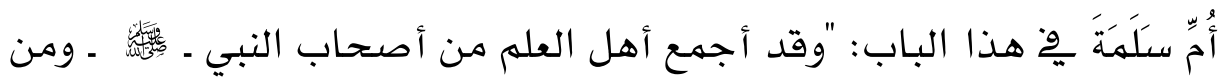

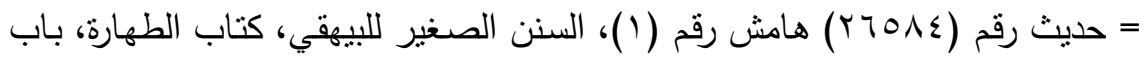

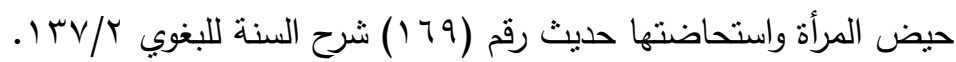

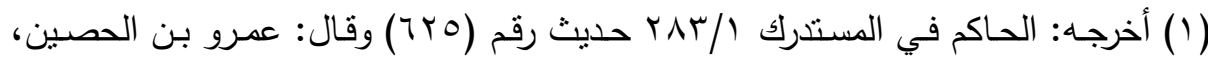

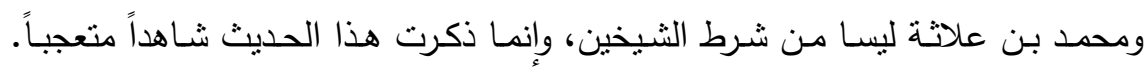

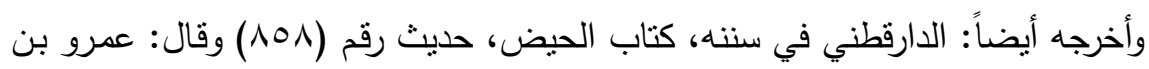
الحصين ، وابن علاثة ضعيفان متروكان. 
بعدهم على أن النفساء تدع الصلاة أربعين يوماً إلا أن ترى الطهر قبل ذلك

فإنها تفتسل وتصلي، ولهم يعرف لهم مخالف يخ عصرهم فهذا إجماع أ.هـ"( ').

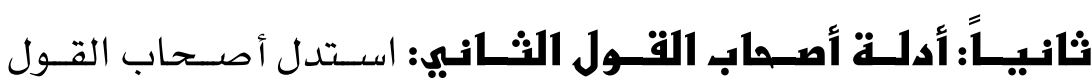

الثاني القائلون بأن أكثر مدة النفاس ستون يوماً بأدلة منها :

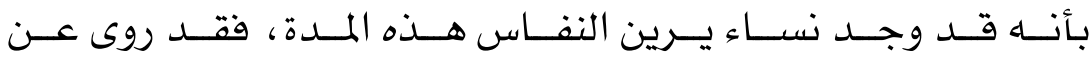
الأوزاعـي قـال: عنــنـا امـرأة تـرى النفــاس شــهرين فـتعـين المصــير إليــه،

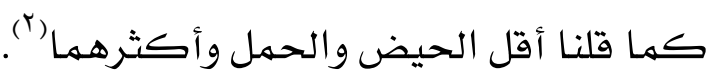

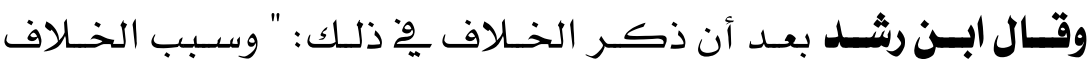

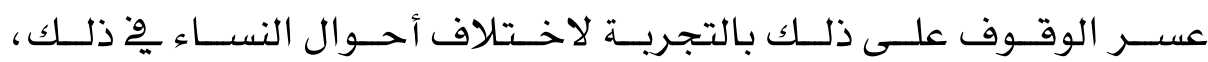

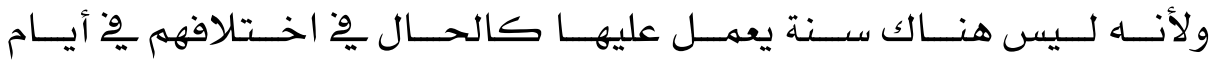

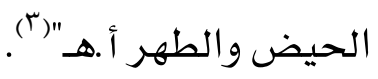

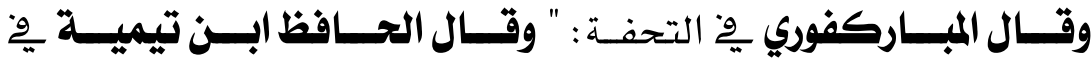

المنتقــى معنـى الحسـديث كـانـت تـؤمر أن تجلس إلى الأربعـين لـــلا يكــون

(1) ينظر : سنن الترمذي، أبواب الطهارة، بـاب مـا جاء في كم تمكث النفساء حديث رقم

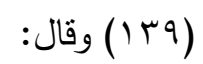

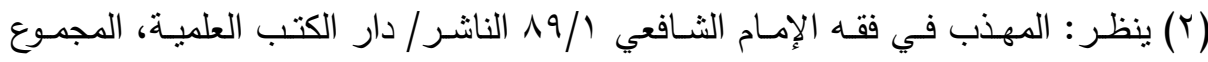

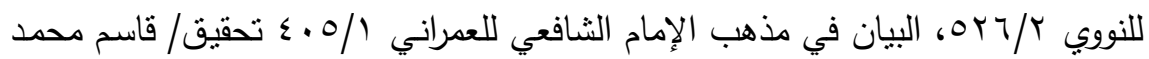

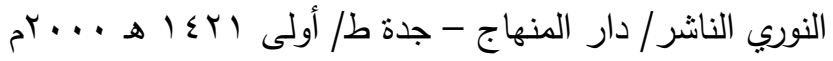

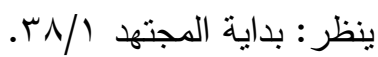




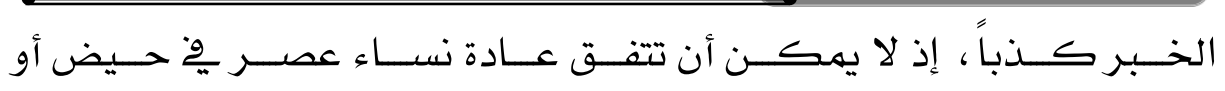

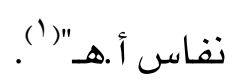

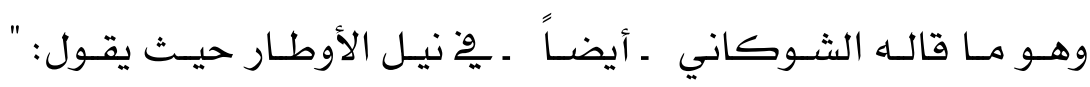

قلـت ومعنـى الحسـديث كانـت تـؤمر أن تجلـس إلى الأربعـين لـئلا يكــون

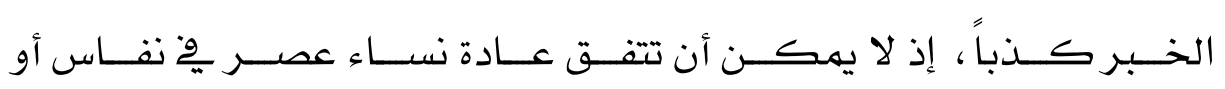

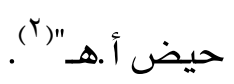

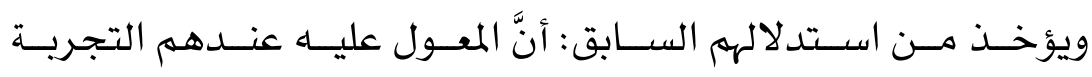

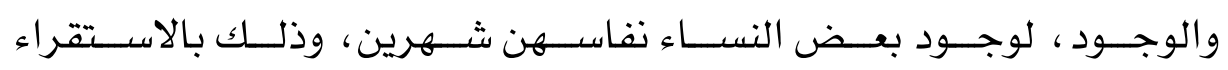
الدال عليه وجود نساء يرين الدم هذه المدة.

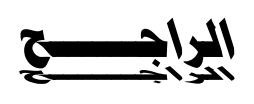

وبعـد عـرض مـا ذكـر مــن أقـوال الفقهـاء وأدلـتهم يتـبـين لـي أن

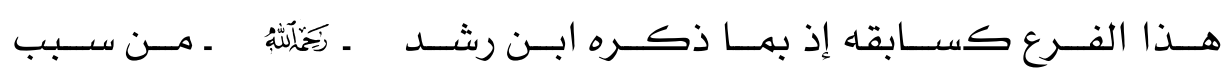

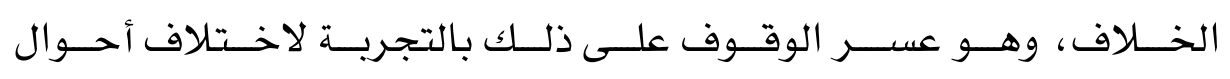

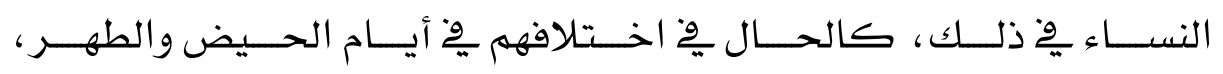

(1) ينظر : تحفة الأحوذي // / آب أبواب الطهارة، باب ما جاء في كم تمكث النفساء حديث

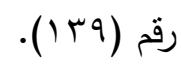

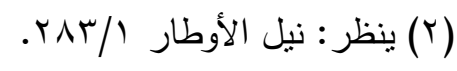


وأيضـاً مـا ذكــره ابـن تيهيـة والشـوكاني: بأنسه لا يهكـن أن تتقـق عـادة

نساء عصر مِّن نقاس أو حيض ')

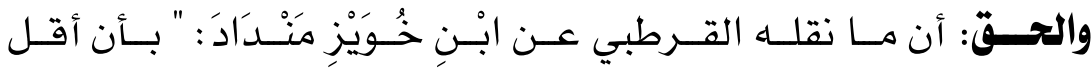

الحــيض والنفــاس وأكثـره، وأقـل الحهـل وأكثــره مــأخوذ مــن طريـق

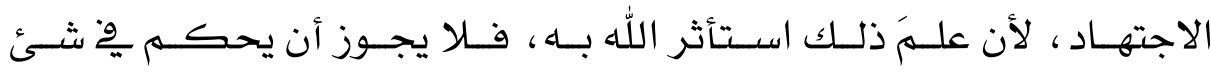

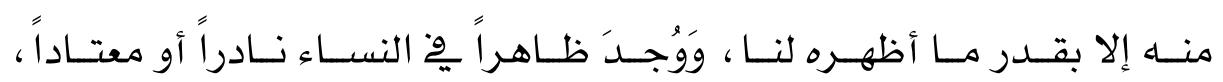
ولمـا وجـدنا امـرأة قـد حملـت أربـع سـنـين وخهـس سـنـين حكهنـا بـذلك،

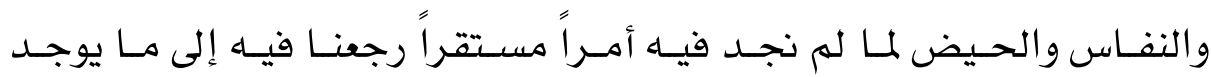

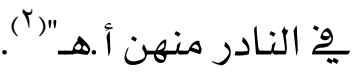

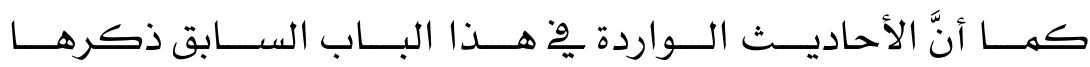

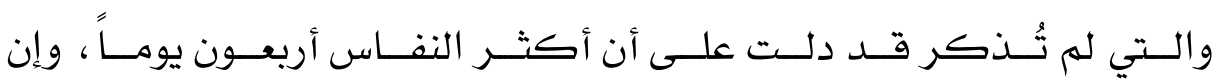

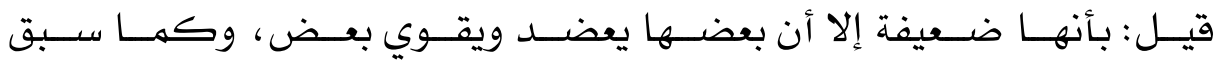

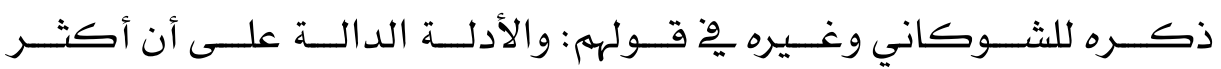
النفــاس أربعــون يومهــاً متعاضــــدة بالغـــة إلى حـــد الصـــلاحية والاعتبـــار

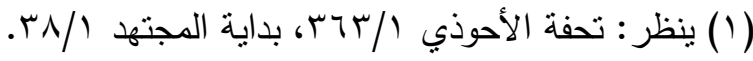

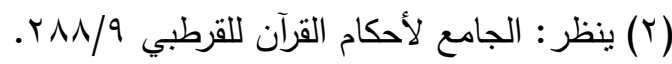




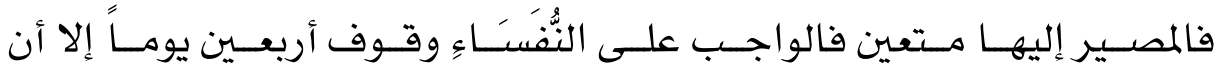

ترى الطهر قبل ذلك فإنها تغتسل وتصلي (')

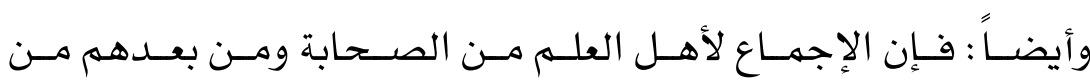

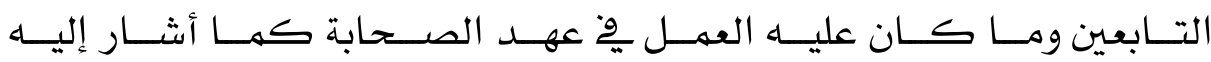

الترهـذي السـابق ذكــره يـرجحح مـا قالـه أصـــاب القـول الأول، كهــا أن هـذه الأحاديـث مـرويسة عـن عمـر وابنـه وعائثـة وابـن عبـاس وأبـي هـريـرة

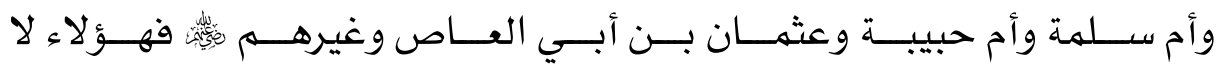

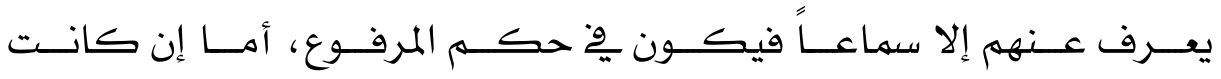

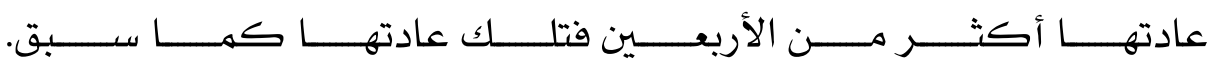
والله أعلى بالصواب.

نخلــص مهــا تقــدم: ثبـوت أثــر الاســتقراء عنـــد معظــم الفقهـاء،

وإن ككـان وجــد خـلاف مـن الـبعض إلا أن هـذا الخـلاف لا يُنقص مسن أثـر

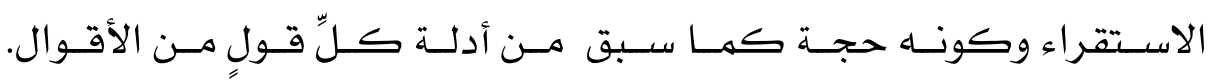
والله أعلى بالصواب. 


\section{الفرع الثالث}

\section{حكم صلاة الوتر (1)}

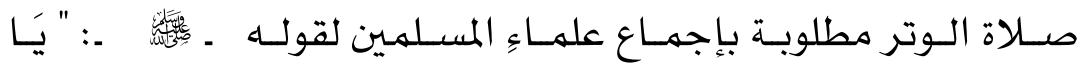

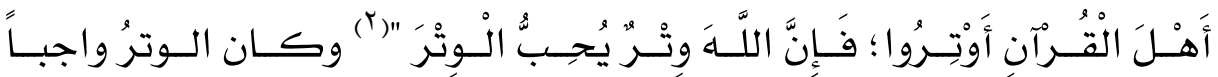

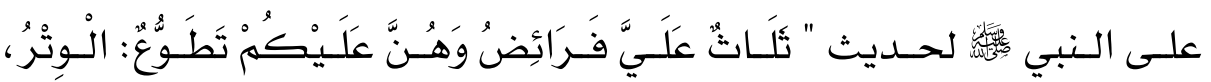

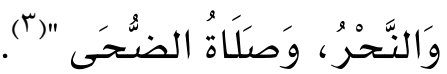

(1) الوتر : الوتر (بفتح الواو وكسرها) لغـة: العدد الفردي، كالواحد والثلاتثة والخمسة، ومنـه

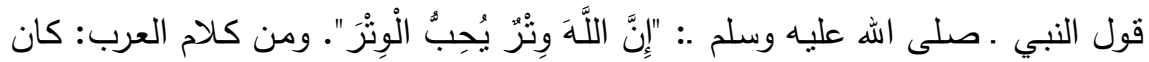
القوم شفعاً فوترتهم وأوترتهم، أي جعلت شفعهم وتراً. وفي الحديث:".....وَمَنِ اسْتَجْمَرَ

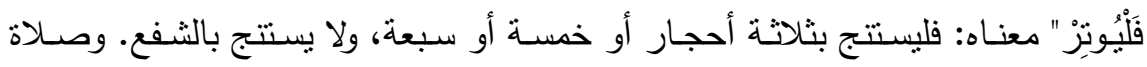
الوتز في الاصطلاح: هي صـلاة تفعل ما بين صسلاة العشاء وطلوع الفجر، تختم بها صلاة الليل، وسميث بذلك لأنها تصلى وثراً، ركعة واحدة، أو ثثلاثا، أو أكثر ، ولا يجوز جعها شفعا، ويقال: صليت الوتر ، وأوترت، بمعنى واحد. ( ينظر : الموسوعة الفقهية

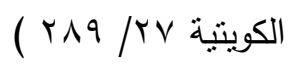

(Y) أخرجه: أبو داود في سننه، كتاب الطهارة، باب استحباب الوتر حديث رقم (T ا ع ( ) وابن ماجـه في سـننه، كتاب إقامـة الصـلاة والسنة فيها، بـاب مـا جـاء في الوتر حديث رقم

(9 1 (1) ) وابن خزيمة في صحيحه، كتاب الصلاة، باب ذكر الأخبار المنصوصـة .....

$$
\text { حديث رقم (V T • 1 ) قال الألباني: صحيح. }
$$

(r) الحديث رواه: الأصبهاني في حلية الأولياء وطبقات الأصفياء 9/ وبr، والزبلعي في

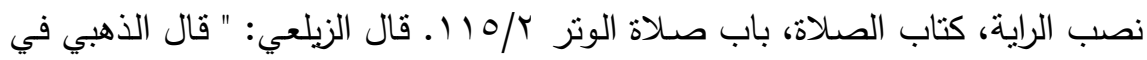
مختصـره: سكت الحساكم عنه، وهو غريب منكر ، وأبو جنـاب الكلبي ضـفه النسـائي. 


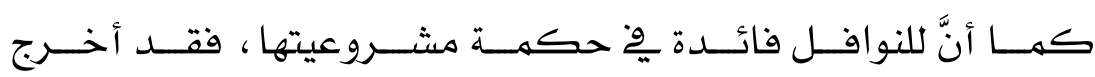

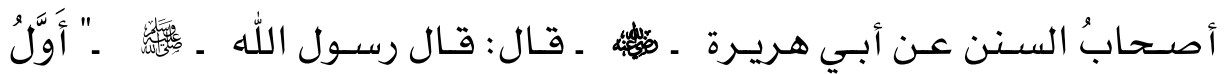

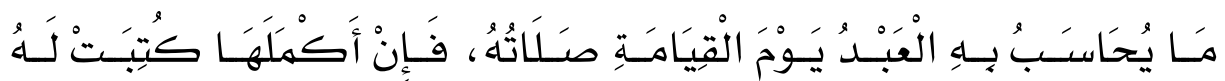

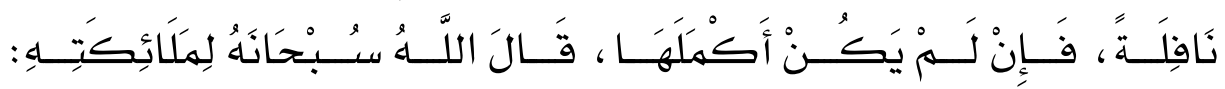

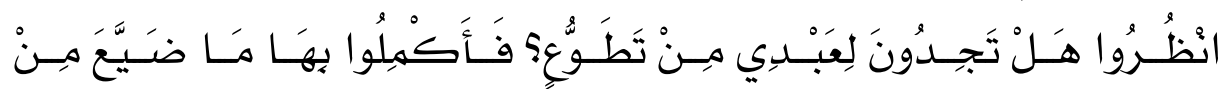

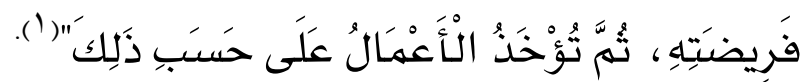

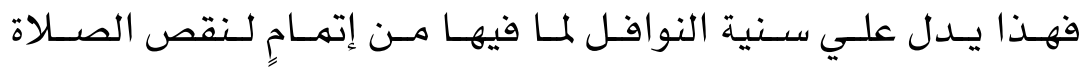

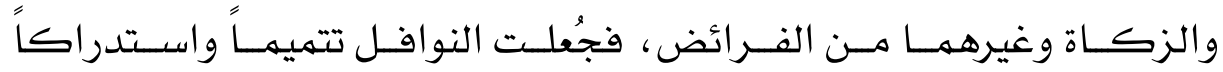

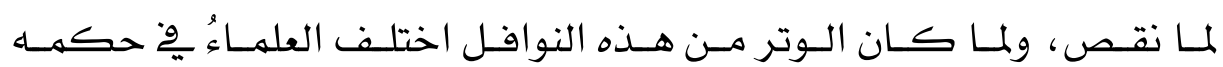

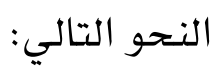

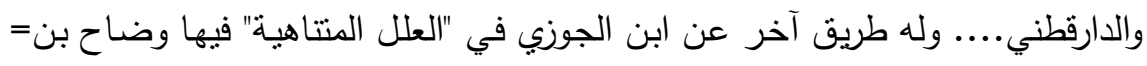
$=$

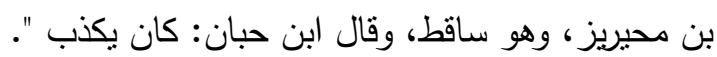

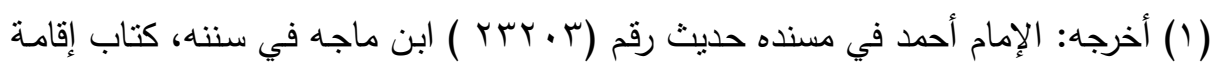

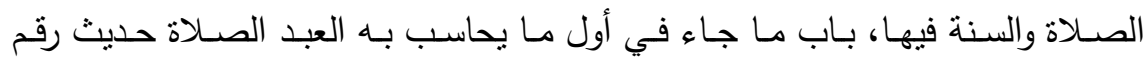

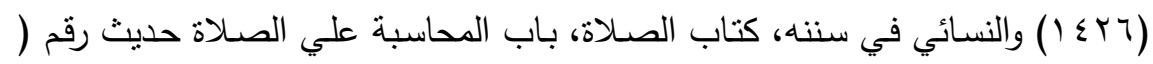

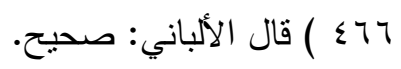




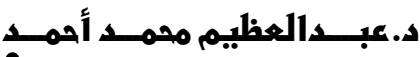

تنقيع الإراء في حيويت الإستقراء سلان

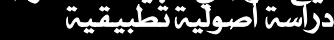

القول الأول: ذهب المالكية والشافعية والحنابلة إلي القول: بأن

الوتر سنة مؤكدة، وهو قول أبو يوسف ومحمد من أصحاب أبي حنيفة ').

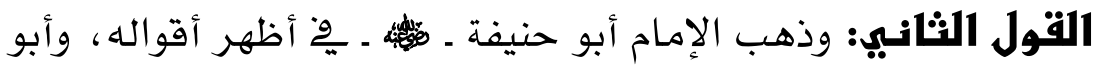

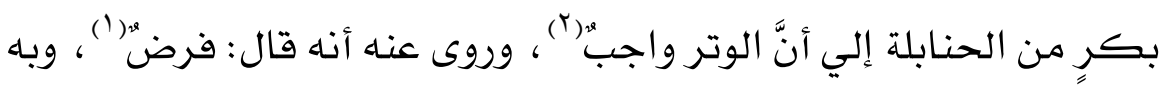

(1) ينظر : التلقين في الفقه المـالكي للقاضي عبدالوهاب / بـس، المقدمات الممهدات لابن

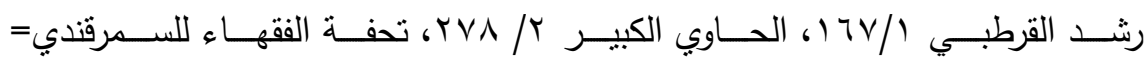

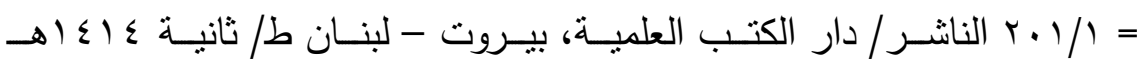

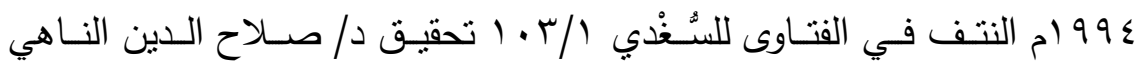

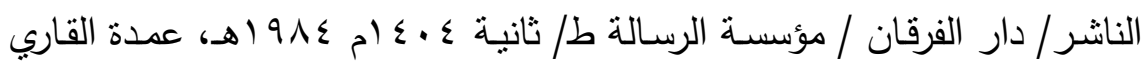

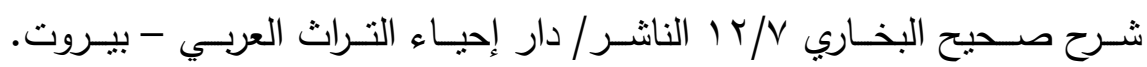

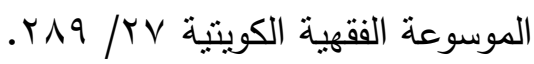

(Y) قال بدر الدين العيني: " وأبو حنيفـة لم ينفرد بذللك، هذا القاضـي أبو بكر بن العبي ذكر عن سحنون وأصبغ بن الفرج وجوبه، وحكى ابن حزم أن مالكاً قال: من نزكـه أدب، وكانت جرحهه في شهادته، وحكاه ابن قدامـة في (المغنـي) عن أحمد، وفي (المصنف) عن مجاهد بسند صحيح: هو واجب ولم يكتب، وعن ابن

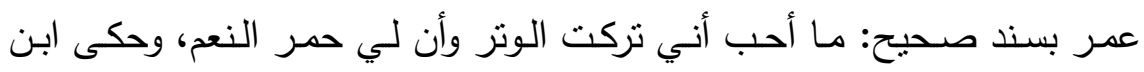

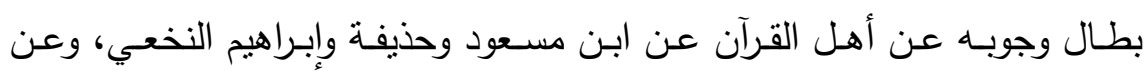
يوسف بن خالد السمتي شيخ الثـافعي وجوبه، وحكاه ابن أبي شيبة أيضـا عن 
أخذ زفر ، وروى عنه أنه قال: سنة وبه أخذ أبو يوسف و محمد (r).

قـال عــلاء الـدين الســــرقندي: ".... اختلفــت الروايـات فيـهـ عـن

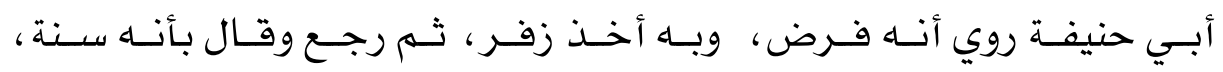

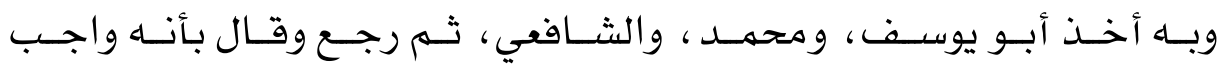

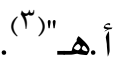

سعيد بن المسيب وأبي عبيدة بن عبد الله بن مسعود والضحاك أ.هـ" ( ينظر :

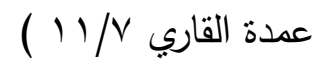

(1) ومراده بأنه فرضٌ: أنه فرضٌ عملي، وهو الواجب، لا اعتقادي.

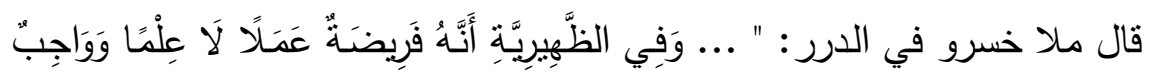

$$
\text { عِلْمًا" }
$$

= ( ينظـر : درر الحكـام شـرح غـرر الأحكـام / / I/ وينظـر أيضـاً: الموسـوعة

$$
\text { (Yq)/rV الفقهية الكويتية }
$$

وَوقالَ النَّجم النَّنَفِيّ في منظومته:

$$
\text { وَالْوتر فرض وبدا بِذكرِه ... فَي فجره فَسَاد فرض فجره }
$$

( بنظر : عمدة القاري Y/V)

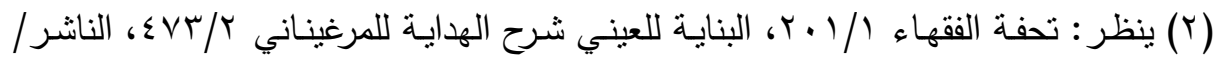

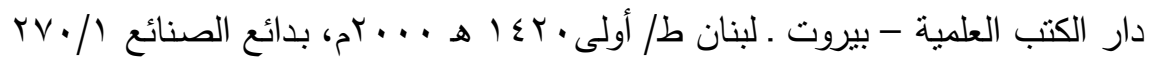

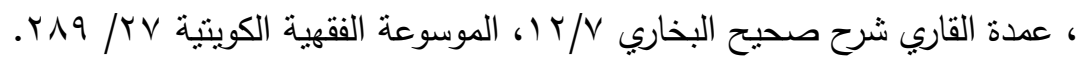

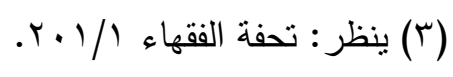


وقـال صـاهبْ البـنابـة: " لمـا فــرغ مـن بيـان الفـرائض ومتعلقاتهـا

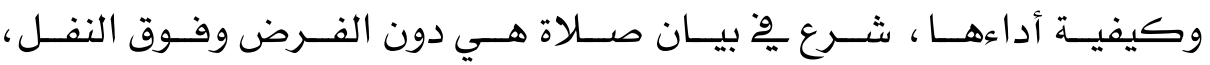
وهـي صــلاة الـوتر ، وقدمــه علـى النوافـل؛ لأن الواجسب فوقهـا ، وهـــو دون الفــرض، فــذكره بينههـــا؛ لأن حقـــه أن يكـــون بــين الفــرض والنفــل أ.هـ" ('). وقال ابن المنذر: " .... و له يذهب إلى هذا غير أبي حنيفة" (').

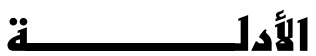

أولاً: أدلة الجمهور القائلين بأن الوتر سنة مؤكدة، استدلوا بعدة

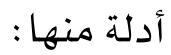

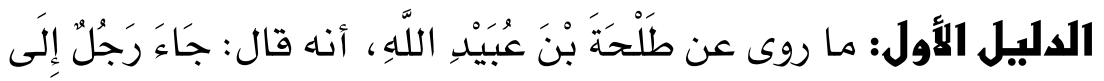

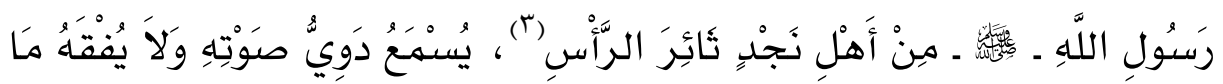

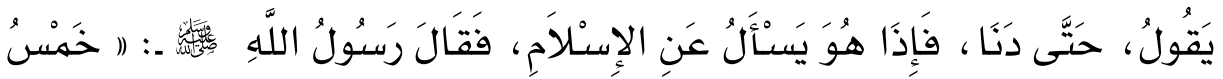

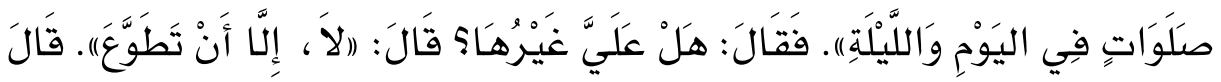
رَسبولُ اللَّهِ

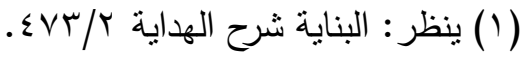

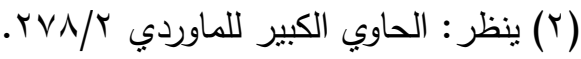

$$
\begin{aligned}
& \text { (Y) ثائر الرأس: شعره متفرق. }
\end{aligned}
$$


تَطَوَََعَ). قَالَ: وَذَكَرَ لَهُ رَسَولُ اللَّهِ

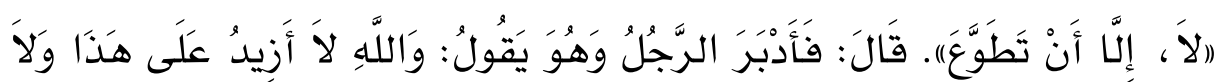

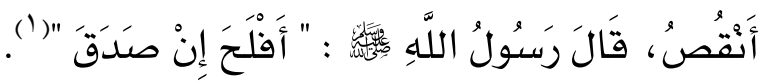

\section{وجه الدلالة من الهديث:}

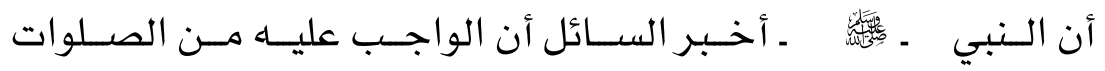
إنهــا هـــو الخهـس، وقـد تـبين مطابقـة الجـواب للسـؤال، فـلا يجـب شـئ

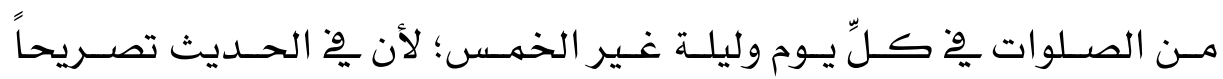

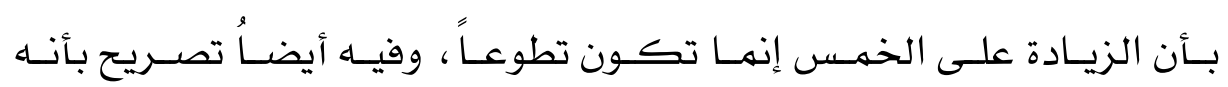

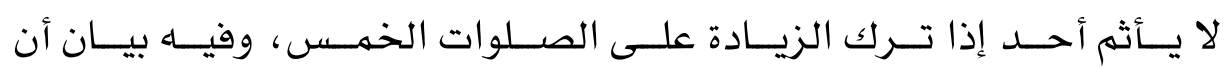

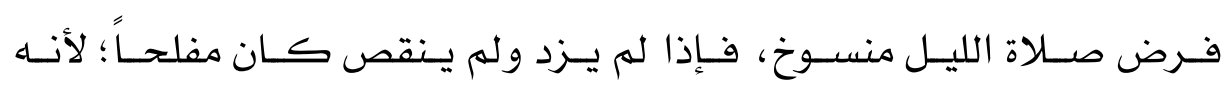

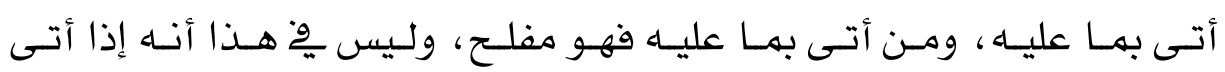

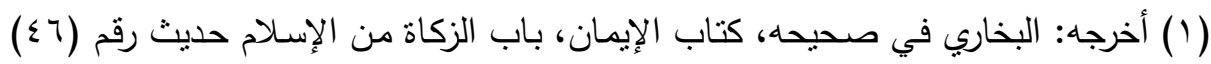

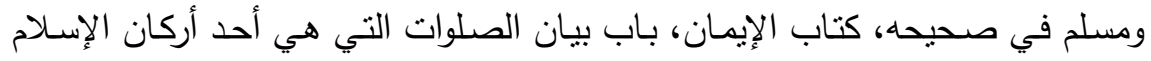

حديث رقم (1) (1). (1) (1) 


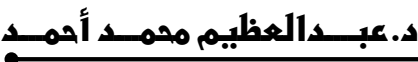

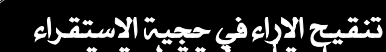

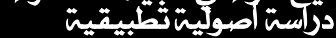

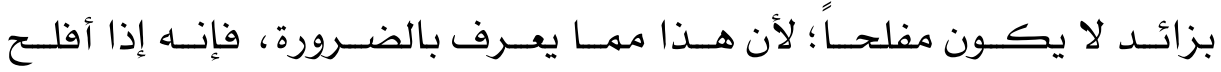

بالواجب فلأن يفلح بالواجب والمندوب أولى (1).

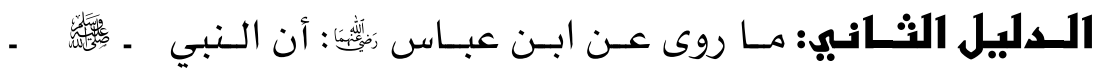

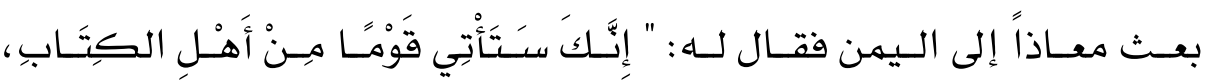

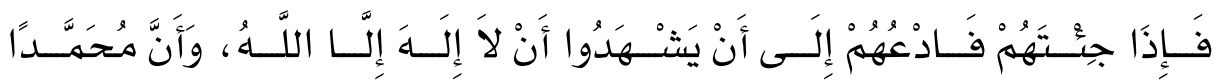

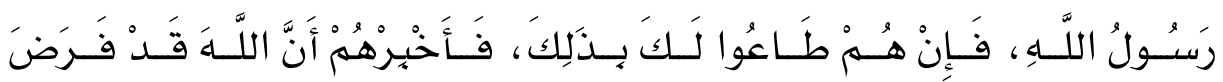

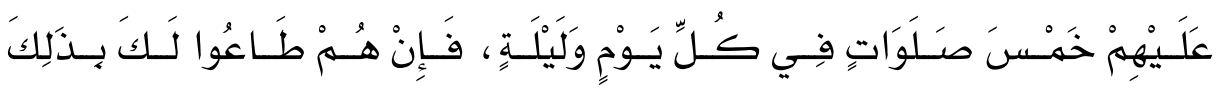

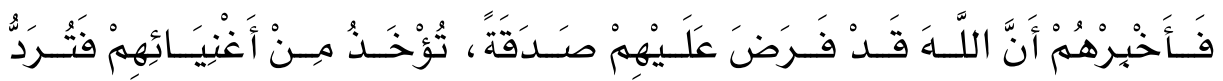

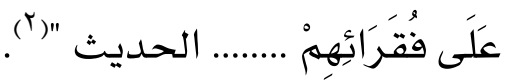
وجه الدلالة من الهدبث:

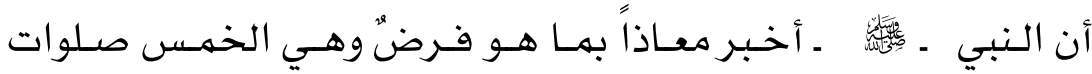

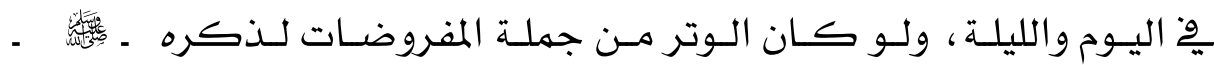

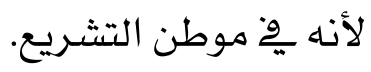

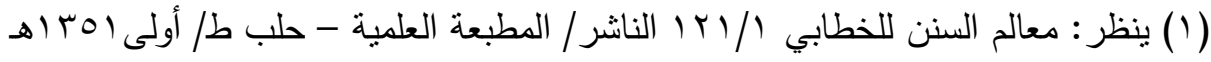
rسو ام، وينظر أيضـاً: تعليق وشرح الثيخ/ محمد فؤاد عبد الباقي علي الحديث في

$$
\text { صحيح مسلم حديث رقم (1) (1). }
$$

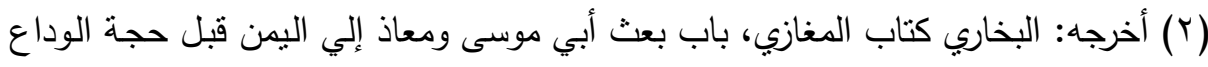

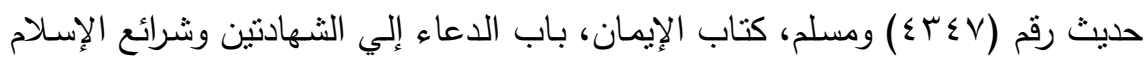

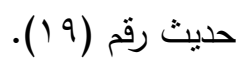

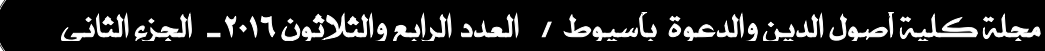




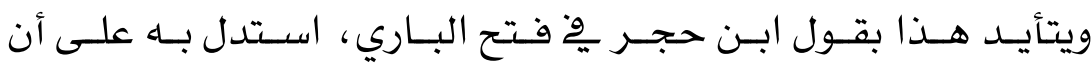

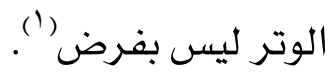

قـال النـووي بعـد ذكــره لهـذا الحســيث: "وهـــا مـن أحسـن الأدلـة؛

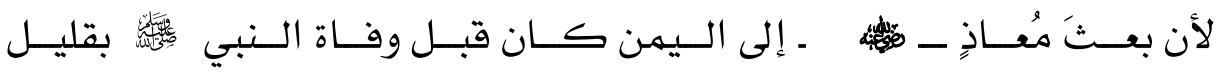

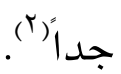

وعلى هــذا فـالوتر لـيس بواجـبِ بنـاءً علـي هـــا الــليل وغـيره مـن

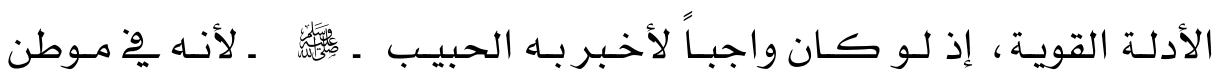

$$
\text { البيان كما قلت. }
$$

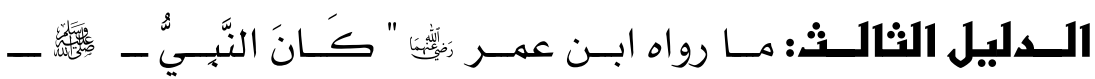

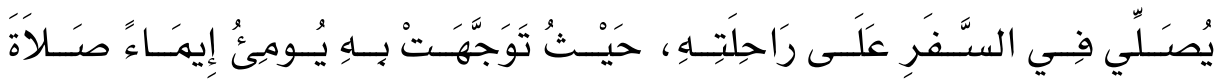

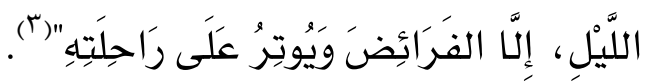

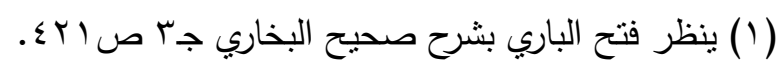

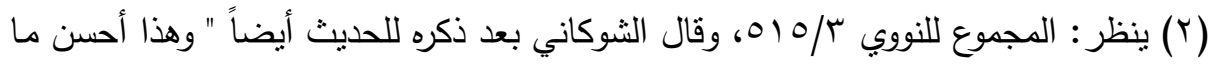

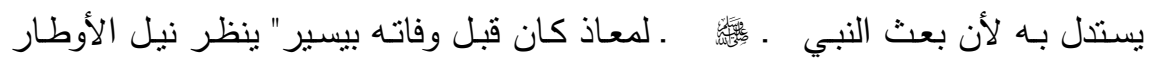

$$
.1 \% \mathrm{~N} / \mathrm{r}
$$

ولعل المراد بقولهم " كان قبل وفاته بيسير " أبي أنه لم يرد نسخ له.

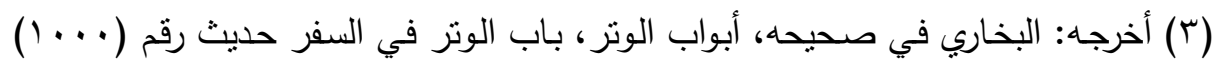

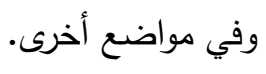

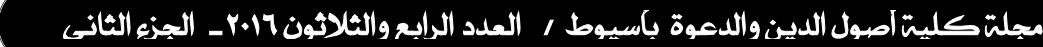




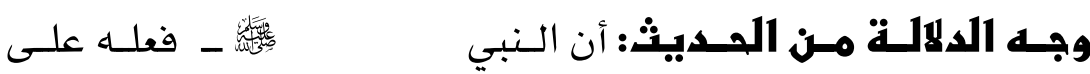

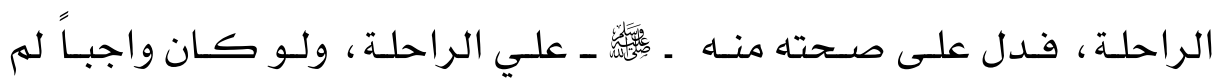

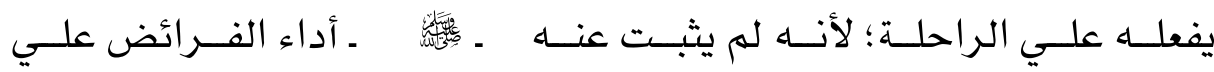
الراحلة.

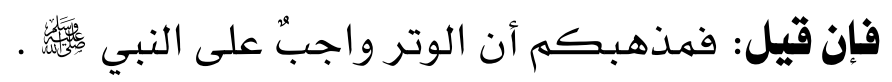

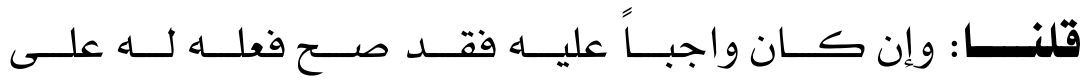

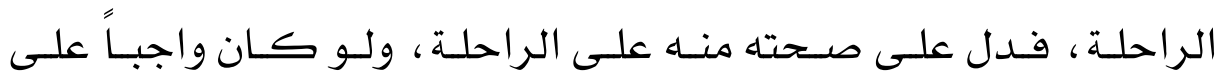
العهوم للم يصح على الراحلة كالظهر. فإن قيل: الظهر فرضٌ والوتر واجبٌ وبينهما فرق.

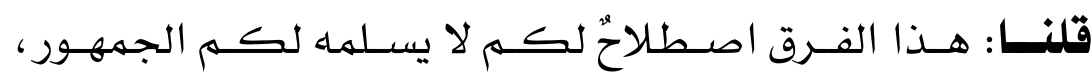

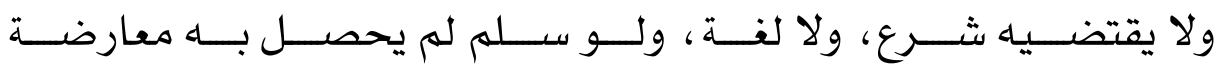

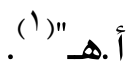

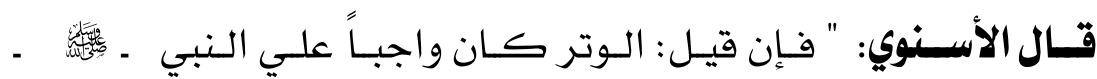

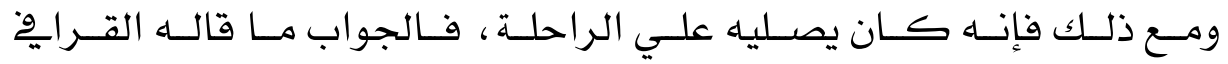

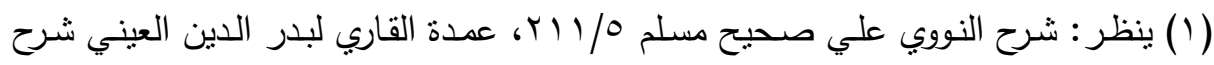

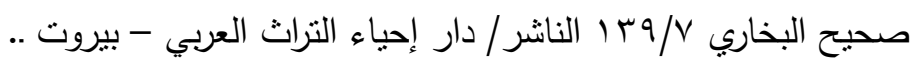




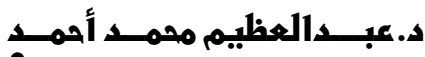

تثقيع الاراء في حجيت الاستقراء سلا

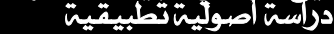

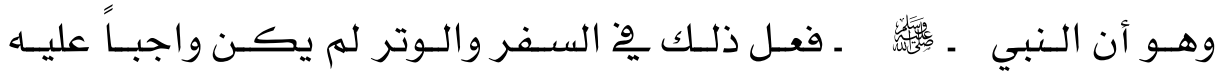

$$
\text { إلا عِّ الحضر أ.هـ "( (1). }
$$

قــال ابــن حجـــر العســقلاني: " واسـتدل بـهـ علـى أن الـوتر لـيس

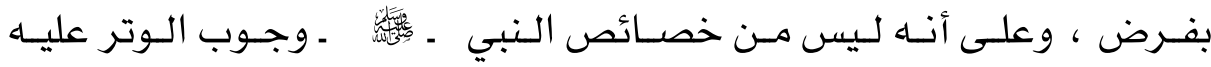

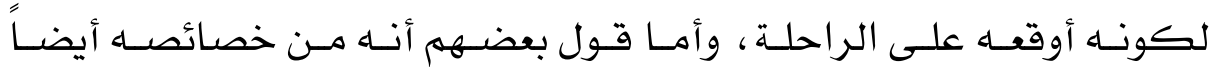
أنـه يوقعـه على الراحلـة مـع كونـهـ واجبـاً عليـه فهـي دعـوى لا دليـل عليهـا؛

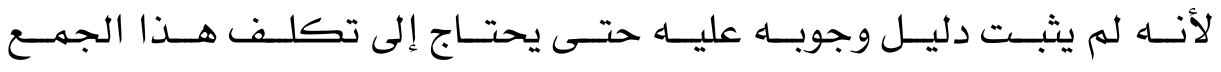

$$
\text { واستدل به على أن الفريضة لا تصلى على الراحلة أ.هـ"(؟). }
$$

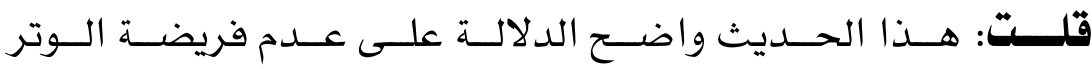

ووجوبـهـ إذا المكتوبــة متفـق عليهـا بأنهـا لا تــؤدى علـى الراحلــة، والـوتر يجوز فعله على الراحلة من غير ضرورة مما يدل على تشبيهه بالسنن الــليل الزـــامسر: الاســتقراء: اسـتدل الجههـور علـي مــا قـال

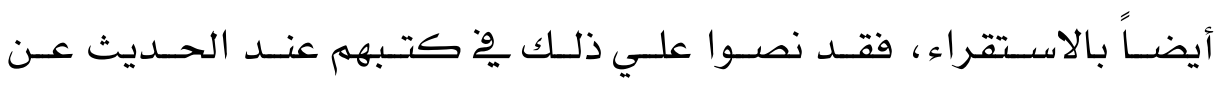
الوتر، ومن هذه النصوص: - مل

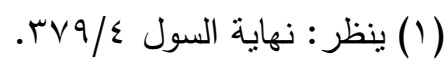

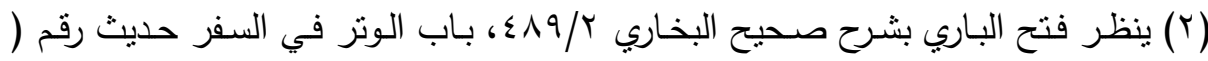

$$
\text { ( } 1 \ldots
$$

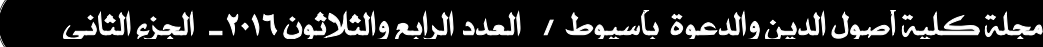


قـال الإمسام الفزالـي بعـد تعريفـه للاسـتقراء: " كقولنـا يوْ الـوتر :

لـيس بفـرض، لأنـه يـؤدى على الراحلـة ، والفـرض لا يـؤدى علـى الراحلـة ،

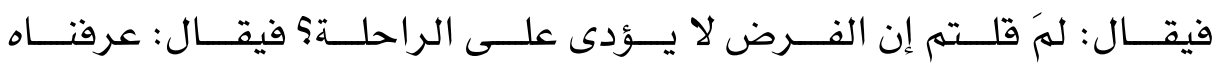

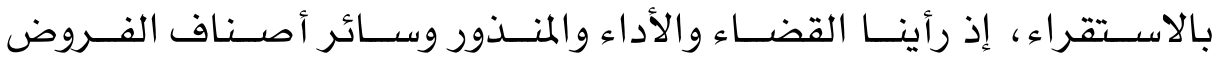
لا تــؤدى علـى الراحلــة، فقلنــا : إن كــل فـرض لا يـؤدى علـى الراحلــة

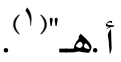

وقـال النــووي في المجمــوع: " واسـتـدل الثـافعي والأصـحاب على أن

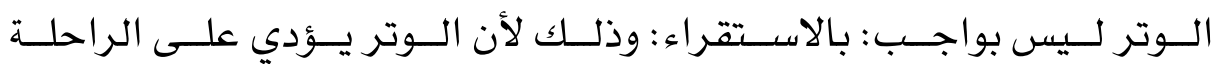

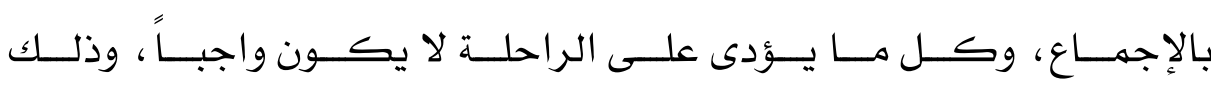

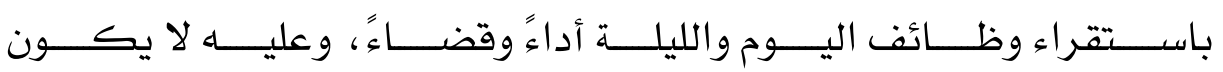

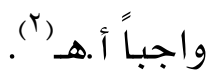

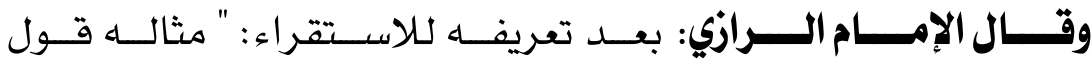

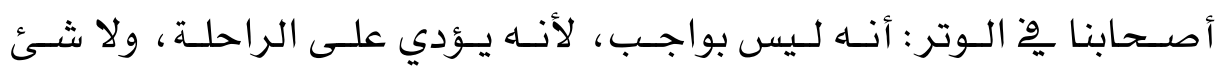
من الواجب يؤدى على الراحلة.

(1) ينظر : المستصفى للإمام الغزالي

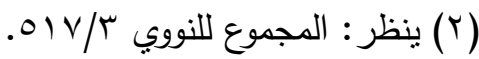




\section{د. عبــــالعظليم محمسـ أحمـــ}

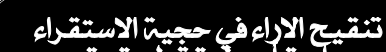

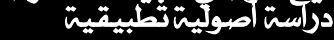

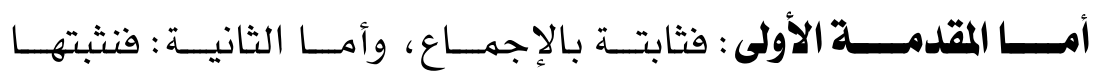

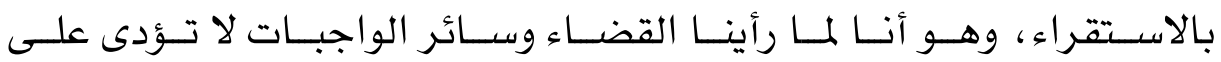
الراحلة : حكمنا على كل واجب بأنه لا يؤدى على الراحلة أ.هـ. (1).

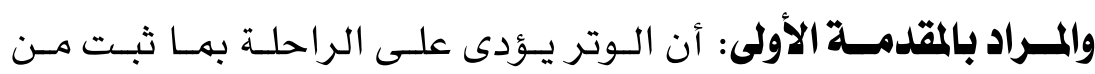

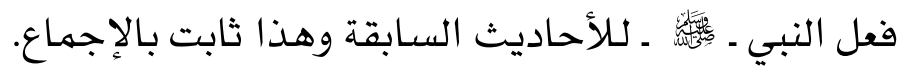

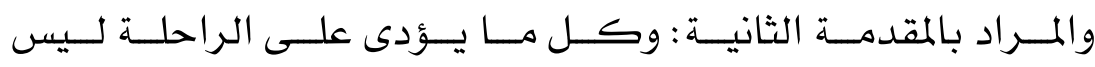

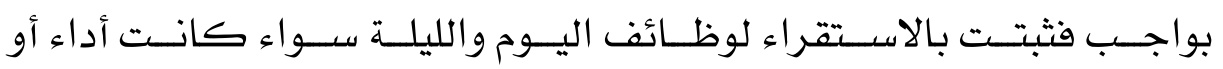

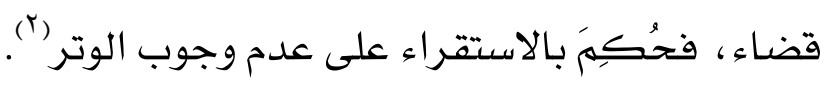
ثانياً: أدلة أبو حنيفة ومن معه القائليز بوجوب الوتر:

$$
\text { استدلوا علي ذلك بعدة أدلة منها : }
$$

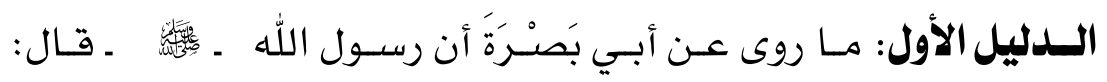

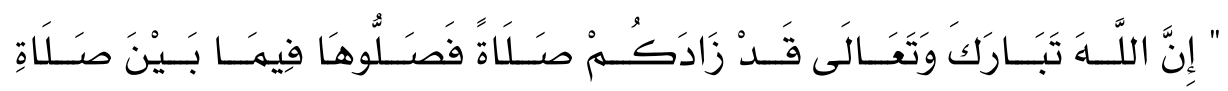

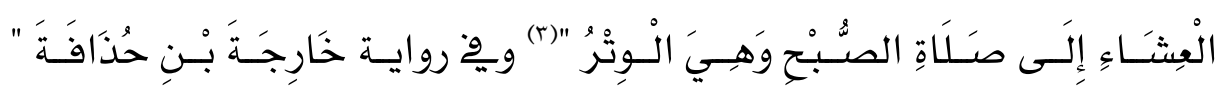

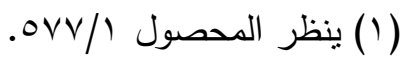

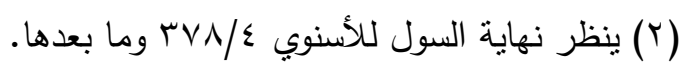

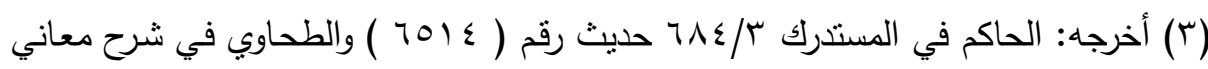

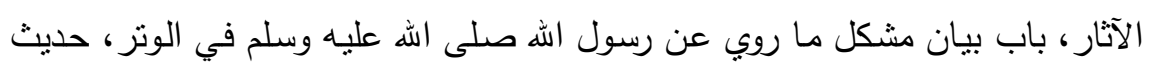
رقم (1) ( ) ).

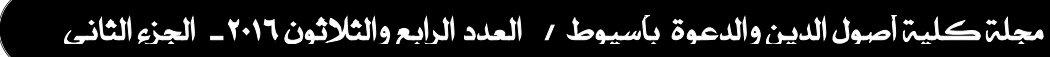




\section{د. عبــــالعظليم مهمسـ أحمهـ}

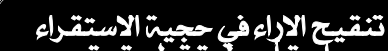

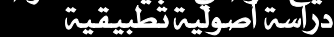

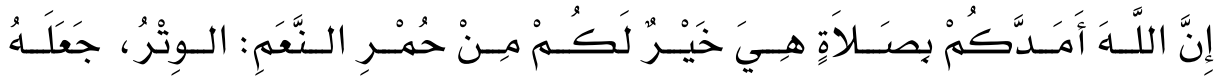

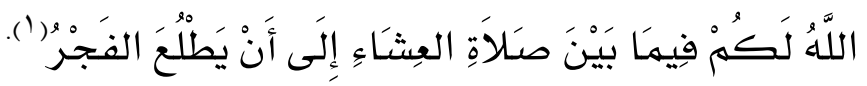

وجه الدلالة من الصديثْ: ووجه الدلالة من الروايتين تظهر من عدة

$$
\text { وجوه (r) ( }
$$

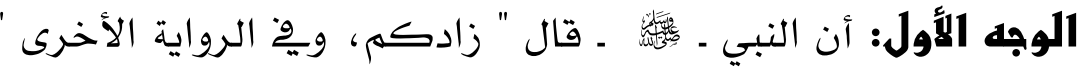

أمدكم" والزيادة والإمداد لا يتحقق إلا ِِّْ الواجبات لأنها محصورة بعدد،

$$
\text { ولا تتحقق بِ النوافل لأنها غير محصورة. }
$$

الوجه الفنانـي: أن الزيادة على الشئ إنها تتحقق إذا كانت من جنس المزيد عليه، والمزيد عليه فرض، فكذلك الزائد، إلا أن الدليل غير قطعي فصار واجباً.

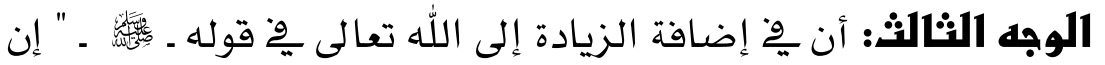

الله قد زادكم" فإضافتها إلى الله تعالى لبيان فرضيتها ، لأن السنن إنها تضاف إلى الرسول ـ .

(1) أخرجه: الترمذي في سننه، أبواب الوتر، باب ما جاء في فضل الوتر حديث رقم (Yor)

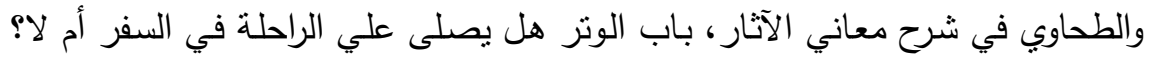

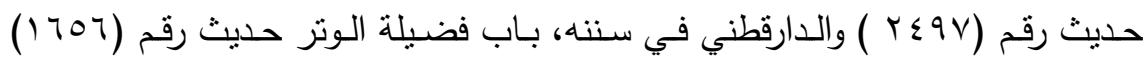

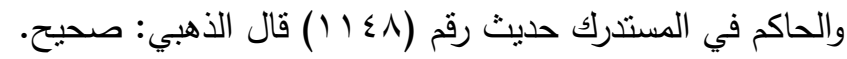

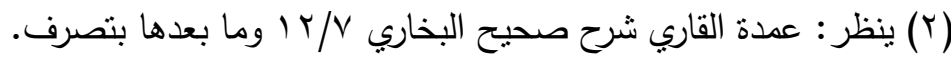




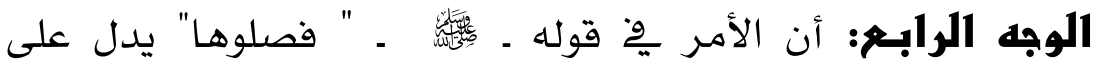

الوجوب، ولا سيما تأكد الأمر بالوتر بهحبة الله إياه بقوله: "فإن الله وتر”

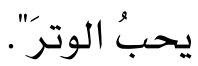




\section{ناقشُ الجمهور هذا 1 الدلبل من وجوهِ منـها:}

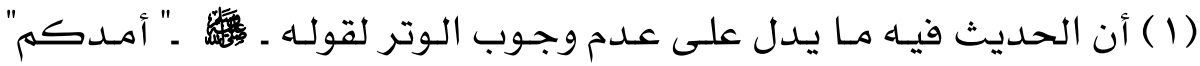
فإن الإمداد هو الزيادة بها يقوى المزيد عليه، فهي نافلة.

(Y) لا نسلم لكم صحة الحديث فتقل الشوكاني: عن المحدثين بعد ذكره

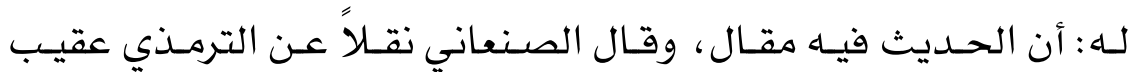
إخر اجها : حديث غريب لا نعرفه إلا من حديث خارجة بن حذافة'(1). وقـد يجـاب عـن ذلـك: بقــول الهـروي: " ... وقول التروـذي: غريـب. لا ينـايخٌ

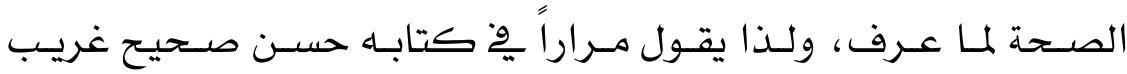

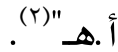

(r) لا نسلم لككم بـأن إضـافتها إلى الله تعـالى وعـدم إضـافتها إلى الرسـول -

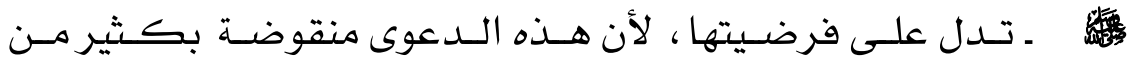
الأحكام ورد فرضيتها على الأمة ومضافة إلى الرسول ـ . .

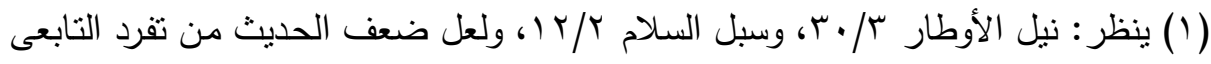
عن الصـحابي: كمـا نقل الهروي. قـال ابن الهمـام: ورواه الحـاكم، وقال: صـحيح ولـم يخرجاه لتقرد التابعي عن الصحابي. ( ينظر : مرقاة المفاتيح شـرح مشكاة المصابيح ب/ ع ع الناشر / دار الفكر ، بيروت - لبنـان

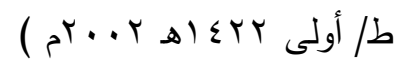

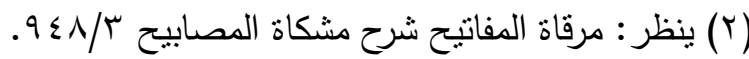


(ع) أنكم قد قلتم بأنها واجبة بأن الدليل على فرضيتها غير قطعي فكانت واجبة ، بأنكم تفرقون بين الفرض والواجب فهذا الفـرق اصطلاحكم

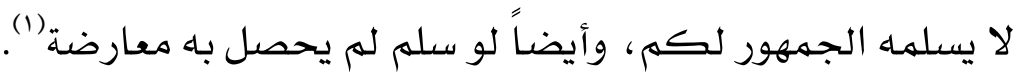

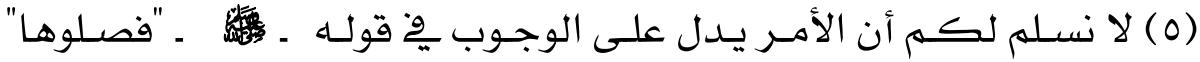

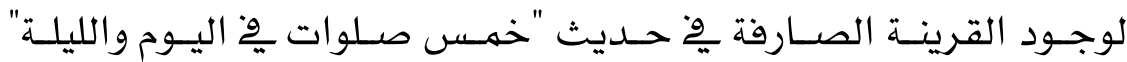
والقرينـة قولـهـ " إلا أن تطـوع " فهـذا يـدل علـى أن غـير الخهـس لـيس

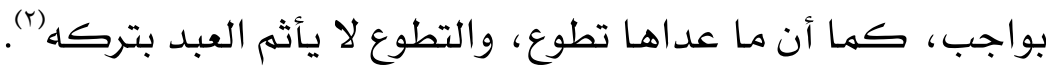

\section{الدليل الثانيي: لاقائلين بالوجوب:}

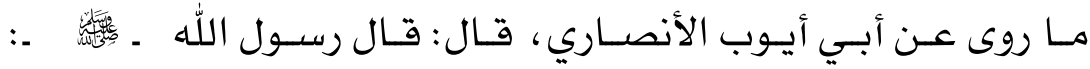

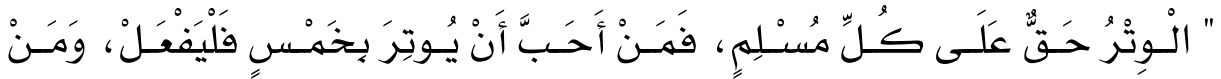

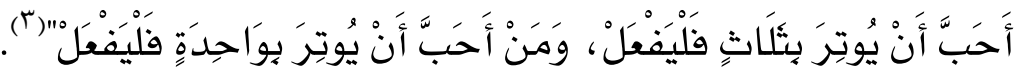

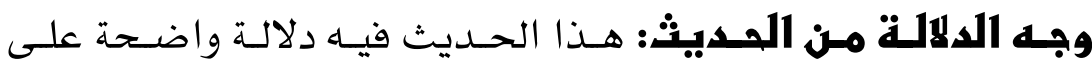

$$
\text { الوجوب؛ لأن معنى قوله " حق " أي واجب علي كل مسلهم. }
$$

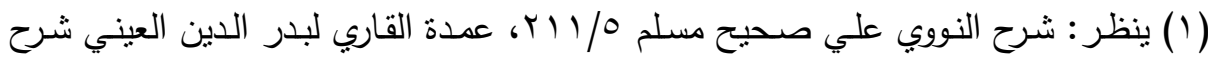

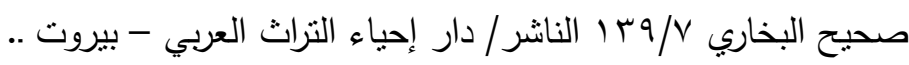

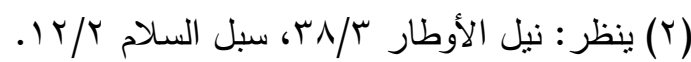

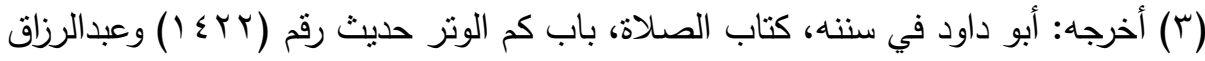

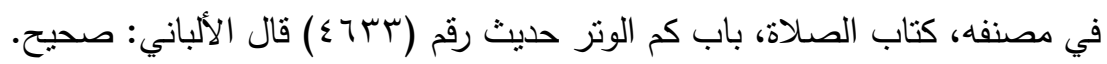


الأول: أن الحديث يدل على مشروعية الإيتار بركعة واحدة، وهذا

بعيد" عن محل النزاع من حيث الوجوب وعدماه لا من حيث عدده ووصله. قال ابنُ عبدالبر بعد ذكره لهذا الحديث: "...وقد شُبِّهَ على قوم من متقدمي الفقهاء مثل هذا الحديث وَشَبَهُهُهُ فقالوا الوتر واجب ... ثم قال: وِِّ حديث الأعرابي يِّ الخمس صلوات هل عليَّ غيرها يا رسول الله فقال رسول

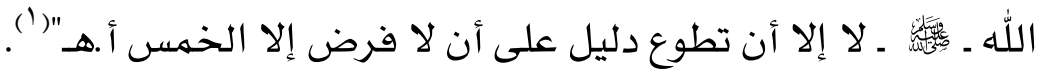

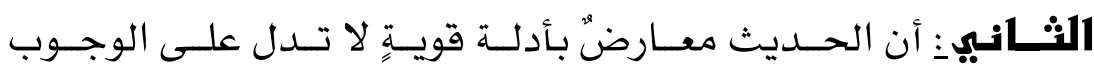

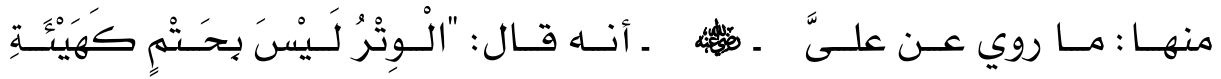

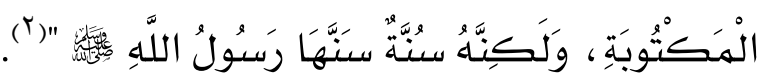

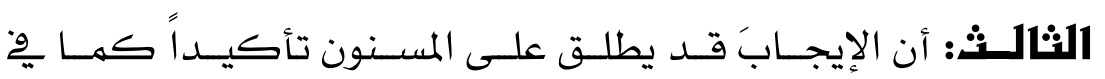

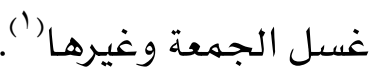

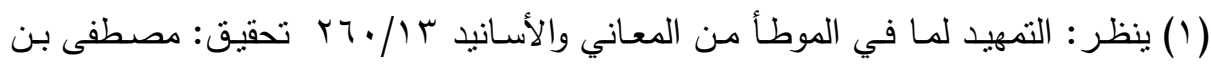

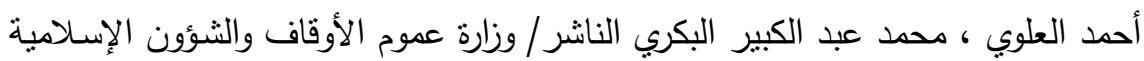

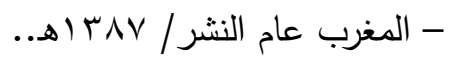

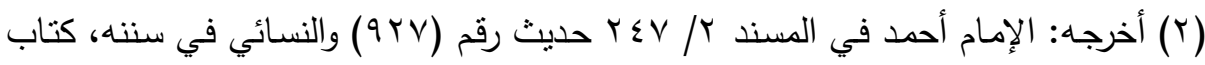

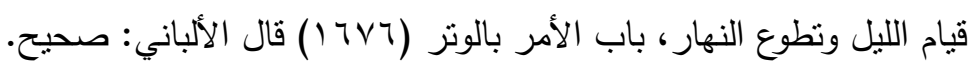

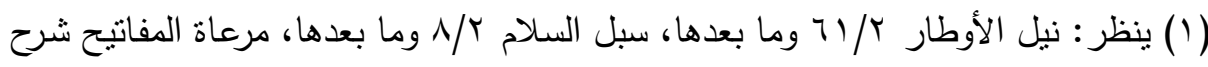

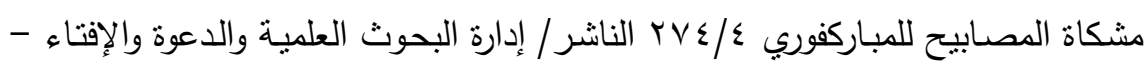

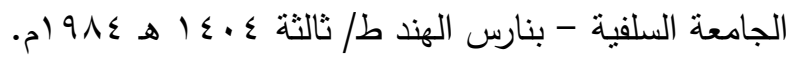




\section{الدليل الثالثْ: لاقائلين بالوجوب:}

أن صــلاة الـوتر لهـا صـفـات الصــلاة المفروضـة ، مـن حيـث وجـوب

$$
\text { القضاء بالإجماع، ومؤقتة فتجب كالمغرب ('). }
$$

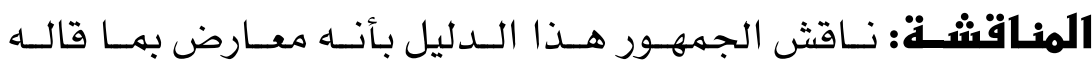

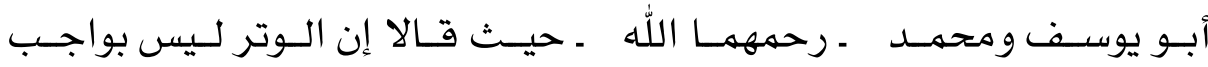

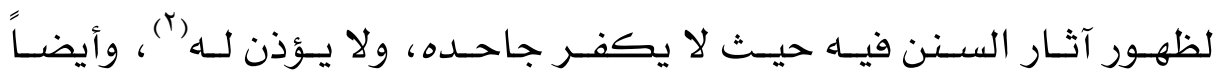

مــا ذكــره ابــن قدامسة مثثل هــذا حيـث قــال، ولأنــه يجــوز فعلــه علـى

$$
\text { الر احلة من غير ضرورة فلم يكن واجباً كالسنن ') . }
$$

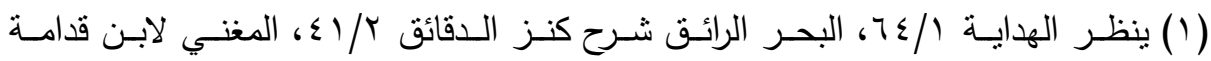

$$
\text { شرح النووي علي صحيح مسلم 11/4 وما بعدها. }
$$

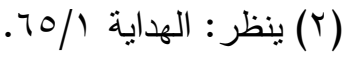

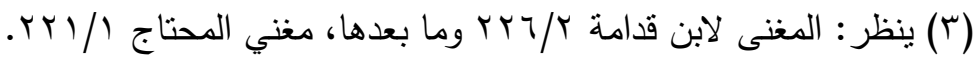




\section{الر}

يتـبـين مهــا ســـق أن الــراجح مــذهب الجمهــور القـائلين بســـنة

الوتر وذلك لما يأتي:

أولاً: أن الأحاديث التي استدل بها الحنفية ثبت ضعف بعضها، وإن

صحت فهي محمولة على التأكيد وتكلم المحدثون فيها كها تقدم.

ثانياً: أن الإمام أبا حنيفة قال لا يكفر جاحده؛ لأن وجوبه ثبت

بالسنة، وهذا متفق عليه بين من قال بأنه سنة، ومن قال بأنه فرضٌ أو واجبٌ، فلو كان الوتر فرضاً أو واجباً لكفر جاحده.

ثالثاً: أن ما استدل به الجمهور من الأحاديث ثبت صحتها عند علماء الحديث، وهي أدلة ِِّ غاية القوة، أها أدلة الإمام أبو حنيفة وإن ثبت أن لها حكم الرفع إلا أنها لا تقاوم الأدلة الدالة على عدم الإيجاب، كها

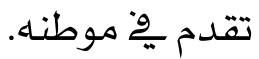

رابـعاً: ما نقله الشوكاني ِِّْ نيل الأوطار معزياً إلى ابن المنذر من أنَّ أبا حنيفة لم يوافقه أحدٌ ِِّْ ذلك يؤكد ما سبق قوله من المرجحات. 


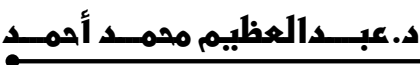

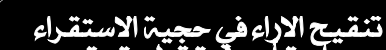

درأستا اصوليتة تطبيقيتشاعلان

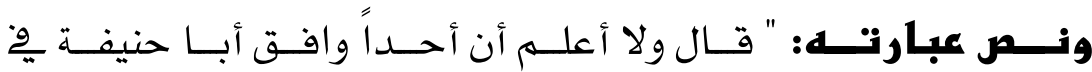

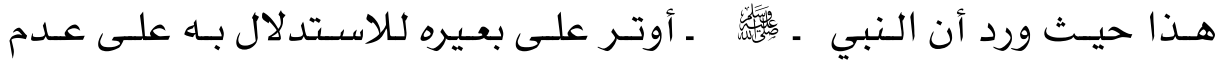
الوجوب؛ لأن الفريضة لا تصلى على الراحلة أ.هـ"(').

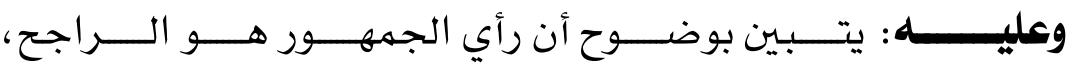

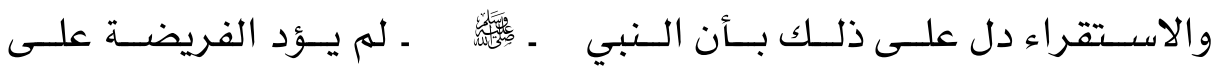
الراحلة باستقراء وظائف اليوم والليلة أداءً وقضاءًاء).

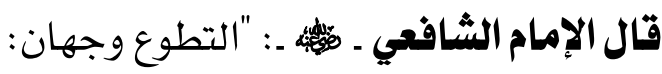

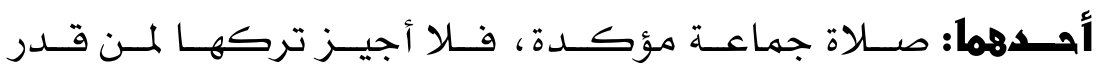
عليها ،وهي: صلاة العيدين ، وخسوف الشمس والقمر، والاستسقاء.

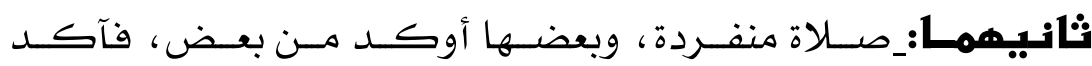
ذلـك الـوتر ، ويشـبه أن يكـون صــلاة التهجــد ، ثـم ركعتــا الفجـر، قــال:

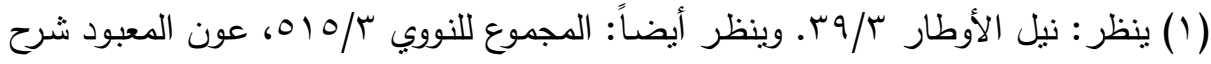

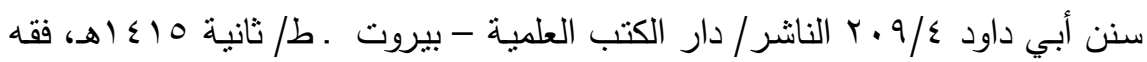

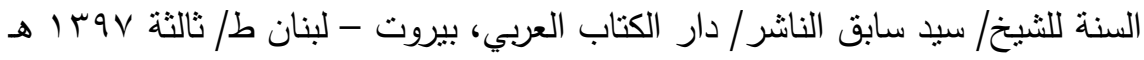

$$
\text { . } 19 \vee V
$$

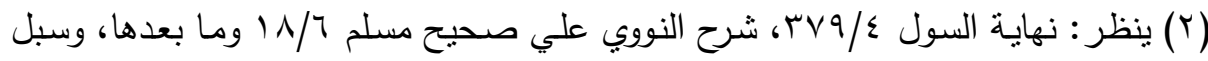

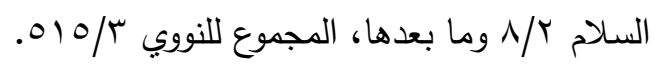

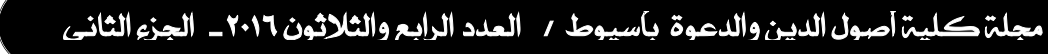




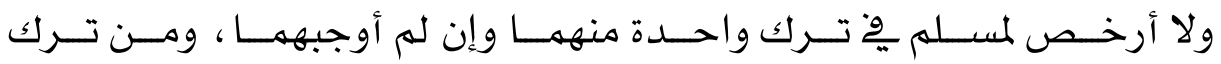

واحدة منهما أسوأ حالاً مهن ترك جميع النوافل أ.هـ"( ().

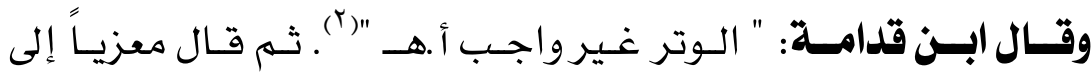

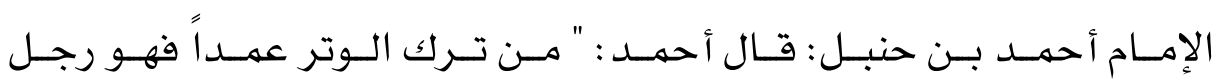

سوء، ولا ينبغي أن تقبل له شهادة وأراد المبالغة ِوْ تأكيده أ هـ "(").

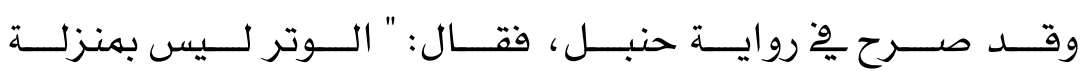

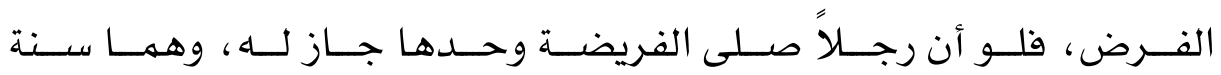

مؤكـــدة؛ الركعتــان قبـلـل الفجــر والـوتر ، فـإن شــاء قضـــى الـوتر، وإن

شاء له يقضـه، وليس هما بهنزلة المكتوبة أ.هـ (ع).

ومــن نظــر إلى مــا ســـق يــرى أن بعـض الحنفيـة كـالإمــام أبـي

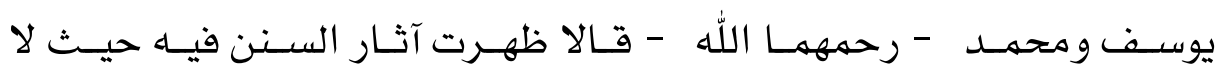

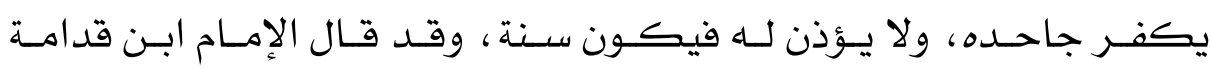

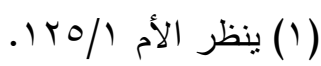

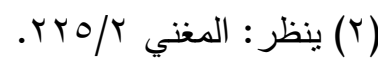

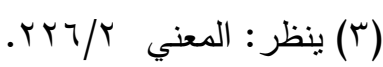

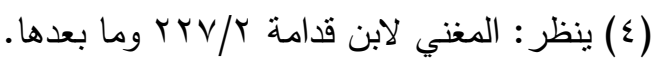

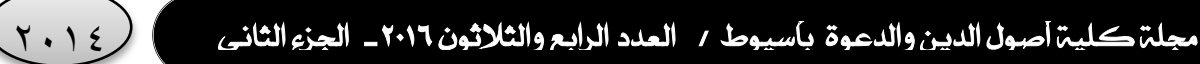


مثتل هـذا حيـث قـال: ولأنـه يجـوز فعلـه علـى الراحلـة مـن غـير ضـرورة فلـم

يكن واجباً، كالسنن (')

نخلــص مهــا تقــدم: ثبـوت أثـر الاســتقراء عنــد جُـلِّ الأئهــة ، وإن

كــان وجــد خــلاف مــن الـبعض كــأبي حنيفــة ومــن معــه إلا أن هــذا

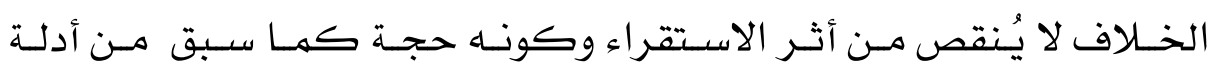

والله أعله بالصواب.

الجمهور.

\section{المطلب الثاني}

\section{أثر الاستقراي في أحكام القضاي}

وهـهـا يــل علـي أهميـة الاسـتقراء واهتمــام العلهـاء بـهـ، حيـث إنــه

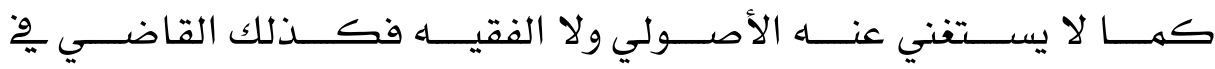

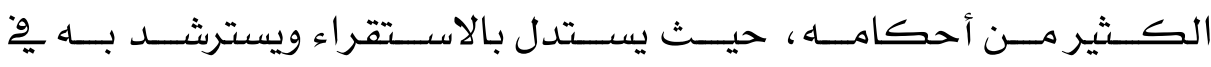

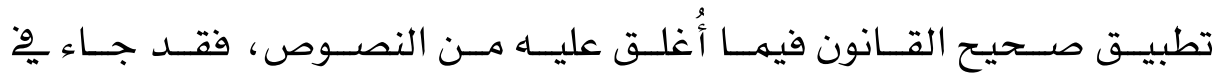

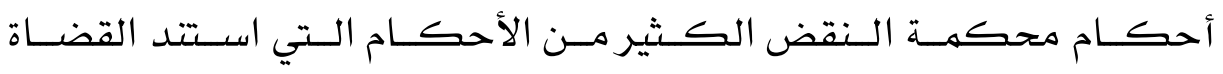

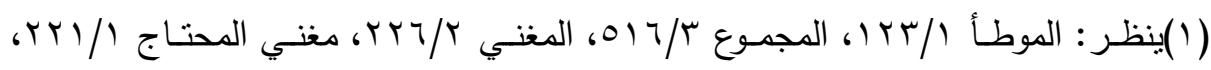

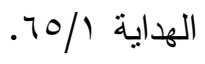


فيهـا إلـي الاسـتقراء، وســبيوا أحسكـامهم بنـاءً علـي مـا توصـلوا إليــه مـن

الاســتقراء ِوْ نصــوص القـانون، وســأتتاول بعضــها علـي ســبيل المثــال لا الحصر يِّ الفروع الآتية :

\section{الفر ع الآول \\ أنثر الاسن:قراء في أمكام الأسرة}

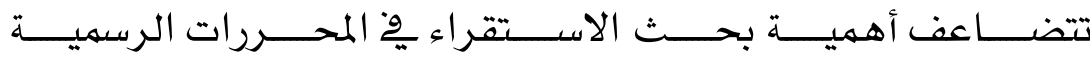

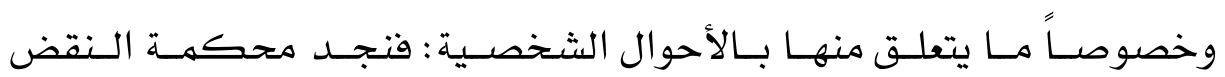

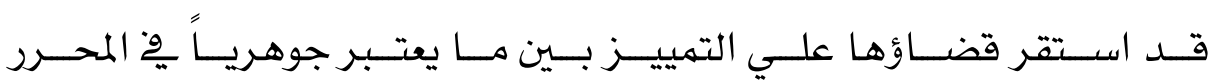

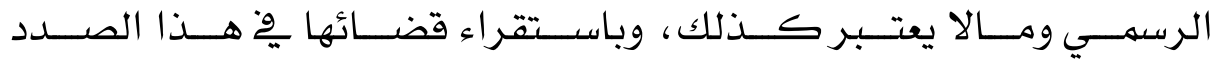
نجـدهـا تحـدد مــدى جوهـريـة البيـان علـي ضـوء الغـرض الـذي أعـد المحسرر لإثباته.

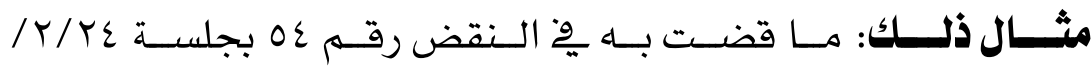

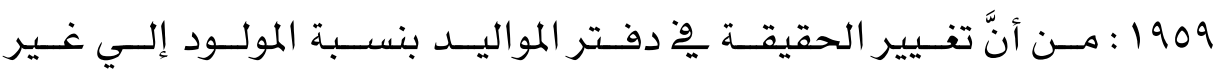

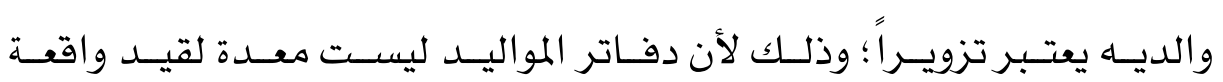
الـولادة مجـردة عـن شخصــية المولـود واسهـي الوالــدين المنتســب إليههــا. وحتى تكون صالحة للاستشهاد بها يخ مقام إثبات النسب . 


\section{د.عبـــالعظليم محمـــ أحمـــ}

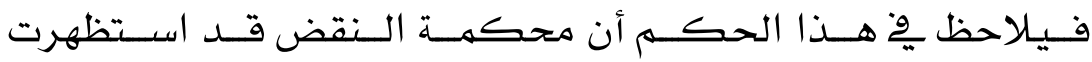

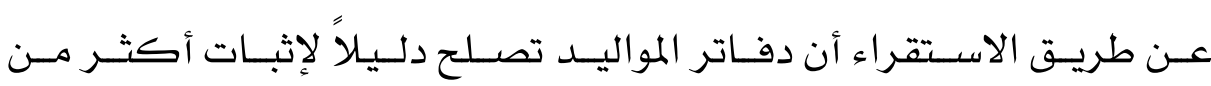
واقعة هي الولادة، وشخصية المولود، ونسبه (').

\section{الفزر ع الفناني}

\section{أثر 1اسنتقراء في الأحكام الإداربة}

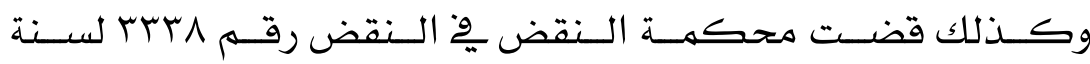

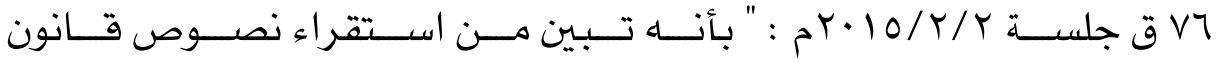

المرافـــات المنظهــة لقواعـــ وضــوابط الإعلانـات والاختصـــاص المحلـي أنَّ الأصـل أنَّ كـل مكــان يصـح إعــلان المـدعى عليـهـ فيـهـ قانونـاً يُعـدُ موطنـاً

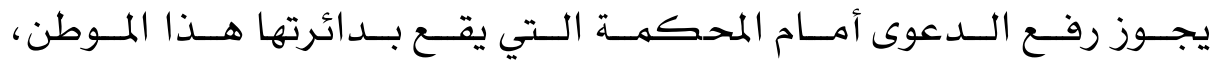
ســواءُ كـــان المــوطن العـام أو القــانوني، أو مــوطن الأعمـــال، أو المــوطن

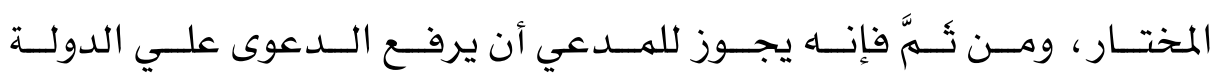
والأشــخاص الاعتباريـة العامـة أمـام المحككهـة الـتي يقـع بـــائرتها مــوطن

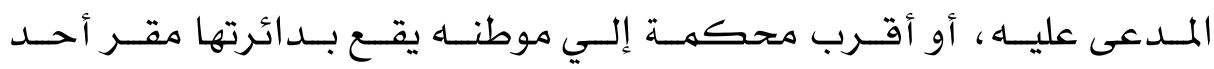

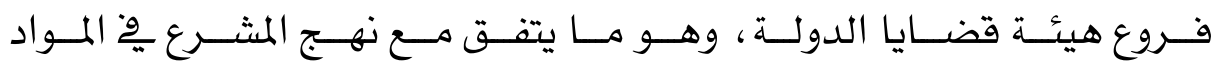

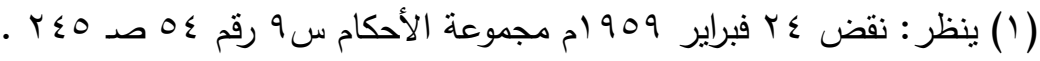




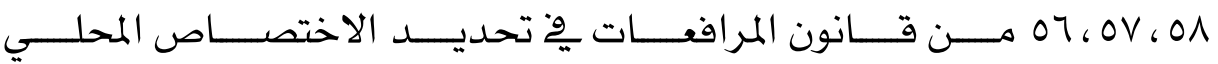

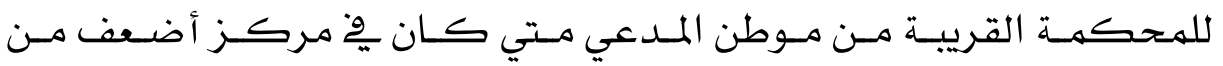
مركـز المـدعى عليـها بهـا يجعلـهـ أولى بالرعايـة ، إذ ككـان الثابـت الـذي لا

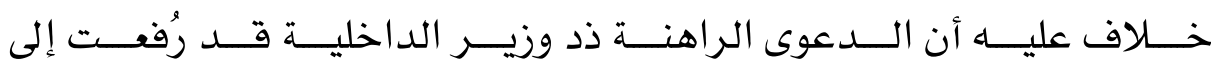
محككهـة أسـيوط الابتد ائيـة الـتي يقــع بـد ائرتها فـرع هيكـة قضــايا الدولـة

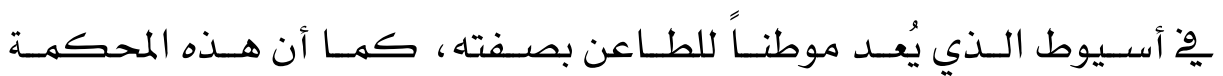
هــي أقـرب محكهــة لمـوطن المطعـون ضــده، فـإن الــدعوى تككـون قـد

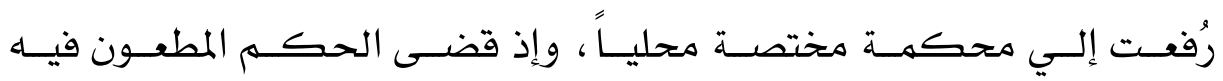
بـرفض الــف بع بـدم اختصــاص محكهــة أسـيوط الابتدائيسة محليـاً بنظـر

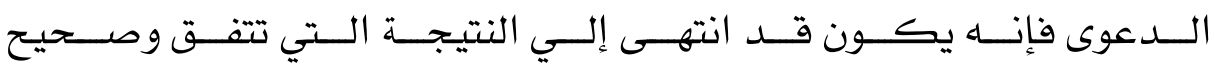

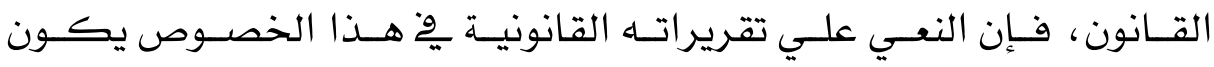
غير منتج ولا جدوى منـه ، ومن ثم غير مقبول " ( ').

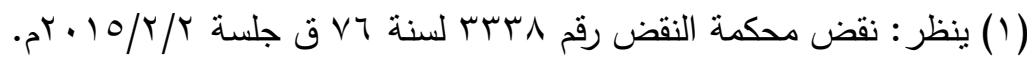




\section{الفر ع الثالث}

\section{أثر الاستقراء في الأمكام الجنائية}

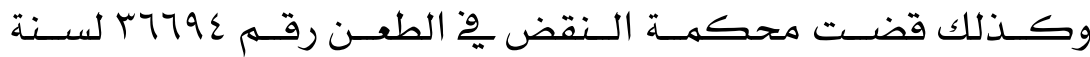

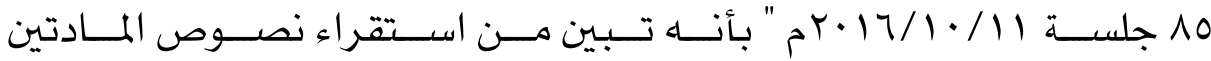

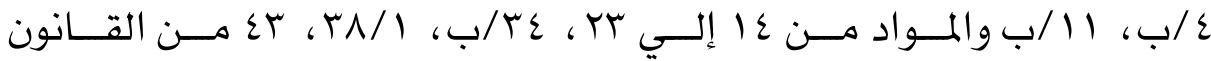

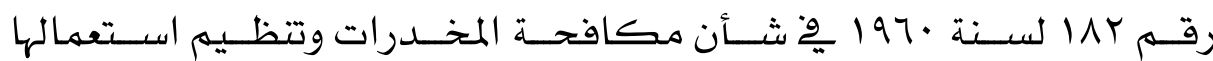

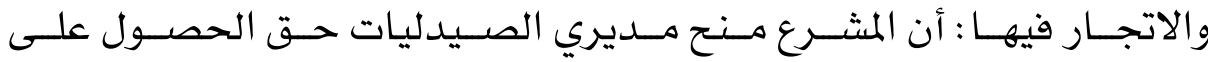

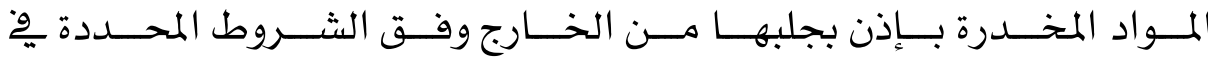
القـانون، أو بالشـراء مــن الأشــخاص المـرخص لهـهم بالاتجــار فيهـا ، فــإذا حصـلوا علـي تلــك المــواد بغـير ذلــك الطريـق فـإن إحـــرازهمه، أو حيــازتهم

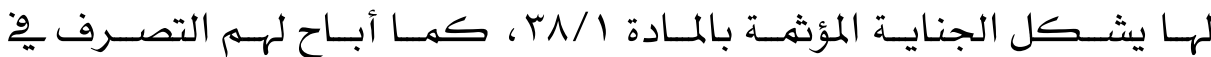

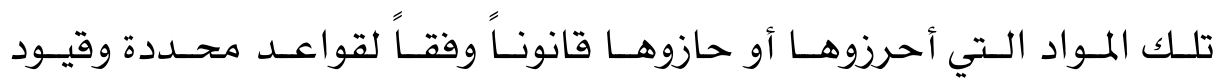

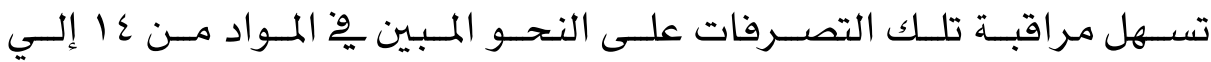

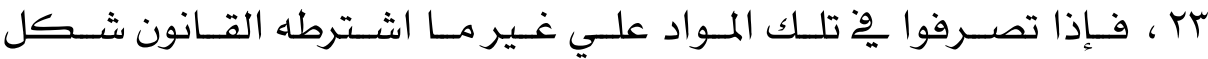

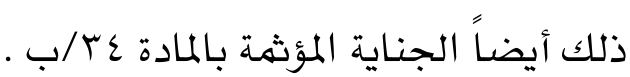
أمــا إذا اقتصـــر الأمــر علـى عــدم إمســاك الـــفاتر المنصـــوص

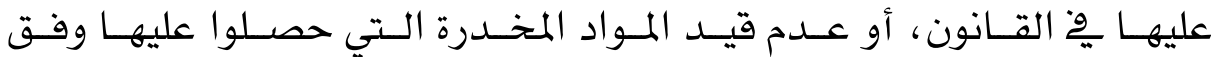


أحككـام القـانون، أو عـدم إرســال الكشـوف المنصــوص عليهـا مِ المـادة

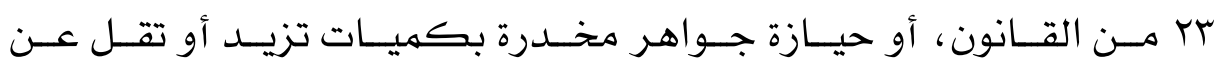
الكميـات النـاتجــة عـن تعـدد عمليـات الــوزن ، فـإن ذلـك يشـكل الجنحـة

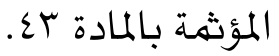

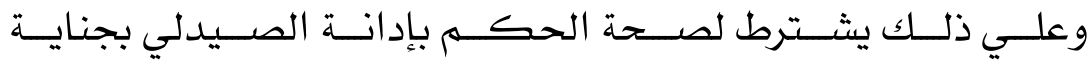

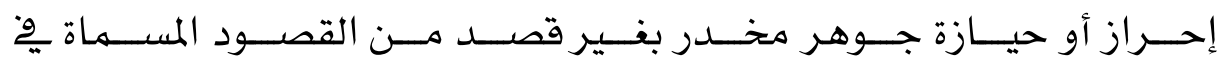
القـانون أن يـبيـن أنــه حصـل علـي المــواد المخــدرة المضــبوطة بغـيـر الطريـق

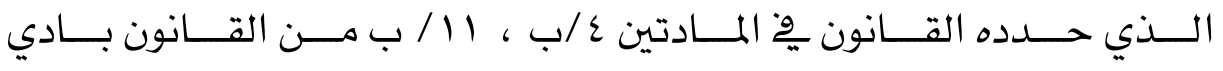
الذكر.

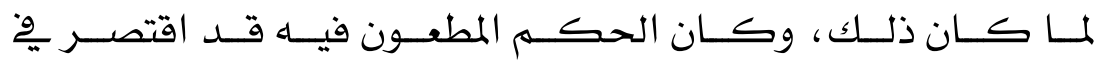
إطــراح دفّاع الطـاعن القـائم علـي أنــه مـرخص لـه بــإحراز وحيـازة المــواد

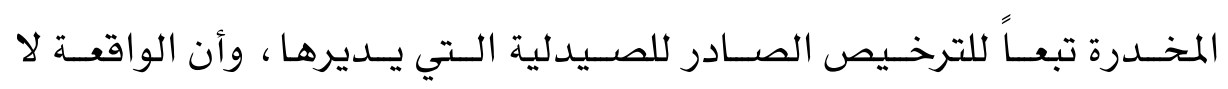
تعــدو أن تككـون مجـــرد مخالفــة لعـــدم إمســـاكـه دوفـاتر لقيــد المــواد

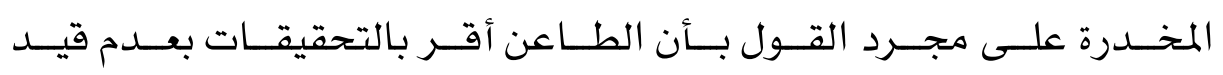
المضــبوطات بالــفاتر ، ودانــه بـإحراز المخــدر المضــبوط بغـير قصــد مـن

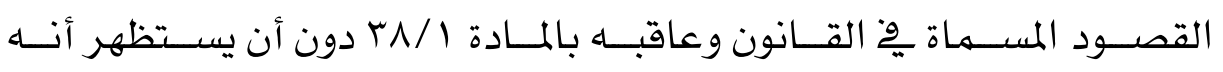

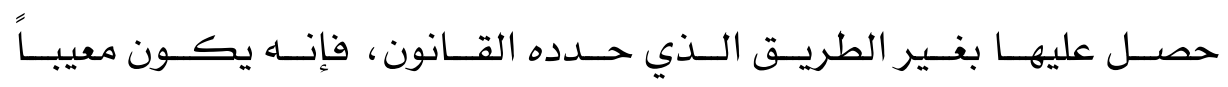


بالقصــور بهـا يوجسب نقضــه والإعـادة بغـير حاجــة إلى بحست بـاقي أوجــه

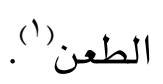

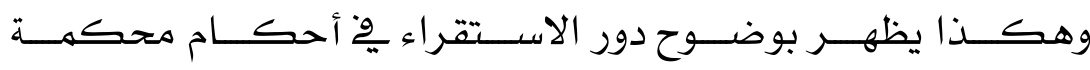

النقض مها يدل علي أهميته ، ومدي الاحتياج إليه. 


\section{الخاتمبهة}

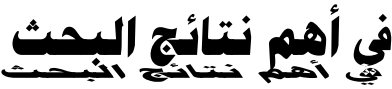

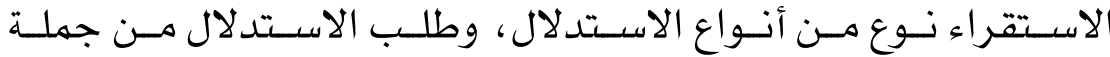

الطــرق الموصـلة للأحسكـام، فالاسـتقراء هـــو أحسـ الأدلـة المختلـف فيهـا،

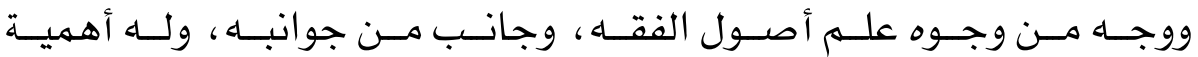

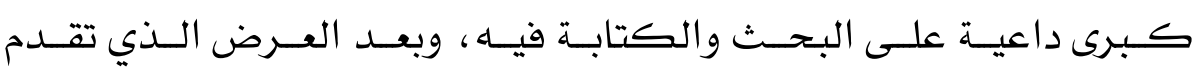

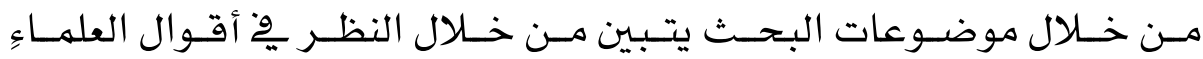

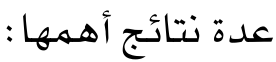

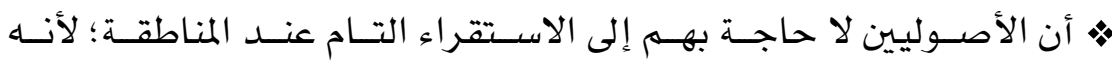

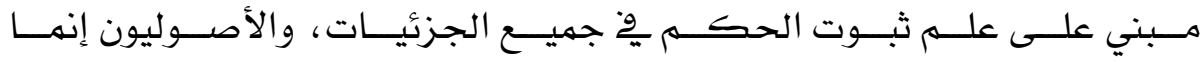

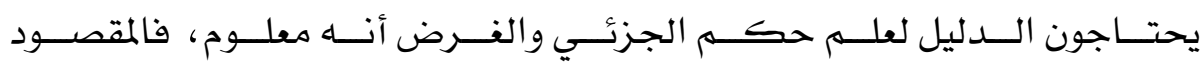

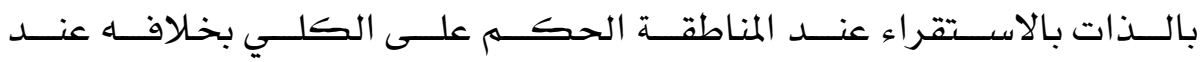
الأصوليين فإنه الحكم على الجزئي لتعلق غرضهم بأحكام الجزئيات.

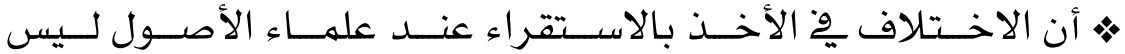

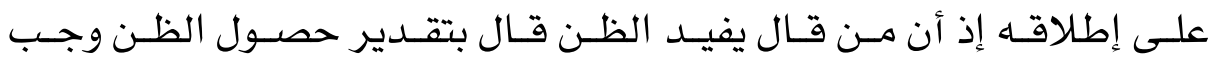

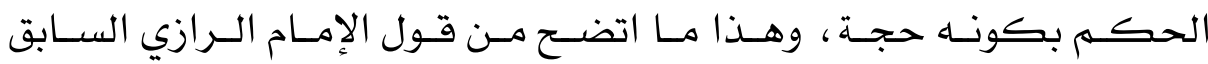

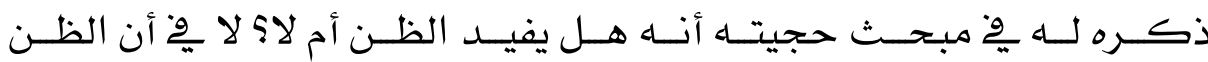

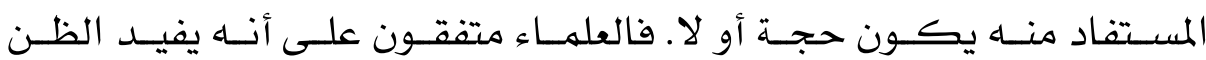

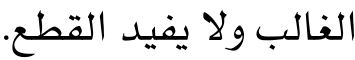


* أنَّ الناظر مِّ معظم الفروع يرى أن القائلين بأنه يفيد الظن يأخذون به ، فالحنفية يذكرون الاستقراء يٌْ معرض الاستدلال للأحكام الشرعية، ، فهن ذلك ما ذكروه يخ سبدات التلاوة نافين وجود سـدة ثانية ِوْ سورة

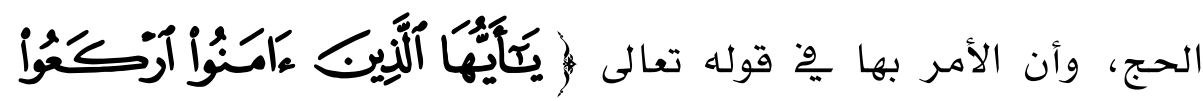

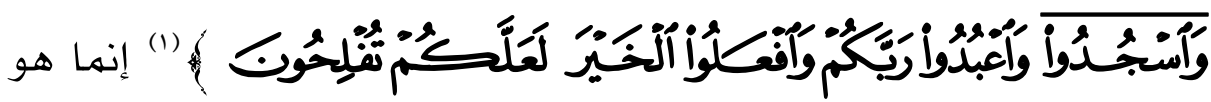

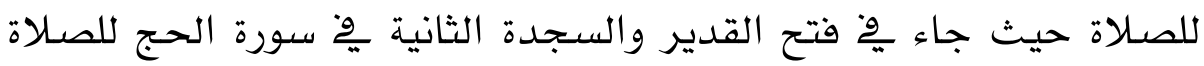
عندنا ، لأنها مقرونة بالأمر بالركوع، والمعهود ِوْ مثله من القرآن كونه من أوامر ما هو ركن الصسلاة بالاستقراء (r).

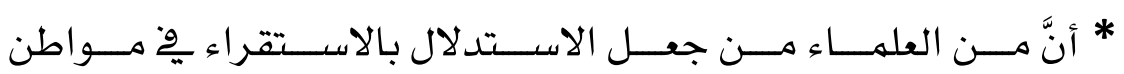
كـثيرة مختلفـة لـه حكــم الصـيفة وِّ إثبـات العهـوم كالإمـام الشـاطبي وٌْ الموافقـات كهـا سـبق ذكـر ذلـك لـه عنـــ بيـان موقفـهـ مـن الاسـتقراء

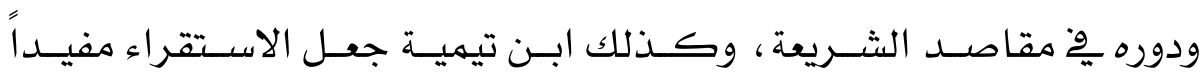
للقطع كها سبق ذكره له.

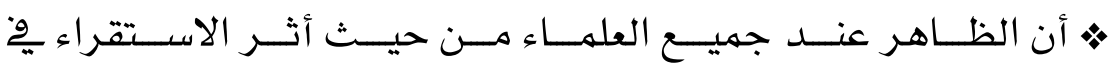

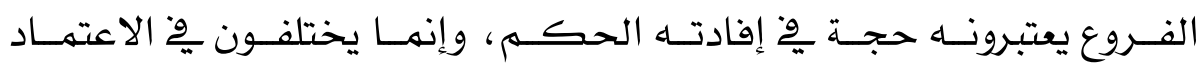
عليه.

$$
\begin{aligned}
& \text { ( (l) جزء من الآية (YV) من سورة الحج . }
\end{aligned}
$$

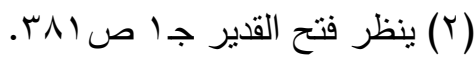


• ارتبـاط الاسـتقراء بـالكثير مـن الأحسداث والوقـائع المتجــددة ، والـتي

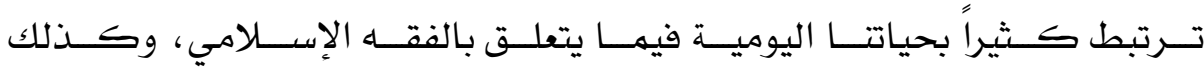

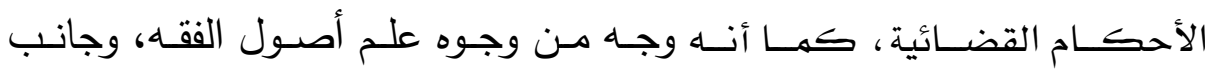
من جوانبه، وفيه جلاء لكثير من المسائل المختلف فيها.

والهه أعلم بالصواب. 


\section{|الفهارس}

\section{أولاً: فهرس أهم المصادر والمراجع حسبـ الترتيب الأبهدي.}

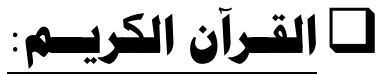

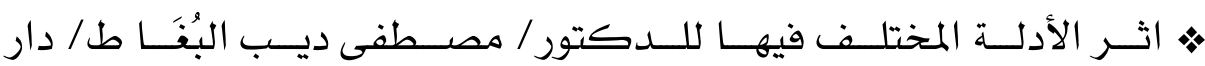
العلوم الإنسانية - دمشق حليوني.

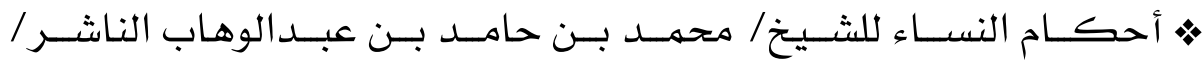

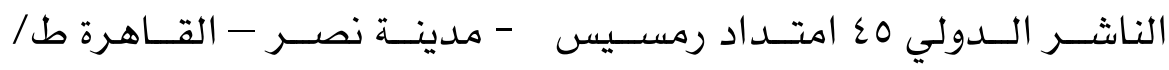

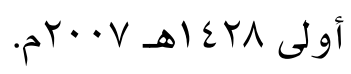

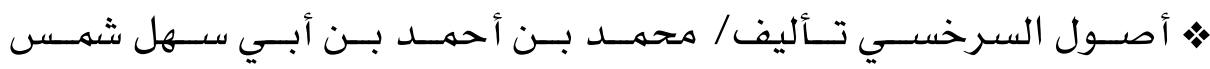
الأئهة السرخسي (المتوفى: بـعهـ) الناشر : دار المعرفة - بيروت ـ.

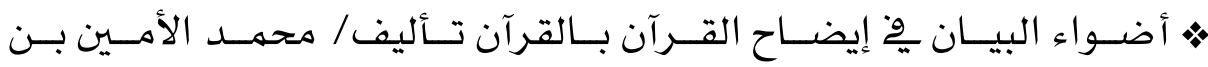

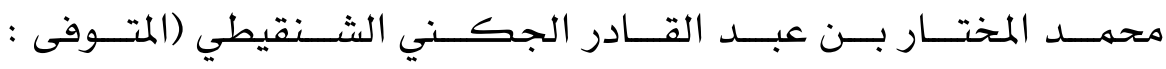

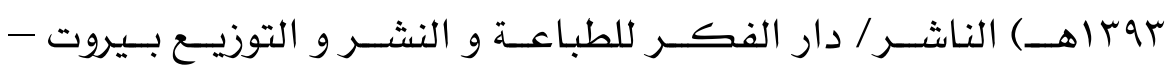

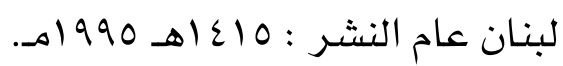

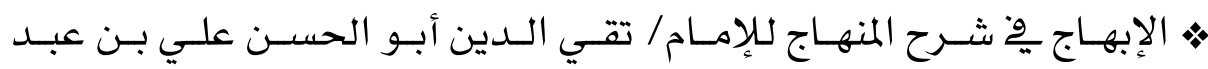

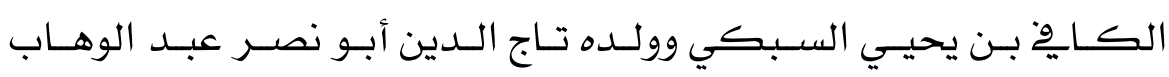
الناشر / مكتبة الكليات الأزهرية بدون. 


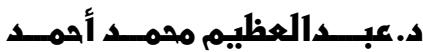

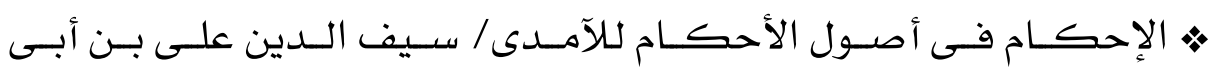

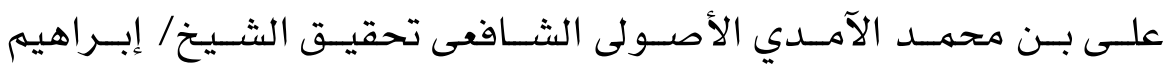

$$
\text { العجوز ط/ دار الكتب العلمية - ل }
$$

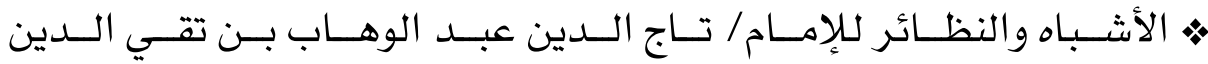

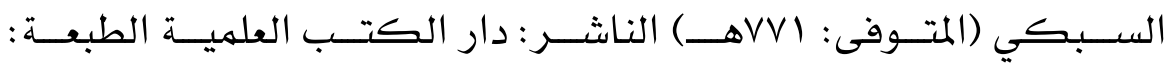

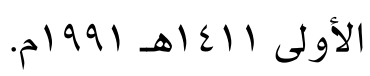

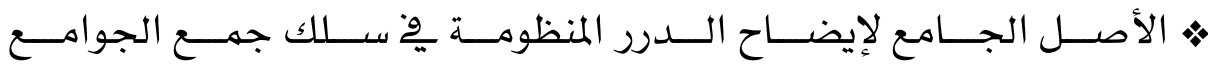

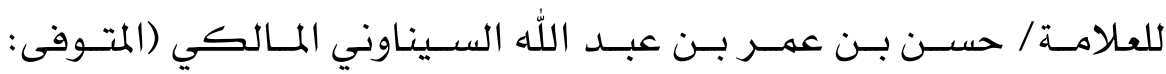

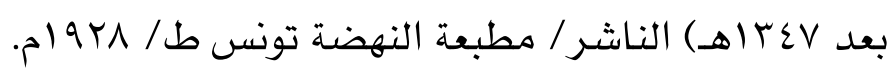

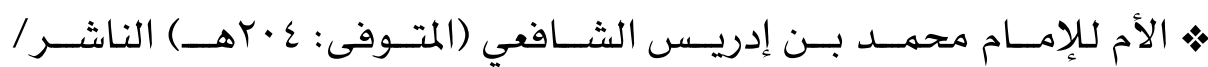

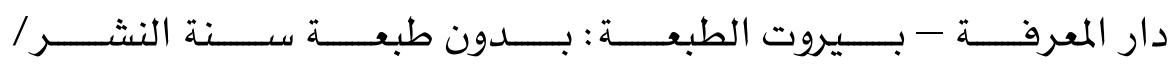

$$
\text { . 199. أهـ. }
$$

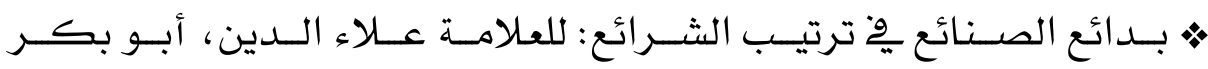

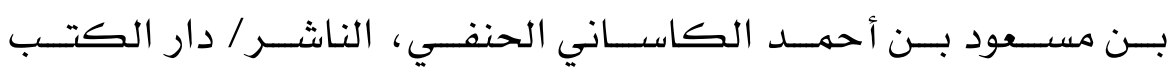

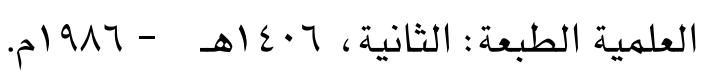

هـ البـحـر الرائق شـرح كنـز الـدقائق للعـلامـة / زيـن الـدين بـن إبـراهيم بـن محهــد ، المعـروف بـابن نجـيم المصــري (المتـوفى: ·لوهـــ الناشـر / دار الكتاب الإسـلامي ط/ ثانية - بدون تاريخ. 


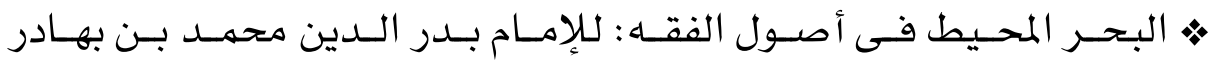

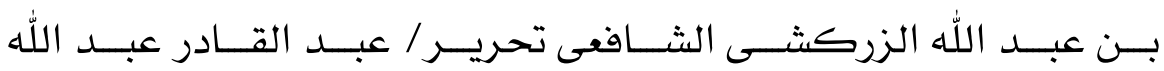

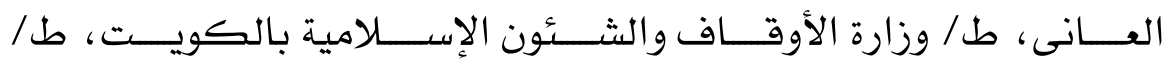

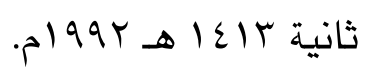

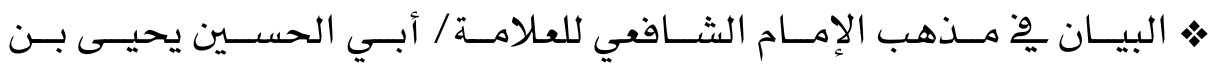
أبـي الخــير بـن ســالم العهرانـي الثــافعي (المتـوفى: 001هـــ تحقيـق/

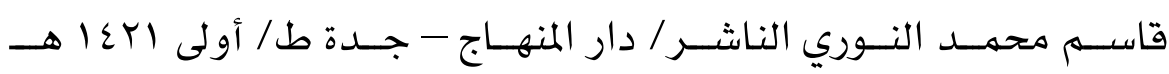

$$
\text { . م }
$$

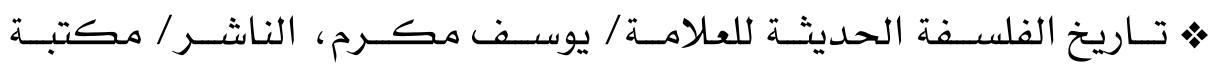
الدراسـات الفلسفية

\section{الطبعة : الخامسـة.}

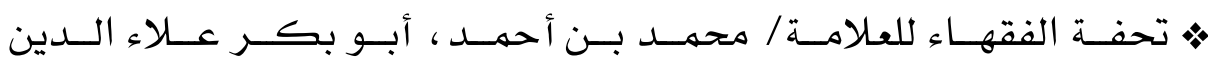

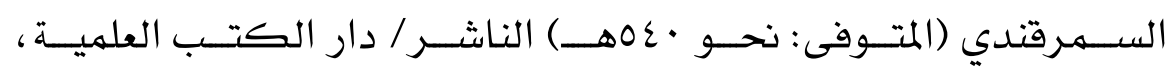

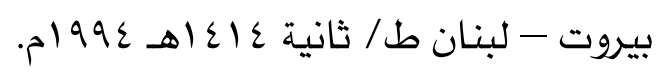

ثم تقسـير البيضــاوي المسـهى ـ أنـوار التـزيـل وأسـرار التأويـل ـ للإمـام/

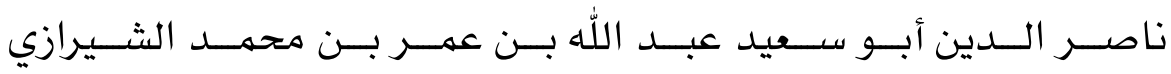

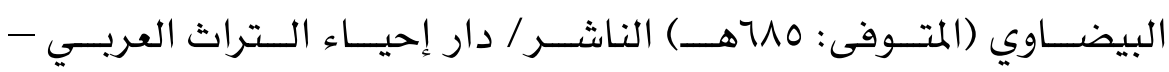

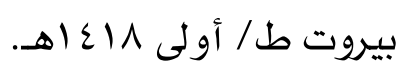




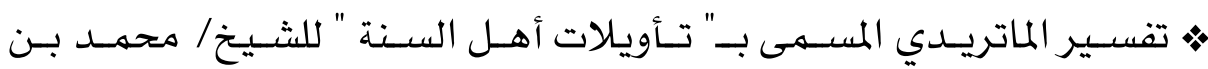

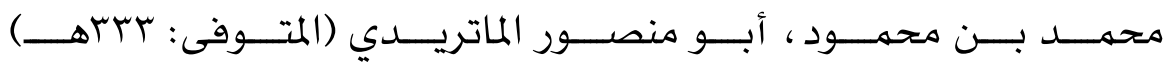
تحقيقد / مجدي باسلوم

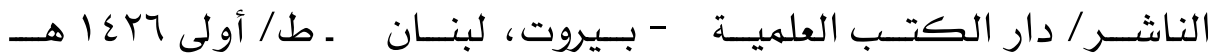

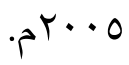

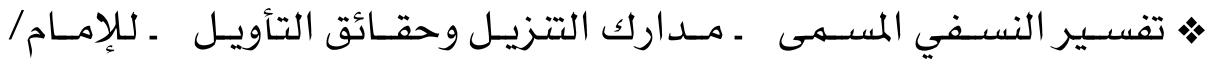
أبـي البركــات عبــد اللهه بـن أحهـــ بـن محمـود حـافظ الـدين النسـفي

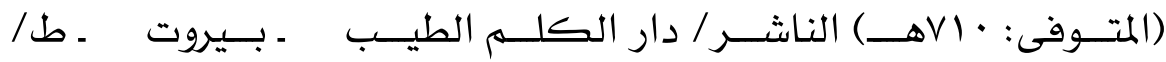

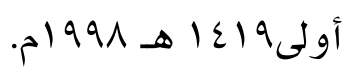

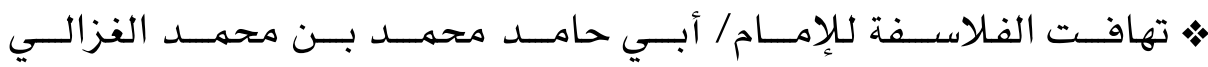

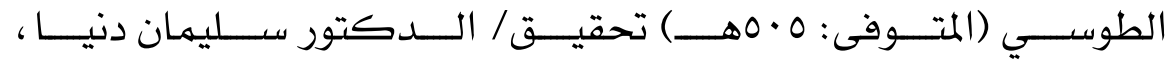
الناشـر/ دار المعارف، القاهرة - مصر ـ ط/ سـادسة. هـ تهـذيب اللغــة للعـلامــة/ محمــد بـن أحمـــ بــن الأزهــري الهـروي، أبــو

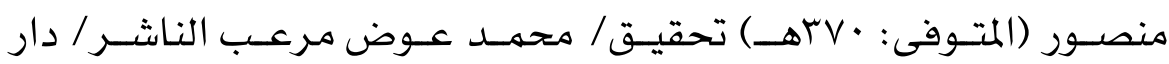

$$
\begin{aligned}
& \text { إحياء التراث العربي - بيروت } \\
& \text { ط/ أولى l • • م. }
\end{aligned}
$$

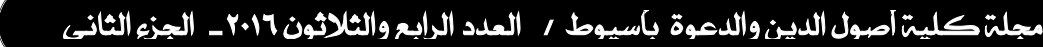




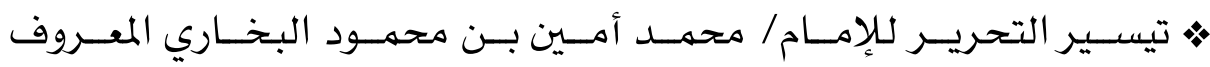

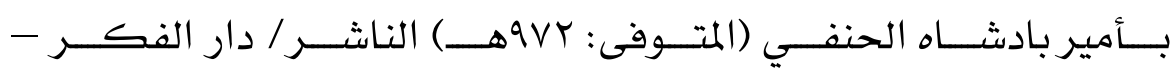

بيروت - م

هـ التقســير الكــبير للإهــام فخـــر الــدين الــرازي النـاشــر / دار إحيــاء التراث العربي - بيروت الطبعة: الثالثة - .بعا هـ، .

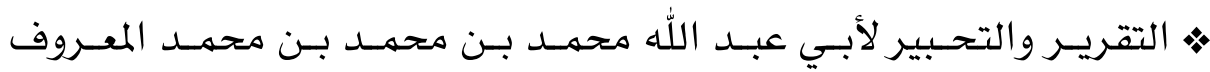

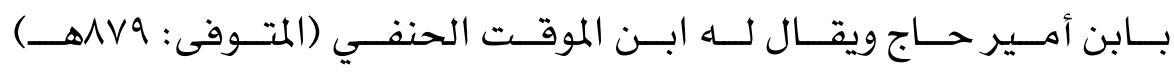
الناشر / دار الكتب العلمية

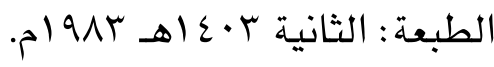

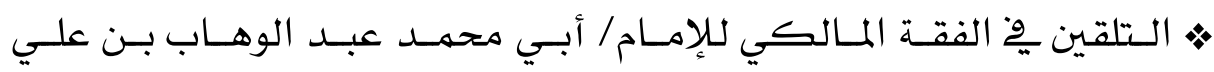
بـن نصــر الـثلبي البغــدادي المـالكي (المتـوفى: ب بعهـ) تحقيـق / أبـي

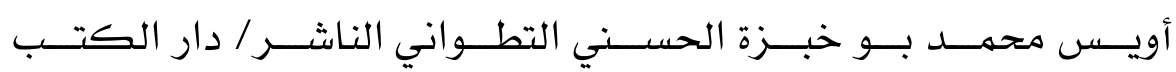

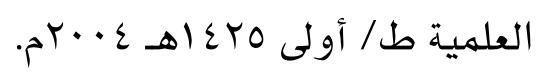

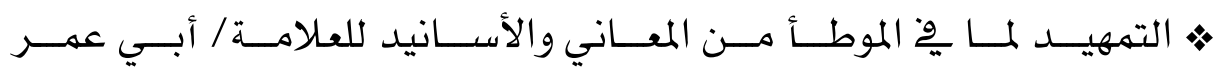

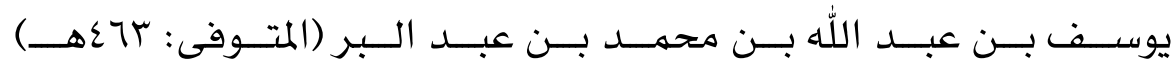
تحقيـق/ مصــطى بـن أحمـد العلـوي ، محمهـد عبـــ الكـبير البكـري الناشـر/ وزارة عموم الأوقاف والثؤون الإسـلامية - المغرب الثوية

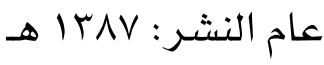




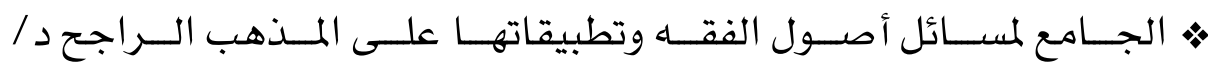

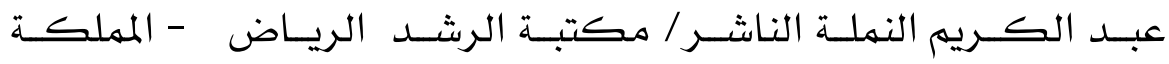

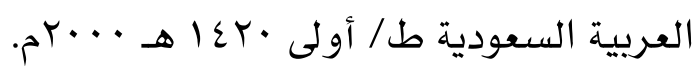

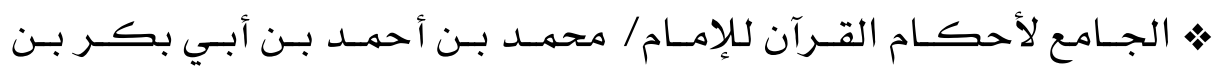

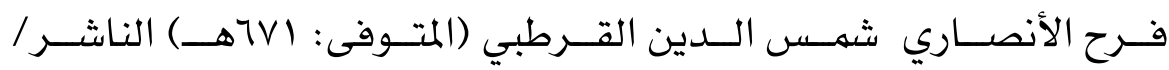

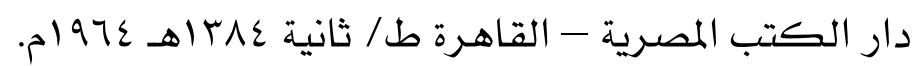

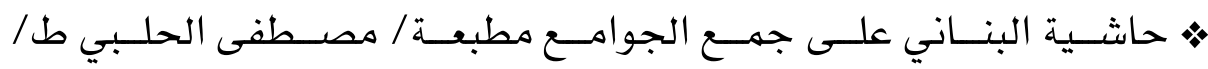

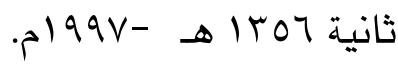

• حاشــية الطحطــاوي علـى مراقـي الفـلاح شــرح نـور الإيضــاح للعلامـة/

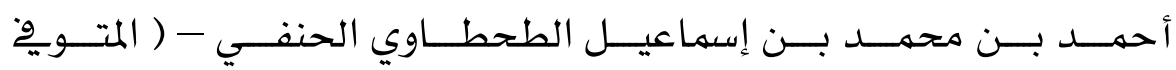

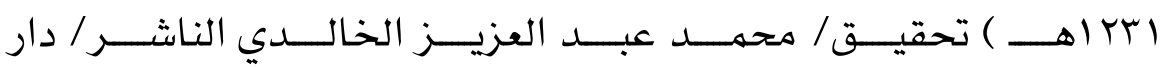

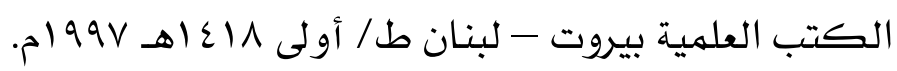

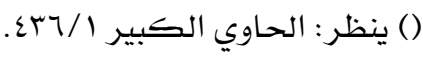

* حاشـية العطـار على شـرح الجــلال المحلـي على جهـع الجواهـع للإهـام/

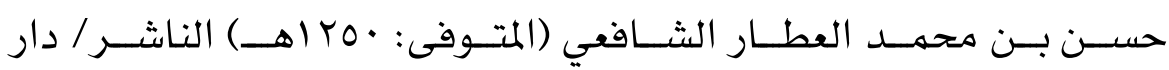

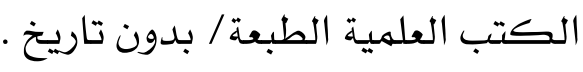

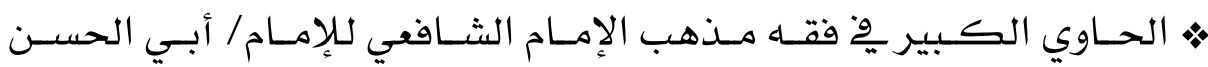

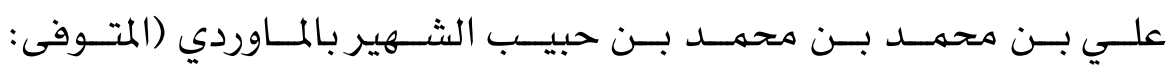




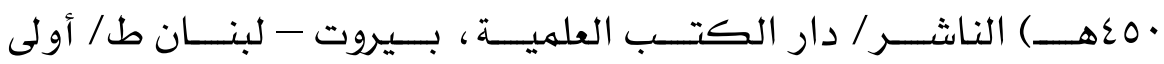
م 1999_ 1219

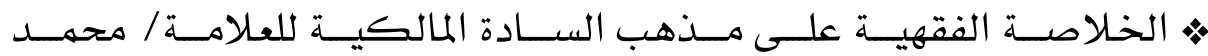
العربي القروي الناشر / دار الكتب العلمية - بيروت ـ.

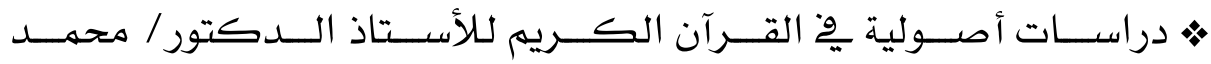

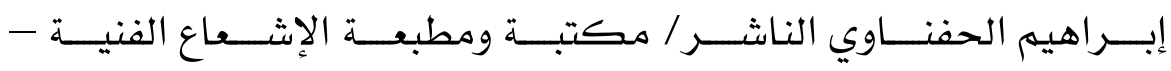

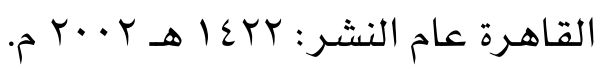

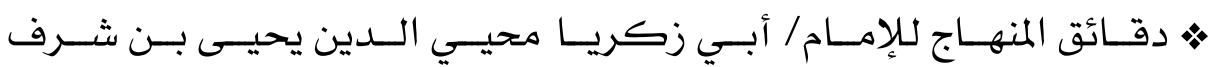

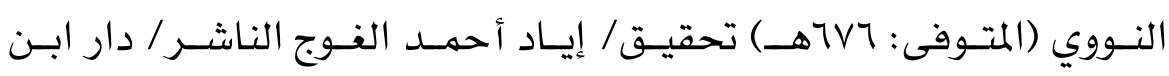

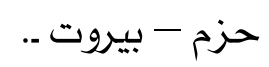

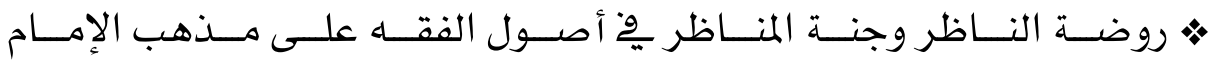
أحمد بن حنبل

للإمـام/ أبـي محهــ موفتق الـدين عبـد الله بـن أحهـد بـن محمهـ بـن قدامـة

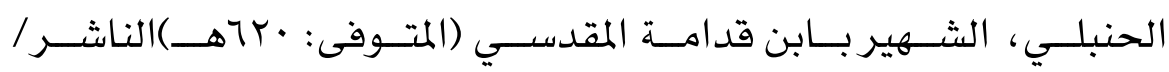

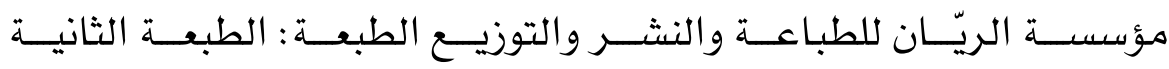

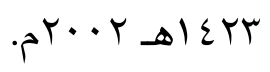




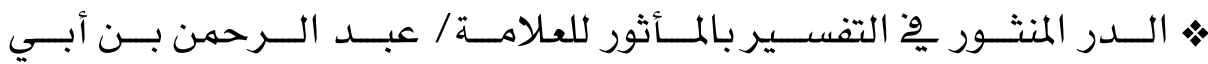

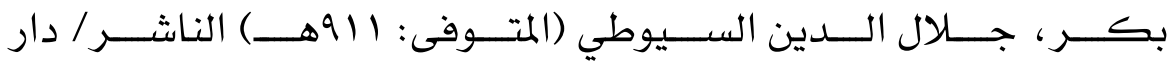

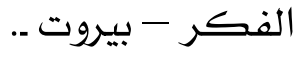

هــنـن أبـى داود : تـأليف الإمـام المصـنف أبـى داود سـليمان بـن الأشــثث

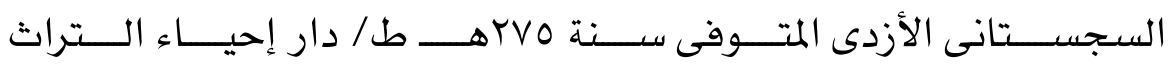

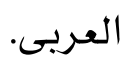

• ســن الـدارقطنى: لشـيخ الإســلام علـى بـن عمــر الـدار قطنـى، وبذيلـه

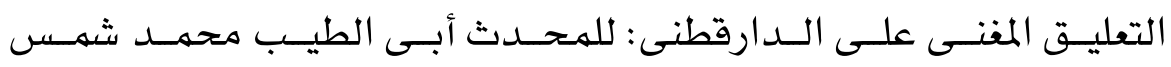
الحق العظيم آبادي ط/ عاله الكتاب.

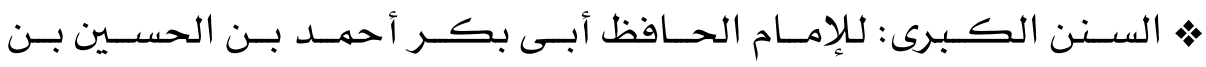
على البيهقى، طبعة/ دار المعرفة -بيروت - ط/ أولى بدون.

ه شـرح الســنة للإمـام أبـي محمــد الحســين بـن مســود بـن محمــد بـن

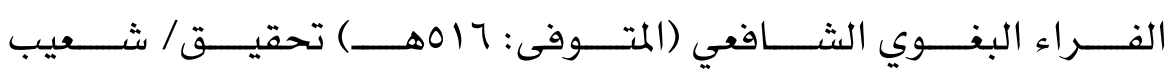

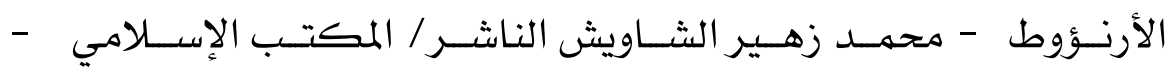
دمشق ، بيروت ـ الطبعة/ الثانية ب. ع اهـ بهول الم.

* شــرح تتقـيح الفصــول فـى إختصـــار المحصـــول فـى الأصــول: تــأليف الإمـام شـهاب الـدين أبـو العبـاس أحهــــــن إدريـس القرافـى تحقيـق /

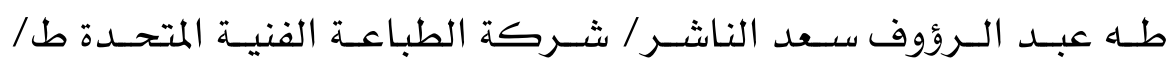

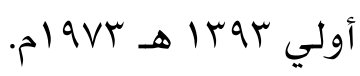


ثـ شـرح حـدود ابـن عرفـة للعـلامـة/ محمهـد بـن قاسـم الأنصـاري، أبـو عبـد

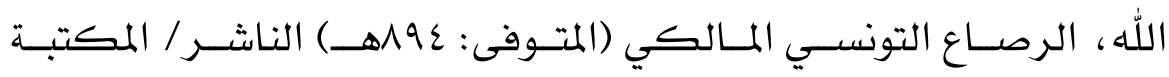

العلمية ط/ أولي •مس اهـ.

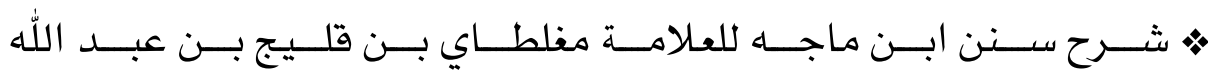

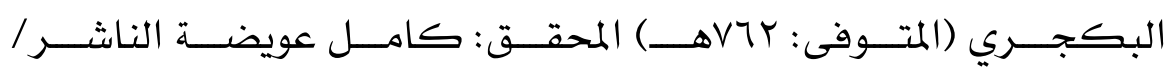

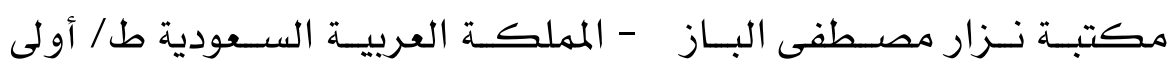
. 1999 1 1 1 19

هـ شـرح صـحيح البخــاري لابـن بطـال، أبـو الحسـن علـي بـن خلـف بـن عبــ

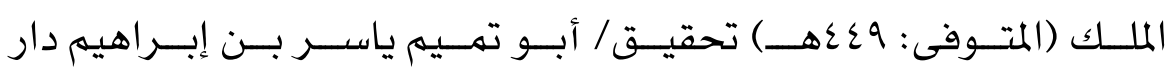

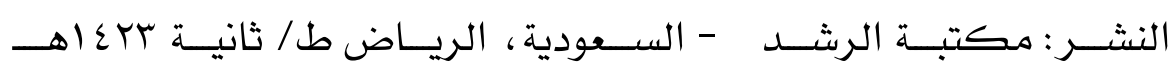

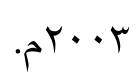

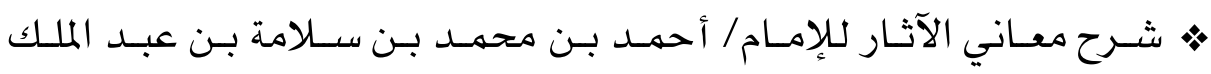

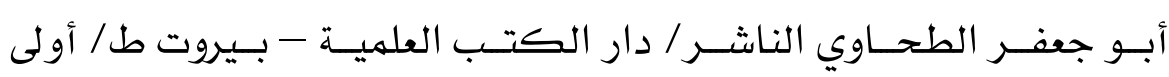
99 1 اهـ تحقيق/ موحمد زهـري النجار.

ه شـرح الكوكـب المـنير للإمــام/ تقــي الــدين أبــو البقــاء محمــد بـن

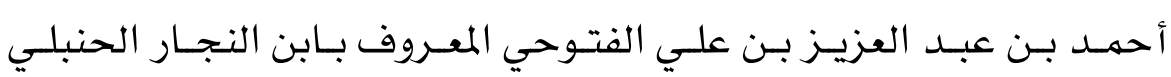

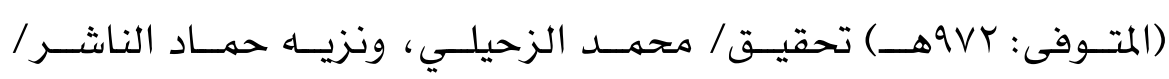

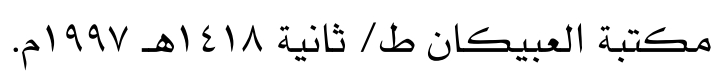




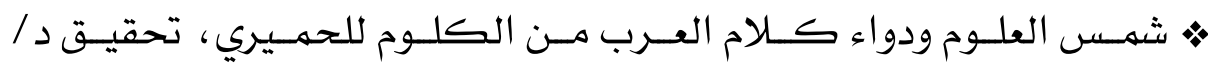

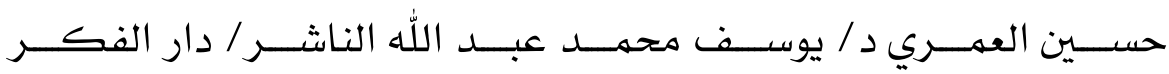
دمشق ط/ أولي ·rع اهـ 1999 ام.

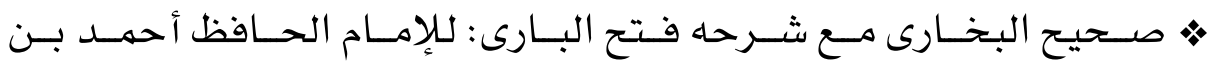

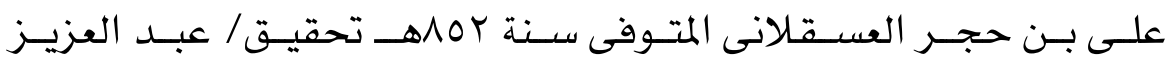
بـن عبـــد الله بـن بــاز ط/ دار الفكــر -بــيروت لبنــان - ، ط/ دار المعرفة، تحقيق/ محمد فؤاد عبد الباقى.

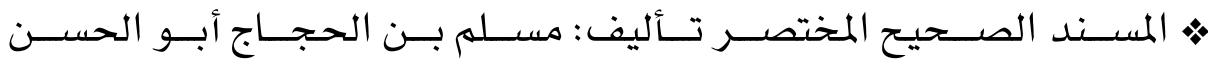
القشـيري النيســابوري (ت: البوهـ) المحقـق: محهـــ فـؤاد عبــد البـاقي الناشـر / دار إحياء التراث العربي - بيروت.

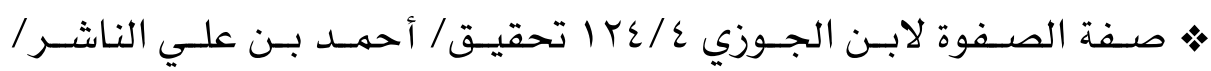

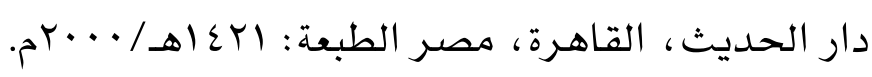

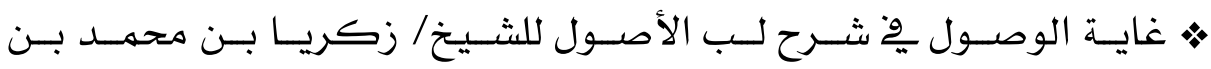
أحهــد بـن زكريــا الأنصـــاري، زيــن الــدين أبــو يحيـى الســنيكي

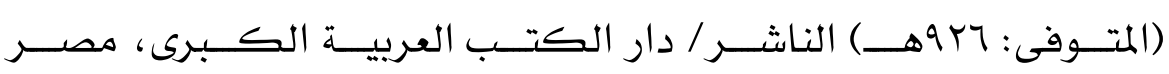
(أصحابها : مصطفى البابي الحلبي وأخويه).

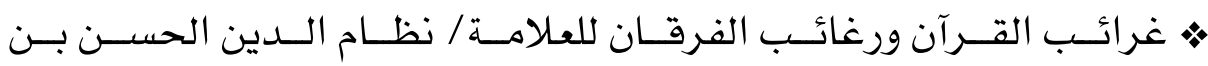

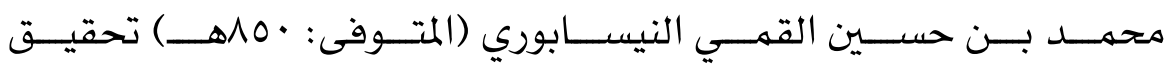




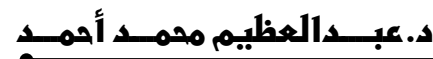

\section{تنقيح الاراء في حجيت الاستقراء سلا

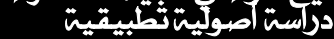

الثـيخ/ زكريـا عمـيرات الناشــر/ دار الكتـب العلميـهـ - بـيروت -

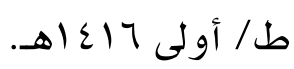

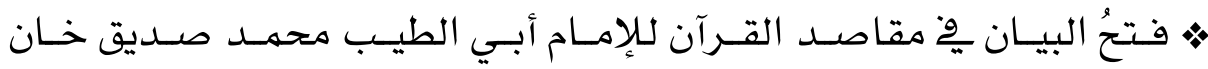

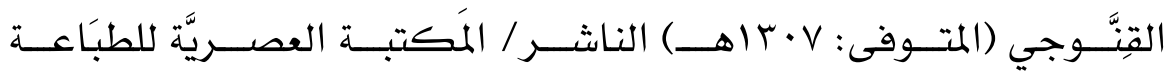

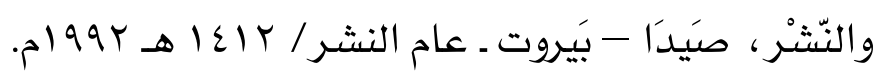

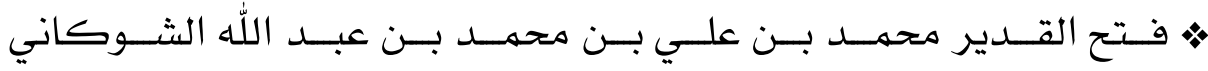

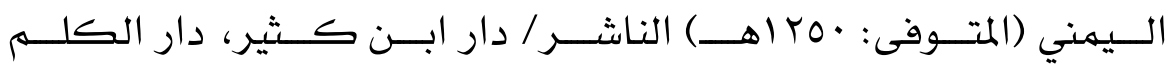

$$
\text { الطيب - دمشق، بيروت - }
$$

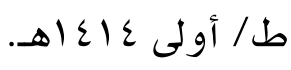

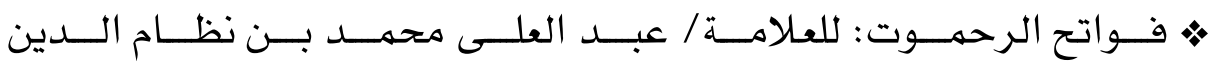

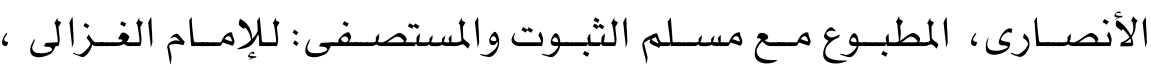
ط/ دار إحياء التراث العربى ط/ ثالثة ع اع اهـ - -.

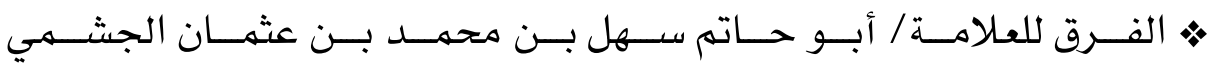

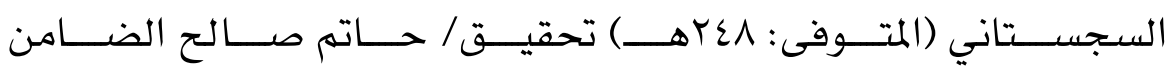

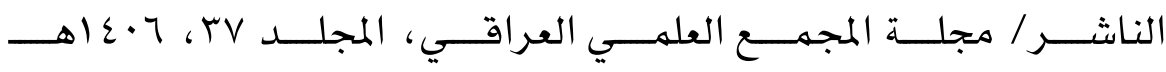
. 1917

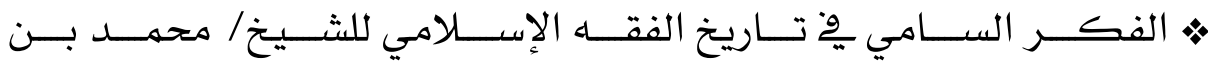

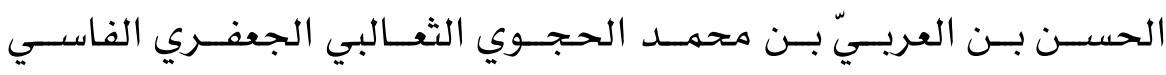




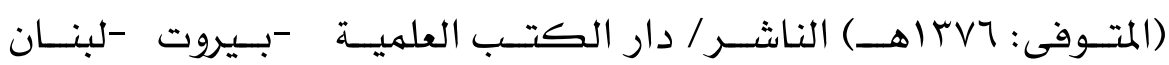

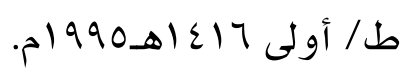

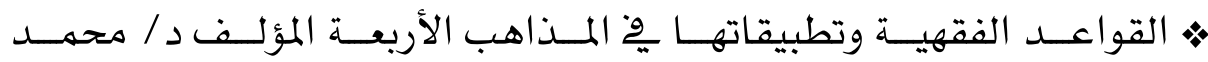
مصطفى الزحيلي.

عميــد كليــة الشــريعة والدراســات الإســلامية - جامعــة الثــارقة الناشر/ دار الفكر - دمشق

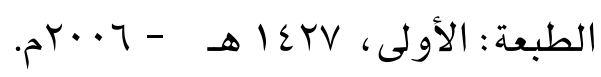

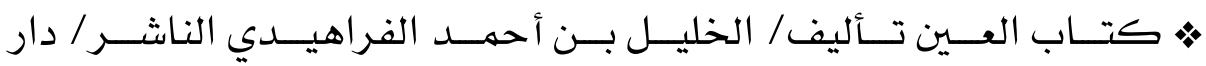

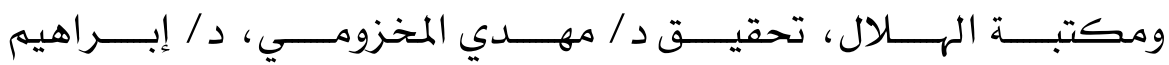
السـامر ائي.

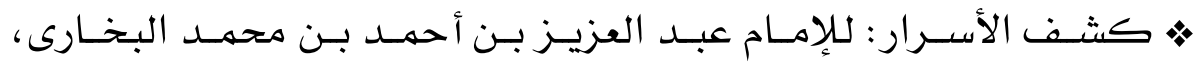
الناشـر / دار الكتاب الإسـلامي، بدون تاريخ.

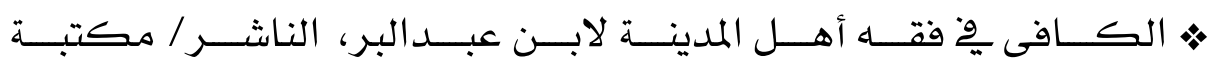

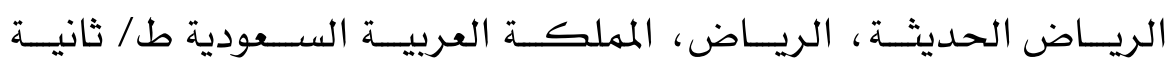

$$
\text { م } 9191 \cdot 2 \cdot
$$

ه لســان العـرب: تـأليف/ جمهـال الـدين محهـــ بـن مكـرم بـن منظـور

$$
\text { المصرى ط/ دار المعارف، لمان، }
$$

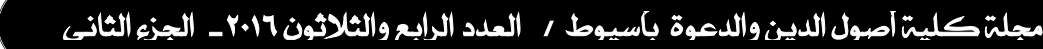




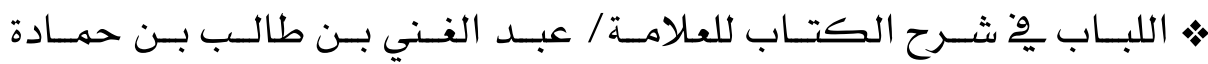

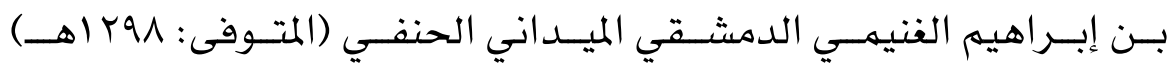
تحقيق/ محمد محيي الدين عبد الحميد الناشـر : المكتبة العلمية ، بيروت - لبنان ـ.

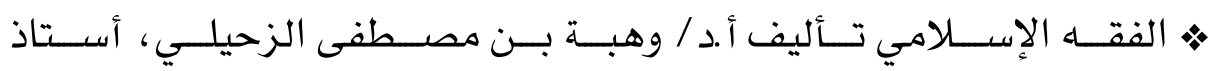

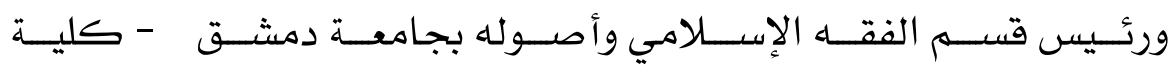
الشـريعة الناشر / دار الفكر - سورية - دمشق

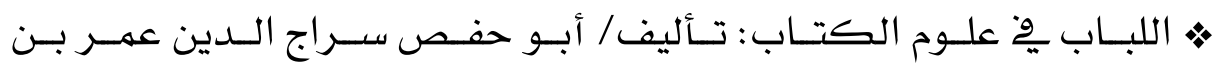

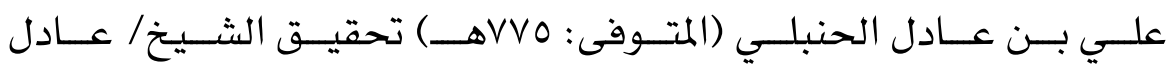

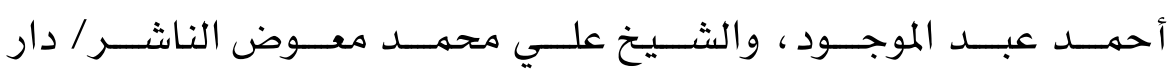
الكتــب العلميـــة - بــيروت / لبنـــان الطبعــــة: الأولى، 19 . 1991

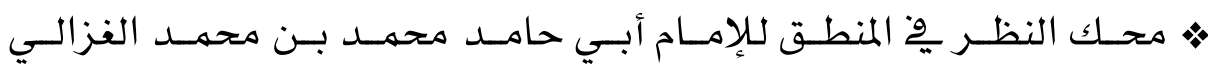

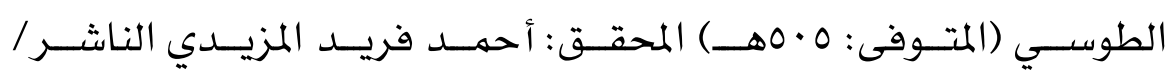
دار الكتب العلمية ، بيروت - لبنان ـ.

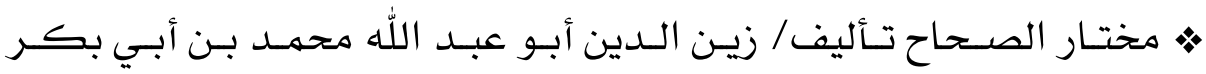

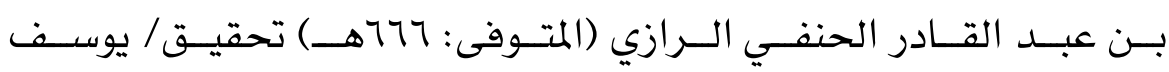
الشــيخ محمـــد الناشـــر/ المكتبــة العصـــرية - بـيروت - صــيدا،

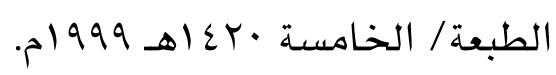




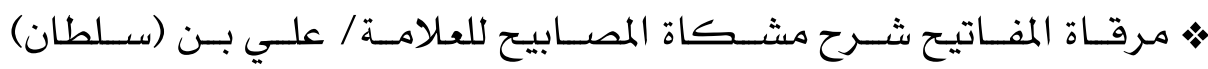
محهـــد ، أبــو الحســن نــور الــدين المــلا الهــروي القــاري (المتــوفى:

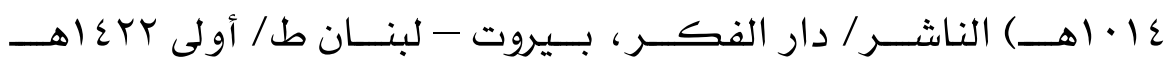

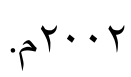

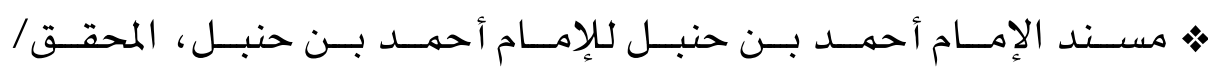

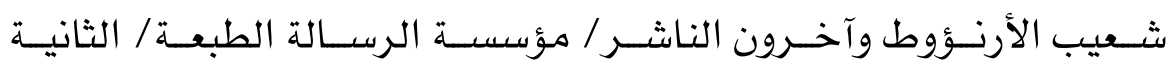

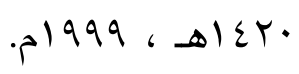

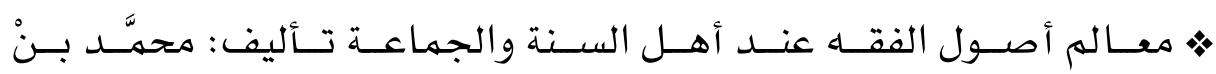

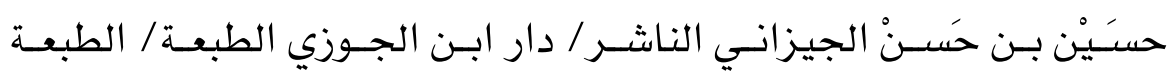

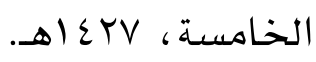

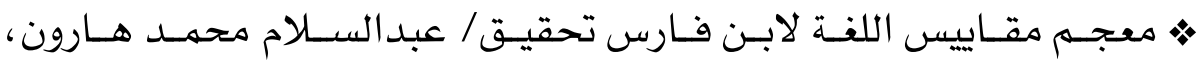

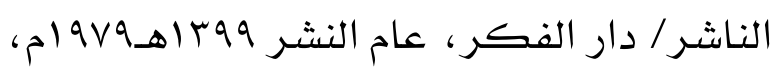

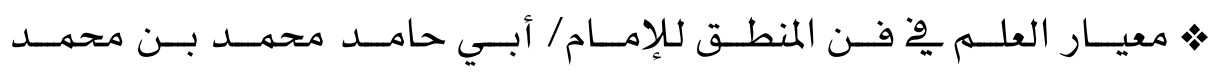

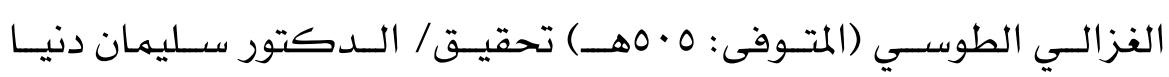
الناشر / دار المعارف، مصر عام النشر/ / 1971 م.

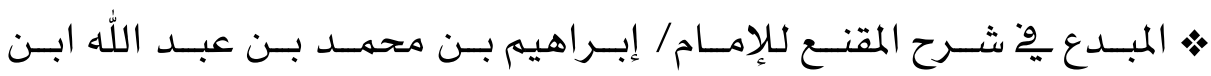

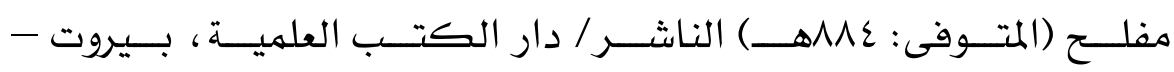
لبنان ط/ أولى 11 اع أهـ 


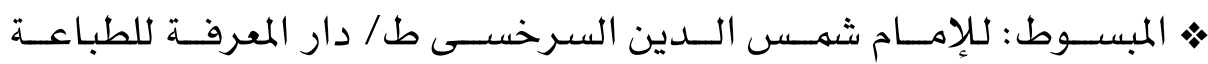

$$
\text { والنشر -بيروت }
$$

$$
\text { لبنان - ط/ ثانية عاعاهـ - } 1994 \text { ام. }
$$

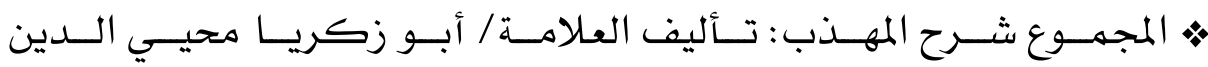
يحيى بن شرف النووي (المتوفى: 7V7هـ) الناشـر : دار الفكر.

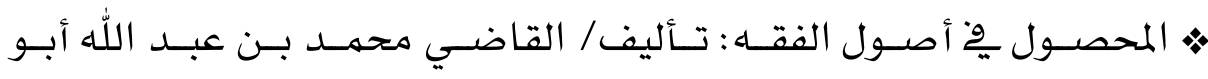

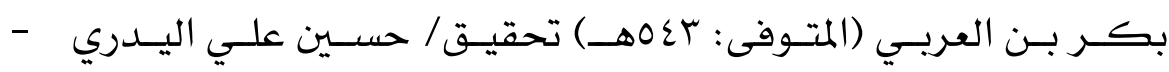

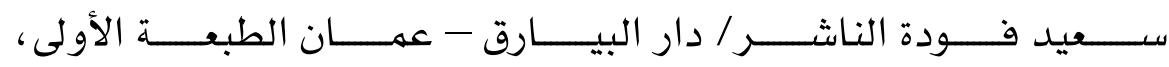

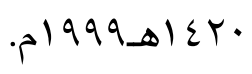

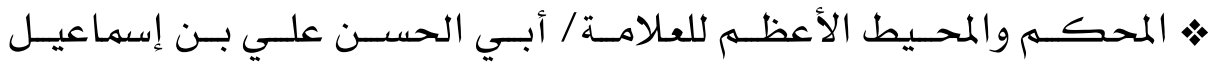

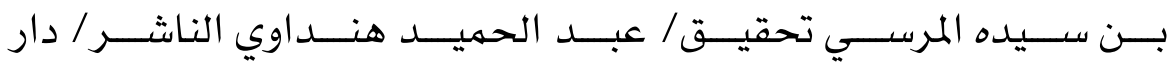

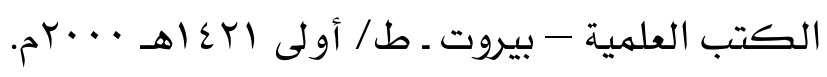

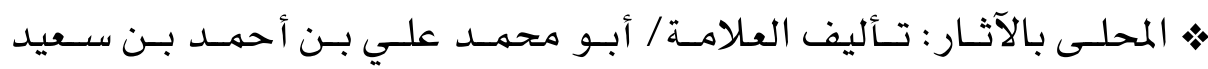

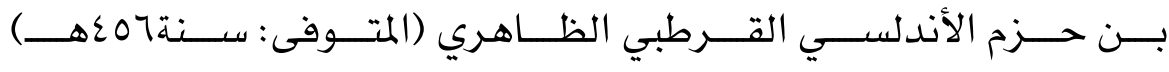

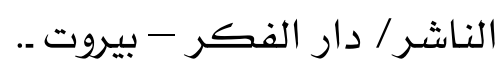

هـ المخصـص للعلامسة / أبـي الحسـن علـي بـن إسماعيـل بـن سـيده المرسـي

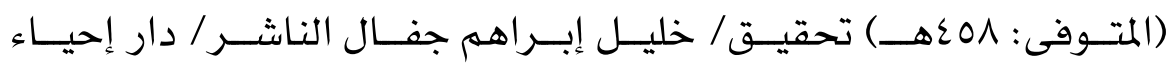

$$
\text { التراث العربي - بيروت }
$$




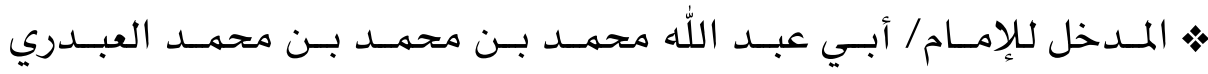

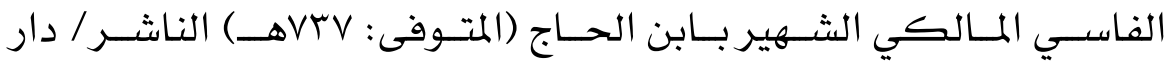
التراث، بدون تاريخ.

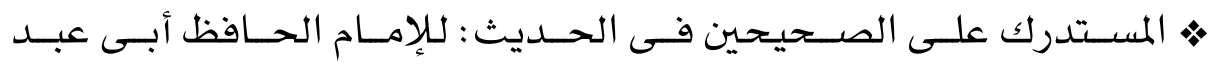

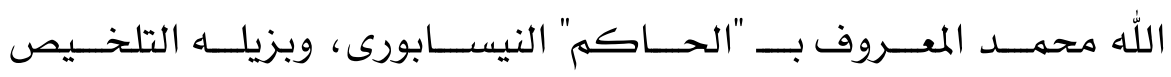
للحافظ الذهبى ط/دار المعرفة - لمروف

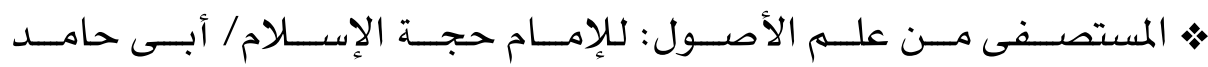

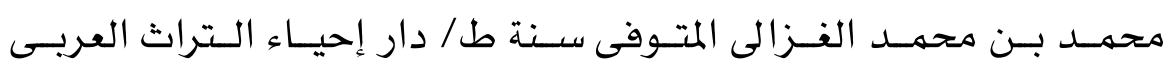

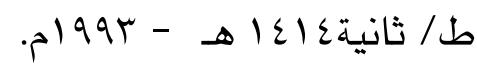

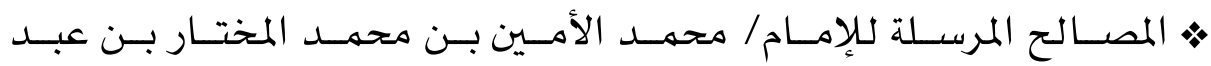

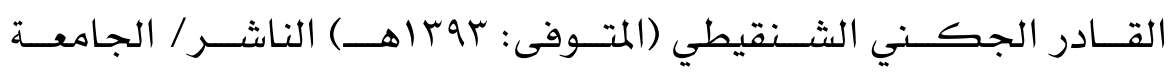
الإسـلامية ، المدينة المنورة

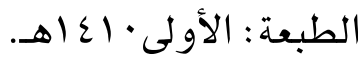

ه المصـباح المـنير مْ غريـب الثـرح الكـبير للإمـام/ أحمـد بـن محمـد بـن

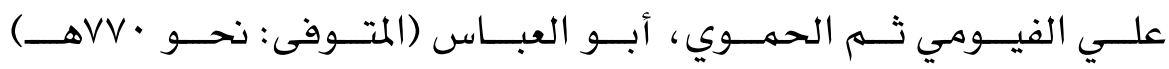
الناشر / المكتبة العلمية - بيروت .. 


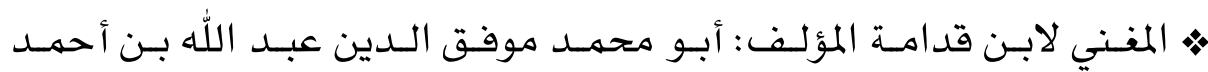

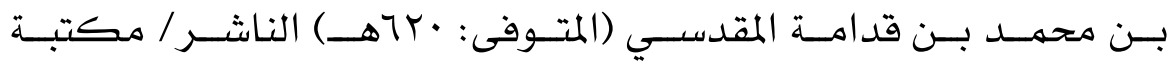

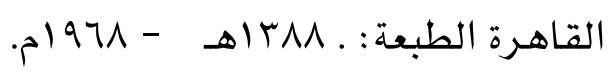

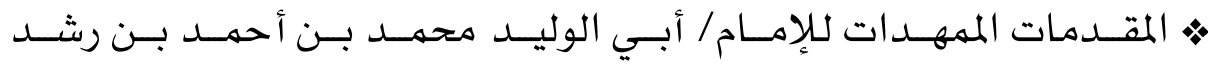

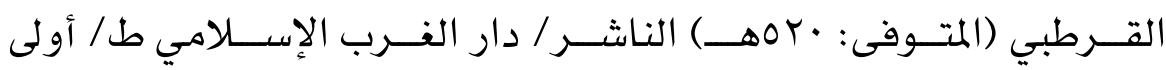

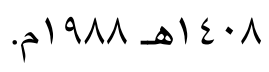

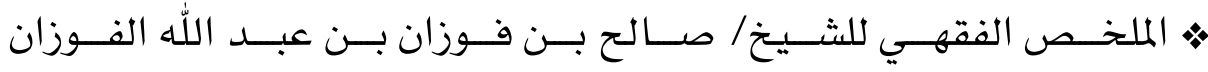

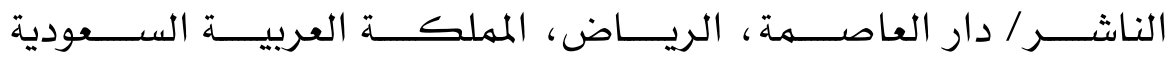

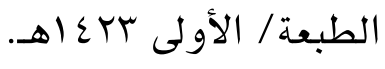

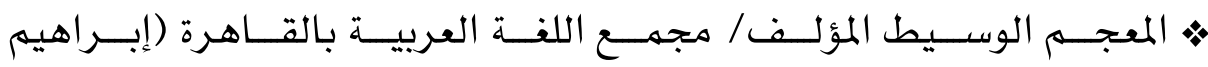
مصــطف / أحهــد الزيــات / حامــد عبــد القــادر / محهـــ النجــار) الناشرم دار الدعوة.

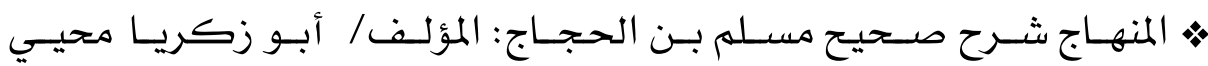

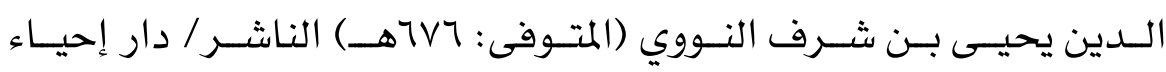

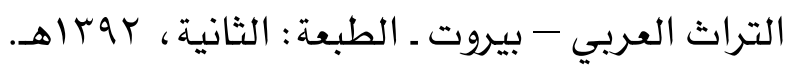

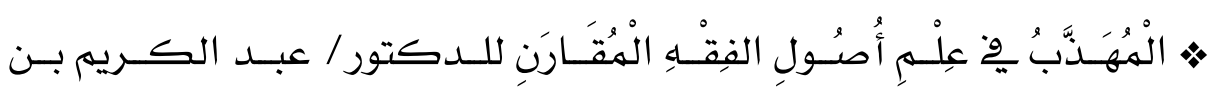

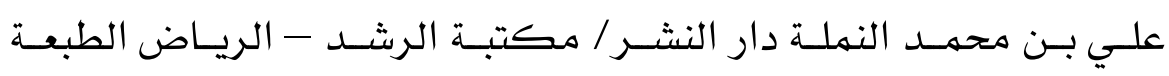

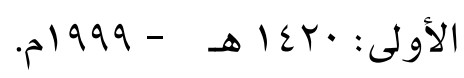

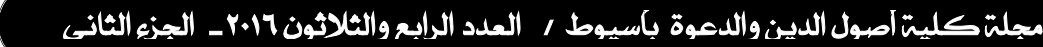




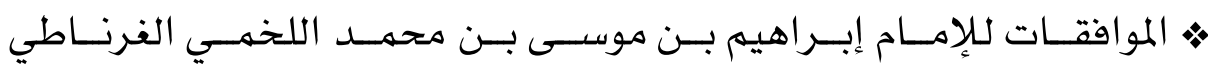

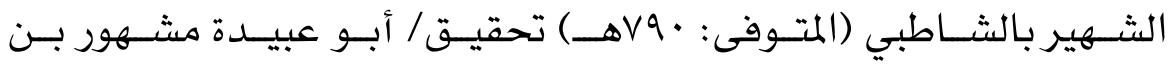

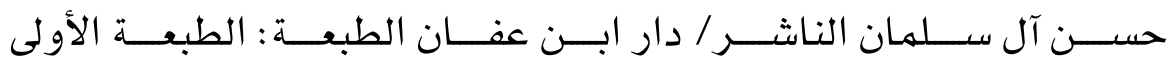

$$
\text { 199V أهـ IV }
$$

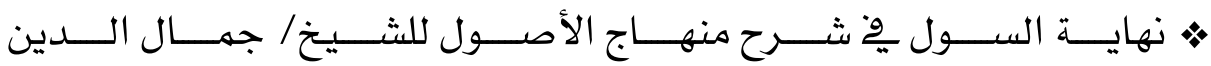

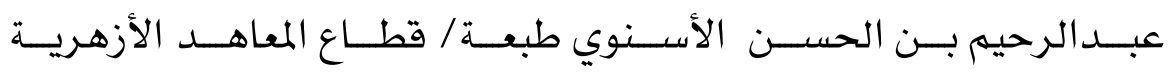

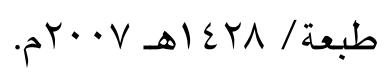

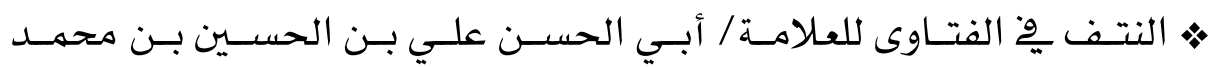

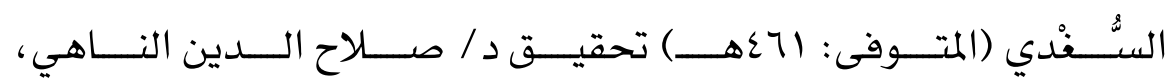
النـاشــر / دار الفرقونـان / مؤسســة الرســالة - عمــان الأردن / بــيروت لبنان ط/ ثانية ع ·ع اهـ عه19 ام. 
1914

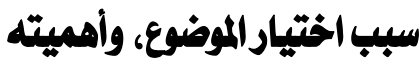

$191 \varepsilon$ الأول: تعريف الاستقرائ لغة واصطلاحاً.

1910 المطالب الأول : تعريـف الاستقراي لغتٌ

$191 V$ الهمانب 11نانـي : تعريف الاستقراء اصطلاحما

19ro الثاني: أقسام الاستقرايه وحكمه .

1940 تمهبي للموضو ع :

$19 p q$ 1المطاب الآول : الاستقراء التام وحصكه

I $9 Y V$ حصكم الاستقراء التام

$19 \%$ بيان الراي الراجح وسبب الترجيح

$19 \mu$ 1الهب 11نْانبي: الاستقراء الناقص وحكمه

$19+\varepsilon$ تعريف الاستقراء الناقص

$19 \mu \mathrm{V}$ حكبم الاستقراء الناقص . $19 \% 1$ أقوال العلماء وأدلتهم والمناقشت والترجيع . 


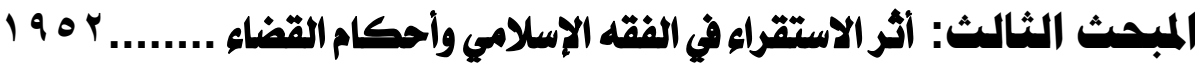

$190 \%$ المطلب 1الأول: أثر الاستقراء في الفقه الإسلامي.

190r الفر ع الأول: أثر الاستقراء في أقل الحيض وأكثره

191. بيان الراي الراجح وسبب الترجيح:..

$19 \wedge r$ الفر ع الثانيي: أثر الاستقراء في أقل النفاس وأكثره

1991 بيان الراي الراجح وسبب الترجيح:

$199 \leq$ الفر ع الثالث: حكمرصلاة الوتر

$r .11$ بيان الراي الراجع وسبب الترجيح:..

$r+1 \varepsilon$ المطلب الثناني: أثر الاستقراء في أحكام القضاء.

$r+10$ الفر ع الأول : أثر الاستقراء في أحصكام الأسرة

$r+19$ الفر ع الثانـي: أثر الاستقراء في الأحكام الإداريت

$r+11$ الفر ع الثالث: أثر الاستقراء في الأحكام الجنائيت

$r \cdot r 1$ الخاتمة وأهم نتائج البحث.

$r \cdot r \varepsilon$ الفهـــارسه. $r \cdot r \varepsilon$ أولأ: ثهرس أهم الإسادروالمراجع حسبب الترتيب الأبجدي. 
